Portland State University

PDXScholar

$1-1-2011$

\title{
CE-QUAL-W2 Water Quality and Fish-bioenergetics Model of Chester Morse Lake and the Cedar River
}

Vanessa I. Wells

Portland State University

Follow this and additional works at: https://pdxscholar.library.pdx.edu/open_access_etds

Let us know how access to this document benefits you.

\section{Recommended Citation}

Wells, Vanessa I., "CE-QUAL-W2 Water Quality and Fish-bioenergetics Model of Chester Morse Lake and the Cedar River" (2011). Dissertations and Theses. Paper 324.

https://doi.org/10.15760/etd.324

This Thesis is brought to you for free and open access. It has been accepted for inclusion in Dissertations and Theses by an authorized administrator of PDXScholar. Please contact us if we can make this document more accessible: pdxscholar@pdx.edu. 


\title{
CE-QUAL-W2 Water Quality and Fish-bioenergetics Model of Chester Morse Lake and the Cedar River
}

\author{
by \\ Vanessa I. Wells \\ A thesis submitted in partial fulfillment of the \\ requirements for the degree of \\ Master of Science \\ in \\ Civil and Environmental Engineering
}

Thesis Committee:

Scott Wells, Chair Mark Sytsma

Chris Berger

Portland State University

2012 


\begin{abstract}
Many communities are currently seeking to balance urban water needs with preservation of sensitive fish habitat. As part of that effort, CE-QUAL-W2, a hydrodynamic and temperature model, was developed for Chester Morse Lake and the lower Cedar River, WA. Chester Morse Lake is approximately $10 \mathrm{~km}$ long with a maximum depth at full pool of $40 \mathrm{~m}$. The Cedar River model started immediately downstream of the Chester Morse dam and ended $21 \mathrm{~km}$ downstream at Landsburg, where drinking water is diverted for the City of Seattle. This water quality model was coupled with a fish habitat and bioenergetics model for bull trout and was calibrated to temperature data between 2005 and 2008. Bull trout fish bioenergetics parameters were provided by the USGS. The CE-QUAL-W2 model was found to be highly accurate in modeling temperature variation in the lake - at most locations having an average absolute mean error of between 0.5 and $0.8{ }^{\circ} \mathrm{C}$. The Cedar River model had an average absolute mean error of $0.7^{\circ} \mathrm{C}$. This tool is designed to allow managers and operators to estimate the impact to fish habitat and growth potential from various management decisions including extent of drawdown, timing/volume of flows, and various pumping operations. Future studies could include incorporating further water quality parameters such as nutrients, algae, and zooplankton as they relate to fish productivity.
\end{abstract}




\section{Acknowledgments}

Special thanks to Dwayne Paige and Heidy Barnett from Seattle Public Utilities for providing bathymetric, meteorological and biological data and expertise.

Thanks also to Dave Beauchamp and Matt Mesa from USGS for providing fish bioenergetics parameters. 


\section{Table of Contents}

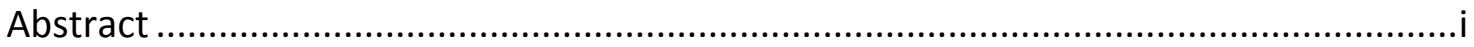

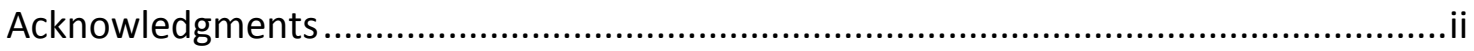

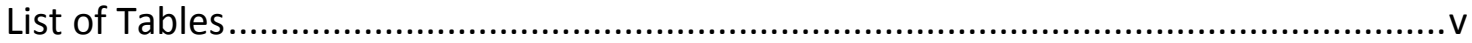

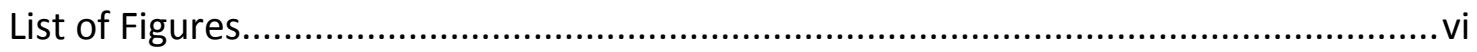

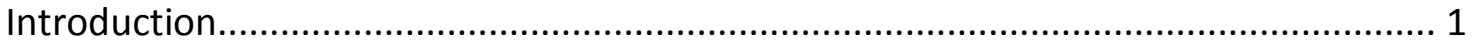

CE-QUAL-W2

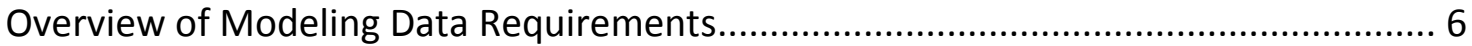

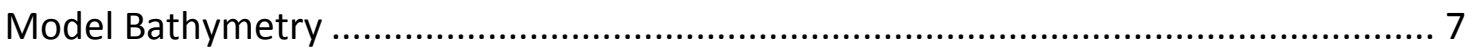

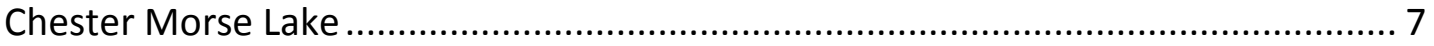

Cedar River below Chester Morse Lake .............................................................. 13

Connecting Chester Morse Lake and the Cedar River Models ............................... 19

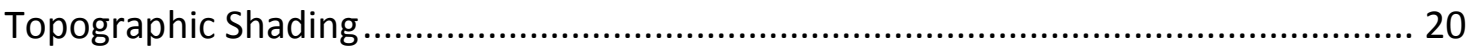

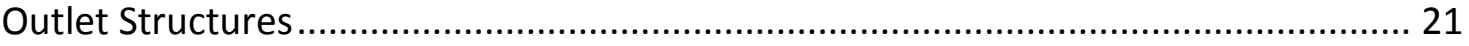

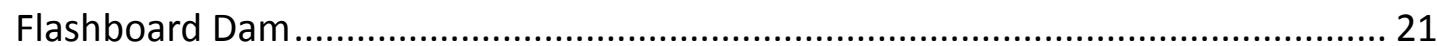

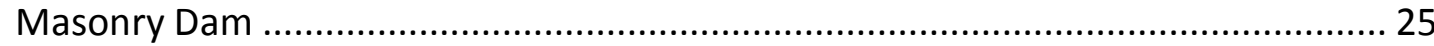

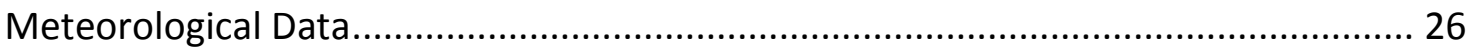

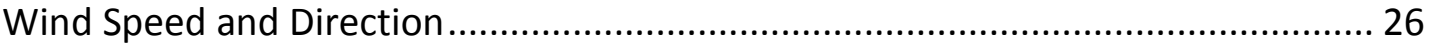

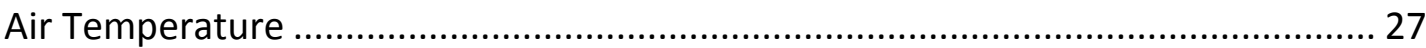

Dew Point Temperature and Relative Humidity ............................................... 28

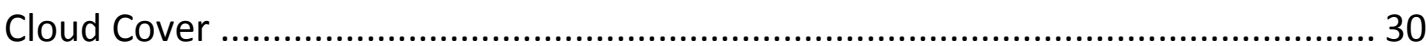

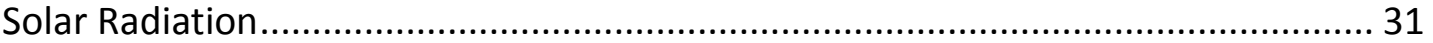

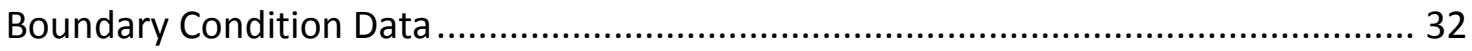

Chester Morse Lake Model Boundary Conditions ............................................... 32

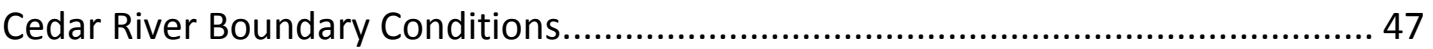

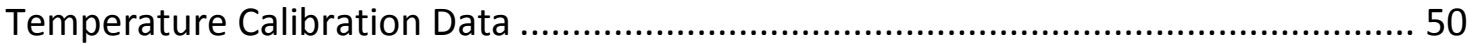

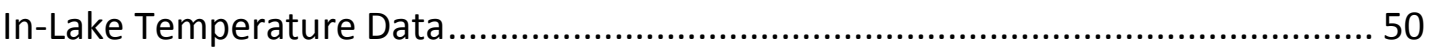

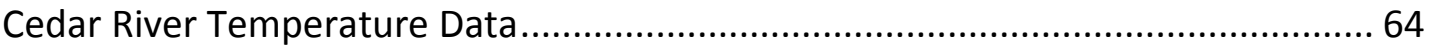




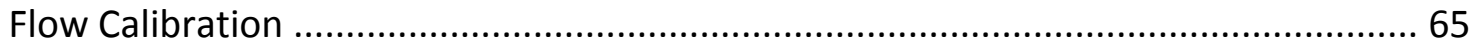

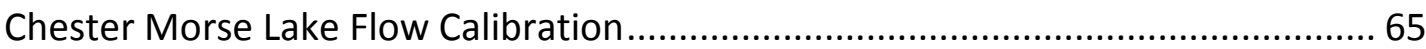

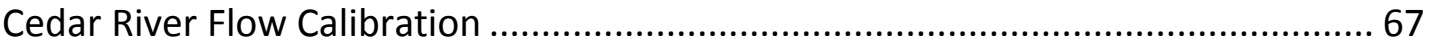

Temperature Calibration and Final Temperature Results ..........................................69

Chester Morse Lake Temperature Calibration ........................................................... 69

Chester Morse Lake Final Temperature Results................................................... 78

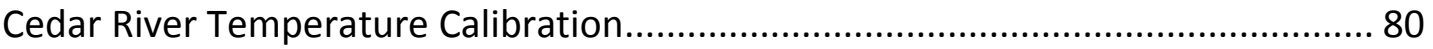

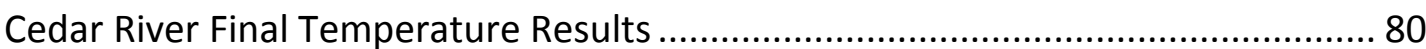

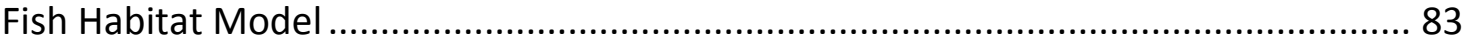

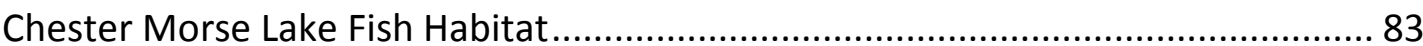

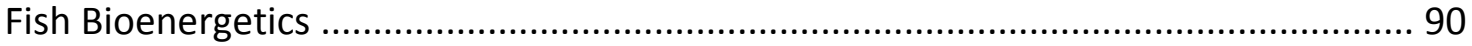

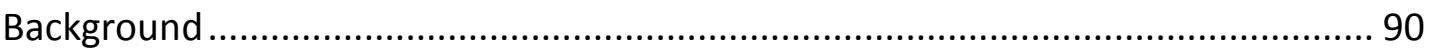

Application to Chester Morse Lake Model ............................................................. 91

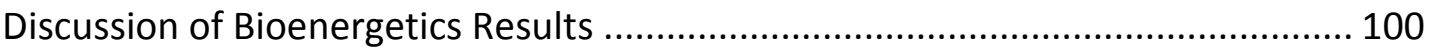

Summary and Conclusions .................................................................................. 102

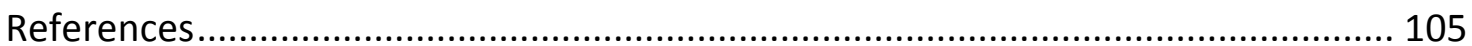

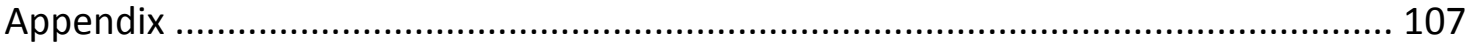

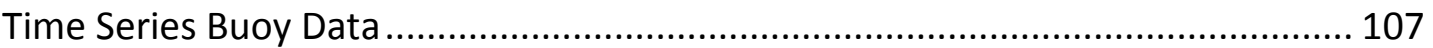

Manually Collected Temperature Profile Data.................................................... 136 


\section{List of Tables}

Table 1. Data needs for modeling the reservoir and river system (Berger and Wells, 2011)

Table 2. Chester Morse Lake model grid details.......................................................... 9

Table 3. Chester Morse Lake model branch details...................................................... 9

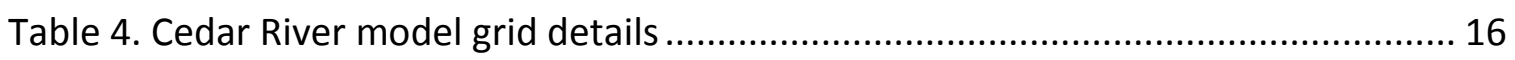

Table 5. Cedar River model branch details .................................................................. 16

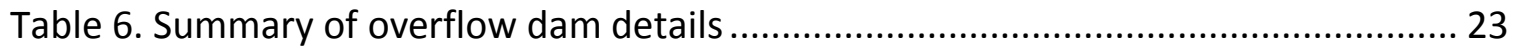

Table 7. Summary details for underflow gates .......................................................... 24

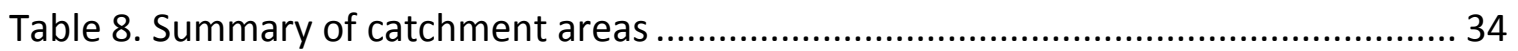

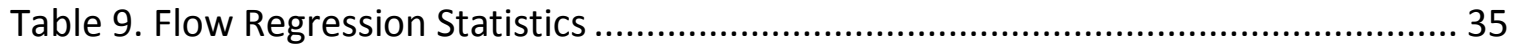

Table 10. Summary of area based regression to calculate minor tributary inflows to Chester Morse Lake ................................................................................................. 35

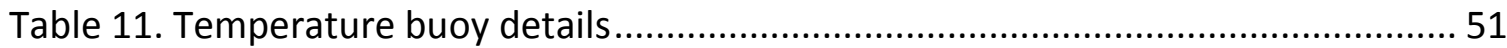

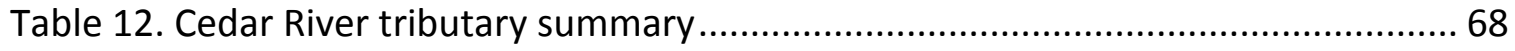

Table 13. Chester Morse Lake model time-series temperature error statistics .............. 78

Table 14. Chester Morse Lake model temperature profile error statistics ..................... 79

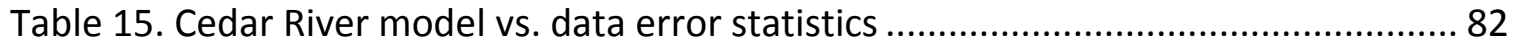

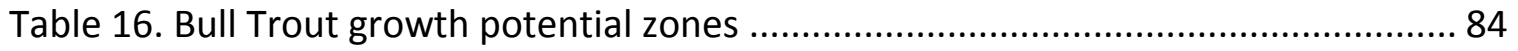

Table 17. Bioenergetics parameters (McKillip and Wells, 2007) ................................... 91

Table 18. Digestion parameter variables (McKillip and Wells, 2007) .............................. 93

Table 19. Consumption parameter variables, (McKillip and Wells, 2007) ...................... 94

Table 20. Respiration parameter variables (McKillip and Wells, 2007) .......................... 95

Table 21. Bull trout consumption parameters (Matt Mesa et al., 2011) ........................ 96 


\section{List of Figures}

Figure 1. Location map of Chester Morse Lake and the Cedar River .............................. 2

Figure 2. Original bathymetry data for Chester Morse Lake (SPU) ................................. 7

Figure 3. 3-D elevation map of Chester Morse Lake and surroundings ............................ 8

Figure 4. Chester Morse Lake Model branches, segments........................................... 8

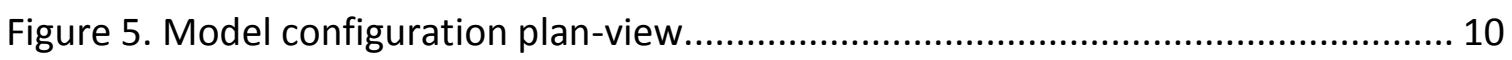

Figure 6. Model configuration side-view ................................................................ 10

Figure 7. Vertical model segment slices: left segment 2, middle segment 33 and right model segment 63 (Masonry Pool)........................................................................... 11

Figure 8. Chester Morse Lake volume-elevation curve ................................................... 12

Figure 9. Chester Morse Lake surface area-elevation curve ........................................ 12

Figure 10. Cedar River transect data (in red) and USGS DEM coverage of surrounding

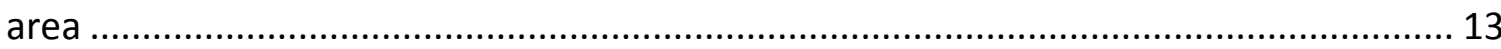

Figure 11. 3-D elevation map of Cedar River and surroundings.................................... 14

Figure 12. Cedar River Model branches, segments ................................................... 14

Figure 13. Centerline elevation and slope - branches 1,2 , and 3 ................................ 15

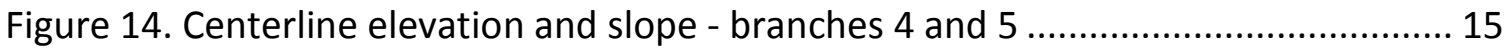

Figure 15. Plan view of Cedar River model segments ................................................. 17

Figure 16. Side view of Cedar River model segments.................................................. 17

Figure 17. Cross-sectional view of Cedar River model segment 9 .................................. 18

Figure 18. Full system map - Chester Morse Lake and Cedar River model connectivity . 19

Figure 19. Topographic shading diagram (CE-QUAL-W2 User Manual) .......................... 20

Figure 20. Schematic of flashboard dam (Paige, 2009) ................................................ 21

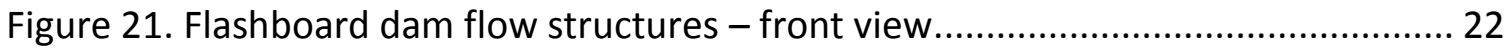

Figure 22. Schematic of Masonry Dam, Masonry Pool, and Overflow Dike (Paige, 2009)

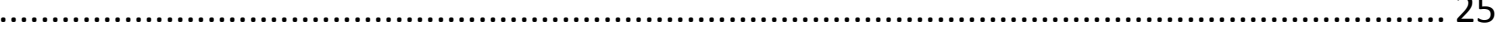

Figure 23. Chester Morse Lake wind rose (USGS 122115900) (Bing, Inc. 2009) ............. 26

Figure 24. Chester Morse Lake air temperature (USGS 122115900) ............................ 27

Figure 25. Map of met station locations (Google Inc., 2009) ........................................... 28

Figure 26. Dew point temperatures calculated using Renton (KRNT) and Stampede Pass

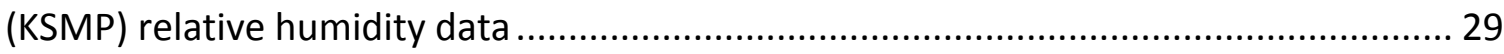

Figure 27. Renton (KRNT) and Stampede Pass (KSPM) cloud cover data........................ 30

Figure 28. Chester Morse Lake catchment basin.......................................................... 32

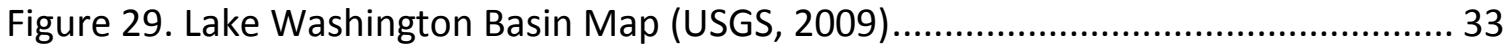

Figure 30. Gaged inflows into Chester Morse Lake (model years 1 and 2) ..................... 37

Figure 31. Gaged inflows into Chester Morse Lake (model years 3 and 4) ................... 38 
Figure 32. Cedar River water temperature (USGS 12115000)...................................... 39

Figure 33. Boulder Creek - Cedar River temperature regression.................................... 40

Figure 34. Rex River - Cedar River temperature regression ..................................... 41

Figure 35. Rack Creek - Cedar River temperature regression ........................................ 42

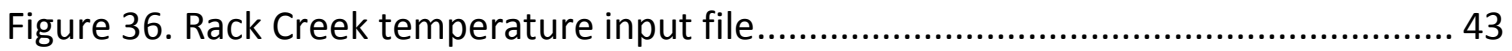

Figure 37. Stream discharge downstream of Chester Morse Lake over model period.... 44

Figure 38. Lake Washington Basin schematic (USGS, 2009) ........................................ 45

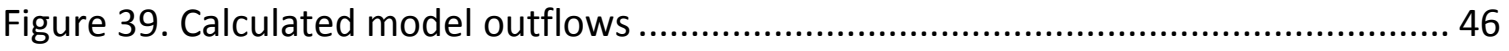

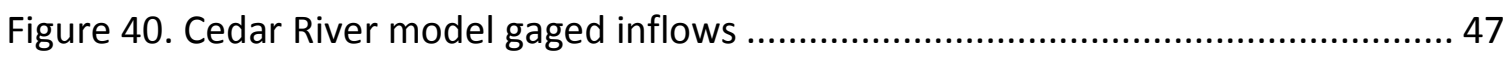

Figure 41. Chester Morse Lake model Masonry Dam outflow temperatures................. 48

Figure 42. Location of temperature probes, buoys 1-7 (Paige, 2009) ............................ 51

Figure 43. Time series temperature data collected at Buoy 1 (corresponding to model segment 9)

Figure 44. Time series temperature data collected at Buoy 2 (corresponding to model segment 17)

Figure 45. Time series temperature data collected at Buoy 3 (corresponding to model segment 47)

Figure 46. Time series temperature data collected at Buoy 4 (corresponding to model segment 13)

Figure 47. Time series temperature data collected at Buoy 5 (corresponding to model segment 23)

Figure 48. Time series temperature data collected at Buoy 6 (corresponding to model segment 34)

Figure 49. Time series temperature data collected at Buoy 7 (corresponding to model segment 64) - Masonry Pool ....................................................................................... 58

Figure 50. Temperature profiles collected at center of Chester Morse Lake, 2005....... 59

Figure 51. Temperature profiles collected at center of Chester Morse Lake, 2006........ 60

Figure 52. Temperature profiles collected at center of Chester Morse Lake, 2007........ 61

Figure 53. Temperature profiles collected at center of Chester Morse Lake, 2008....... 62

Figure 54. Temperature profiles collected in Masonry Pool near Masonry Dam, 2005-08

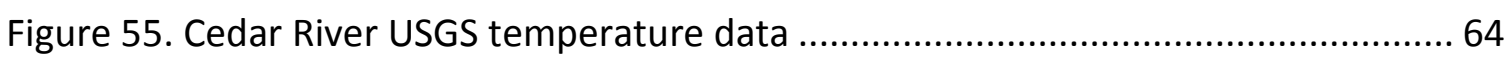

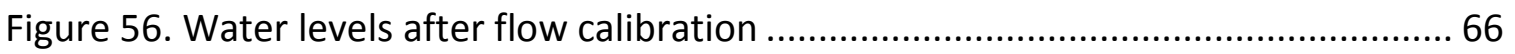

Figure 57. Comparison of water balance flows to seepage loss equation ..................... 67

Figure 58. Cedar River flow calibration results ......................................................... 68

Figure 59. Wind sheltering coefficient for model segments 2 and 20 .......................... 70 
Figure 60. Cedar River confluence - highlighting Cedar River inflow temperature issue 71 Figure 61. Mid-lake temperature profiles - highlighting Cedar River mid-summer 2008 inflow temperature issue

Figure 62. Model data comparison at buoy 7, depth 20 meters - no cold water spring inflow

Figure 63. Model data comparison at buoy 7, depth 20 meters - cold water spring inflow 73

Figure 64. Model data comparison at buoy 7 - pre-calibration ..................................... 75 Figure 65. Model data comparison at buoy 7 - post-calibrationFigure 66 and Figure 67 show pre- and post-calibration model data comparisons at segment 47 (buoy 3)........ 75 Figure 66. Model data comparison at buoy 3 - pre-calibration ..................................... 76 Figure 67. Model data comparison at buoy 3 - post-calibration ................................... 76 Figure 68. Model data temperature profile comparisons at mid-lake - pre-calibration 77 Figure 69. Model data temperature profile comparisons at mid-lake - post-calibration 77 Figure 70. Cedar River model data comparison at location corresponding to model segment 16

Figure 71. Cedar River model data comparison at location corresponding to model

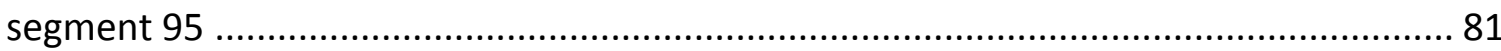

Figure 72. Photograph of bull trout (OutsmartingFish.com (2009)) ............................. 83

Figure 73. Bull trout growth potential curve from Selong et al. (2001) ......................... 84

Figure 74. Fish Habitat volumes for Bull Trout in Chester Morse Main Lake - (2005-2006)

Figure 75. Fish Habitat volumes for Bull Trout in Chester Morse Main Lake - (2007-2008)

Figure 76. Fish Habitat volumes for Bull Trout in Chester Morse Masonry Pool - (20052006)

Figure 77. Fish Habitat volumes for Bull Trout in Chester Morse Masonry Pool - (20072008)

Figure 78. Fish bioenergetics growth results with fixed mass at model segments 23 and 64

Figure 79. Fish bioenergetics growth results with model calculated mass at model

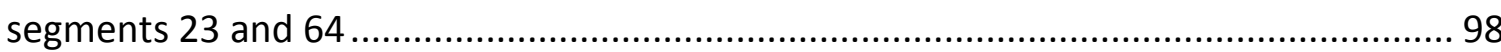

Figure 80 . Fish bioenergetics mass results at model segments 23 and 64 ................... 99 


\section{Introduction}

Chester Morse Lake, located in central western Washington, is a key source of drinking water for the city of Seattle. The lake and its tributaries are also home to native bull trout, a species currently listed as "threatened" under the Endangered Species Act. The purpose of this Master's Thesis is to develop a tool that will enable this resource to be managed in a balanced and sustainable way for both human needs and the needs of sensitive biological communities present in the lake and river system.

The Chester Morse Lake watershed, which measures approximately 91,400 acres, has provided drinking water to the City of Seattle for over 100 years. Figure 1 shows the location of the Chester Morse Lake watershed. Original lake levels were at approximately 1530 feet $(466.3 \mathrm{~m})$, but were raised in 1900 to 1560 feet $(475.5 \mathrm{~m})$ by the building of a dam on the Cedar River (Stein, 2000). The lake is approximately 6 miles $(10 \mathrm{~km})$ long with an average surface area of 1500 acres $\left(6,000,000 \mathrm{~m}^{2}\right)$. The lake has a maximum depth at full pool of 130 feet (40 m) (Paige, 2009). 


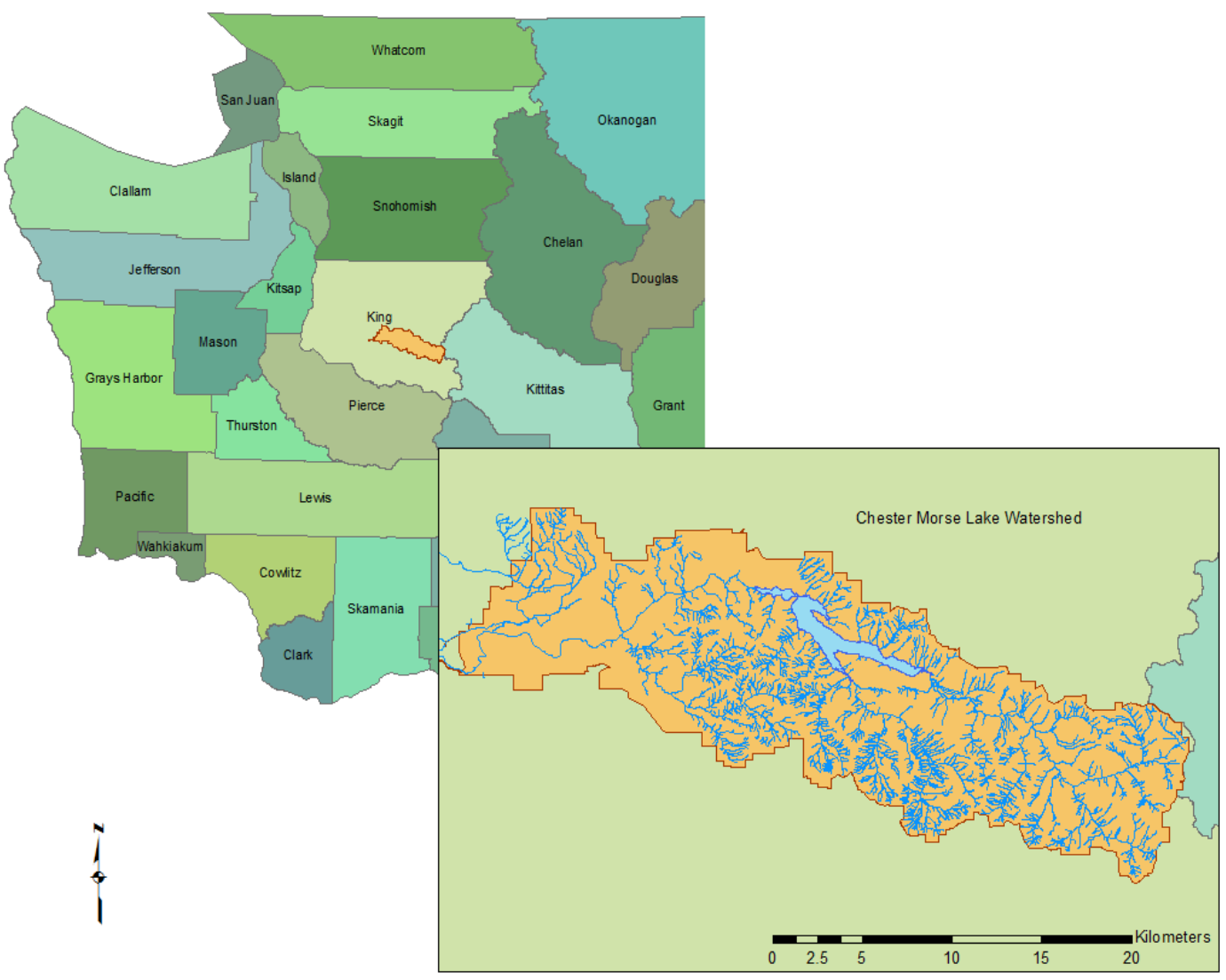

Figure 1. Location map of Chester Morse Lake and the Cedar River

The Chester Morse Lake watershed was heavily logged from 1900 until the 1960s, when landowners signed the Cedar River Watershed Cooperative Agreement. This agreement gradually transferred land ownership to the City of Seattle. One final piece of the watershed was ceded to the City by the USDA Forest Service in 1996, which gave the City of Seattle complete ownership of the watershed (Stein, 2000). Chester Morse Lake is now operated by Seattle Public Utilities, a subsidiary of the City of Seattle.

Several unique features set this system apart from many other lake systems. The first feature is the presence of a flashboard dam which divides the lake into two sections - 
the Main Lake, and the Masonry Pool. The Masonry pool is a much smaller section that is regularly drawn down considerably below the level of the main lake during the late summer period. This intermediate dam creates an additional level of hydrodynamic complexity to the lake model. A second unique feature of this system is the presence of a glacial moraine abutting the Masonry Pool. This moraine is highly permeable and results in significant seepage loss from the Masonry Pool. A portion of this water eventually flows back into the Cedar River some distance downstream as groundwater inflows. 


\section{CE-QUAL-W2}

CE-QUAL-W2 version 3.7 was used for this model application. This version includes newly introduced fish habitat routines that were used in this study (Cole and Wells, 2011). The User Manual for model 3.7 is available for download from http://www.cee.pdx.edu/w2/.

The follow model description is adapted from Berger and Wells (2011):

The model used for the Chester Morse Lake is the public domain model, CEQUAL-W2 (Cole and Wells, 2010). This model is a 2-dimensional (longitudinalvertical) hydrodynamic and water quality model capable of predicting water surface elevation, velocity, temperature and many other water quality parameters. The model is set up to predict these state variables at longitudinal segments and vertical layers.

Typical model longitudinal resolution is between $100-1000 \mathrm{~m}$; vertical resolution is usually between $0.5 \mathrm{~m}$ and $2 \mathrm{~m}$. The model can also be used in quasi-3-D mode, where embayments are treated as separate model branches off the main stem of the reservoir. The user manual and documentation can be found at the PSU website for the model: http://www.cee.pdx.edu/w2.

Dr. Wells and his group have been the primary developers of this model for the ERDC (Engineer Research and Development Center), Environmental Laboratory, Waterways Experiments Station Corps of Engineers for the last 15 
years. Since 2000, this model has been used extensively throughout the world in 116 different countries in lakes, reservoirs, estuaries, and river systems.

Reasons for using CE-QUAL-W2 to model Chester Morse Lake and the Cedar River include the following:

1. The model allows for modeling both lakes and rivers, hence creating a consistent modeling platform for the whole system.

2. The model can account for the complex hydrodynamic exchange between the main lake and Masonry Pool.

3. The model is able to capture longitudinal changes in temperature - critical in a system of this size and shape.

4. The model links water quality with fish habitat and bioenergetics. 


\section{Overview of Modeling Data Requirements}

In order to set up this model, specific data were required to provide the forcing

functions to the system. In addition, data were required for comparison to model

predictions. A list of these data is shown in Table 2 (Berger and Wells, 2011).

Table 1. Data needs for modeling the reservoir and river system (Berger and Wells, 2011)

\begin{tabular}{|c|l|l|}
\hline$\#$ & Data Type & Why necessary? \\
\hline $\mathbf{1}$ & $\begin{array}{l}\text { Bathymetric } x-y-z \text { data of the reservoir and } \\
\text { rivers }\end{array}$ & $\begin{array}{l}\text { Construct model segments } \\
\text { and layers }\end{array}$ \\
\hline $\mathbf{2}$ & $\begin{array}{l}\text { Flow rates (Q) and temperatures (T) for all } \\
\text { inflows }\end{array}$ & $\begin{array}{l}\text { These are the model } \\
\text { boundary conditions; } \\
\text { continuous data are } \\
\text { preferable, otherwise the } \\
\text { model can use any temporal } \\
\text { resolution available }\end{array}$ \\
\hline $\mathbf{3}$ & $\begin{array}{l}\text { Outlet structure details for the power house } \\
\text { and spillways, including rating curves for the } \\
\text { spillways }\end{array}$ & $\begin{array}{l}\text { The centerline elevation of } \\
\text { the outlets and the weir crest } \\
\text { elevations are of importance } \\
\text { in predicting the vertical } \\
\text { stratification in the reservoir } \\
\text { system and the correct } \\
\text { outflow during spill events } \\
\text { unless these are measured } \\
\text { and known) }\end{array}$ \\
\hline $\mathbf{4}$ & $\begin{array}{l}\text { Flow rates and locations of outflows from the } \\
\text { system, including the dam outlet, irrigation } \\
\text { and other water withdrawals }\end{array}$ & $\begin{array}{l}\text { These are model boundary } \\
\text { conditions. }\end{array}$ \\
\hline $\mathbf{5}$ & $\begin{array}{l}\text { Meteorological data such as air temperature, } \\
\text { dew point temperature (or relative } \\
\text { humidity), wind speed and direction, solar } \\
\text { radiation and cloud cover at an hourly } \\
\text { frequency }\end{array}$ & $\begin{array}{l}\text { These are model boundary } \\
\text { conditions. }\end{array}$ \\
\hline $\mathbf{6}$ & $\begin{array}{l}\text { Water surface elevation data } \\
\text { athe system is accurate. }\end{array}$ \\
\hline
\end{tabular}




\section{Model Bathymetry}

Chester Morse Lake

Bathymetry Development

Bathymetric data for Chester Morse Lake provided by Seattle Public Utilities (SPU)

(Paige, 2009) shown in Figure 2 and USGS DEM coverage of the surrounding area were combined to create a composite elevation map, a 3-D representation of which is shown in Figure 3.

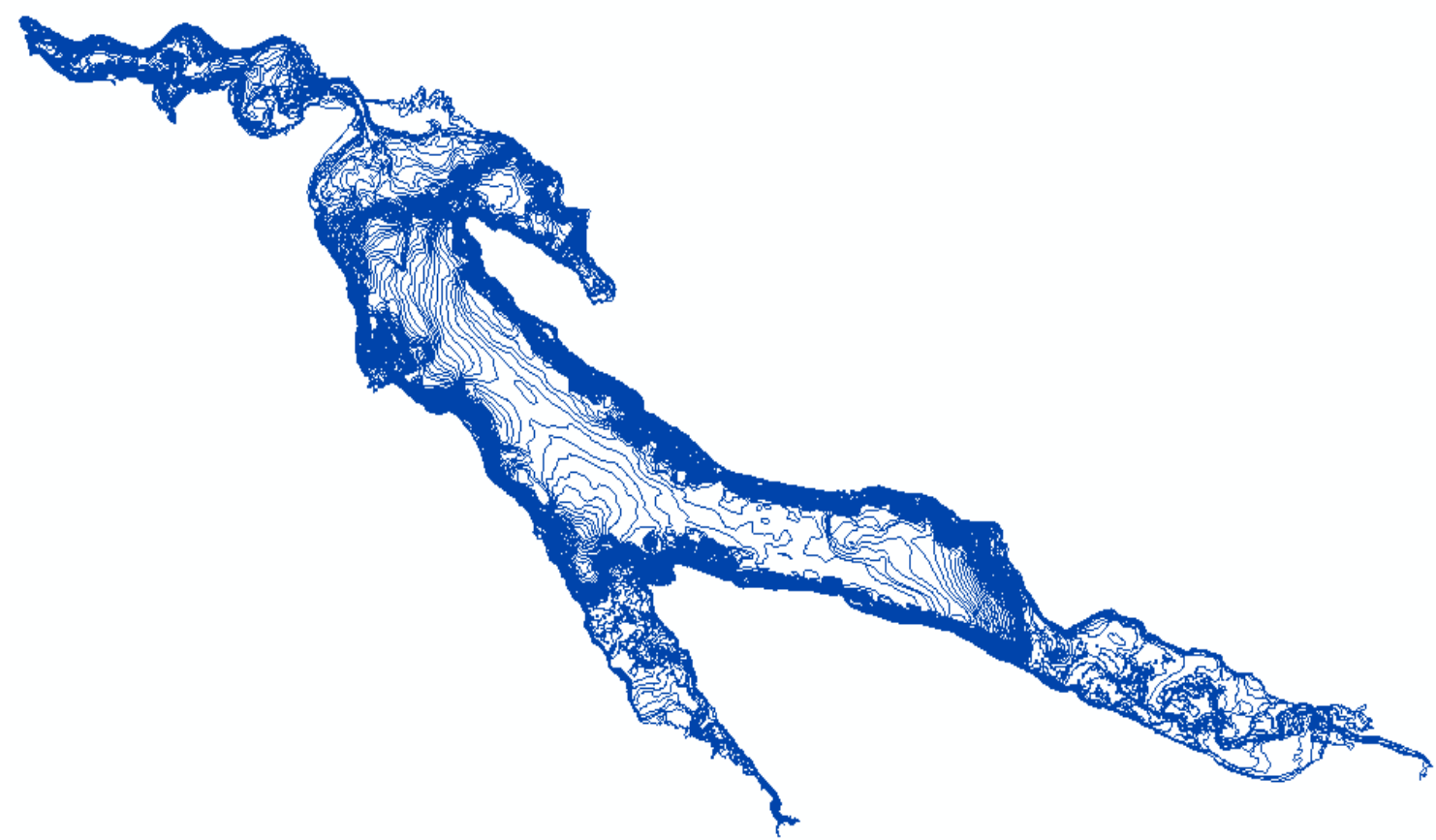

Figure 2. Original bathymetry data for Chester Morse Lake (SPU) 


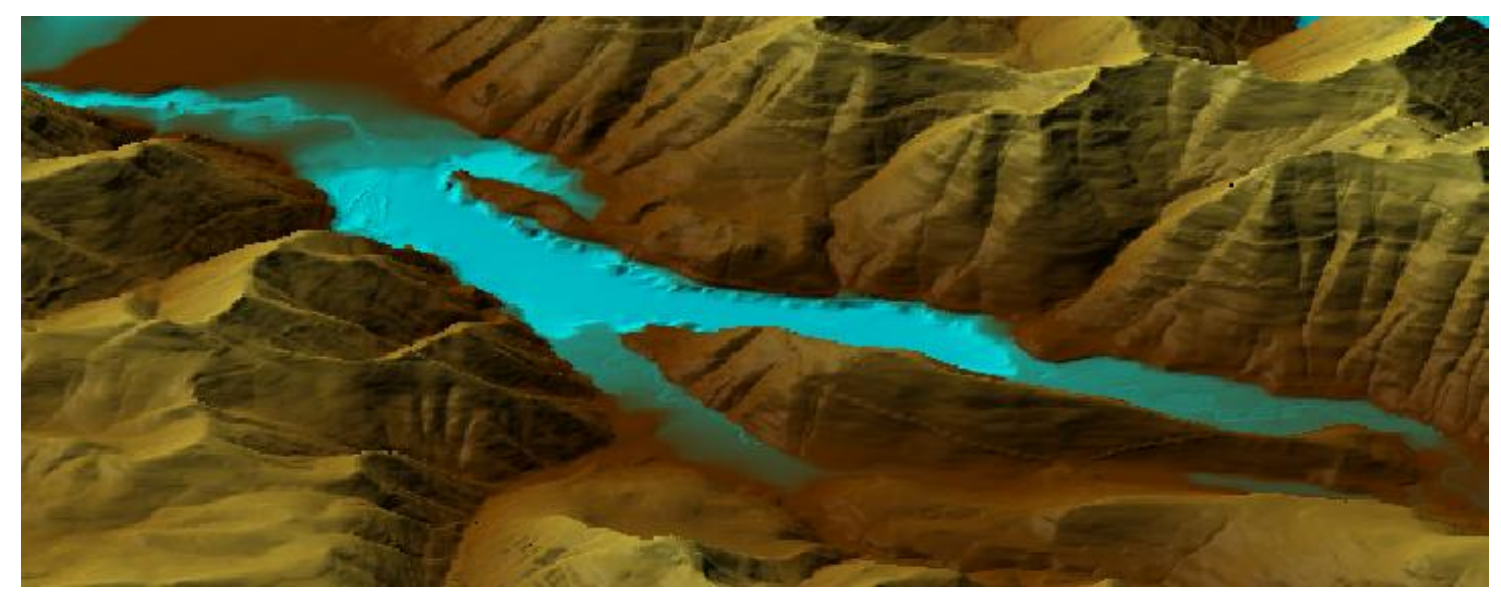

Figure 3. 3-D elevation map of Chester Morse Lake and surroundings

\section{Grid Development}

The lake was divided into multiple model segments. These were organized i Elevation, main branches as shown in Figure 4. Branches 1, 2, and 3 were designated WB 1 (water body i) and branch 4 (also called the Masonry Pool) was designated WB 2. A summary of the model grid details is shown in Table 2.

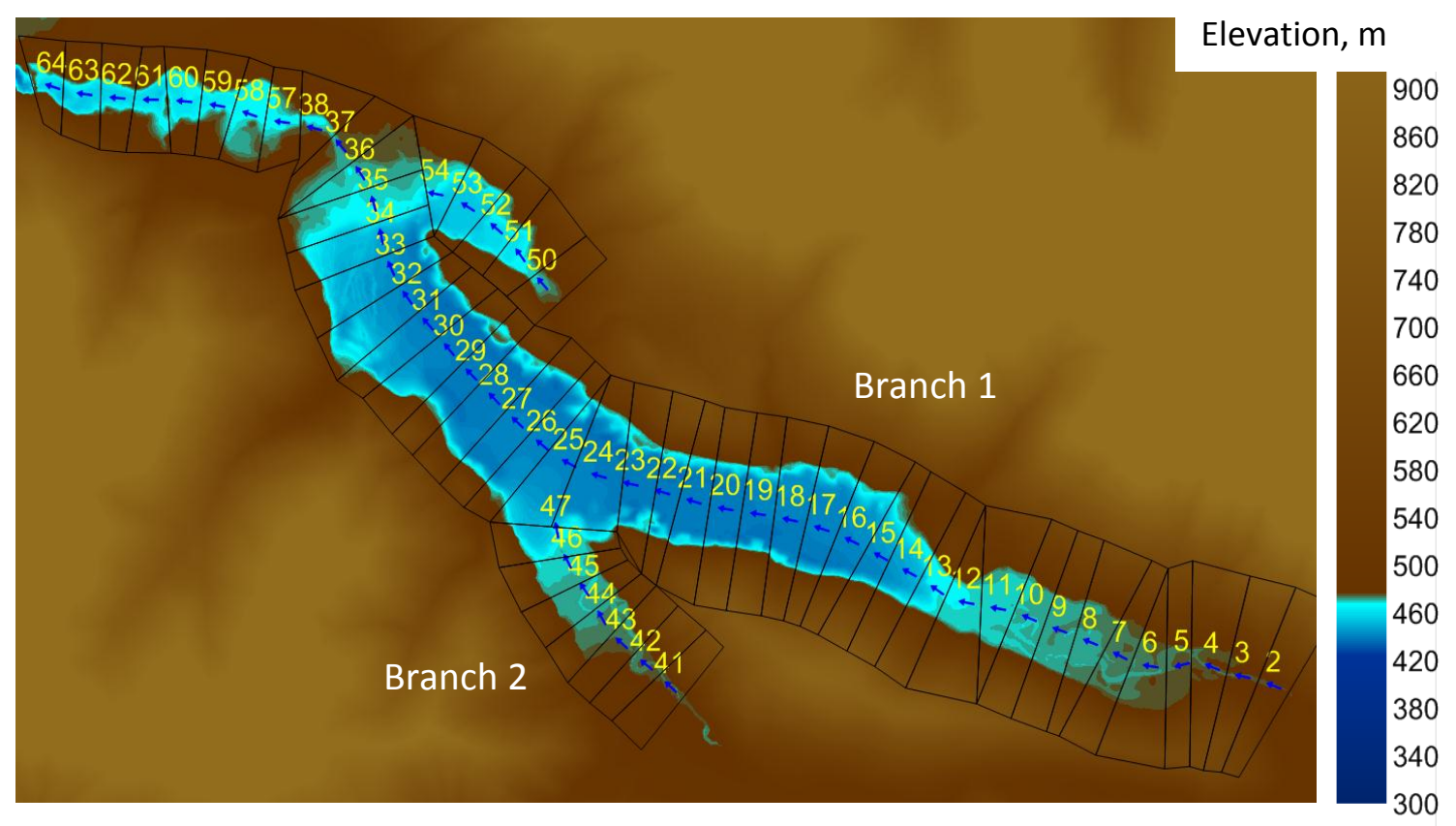

Figure 4. Chester Morse Lake Model branches, segments 
Table 2. Chester Morse Lake model grid details

\begin{tabular}{|c|c|}
\hline $\begin{array}{c}\text { Number of water } \\
\text { bodies }\end{array}$ & 2 \\
\hline Number of branches & 4 \\
\hline Number of segments & 65 \\
\hline $\begin{array}{c}\text { Minimum grid } \\
\text { elevation }\end{array}$ & $434.0 \mathrm{~m}$ \\
\hline $\begin{array}{c}\text { Maximum grid } \\
\text { elevation }\end{array}$ & $499.8 \mathrm{~m}$ \\
\hline Number of layers & 110 \\
\hline Layer thickness & $0.61 \mathrm{~m}$ \\
\hline Latitude & 47.4 \\
\hline Longitude & -120.0 \\
\hline
\end{tabular}

Table 3 summarizes the characteristics of each model branch.

Table 3. Chester Morse Lake model branch details

\begin{tabular}{cccccc}
\hline $\begin{array}{c}\text { Branch } \\
\text { Number }\end{array}$ & $\begin{array}{c}\text { Number of } \\
\text { active } \\
\text { segments }\end{array}$ & $\begin{array}{c}\text { Upstream } \\
\text { active } \\
\text { segment }\end{array}$ & $\begin{array}{c}\text { Downstream } \\
\text { active } \\
\text { segment }\end{array}$ & $\begin{array}{c}\text { Centerline } \\
\text { Length of } \\
\text { Branch, } \mathbf{~}\end{array}$ & $\begin{array}{c}\text { Average Segment } \\
\text { Length, } \mathbf{m}\end{array}$ \\
\hline $\mathbf{1}$ & 37 & 2 & 38 & 9256.3 & 250.2 \\
$\mathbf{2}$ & 7 & 41 & 47 & 1761.8 & 251.7 \\
$\mathbf{3}$ & 5 & 50 & 54 & 1381.7 & 276.3 \\
$\mathbf{4}$ & 8 & 57 & 64 & 2126.8 & 265.9 \\
\hline
\end{tabular}


A plan view of the model segments, orientation, and connectivity is shown in Figure 5.

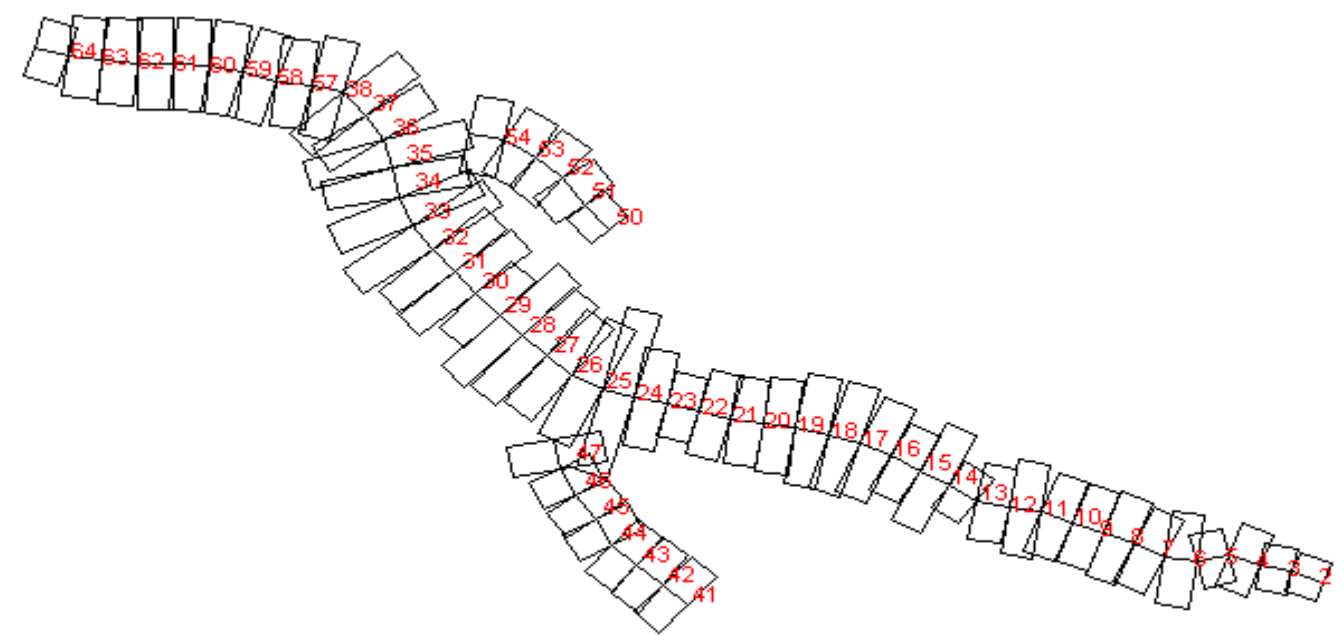

Figure 5. Model configuration plan-view

A side view of the model segments is shown in Figure 6.

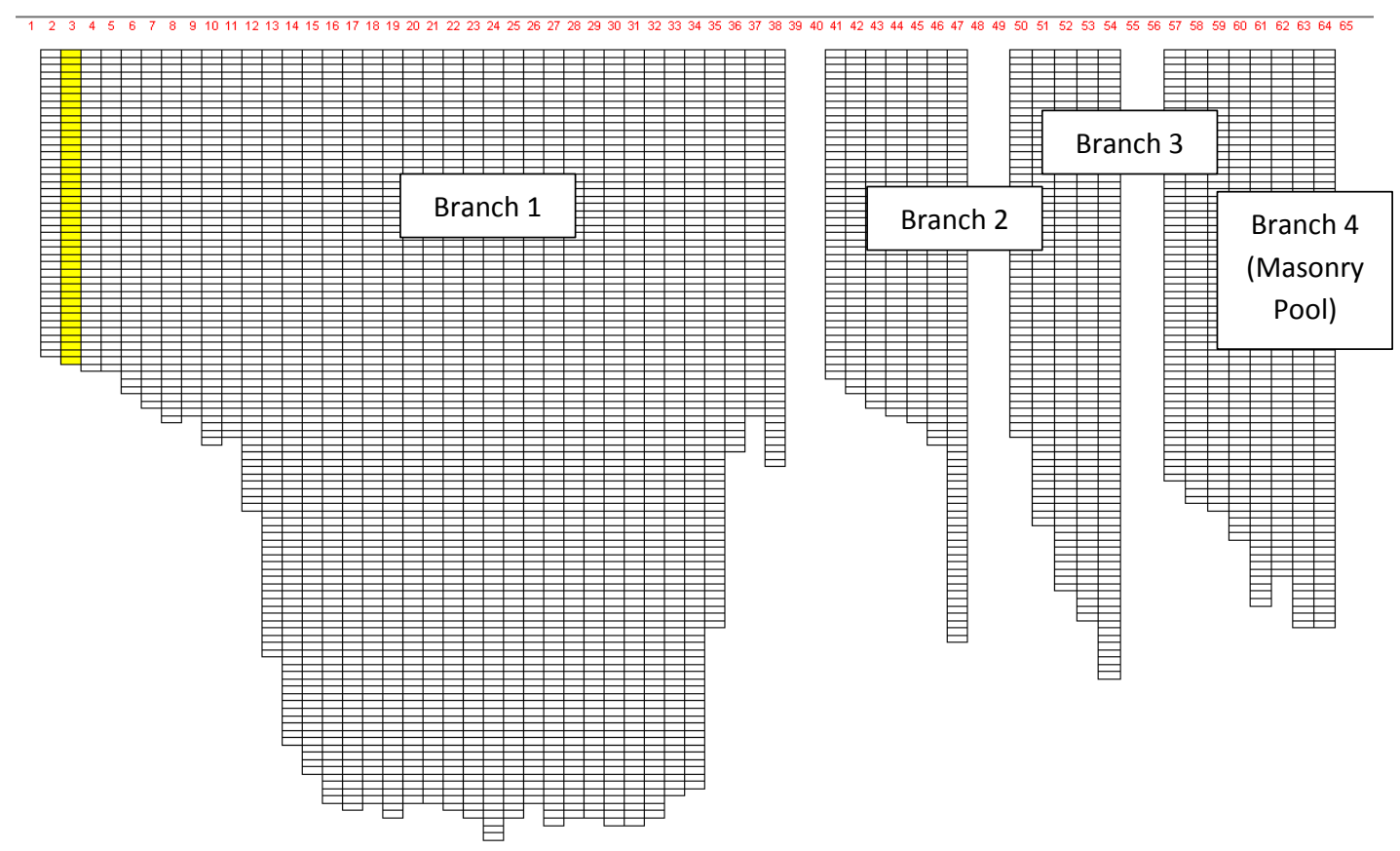

Figure 6. Model configuration side-view 
A representative vertical slice of segment 33 is shown in Figure 7.
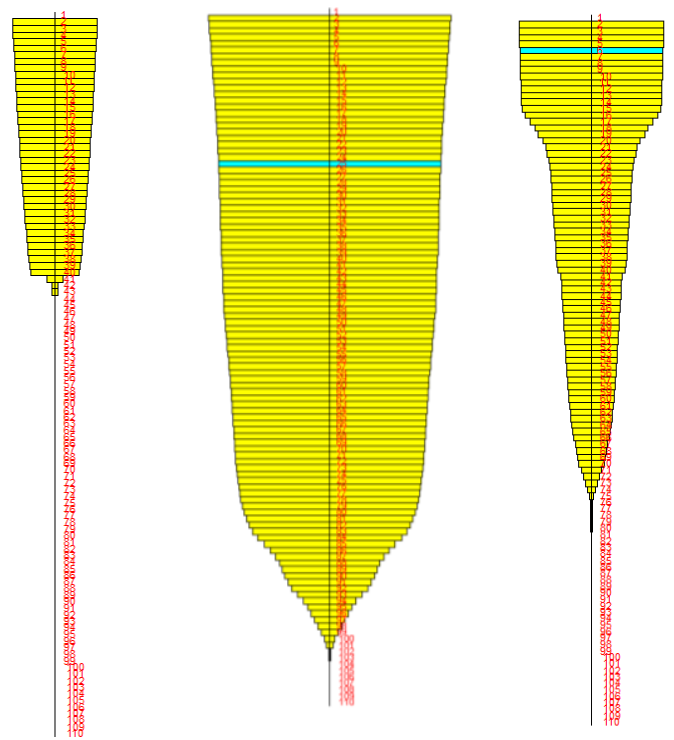

Figure 7. Vertical model segment slices: left segment 2, middle segment 33 and right model segment 63 (Masonry Pool)

\section{Verification of Model Grid}

The final model grid was verified by comparing it to volume-elevation and surface areaelevation curves of Chester Morse Lake provided by Seattle Public Utilities (SPU) (Paige, 2009). Figure 8 and Figure 9 display the model grid vs. SPU data comparison for volume and surface area, respectively. The comparison shows very close agreement between data and model grid. 


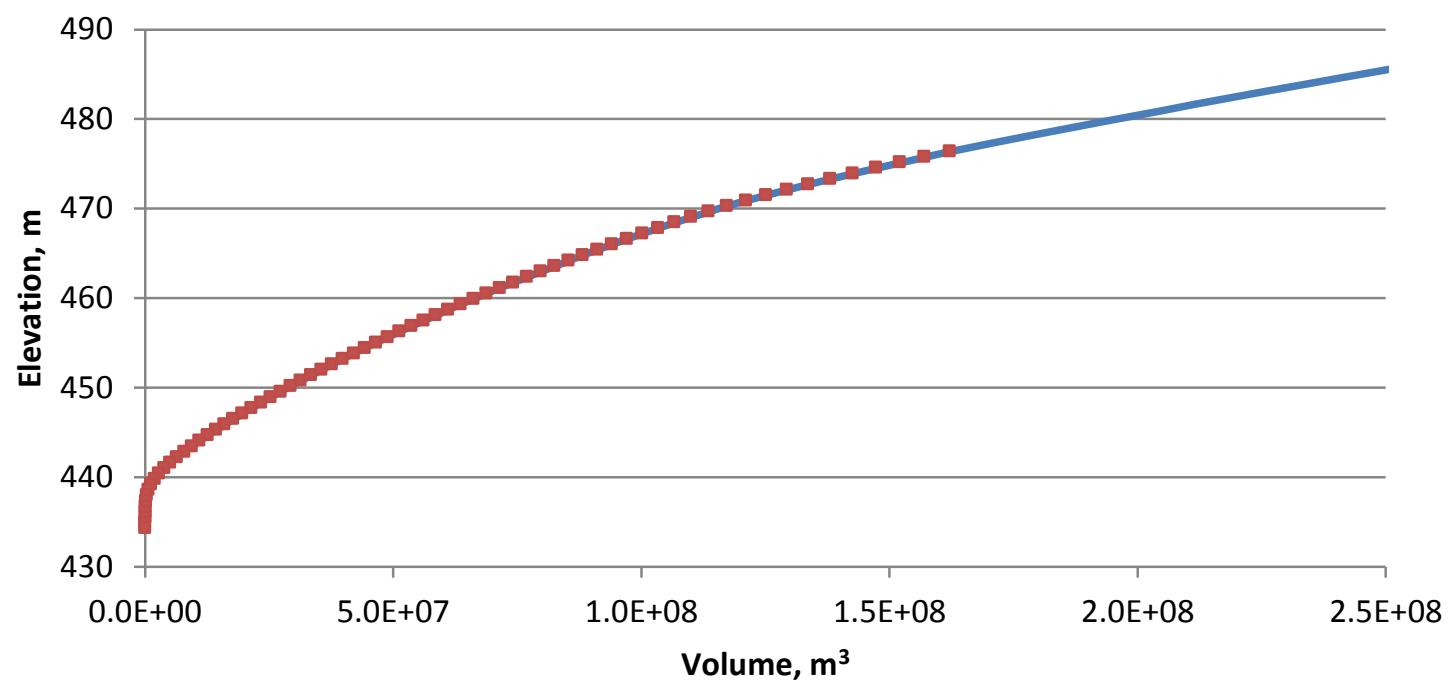

Model - SPU

Figure 8. Chester Morse Lake volume-elevation curve

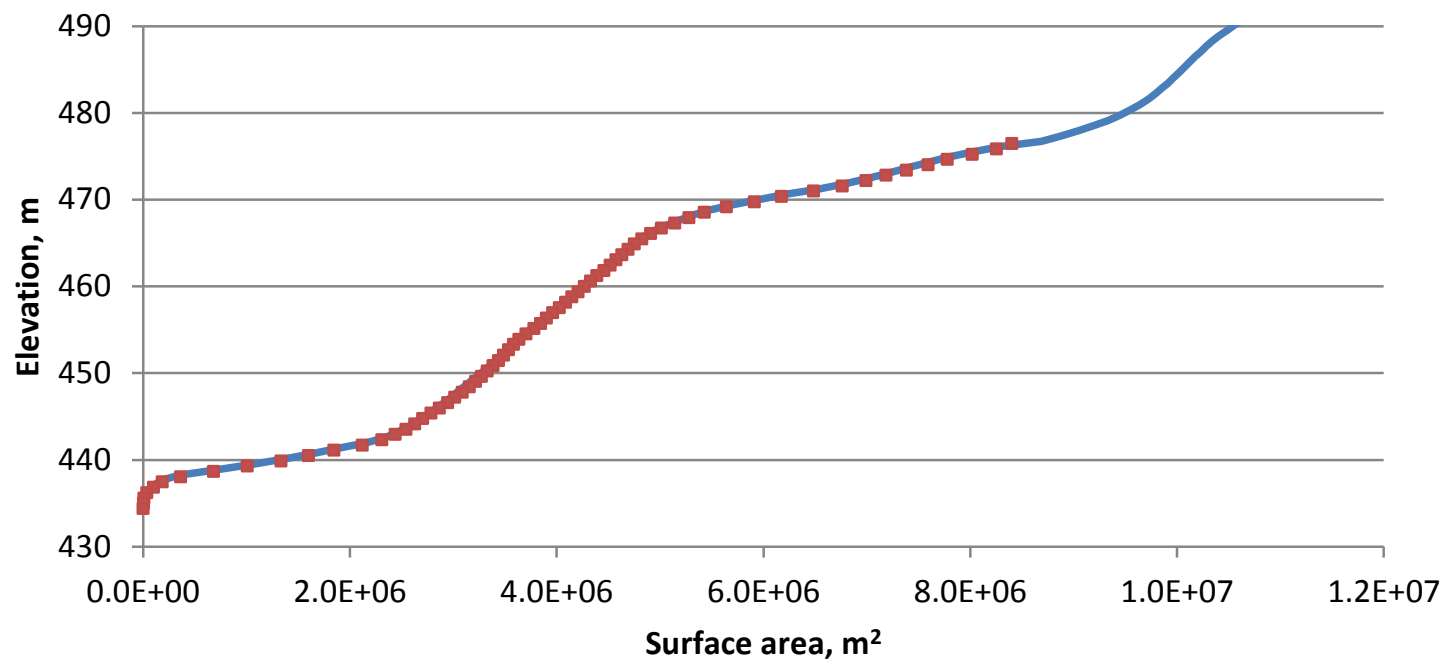

$\longrightarrow$ Model - SPU

Figure 9. Chester Morse Lake surface area-elevation curve 


\section{Cedar River below Chester Morse Lake}

\section{Bathymetry Development}

The Cedar River model bathymetry was developed using 93 cross-sections taken between Cedar Falls (just downstream of Chester Morse Lake) and Landsburg, WA (Paige, 2010). These transects were combined with a USGS DEM of the surrounding area as seen in Figure 10. The composite 3-D elevation map is shown in Figure 11. This DEM was used to estimate Cedar River bathymetry between the Masonry Dam and Cedar Falls.

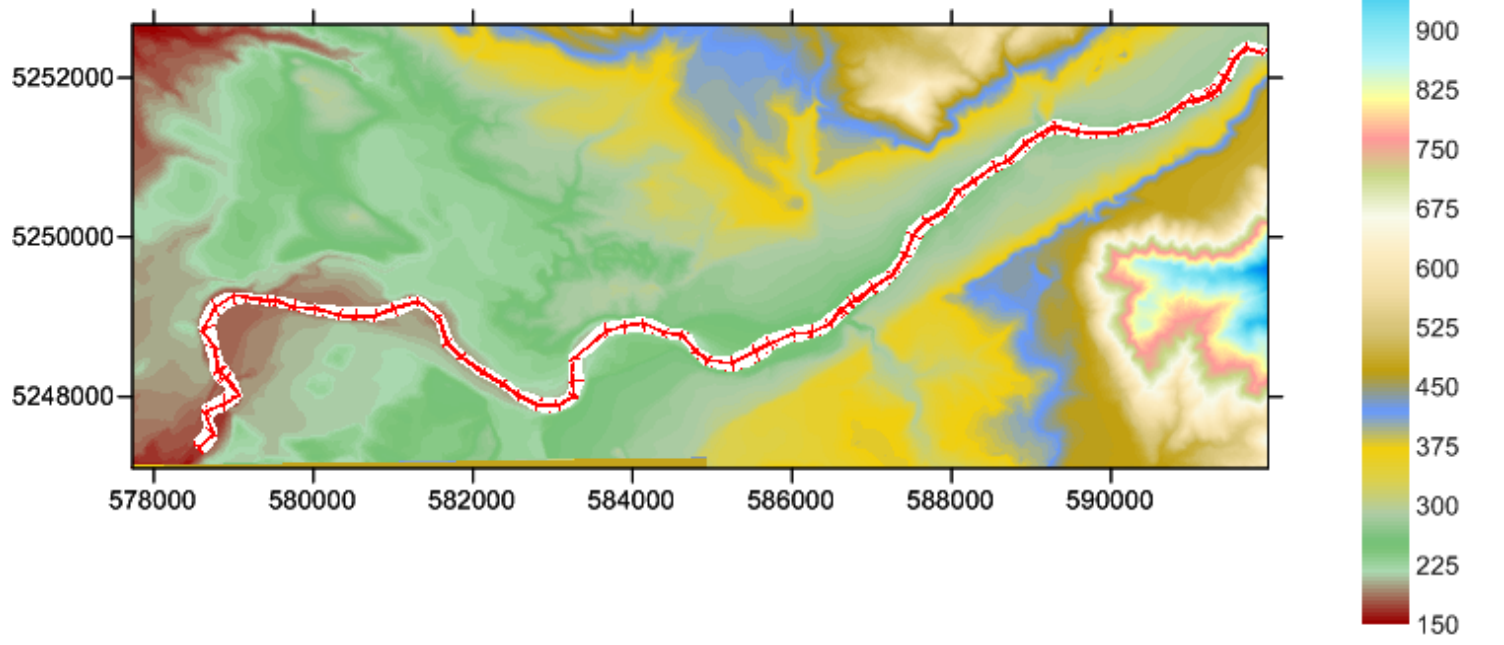

Figure 10. Cedar River transect data (in red) and USGS DEM coverage of surrounding area 


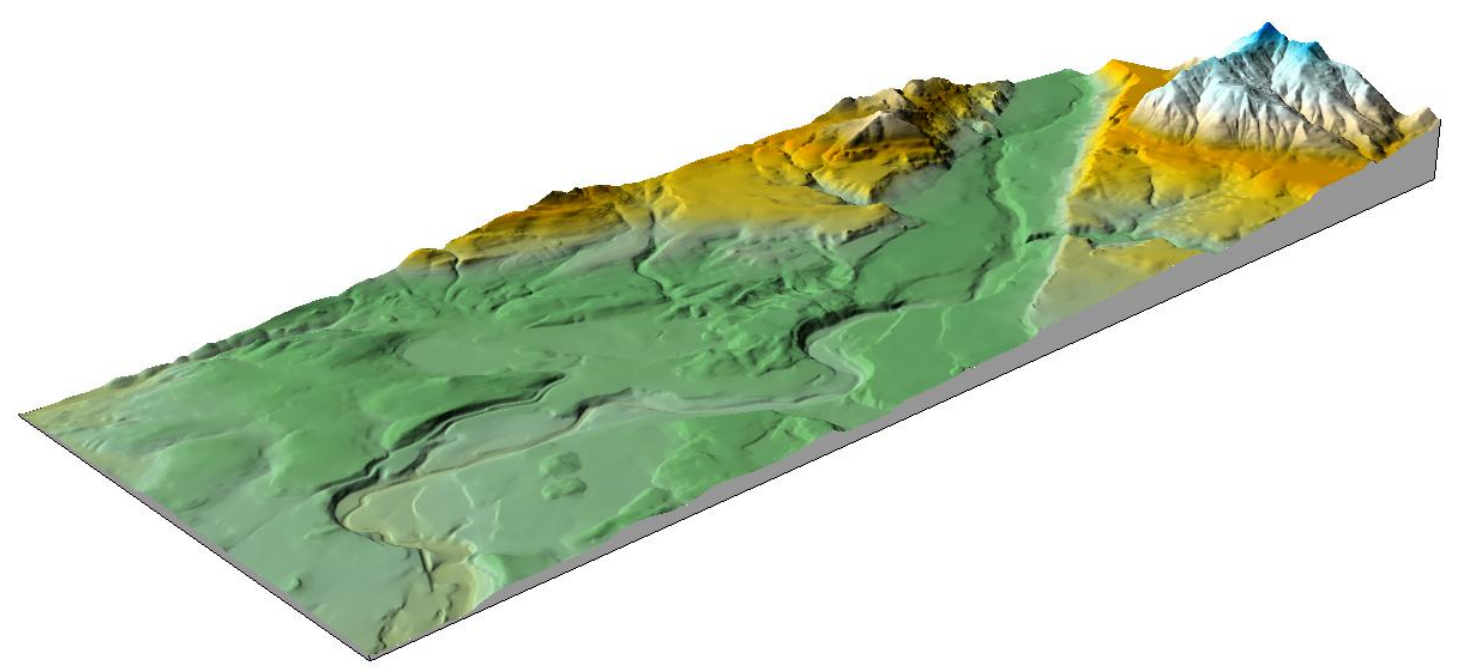

Figure 11. 3-D elevation map of Cedar River and surroundings

\section{Grid Development}

The Cedar River model was divided into a total of 5 branches, as shown in Figure 12.

Each branch was differentiated by a change in slope. Figure 13 and Figure 14 show the river centerline elevation and slope of branches 1 through 3 and 4 through 5 respectively.

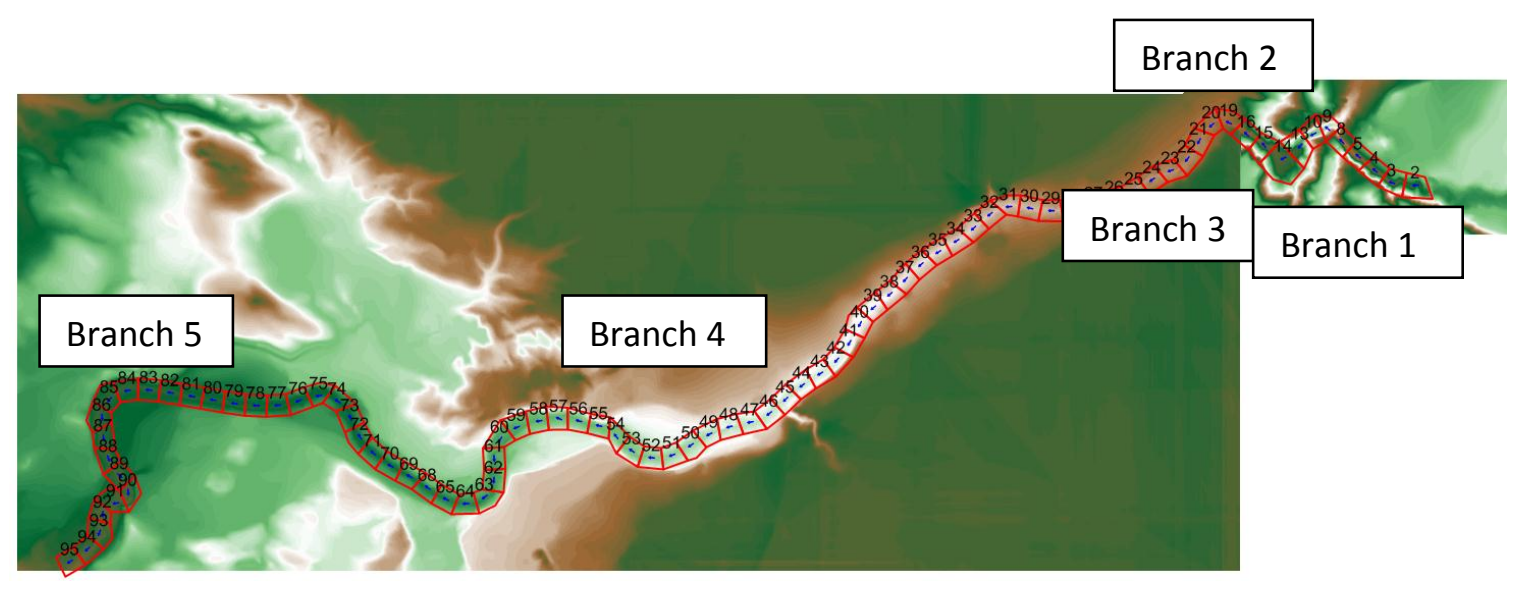

Figure 12. Cedar River Model branches, segments 


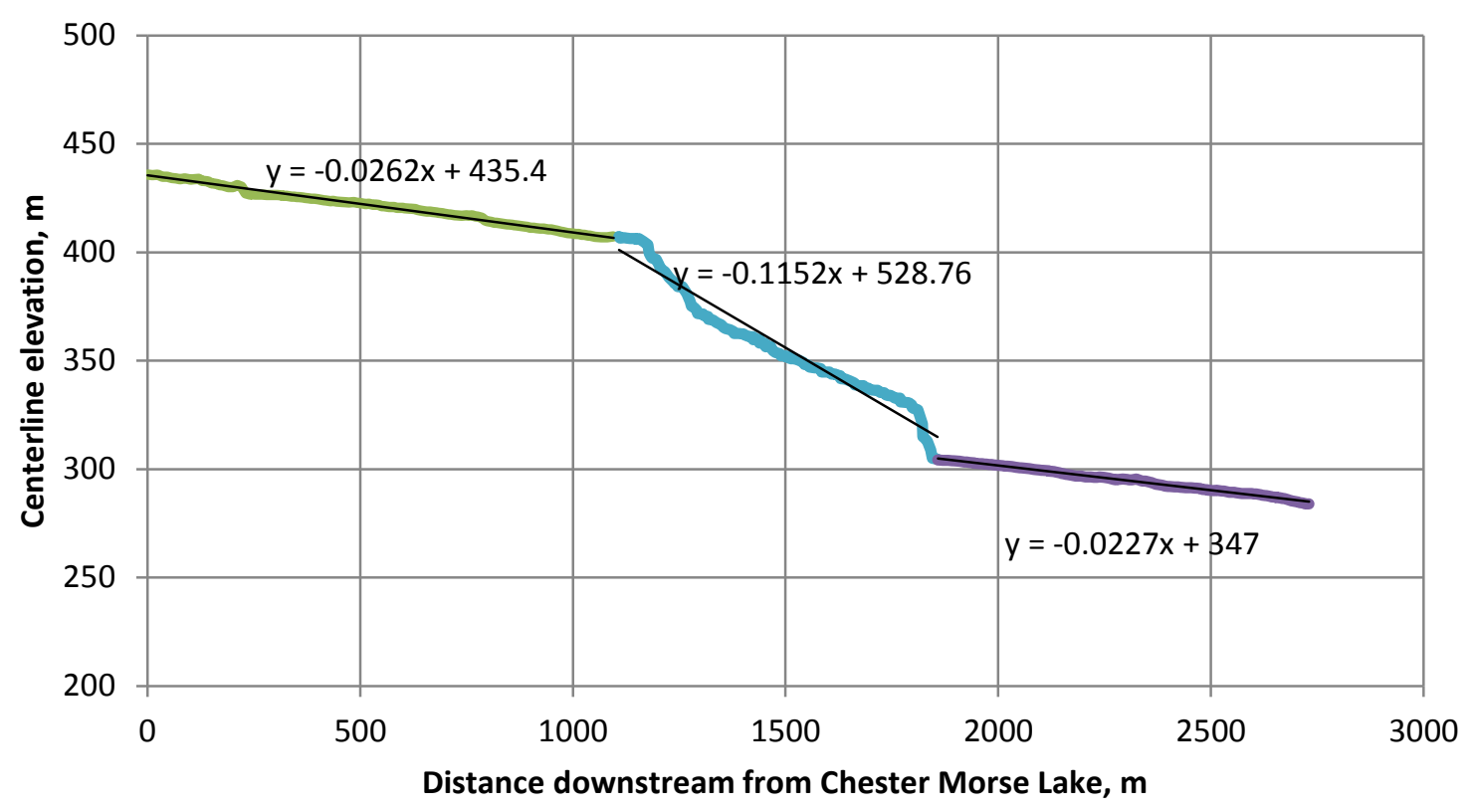

Branch $1 \oiiint$ Branch $2 \oiiint$ Branch 3

Figure 13. Centerline elevation and slope - branches 1, 2, and 3

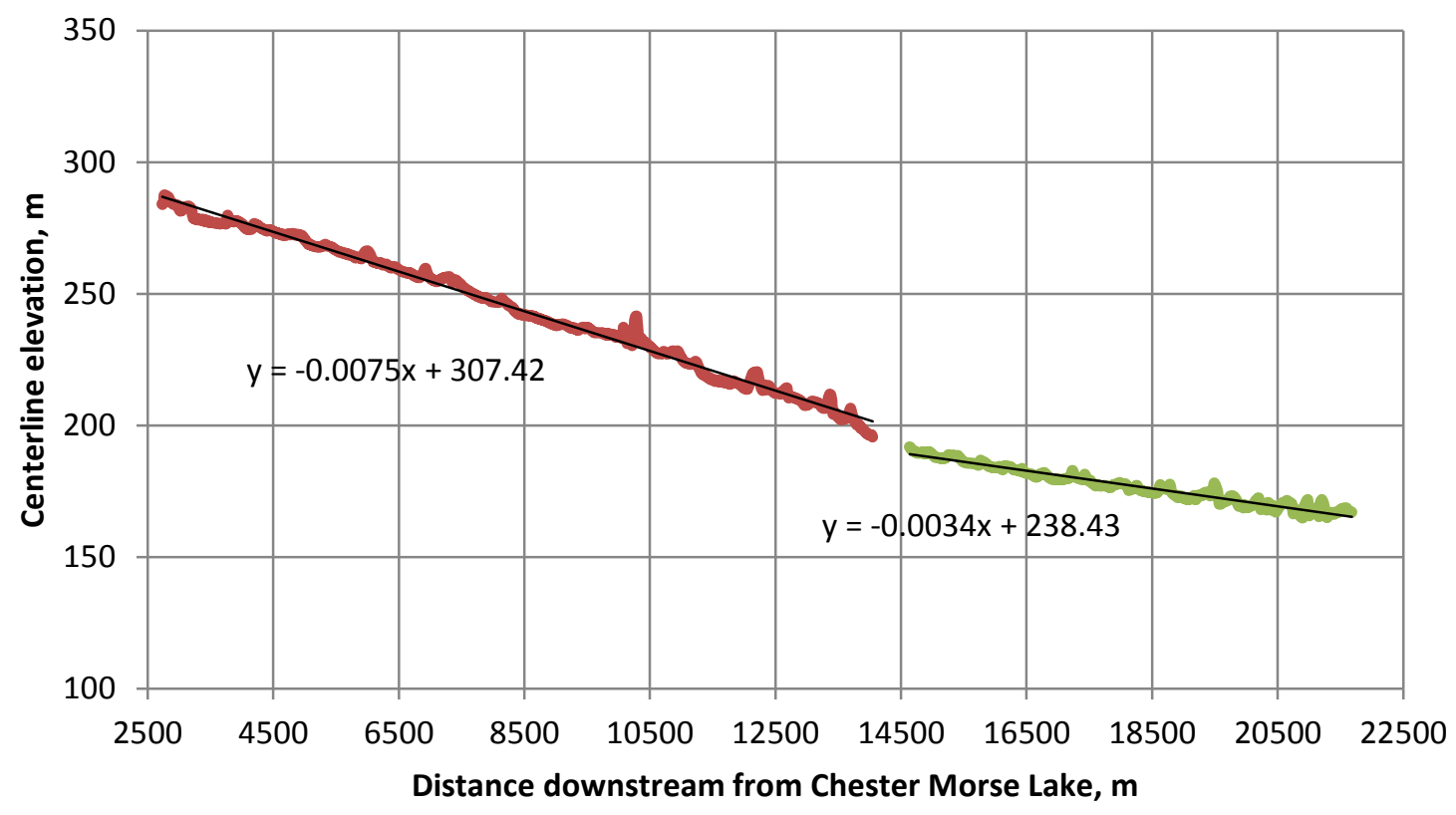

Branch $4 \longrightarrow$ Branch 5

Figure 14. Centerline elevation and slope - branches 4 and 5 
Branches 1 and 2 were designated WB 1, branches 3 and 4 were designated WB 2 and branch 5 was designated WB 3. A summary of the model grid details is shown in Table 4.

Table 4. Cedar River model grid details

\begin{tabular}{|c|c|}
\hline $\begin{array}{c}\text { Number of water } \\
\text { bodies }\end{array}$ & 3 \\
\hline Number of branches & 5 \\
\hline $\begin{array}{c}\text { Number of segments } \\
\text { Minimum grid } \\
\text { elevation }\end{array}$ & $163.0 \mathrm{~m}$ \\
\hline $\begin{array}{c}\text { Maximum grid } \\
\text { elevation }\end{array}$ & $434.45 \mathrm{~m}$ \\
\hline Number of layers & 56 \\
\hline Layer thickness & $1.0 \mathrm{~m}$ \\
\hline Latitude & 47.4 \\
\hline Longitude & -120.0 \\
\hline
\end{tabular}

Table 5 summarizes the characteristics of each model branch.

Table 5. Cedar River model branch details

\begin{tabular}{ccccccc}
\hline $\begin{array}{c}\text { Branch } \\
\text { Number }\end{array}$ & $\begin{array}{c}\text { Number of } \\
\text { active } \\
\text { segments }\end{array}$ & $\begin{array}{c}\text { Upstream } \\
\text { active } \\
\text { segment }\end{array}$ & $\begin{array}{c}\text { Downstream } \\
\text { active } \\
\text { segment }\end{array}$ & $\begin{array}{c}\text { Centerline } \\
\text { Length of } \\
\text { Branch, } \mathbf{m}\end{array}$ & $\begin{array}{c}\text { Average } \\
\text { Segment Length, } \\
\mathbf{m}\end{array}$ & $\begin{array}{c}\text { Branch } \\
\text { Slope }\end{array}$ \\
\hline $\mathbf{1}$ & 4 & 2 & 5 & 1033 & 258.27 & 0.026 \\
$\mathbf{2}$ & 3 & 8 & 10 & 775 & 258.27 & 0.115 \\
$\mathbf{3}$ & 4 & 13 & 16 & 1033 & 258.27 & 0.023 \\
$\mathbf{4}$ & 47 & 19 & 65 & 11876 & 252.69 & 0.007 \\
$\mathbf{5}$ & 28 & 68 & 95 & 7075 & 252.69 & 0.003 \\
\hline
\end{tabular}


A plan view of the model segments, orientation, and connectivity is shown in Figure 15.

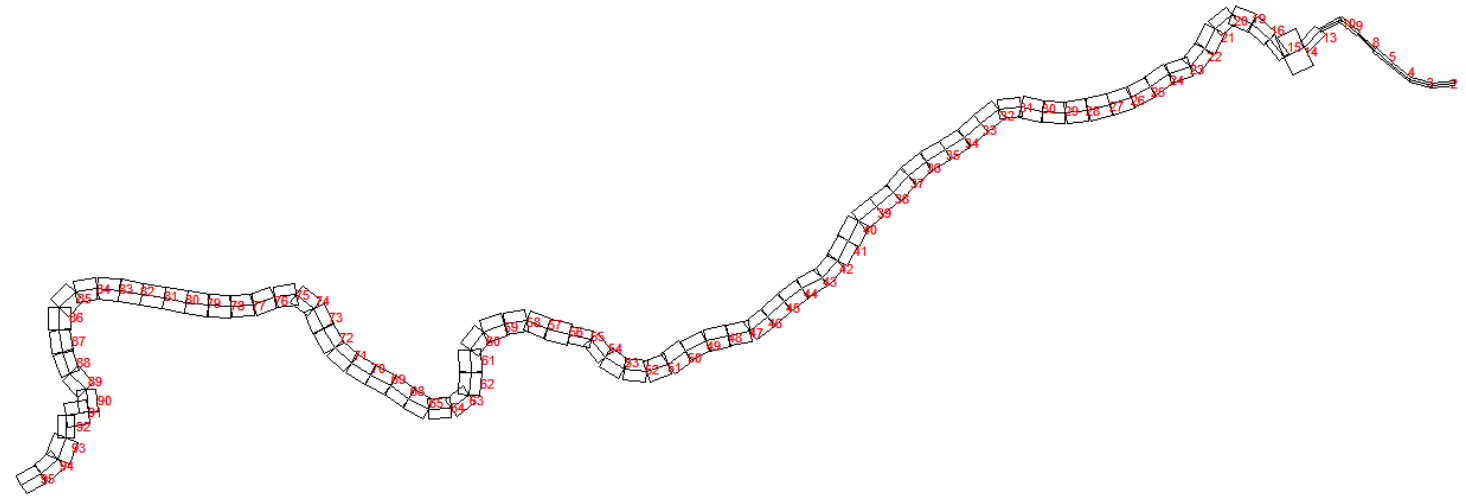

Figure 15. Plan view of Cedar River model segments

A side view of the model segments is shown in Figure 16.

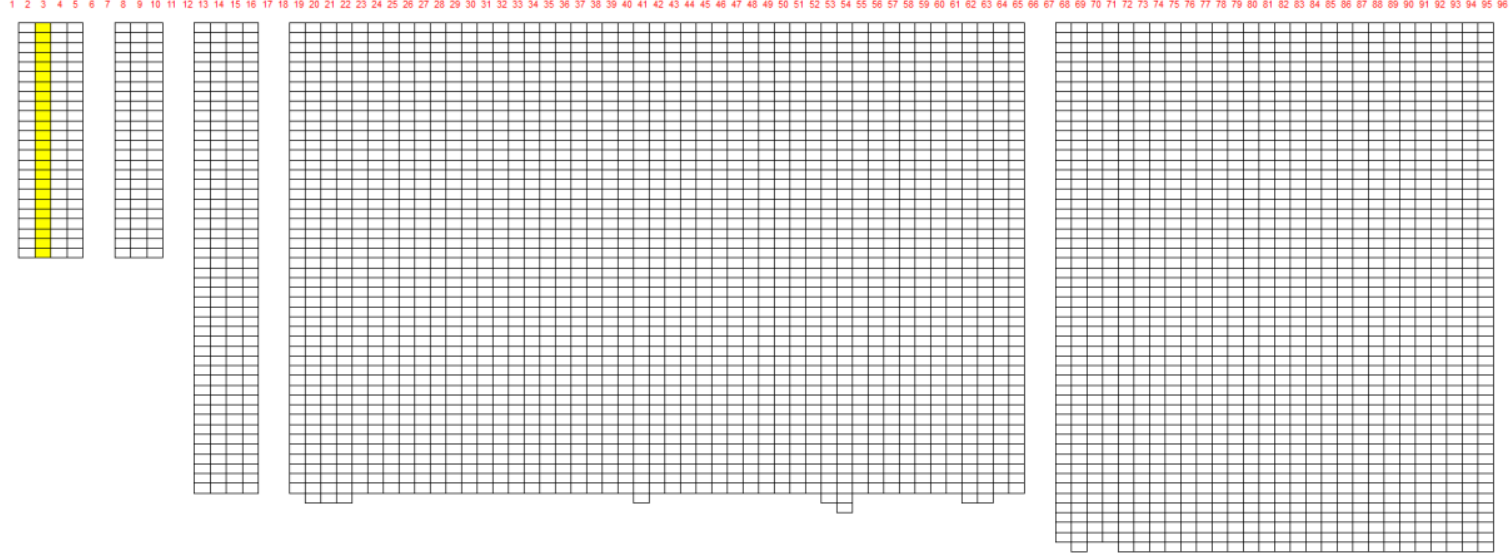

Figure 16. Side view of Cedar River model segments 
A representative vertical slice of segment 9 is shown in Figure 17.

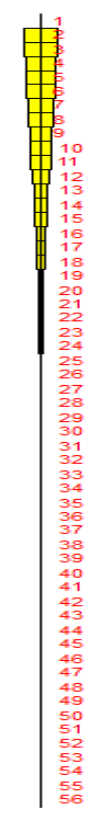

Figure 17. Cross-sectional view of Cedar River model segment 9 


\section{Connecting Chester Morse Lake and the Cedar River Models}

Chester Morse Lake provides the main inflow to the Cedar River model. The outflows

from the final segment of the lake (segment 64) flow into segment 2 , the first active segment of the Cedar River model. Some outflows from the lake, such as those that are directed through the power house, are reintroduced into the Cedar River farther downstream, at segments that correspond to the physical location of the inflow. These two models are run consecutively, rather than concurrently.

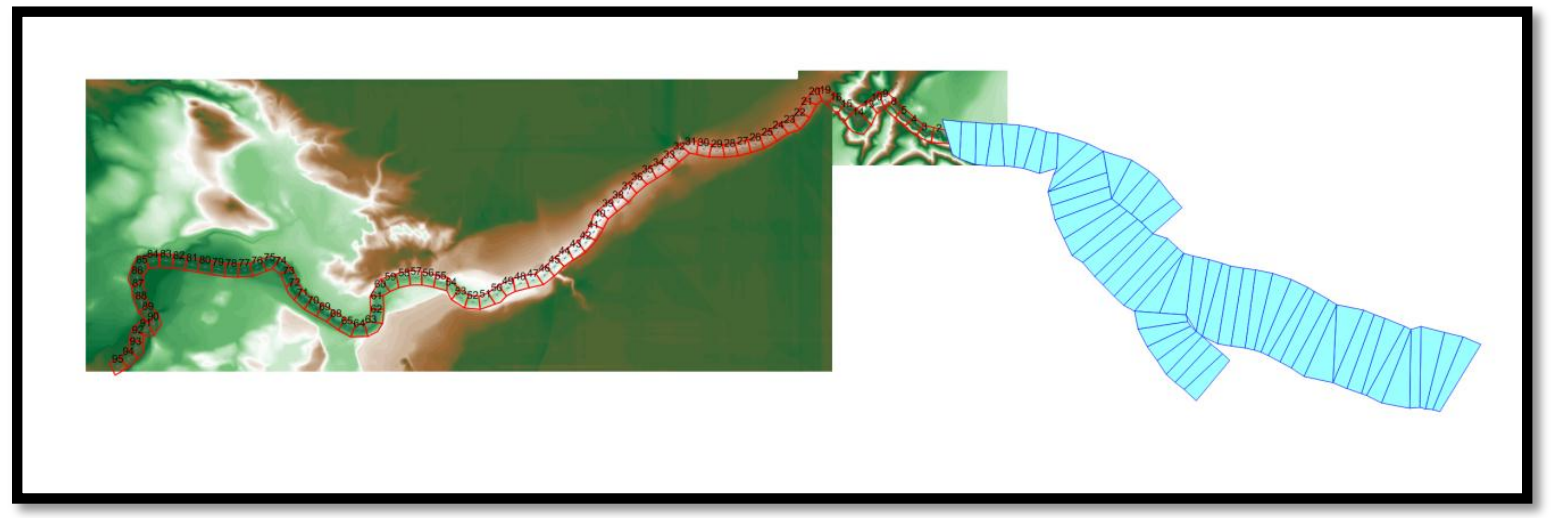

Figure 18. Full system map - Chester Morse Lake and Cedar River model connectivity 


\section{Topographic Shading}

Topographic shading was calculated for both Chester Morse Lake and the Cedar River using DEMs of the surrounding topography. The algorithm used in the model uses the position of the sun (calculated internally in the model for each day) in comparison to the angles of the surrounding topography and determines which is smaller. If the angle of the sun is less than that of the surrounding topography, then the short wave solar radiation is reduced by $90 \%$ for complete shade.

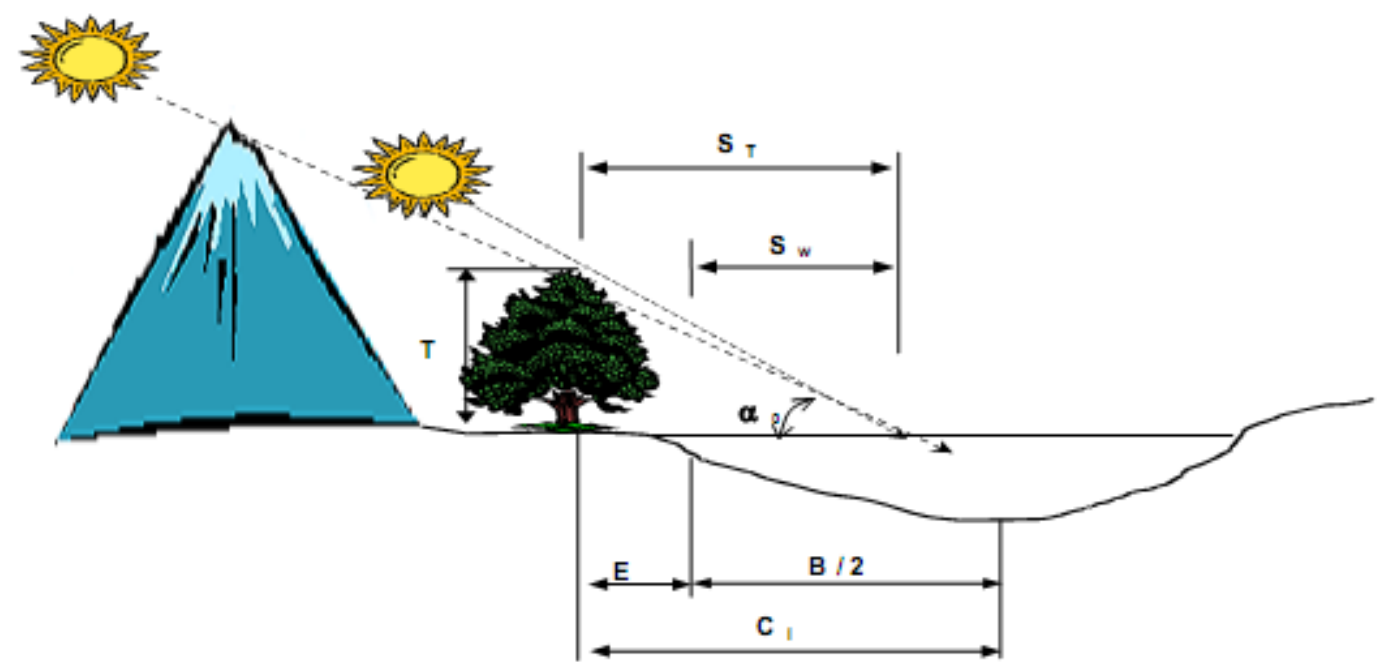

Figure 19. Topographic shading diagram (CE-QUAL-W2 User Manual) 


\section{Outlet Structures}

\section{Flashboard Dam}

A flow control structure comprised of an overflow dike with notch and two underflow gates (or "pipes") connect the main portion of Chester Morse Lake with the Masonry Pool. A side view schematic of the dam is shown in Figure 20.

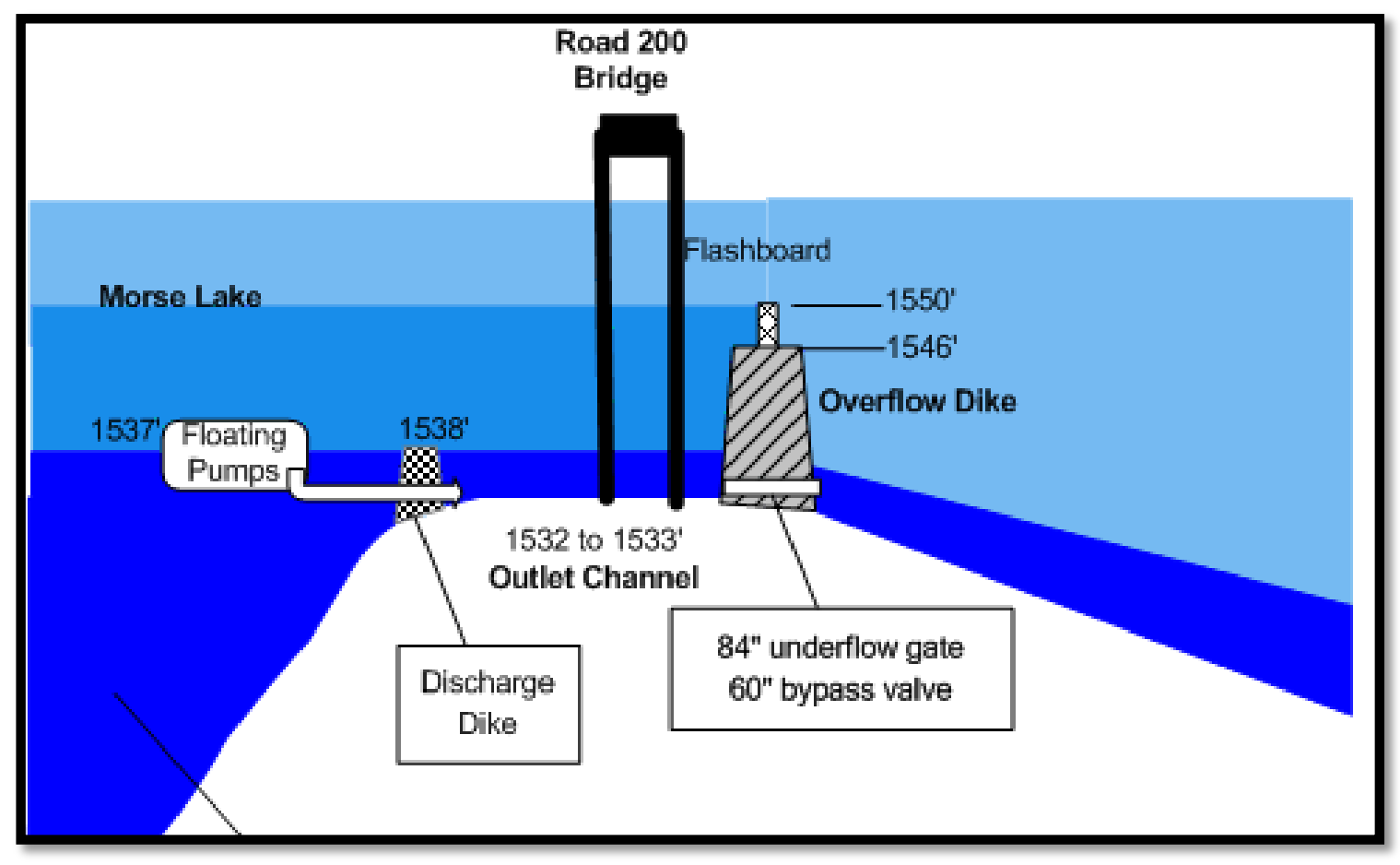

Figure 20. Schematic of flashboard dam (Paige, 2009)

Accurately estimating flow between these the main lake and Masonry pool is essential for matching water levels on both sides of the flashboard dam. These structures were modeled by creating four separate flow structures separating segments 38 and 57 . A visual model of the various flow structures is shown in Figure 21. Two weirs, A and B, are specified with widths and elevations corresponding to those of the overflow dam (A) 
and notch with flashboards up (B). The underflow gates were modeled using a pipe algorithm that allowed them to be opened and closed dynamically during the model run. The pipes could be completely closed, completely open, or any percent of open inbetween.

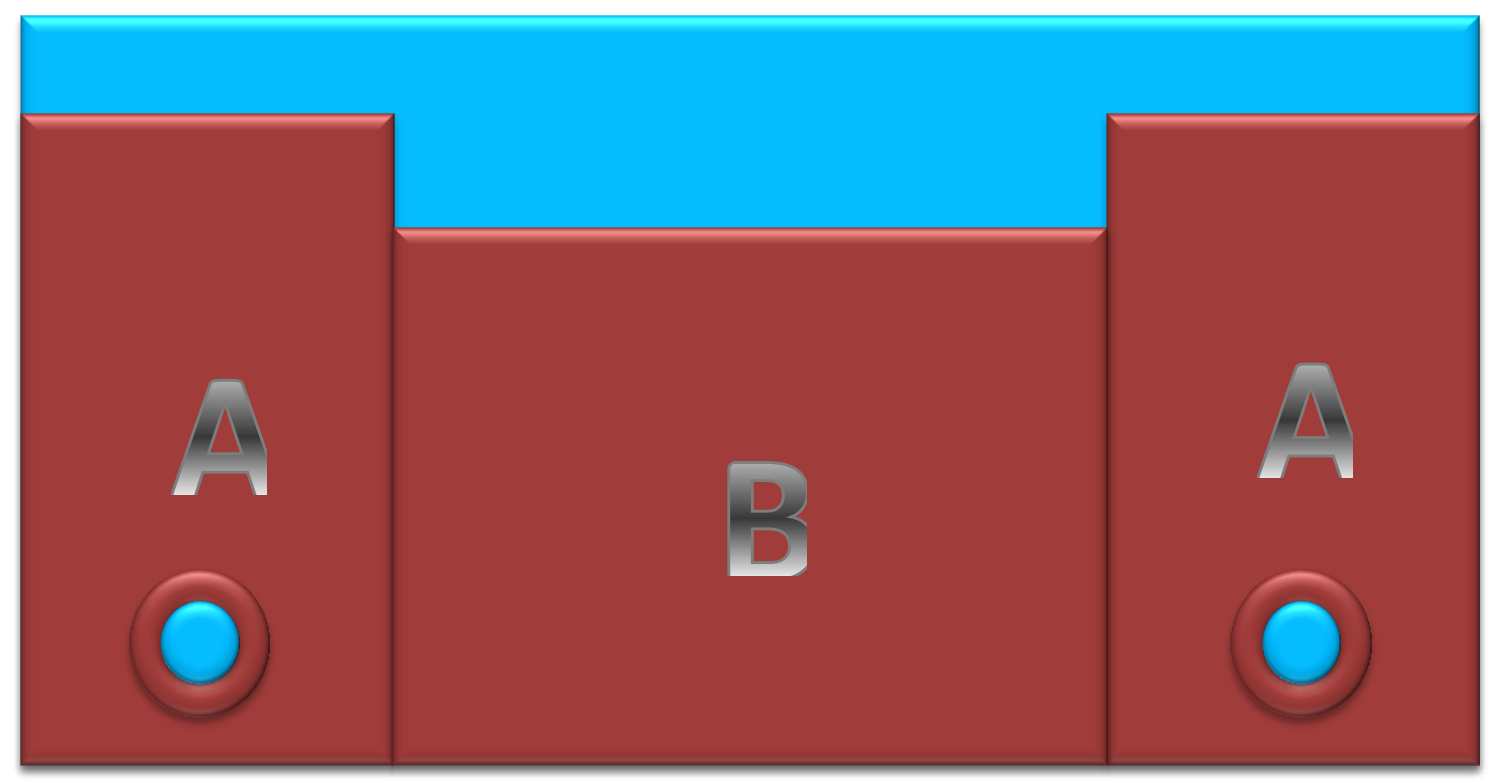

Figure 21. Flashboard dam flow structures - front view

The general equation for calculating flow over a weir takes the following form:

$$
Q=\propto \Delta h^{\beta}
$$

where:

$\alpha=$ empirical parameter

$\beta=$ empirical parameter

$\Delta \mathrm{h}=$ head difference [upstream head - spillway crest elevation (or downstream head, if submerged)] 
Flow over the overflow dike was estimated using the following equation from Clay (1995):

$$
Q=3.33 B H^{3 / 2}
$$

where:

$\alpha=3.33 * B$ (weir width)

$\beta=3 / 2$

The above approximation was used to calculate $\alpha$ and $\beta$ parameters for both weirs. A summary of the overflow dike characteristics is shown in Table 6.

Table 6. Summary of overflow dam details

\begin{tabular}{|c|c|c|}
\hline & A1 + A2 (listed as total lengths) & B (Notch) \\
\hline Elevation & $473.65 \mathrm{~m}$ & $472.58 \mathrm{~m}$ \\
\hline Length (weir width) & $90 \mathrm{~m}$ & $30 \mathrm{~m}$ \\
\hline $\boldsymbol{\alpha}$ & 300 & 100 \\
\hline $\boldsymbol{\beta}$ & $3 / 2$ & $3 / 2$ \\
\hline
\end{tabular}

The underflow structures pictured in Figure 7 were modeled using the CE-QUAL-W2 pipe algorithm. This allows for the specification of the upstream and downstream segments connected by the pipe, as well as the invert elevations, diameter, length, and roughness value (Manning's friction factor) for each pipe. The details for each of the two underflow structures are summarized in Table 7. 
Table 7. Summary details for underflow gates

\begin{tabular}{|c|c|c|}
\hline & Low Level Outlet & Bypass Valve \\
\hline Pipe diameter & 78 inch $(1.98 \mathrm{~m})$ & 69 inch $(1.75 \mathrm{~m})$ \\
\hline Pipe length & $16.5 \mathrm{ft} .(5 \mathrm{~m})$ & $210 \mathrm{ft} .(64 \mathrm{~m})$ \\
\hline $\begin{array}{c}\text { Invert elevation (outlet pipe } \\
\text { intake) }\end{array}$ & $1526 \mathrm{ft} .(465.12 \mathrm{~m})$ & $1526 \mathrm{ft} .(465.12 \mathrm{~m})$ \\
\hline Outlet elevation & $1525 \mathrm{ft} .(464.82 \mathrm{~m})$ & $1525 \mathrm{ft} .(464.82 \mathrm{~m})$ \\
\hline Material & $\begin{array}{c}\text { Concrete encased, } \\
\text { steel outlet pipe } \\
\text { (Manning's: 0.015) }\end{array}$ & $\begin{array}{c}\text { Wood stave and concrete } \\
\text { encased steel pipe } \\
\text { (through overflow dike) } \\
\text { (Manning's: 0.015) }\end{array}$ \\
\hline
\end{tabular}




\section{Masonry Dam}

The Masonry Dam is the main outflow from Chester Morse Lake and is the primary source of water for the lower Cedar River. The dam is situated at the end of segment 64. A side view schematic of the Masonry Dam and Pool is shown in Figure 22.

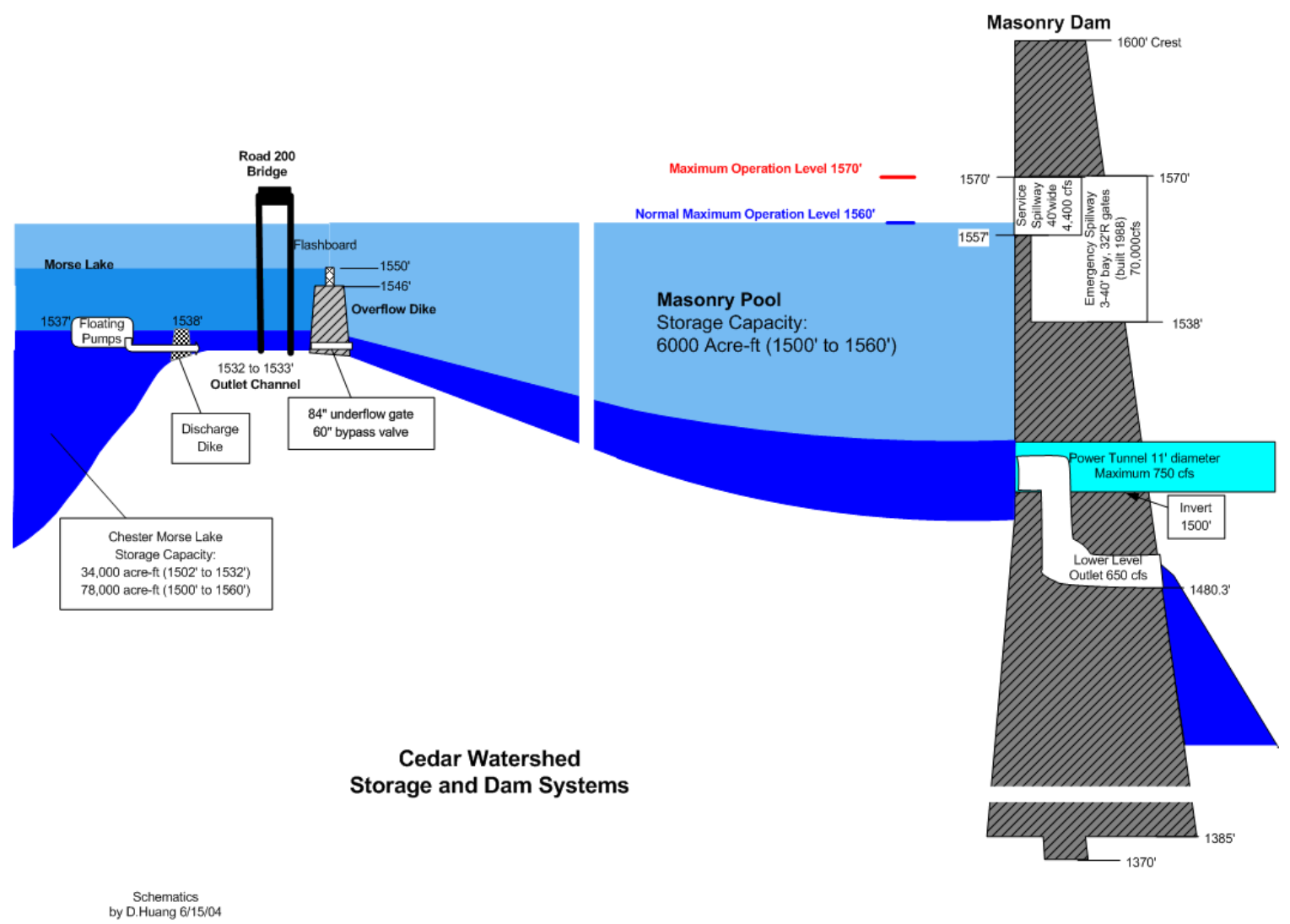

Figure 22. Schematic of Masonry Dam, Masonry Pool, and Overflow Dike (Paige, 2009)

The Masonry Dam has three flow structures by which water can leave the Masonry

Pool: the lower level outlet, the power tunnel, and the spillways. Flow for each of these structures is pulled from various elevations corresponding to their physical locations, as shown in the above diagram. 


\section{Meteorological Data}

CE-QUAL W2 requires five basic meteorological inputs to allow for accurate calculation of surface heat transfer and penetration of short wave solar radiation: air temperature, dew-point temperature, wind speed and direction, and cloud cover. Solar radiation is also a critical component, but can be calculated internally by the model.

\section{Wind Speed and Direction}

USGS station 12115900 located on-site at Chester Morse Lake was used to provide air temperature and wind speed and direction for model inputs. The composite wind-rose for this site over the four year model period from January $1^{\text {st }} 2005$ to December $31^{\text {st }}$

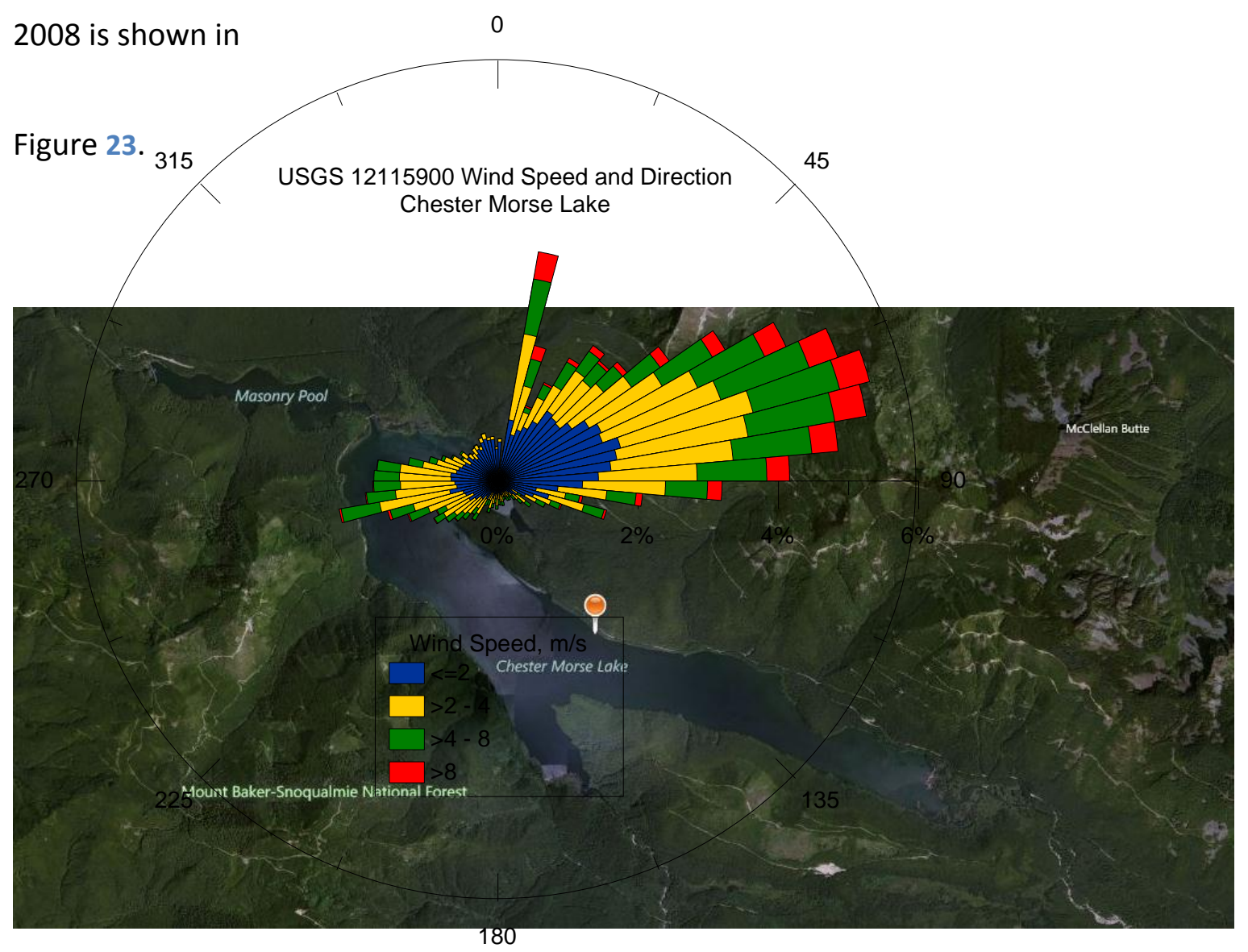

Figure 23. Chester Morse Lake wind rose (USGS 122115900) (Bing, Inc. 2009) 


\section{Air Temperature}

Air temperature data collected at Chester Morse Lake over the full model period is shown in Figure 24.
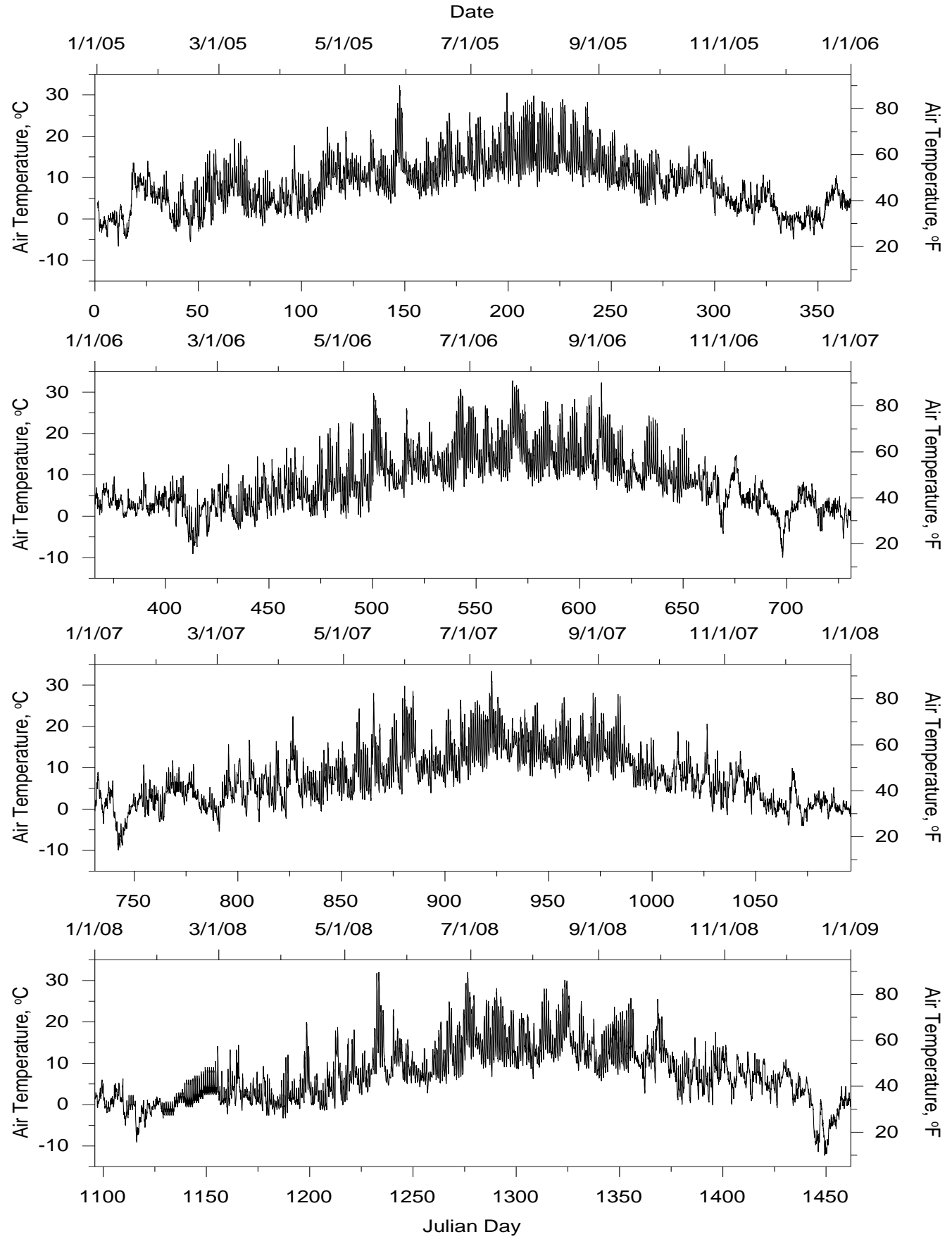

Figure 24. Chester Morse Lake air temperature (USGS 122115900) 


\section{Dew Point Temperature and Relative Humidity}

In order to calculate dew-point temperature, it was necessary to use relative humidity

data from neighboring weather stations. The stations with the closest proximity to Chester Morse Lake and with a complete data record for the model period were located in Renton, WA and Stampede Pass, WA. The locations of these sites in relation to Chester Morse Lake are shown in Figure 25.

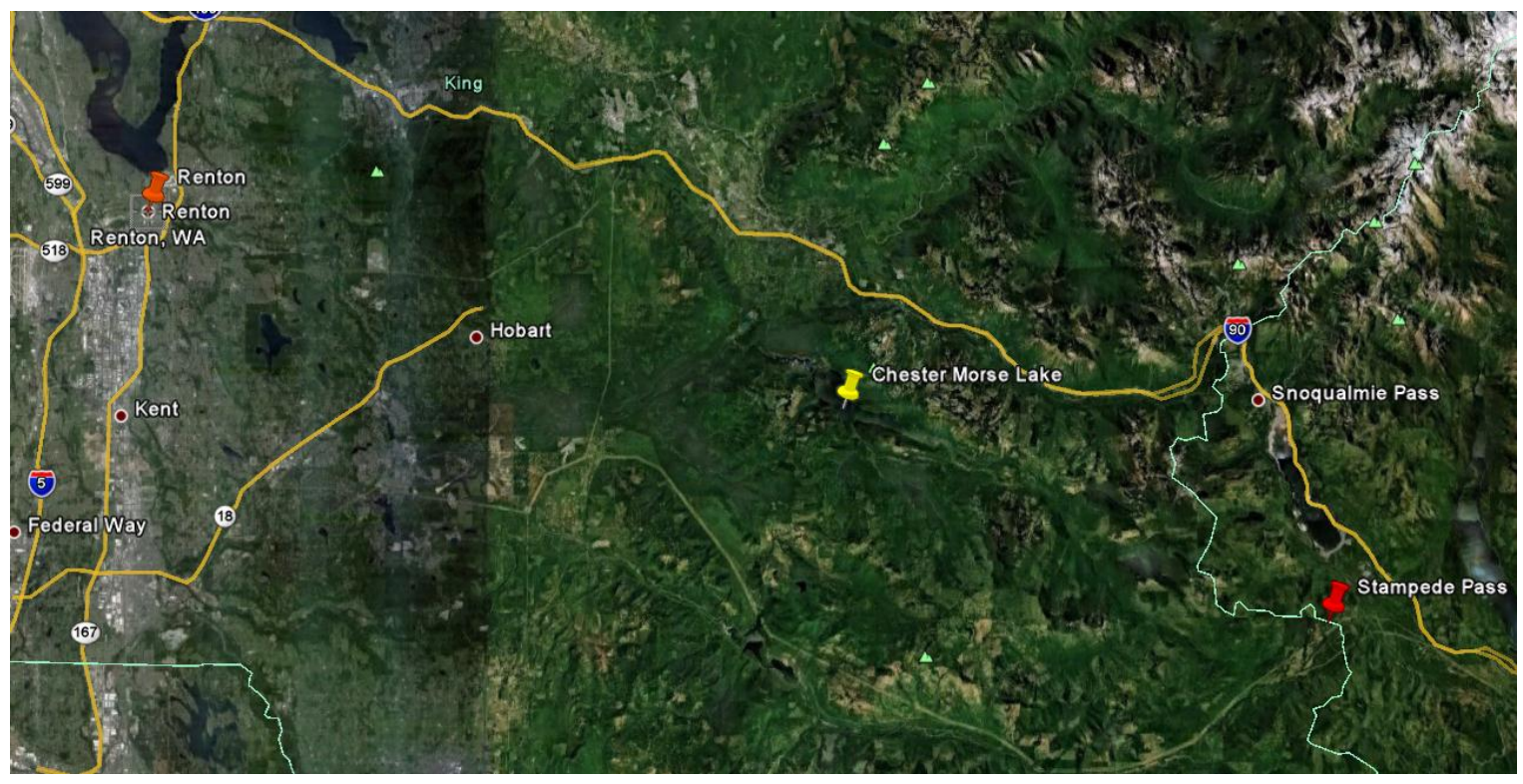

Figure 25. Map of met station locations (Google Inc., 2009)

Figure 26 shows the dew-point temperature at Chester Morse Lake calculated using relative humidity data from these two sites. Dew-point temperature is calculated using the relationship between temperature and $\mathrm{RH}$ as shown in Equation 1

Equation 1. Singh (1992) Elementary Hydrology

$$
R H=\left[\frac{112-0.1 T+T_{d}}{112+0.9 T}\right]^{8}
$$



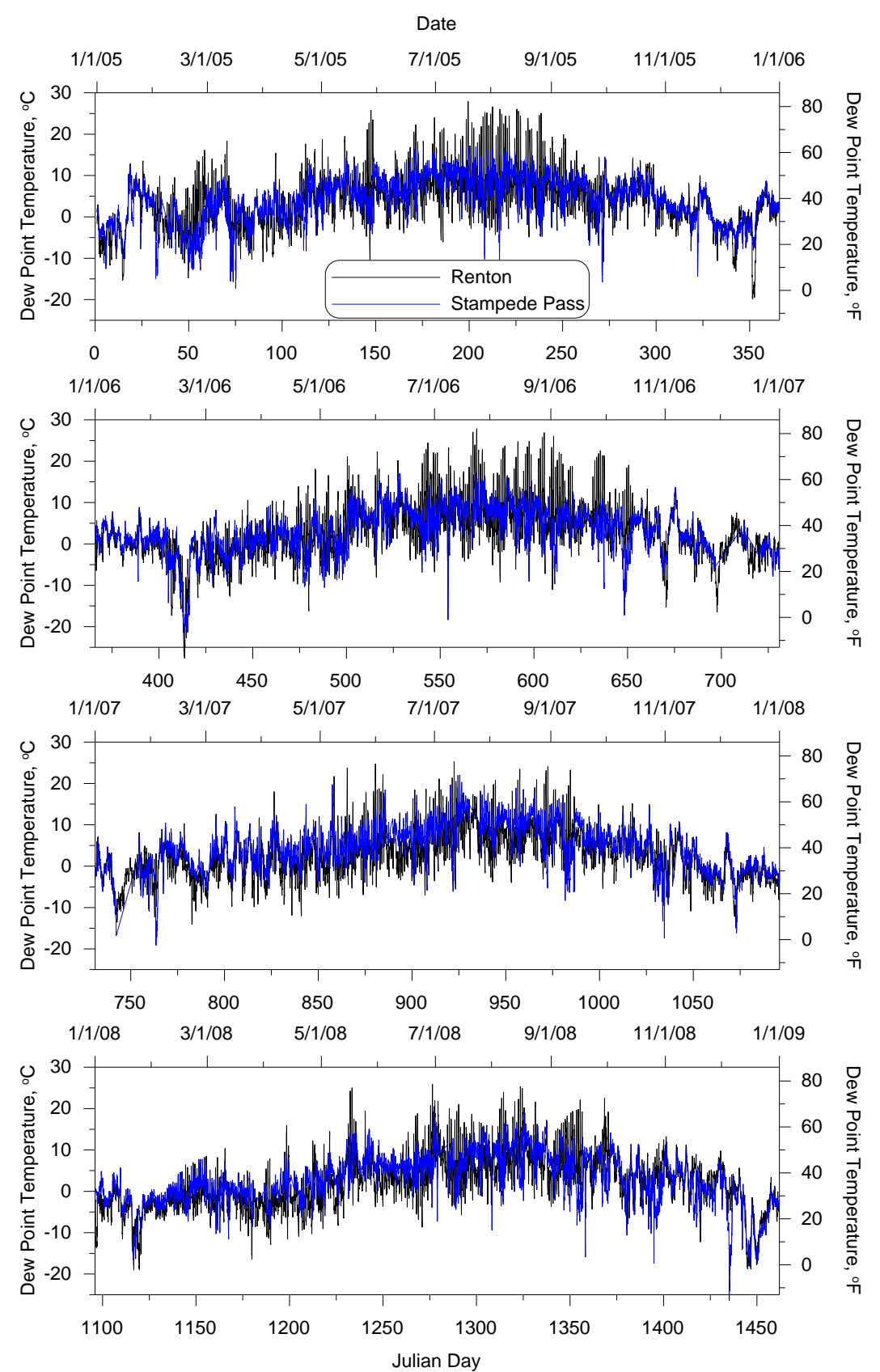

Figure 26. Dew point temperatures calculated using Renton (KRNT) and Stampede Pass (KSMP) relative humidity data

In the final calibration run, relative humidity data from Stampede Pass was used to calculate dew point temperature. This decision was made because the data tended to show less extreme (both high and low) swings than was observed in the Renton data. 


\section{Cloud Cover}

A summary of the cloud cover data over the model period from Renton and Stampede

Pass weather stations is shown in Figure 27.

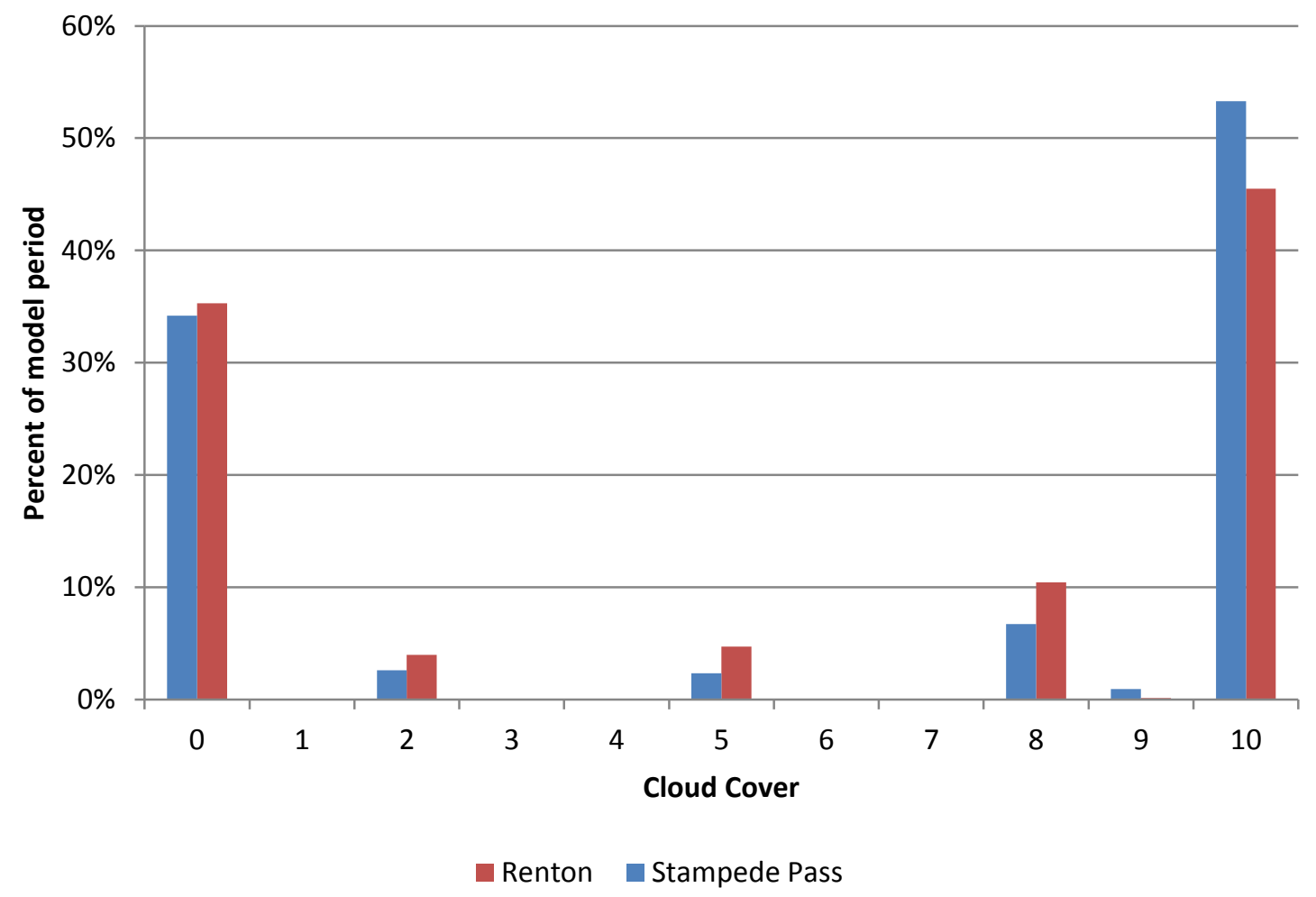

Figure 27. Renton (KRNT) and Stampede Pass (KSPM) cloud cover data

Cloud cover data from Stampede Pass was used in the final model calibration. Both data sets appeared to be very similar, but it was determined that because of its higher elevation mountain location, Stampede Pass might have cloud cover conditions more similar to Chester Morse Lake than Renton, which is located at sea level. 


\section{Solar Radiation}

Solar radiation was estimated using a theoretical solar radiation model developed in 1971 by the EPA. This model uses latitude and longitude, elevation, cloud cover, and Julian day to calculation solar radiation. For more details on this model, please see Annear and Wells (2007). 


\section{Boundary Condition Data}

\section{Chester Morse Lake Model Boundary Conditions}

\section{Model Inflows}

The Chester Morse Lake watershed, shown in Figure 28, covers an area of approximately 213 square kilometers. Three streams, the Cedar River, the Rex River and Boulder Creek, drain about $78 \%$ of the total area of the watershed. These three streams are monitored by a network of USGS stations a map of which is shown in Figure 29. The remaining 48 square kilometers drain into Chester Morse Lake by means of smaller ungauged streams. A summary of the catchment areas making up the Chester Morse Lake Watershed is shown in Table 8. This table indicates which streams drain into each of the three main gaged streams and well as which drain directly into Chester Morse Lake. The model segment number is listed to indicate where they enter the model.

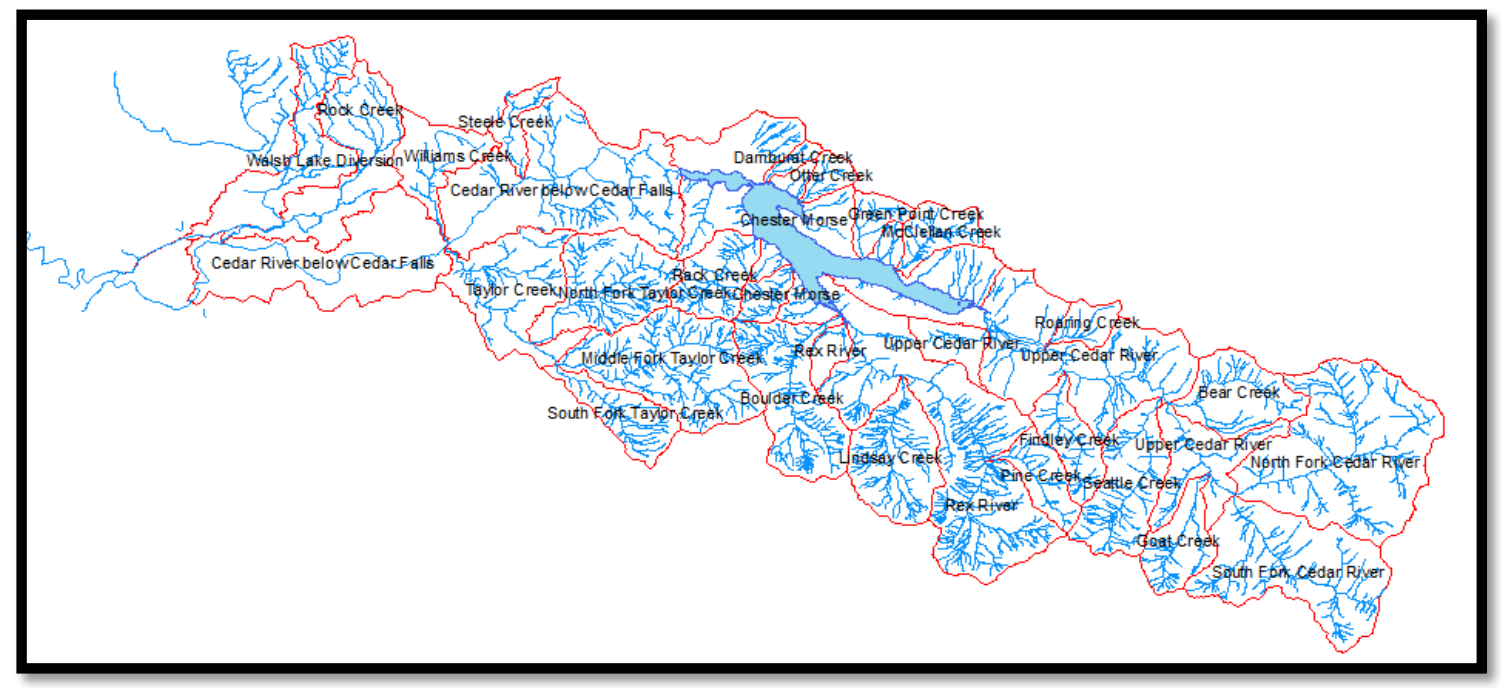

Figure 28. Chester Morse Lake catchment basin 


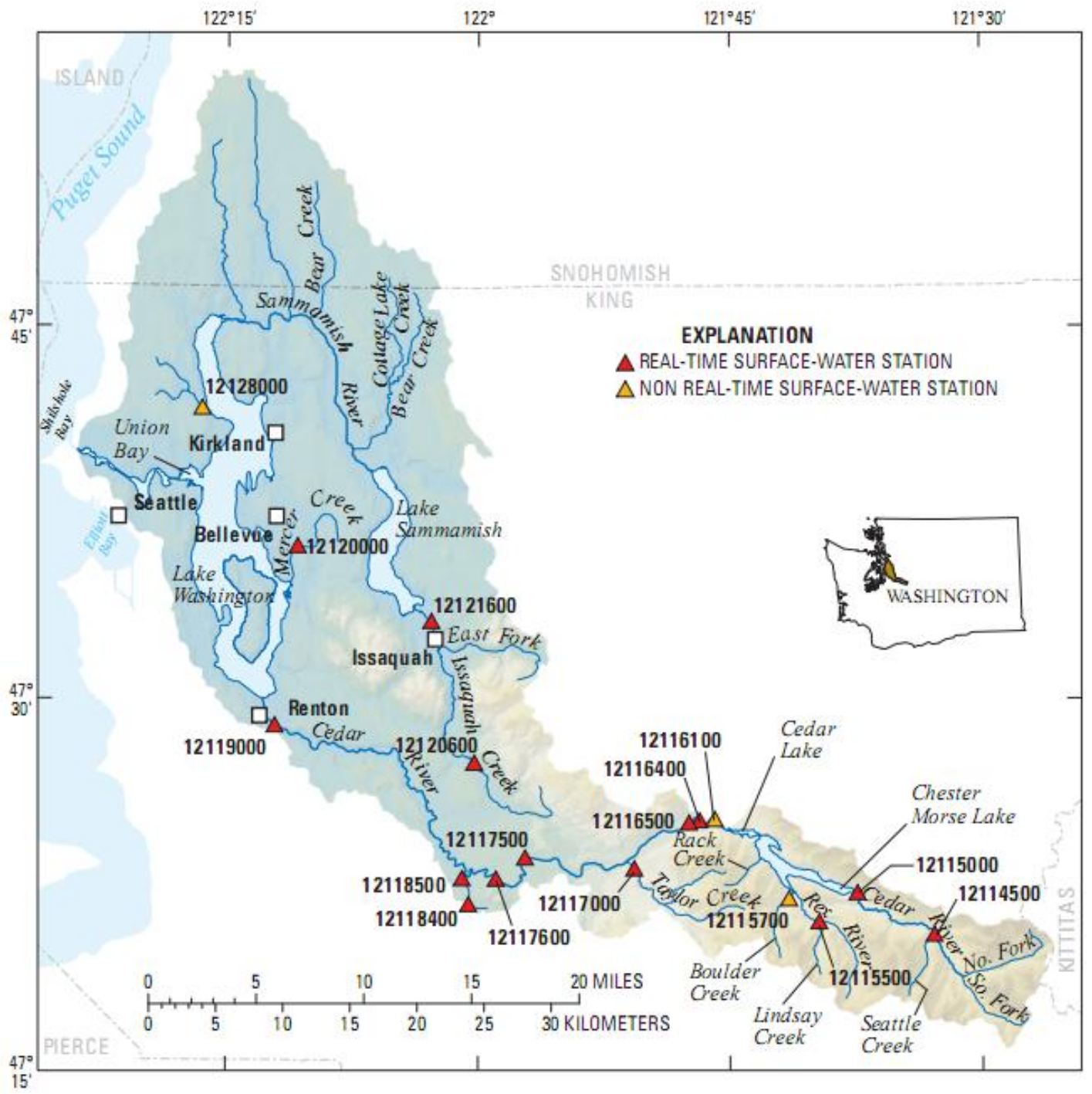

Figure 29. Lake Washington Basin Map (USGS, 2009) 
Table 8. Summary of catchment areas

\begin{tabular}{|c|c|c|c|c|c|c|}
\hline Catchment Area & $\begin{array}{c}\text { Area, square } \\
\text { feet }\end{array}$ & $\begin{array}{l}\text { Area, } \\
\text { acres }\end{array}$ & $\begin{array}{l}\text { Cedar } \\
\text { River }\end{array}$ & $\begin{array}{c}\text { Rex } \\
\text { River }\end{array}$ & $\begin{array}{l}\text { Boulder } \\
\text { Creek }\end{array}$ & $\begin{array}{c}\text { Lake Model } \\
\text { Segment }\end{array}$ \\
\hline Bear Creek & 84327890.37 & 1935.9 & $x$ & & & \\
\hline Boulder Creek & 132145933.1 & 3033.7 & & & $x$ & \\
\hline Chester Morse & 356799086.8 & 8191.0 & & & & Distributed \\
\hline Damburat Creek & 10977070.91 & 252.0 & & & & 37 \\
\hline Findley Creek & 53798791.83 & 1235.0 & $x$ & & & \\
\hline Goat Creek & 58005802.67 & 1331.6 & $x$ & & & \\
\hline Green Point Creek & 26628933.64 & 611.3 & & & & 19 \\
\hline Lindsay Creek & 107803858.3 & 2474.8 & & $x$ & & \\
\hline McClellan Creek & 40986148.89 & 940.9 & & & & 15 \\
\hline $\begin{array}{c}\text { North Fork Cedar } \\
\text { River }\end{array}$ & 283418051.6 & 6506.4 & $x$ & & & \\
\hline Otter Creek & 19066338.85 & 437.7 & & & & 51 \\
\hline Pine Creek & 45644425.98 & 1047.9 & & $x$ & & \\
\hline Rack Creek & 62353692.29 & 1431.4 & & & & 32 \\
\hline Rex River & 354886747.8 & 8147.1 & & $x$ & & \\
\hline Roaring Creek & 25499162.2 & 585.4 & $x$ & & & \\
\hline Seattle Creek & 104424277.1 & 2397.3 & $x$ & & & \\
\hline $\begin{array}{c}\text { South Fork Cedar } \\
\text { River }\end{array}$ & 192435765.3 & 4417.7 & $x$ & & & \\
\hline Upper Cedar River & 335106666.7 & 7693.0 & $x$ & & & \\
\hline
\end{tabular}

In order to estimate the flow into Chester Morse Lake from ungauged streams, it was necessary to perform a regression analysis based upon the total area of each catchment basin for which flow data were available. The average yearly flow from each basin was correlated to basin size. A summary of the regression statistics is shown in Table 9. This regression assumed that average precipitation was constant over the whole watershed. A simple relationship was developed between each creek's drainage area and its flow as a percentage of flow recorded in the Cedar River. 
Table 9. Flow Regression Statistics

\begin{tabular}{lr}
\hline \multicolumn{2}{c}{ Regression Statistics } \\
\hline Multiple R & 0.9966 \\
R Square & 0.9932 \\
Adjusted R Square & 0.4932 \\
Standard Error & 0.4812 \\
Observations & 3 \\
\hline & \\
\hline & Coefficients \\
\hline Intercept & 0 \\
X Variable 1 & 0.07083 \\
\hline
\end{tabular}

Table 10 shows a summary of the results of this analysis.

Table 10. Summary of area based regression to calculate minor tributary inflows to Chester Morse Lake

\begin{tabular}{|c|c|c|c|c|c|}
\hline Inflow & $\begin{array}{c}\text { Total } \\
\text { area, } \mathrm{ft}^{2}\end{array}$ & $\begin{array}{l}\text { Total } \\
\text { area, } \\
\mathrm{km}^{2}\end{array}$ & $\begin{array}{c}\text { Measured average } \\
\text { yearly discharge, } \\
\mathrm{m}^{3} / \mathrm{sec}\end{array}$ & $\begin{array}{l}\text { Calculated average } \\
\text { discharge using area } \\
\text { regression, } \mathrm{m}^{3} / \mathrm{sec}\end{array}$ & $\begin{array}{c}\% \text { of } \\
\text { Cedar } \\
\text { discharge }\end{array}$ \\
\hline $\begin{array}{c}\text { Cedar River (RM } \\
\text { 43.5) }\end{array}$ & $\begin{array}{c}1.14 \mathrm{E}+0 \\
9\end{array}$ & 105.63 & 7.77 & 7.48 & $100 \%$ \\
\hline Rex River & $\begin{array}{c}5.08 \mathrm{E}+0 \\
8 \\
\end{array}$ & 47.23 & 2.75 & 3.35 & $35 \%$ \\
\hline Boulder Creek & $\begin{array}{c}1.32 \mathrm{E}+0 \\
8\end{array}$ & 12.28 & 0.69 & 0.87 & $8 \%$ \\
\hline Damburat Creek & $\begin{array}{c}1.10 \mathrm{E}+0 \\
7\end{array}$ & 1.02 & Not measured & 0.07 & $1 \%$ \\
\hline Green Point Creek & $\begin{array}{c}2.66 \mathrm{E}+0 \\
7\end{array}$ & 2.47 & Not measured & 0.18 & $2 \%$ \\
\hline McClellan Creek & $\begin{array}{c}4.10 \mathrm{E}+0 \\
7\end{array}$ & 3.81 & Not measured & 0.27 & $3 \%$ \\
\hline Otter Creek & $\begin{array}{c}1.91 \mathrm{E}+0 \\
7\end{array}$ & 1.77 & Not measured & 0.13 & $2 \%$ \\
\hline Rack Creek & $\begin{array}{c}6.24 \mathrm{E}+0 \\
7\end{array}$ & 5.79 & Not measured & 0.41 & $5 \%$ \\
\hline $\begin{array}{c}\text { Chester Morse } \\
\text { Lake (Distributed) }\end{array}$ & $\begin{array}{c}3.57 \mathrm{E}+0 \\
8 \\
\end{array}$ & 33.15 & Not measured & 2.35 & $30 \%$ \\
\hline
\end{tabular}


Equation 2 illustrates how flow for each basin was calculated based upon its relative area and flow in the Cedar River.

$$
\begin{aligned}
& \text { Equation 2. Sample equation for Rack Creek for flow calculation } \\
& \qquad Q_{\text {Rack }}=Q_{\text {Cedar }} * 0.054
\end{aligned}
$$

The primary gaged inflows to Chester Morse Lake over the full model period are shown in Figure 30 and Figure 31. During periods of high reservoir water surface elevation (above $1560.5 \mathrm{ft}$ or $475.6 \mathrm{~m}$ ) the USGS Station 12115000 on the Cedar River is affected by backwater from Chester Morse Lake. The flows recorded at the USGS flow gage during these periods are much greater than actual flow in the Cedar River. To estimate more accurate flows during these periods, a simple regression was done between the Cedar River and the Rex River flows during other periods - when both flows were judged to be fairly accurate. This regression was then used to estimate Cedar River flows from known Rex River flows during these periods of uncertainty, which occurred in late spring or early summer of each model year. Equation 3 shows this relationship. In the graphs that follow both raw USGS flow data (dark blue) and the adjusted flow (light green) are shown.

Equation 3. Cedar flow calculation based on Rex River regression

$$
Q_{\text {Cedar }}=Q_{\text {Rex }} * 2.70
$$



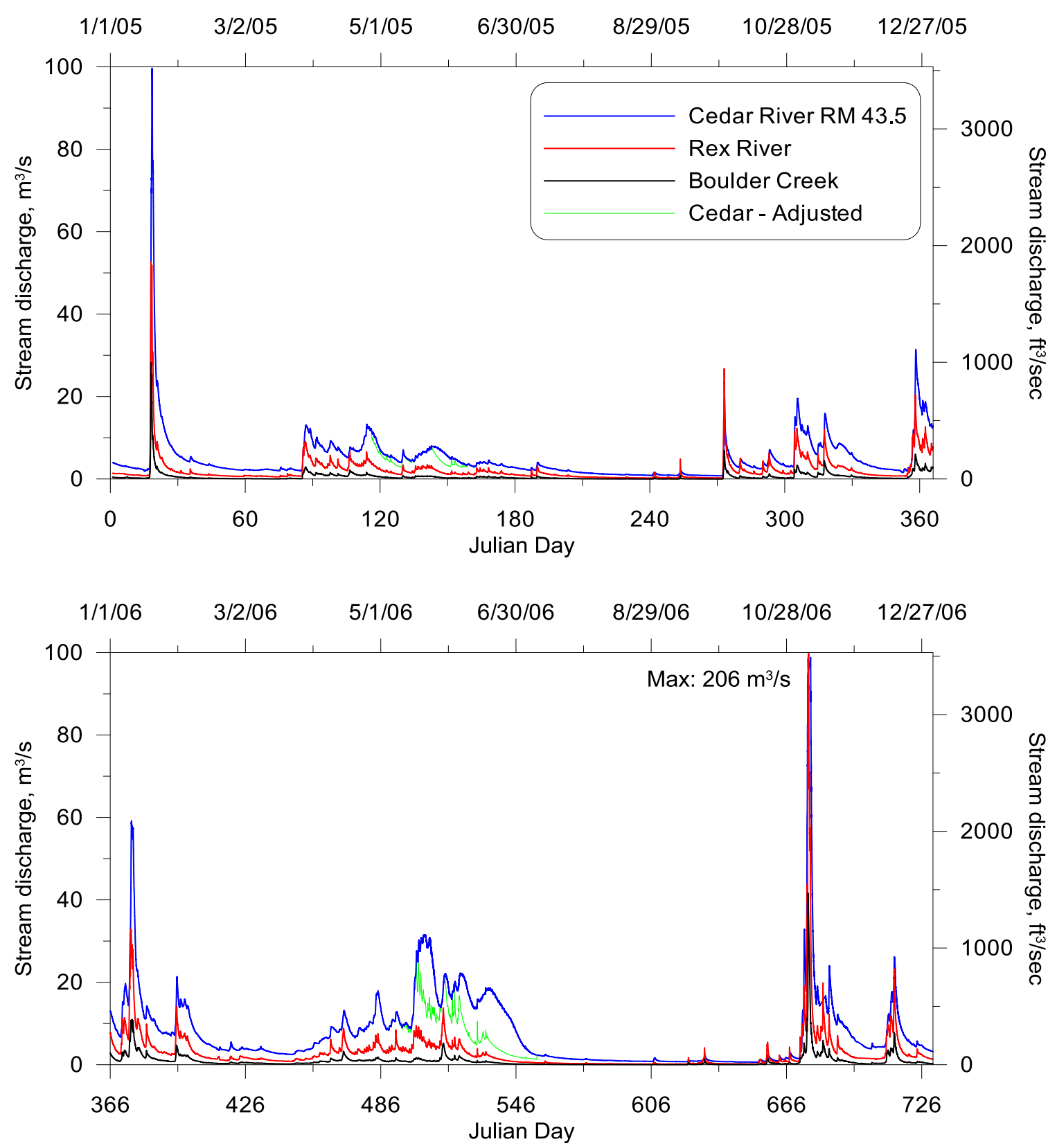

Figure 30. Gaged inflows into Chester Morse Lake (model years 1 and 2) 

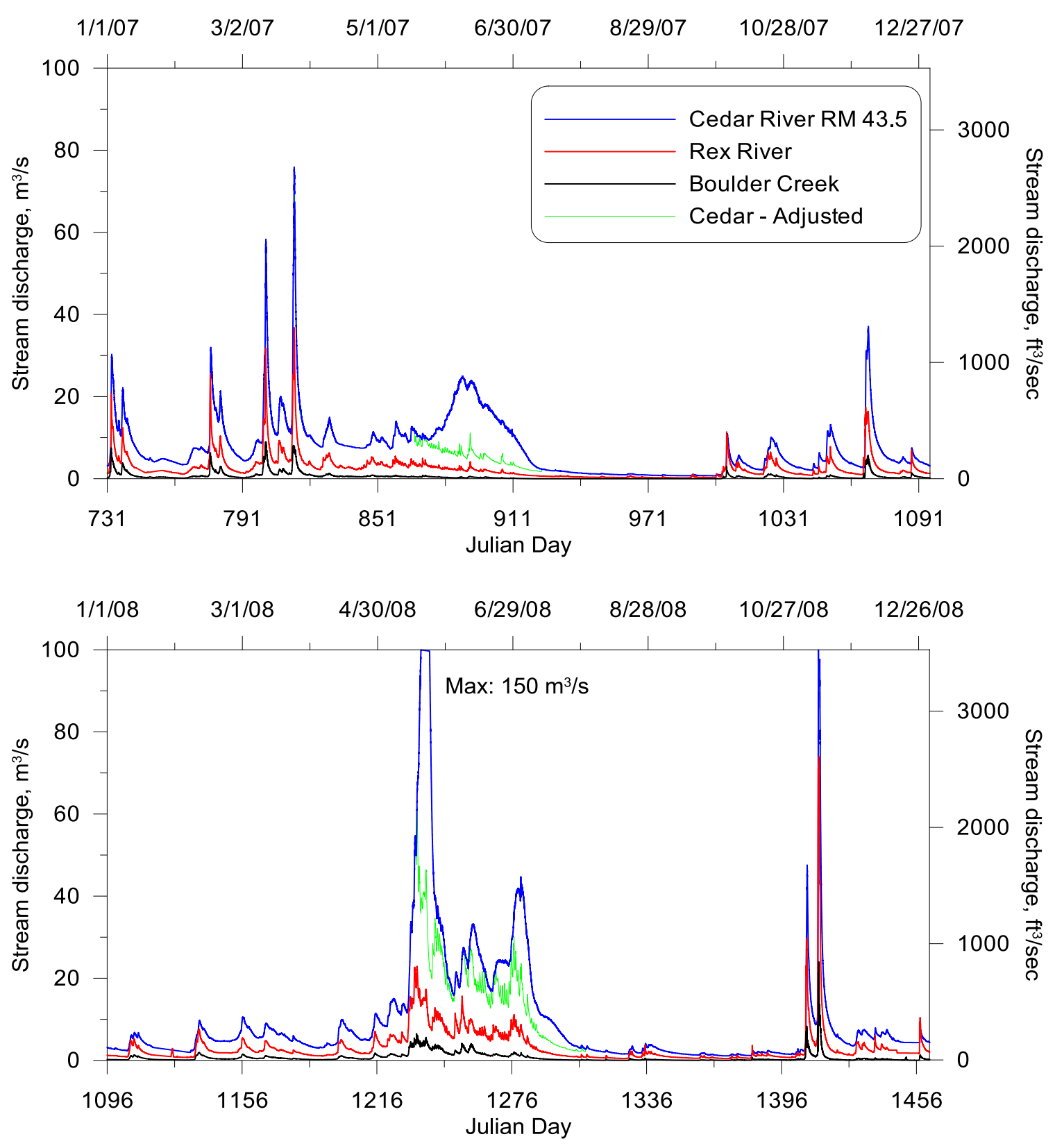

Figure 31. Gaged inflows into Chester Morse Lake (model years 3 and 4) 


\section{Inflow Temperature}

Water temperature data was available for the complete model period for the Cedar

River. Figure 32 shows a plot of recorded water temperatures at USGS station 12115000 on the Cedar River.
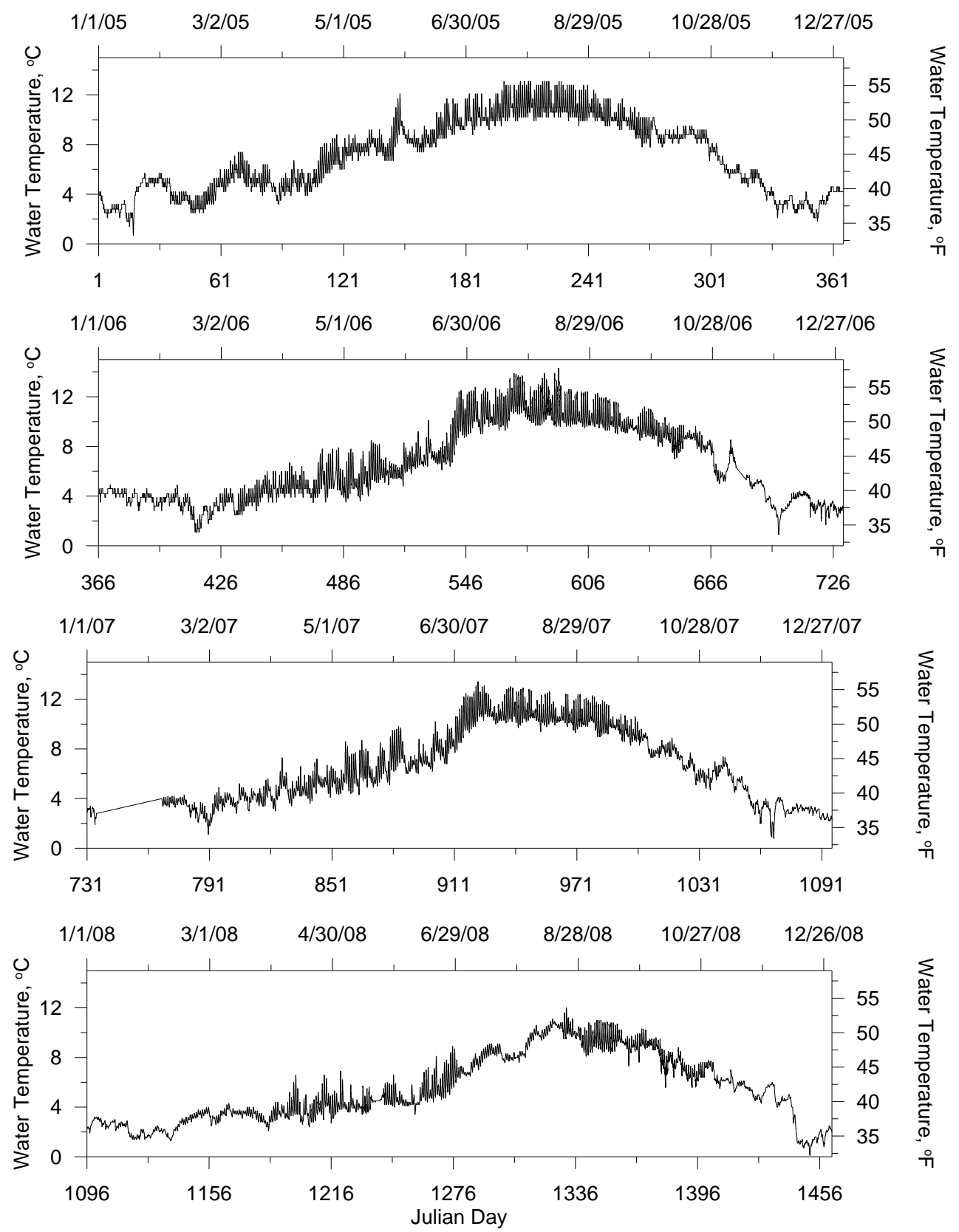

Figure 32. Cedar River water temperature (USGS 12115000) 
Only partial temperature records were available for Boulder Creek, the Rex River, and Rack Creek for this period. In order to fill gaps in the data, a regression was preformed between each stream's temperature and the water temperature recorded at the Cedar River over time periods when both data sets were available. Figure 33, Figure 34, and Figure 35 show the temperature regressions for Boulder Creek, the Rex River, and Rack Creek, respectively.

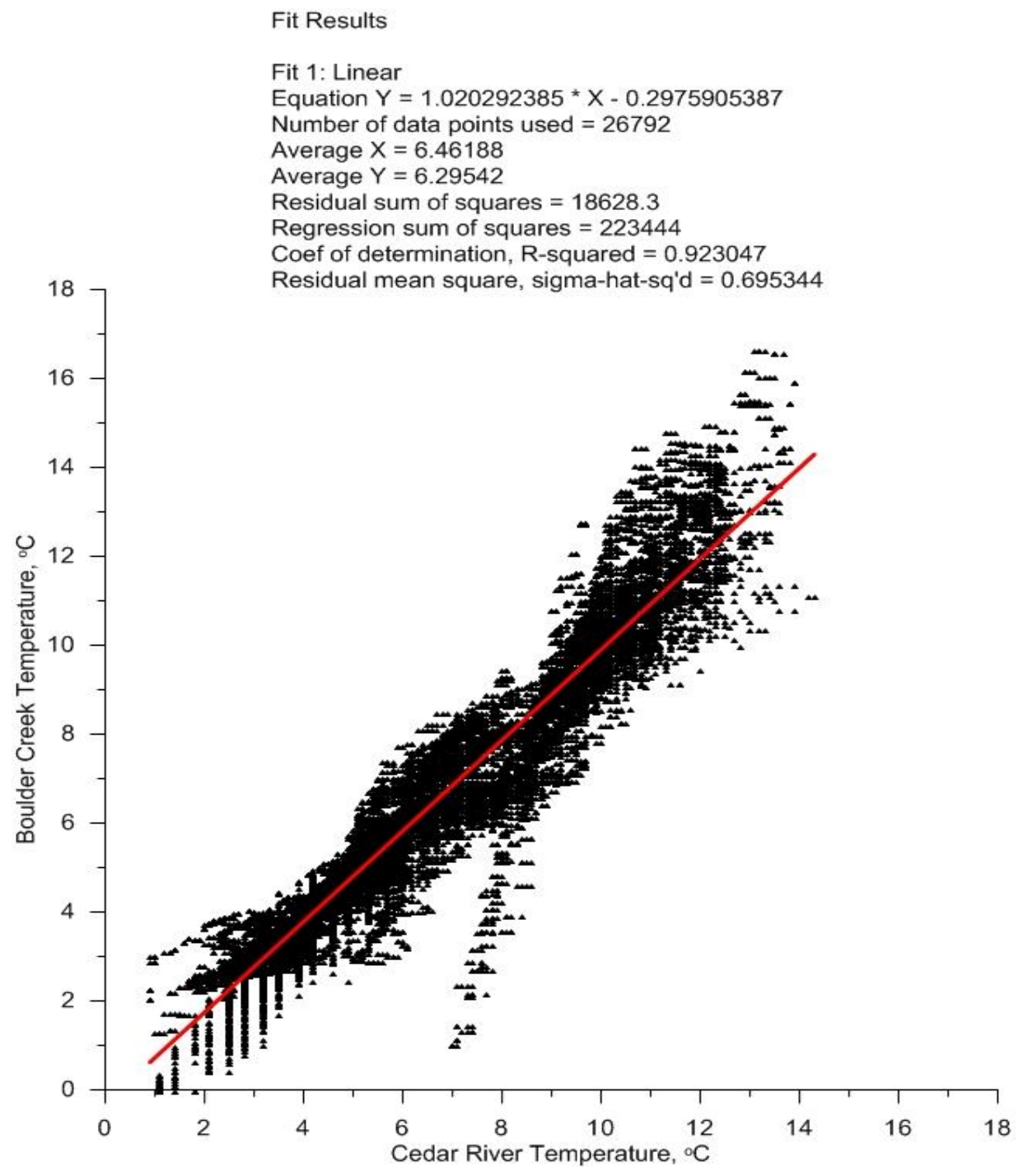

Figure 33. Boulder Creek - Cedar River temperature regression 
Fit Results

Fit 2: Linear

Equation $\mathrm{Y}=1.319517343{ }^{*} \mathrm{X}-1.901021769$

Number of data points used $=38534$

Average $X=6.11586$

Average $Y=6.16896$

Residual sum of squares $=26262.7$

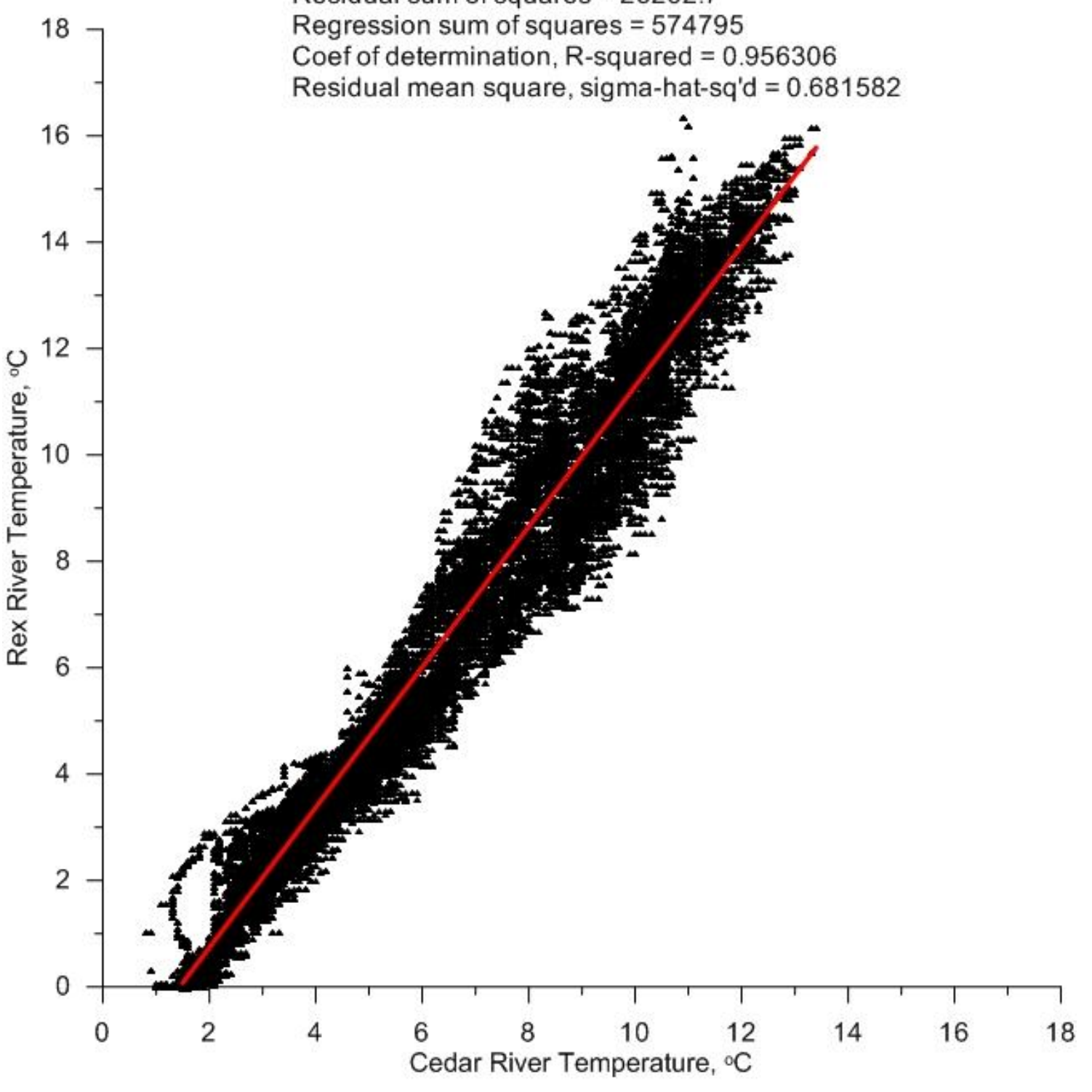

Figure 34. Rex River - Cedar River temperature regression 


\section{Fit Results}

Fit 1: Linear

Equation $Y=0.815197552 * X+1.217382604$

Number of data points used $=29168$

Average $X=6.93325$

Average $Y=6.86935$

Residual sum of squares $=12579.6$

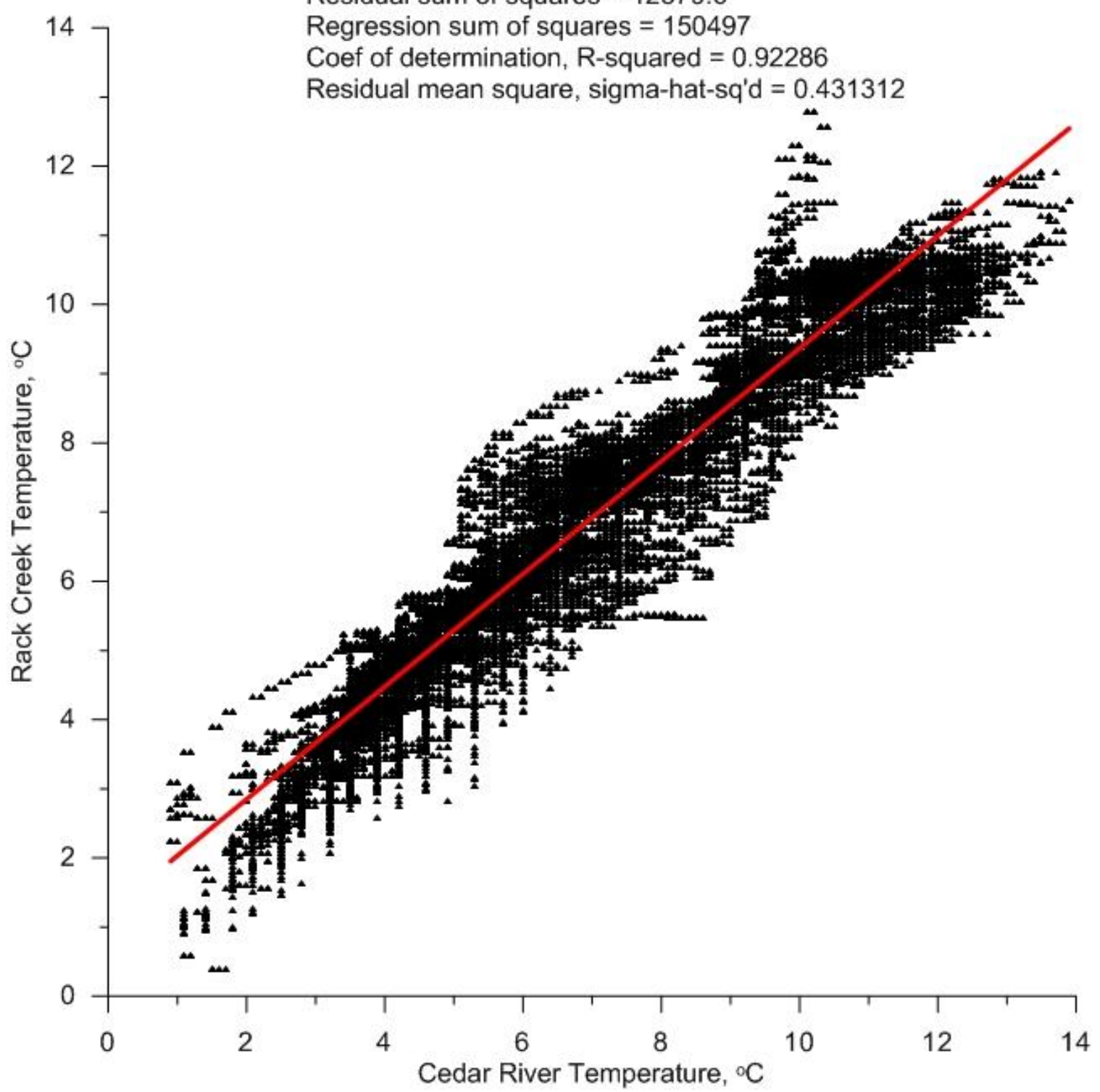

Figure 35. Rack Creek - Cedar River temperature regression 
Final temperature input files for each tributary include directly measured water temperature when available and estimated temperature based on the Cedar River water temperature regression when data are not available. An example of this is shown for Rack Creek in Figure 36.
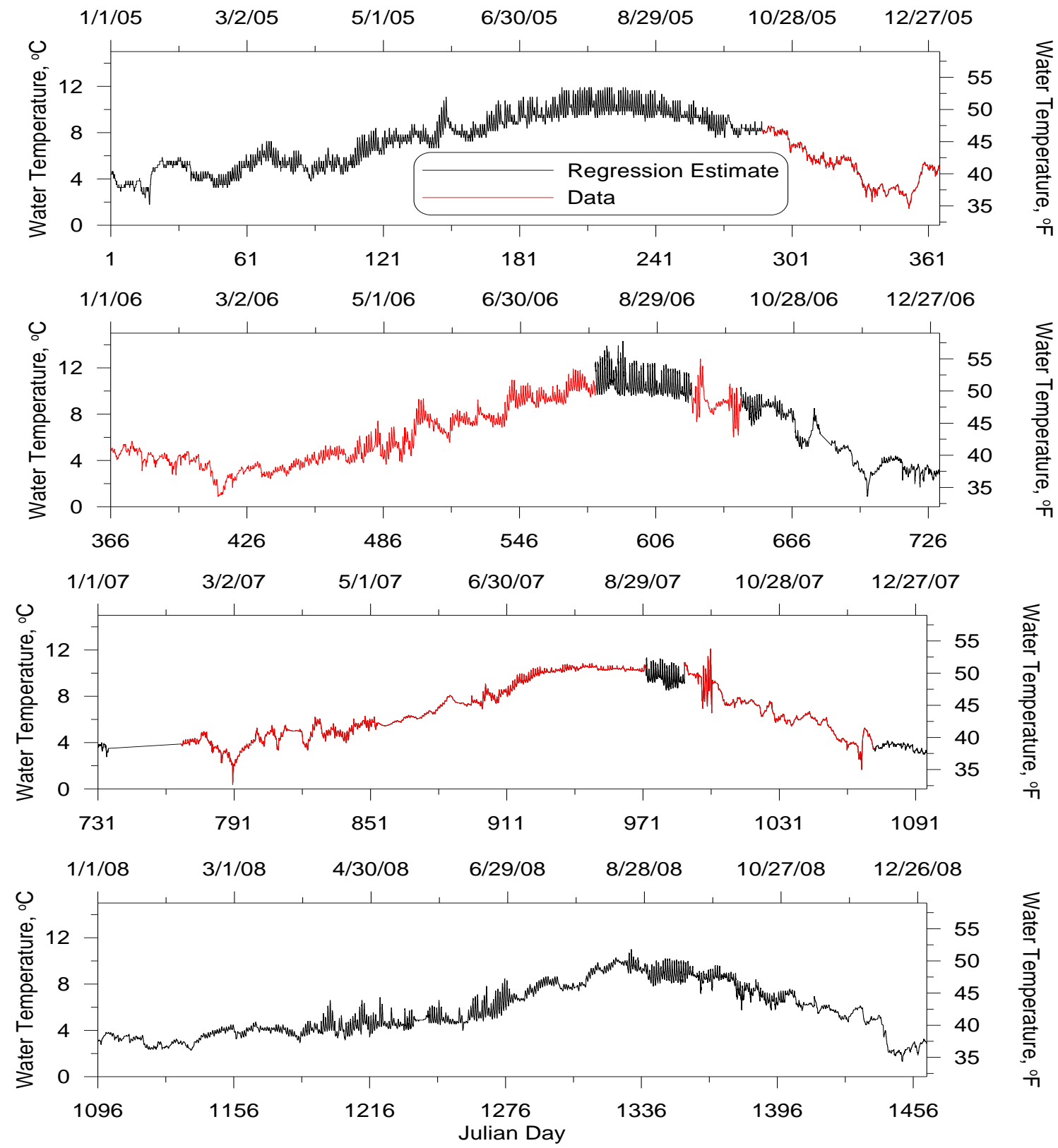

Figure 36. Rack Creek temperature input file 


\section{Model Outflow}

The two main outflows from Chester Morse Lake are releases through the Masonry Dam into the Cedar River and seepage loss to groundwater. Figure 37 plots the stream discharge downstream from Chester Morse Lake over the model period.
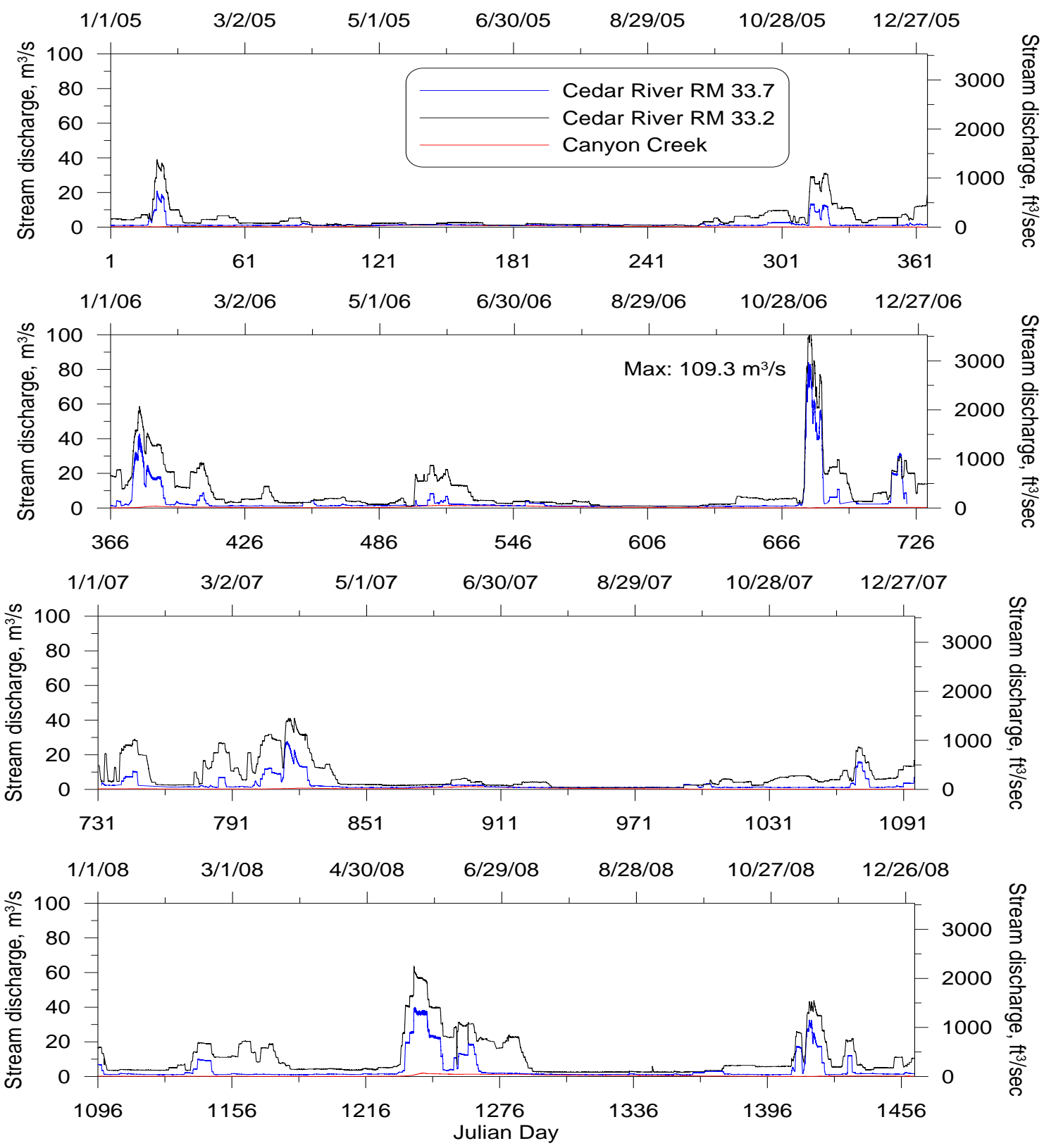

Figure 37. Stream discharge downstream of Chester Morse Lake over model period 
No direct measurements of discharge through the powerhouse, lower outlet release or spillway of the Masonry Dam were made available for modeling purposes. Because these releases draw water from different elevations in the water column, they are essential to capturing the temperature dynamics of the water behind the dam and in the stream below. In order to estimate the magnitude of each discharge, several simplifying assumptions were made. The magnitude of the powerhouse discharge was assumed to be the difference in discharge measured at stations USGS 12116500 and USGS 12116400 located on the Cedar River. The USGS schematic shown in Figure 38 indicates that the flow from the powerhouse is returned to the Cedar River at some point between these two stations.

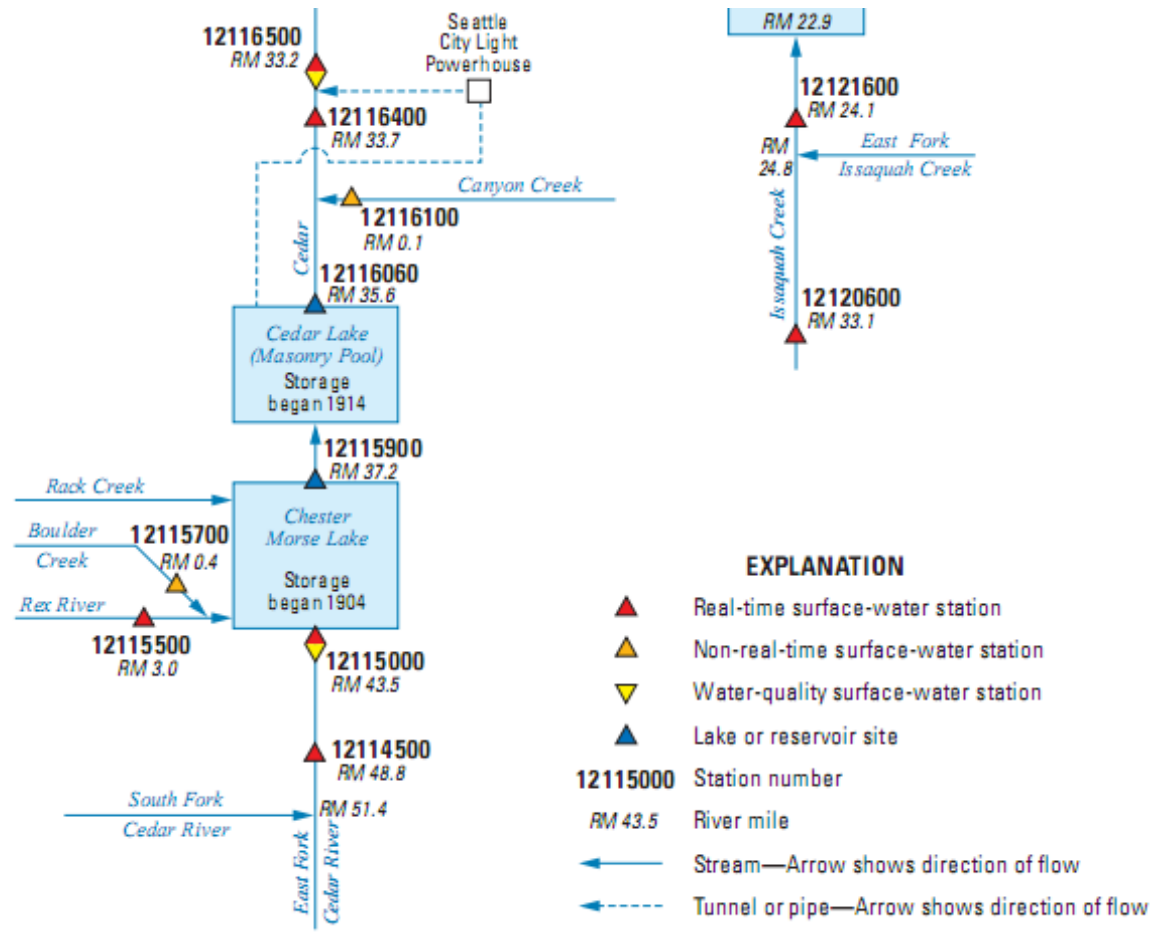

Figure 38. Lake Washington Basin schematic (USGS, 2009) 
The discharge from the lower outlet release of the Masonry dam was assumed to be the flow measured at USGS 12116400 minus the flow measured in Canyon Creek USGS 12116100, which enters the river downstream of the dam. According to schematics provided to us of the Masonry Dam, the maximum flow that can be discharged through the lower release outlet is 18.4 cubic meters per second. Any flows that exceeded this were assumed to pass over the spillway. The resulting partitioning of flow between the powerhouse, lower outlet release, and spillway over the model period is plotted in Figure 39.

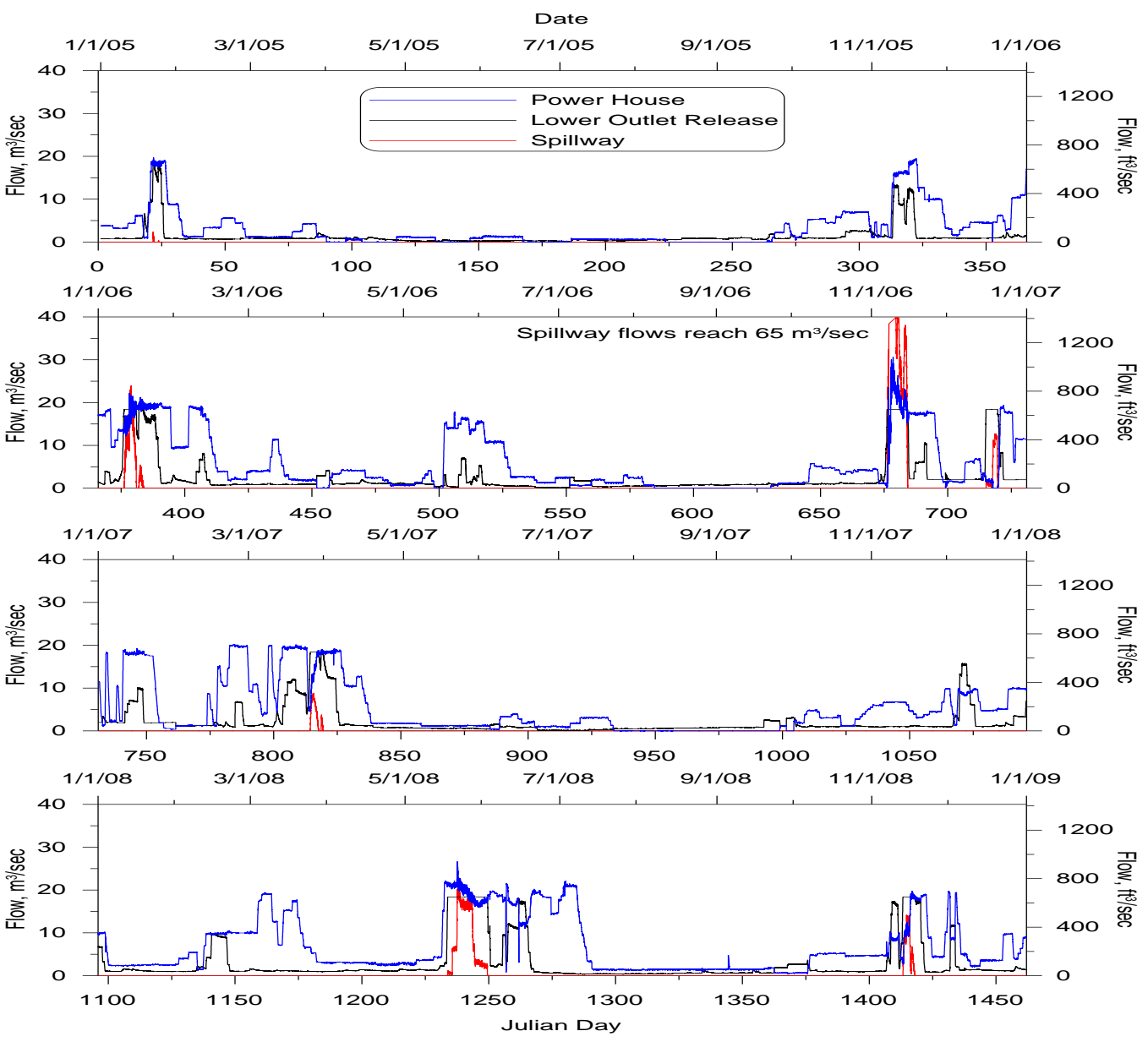

Figure 39. Calculated model outflows 


\section{Cedar River Boundary Conditions}

\section{Model Inflows}

There are 5 main gaged inflows to the Cedar River: the low level outlet from Chester

Morse Lake, powerhouse flow, spillway flow, and flow from two gaged tributaries,

Canyon Creek and Taylor Creek. The flows for these river model inflows are shown in

Figure 40. Additionally there are 3 ungauged tributaries that flow into the Cedar River below Cedar Falls: Steele Creek, Williams Creek, and Rock Creek.

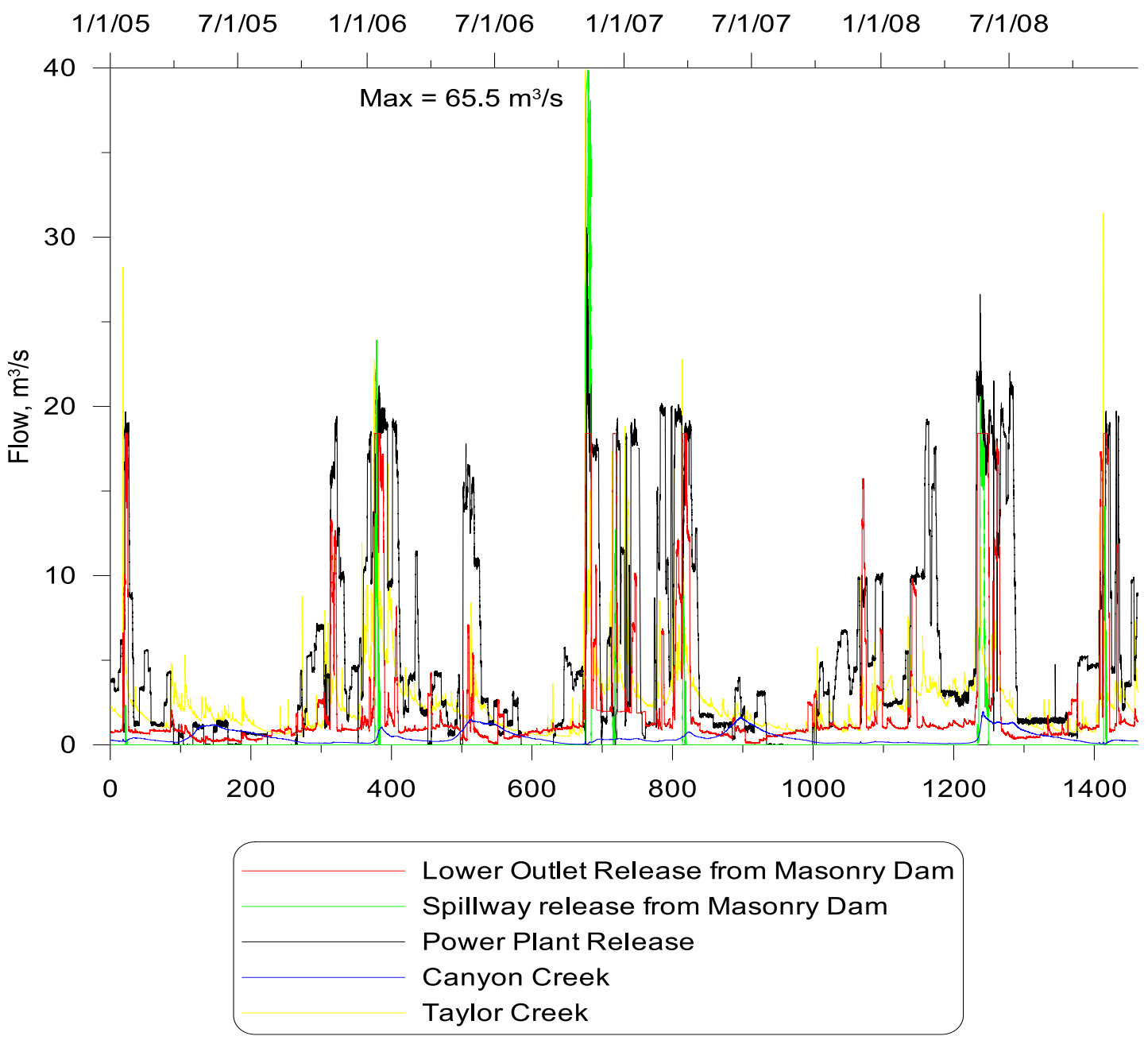

Figure 40. Cedar River model gaged inflows 


\section{Inflow Temperatures}

Chester Morse Lake model outflow temperatures were used to estimate the inflow temperatures for the three inflows originating from Chester Morse Lake - the lower level outlet flow, spillway flow, and powerhouse flow. Because these flows are drawn from different elevations behind the dam, the temperature of these flows varies, an example of which is shown in Figure 41 . The flat line seen in spillway flow temperatures indicates periods of zero flow.

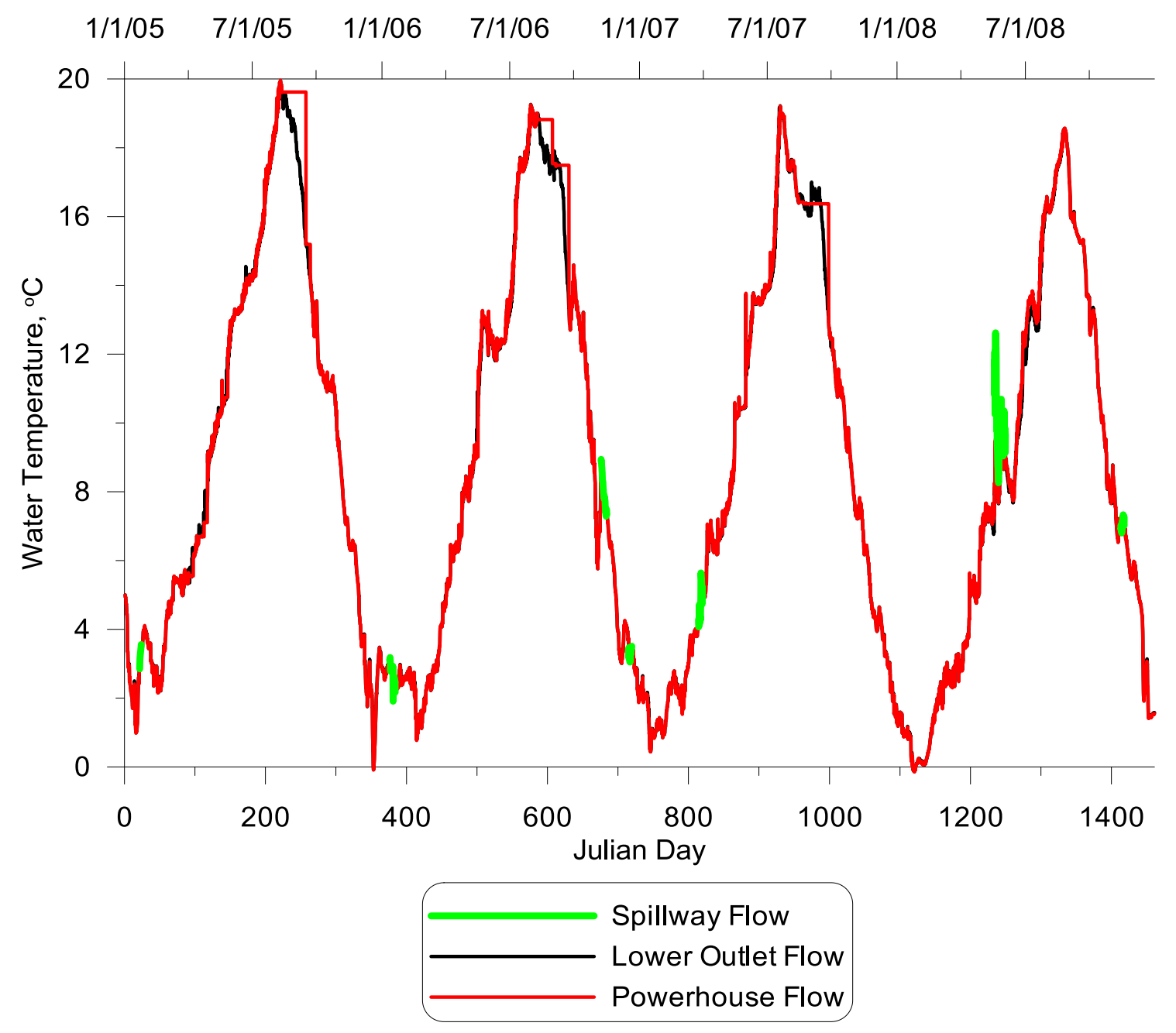

Figure 41. Chester Morse Lake model Masonry Dam outflow temperatures 
The temperatures of Canyon Creek, Taylor Creek and the other ungauged tributaries was estimated using the Cedar River temperatures from above Chester Morse Lake, due to this being the most complete local dataset available. 


\section{Temperature Calibration Data}

\section{In-Lake Temperature Data}

Extensive temperature data was collected in Chester Morse Lake during the period of model calibration. These data included time-series data collected at various buoy locations and depths, as well as temperature profiles collected near the center of the lake and near the Masonry Dam. These data were not used as direct model input but were instead used to calibrate the temperature model, as discussed in subsequent sections.

\section{Time-series Data}

Seven buoys were deployed with temperature probes at various depths throughout Chester Morse Lake in December of 2007. The buoys were anchored to the lake bottom; however their exact locations were impacted by changing wind conditions on the lake. Figure 42 shows the approximate location of the 7 buoys. Table 11 lists the buoy names, locations, and depths. 


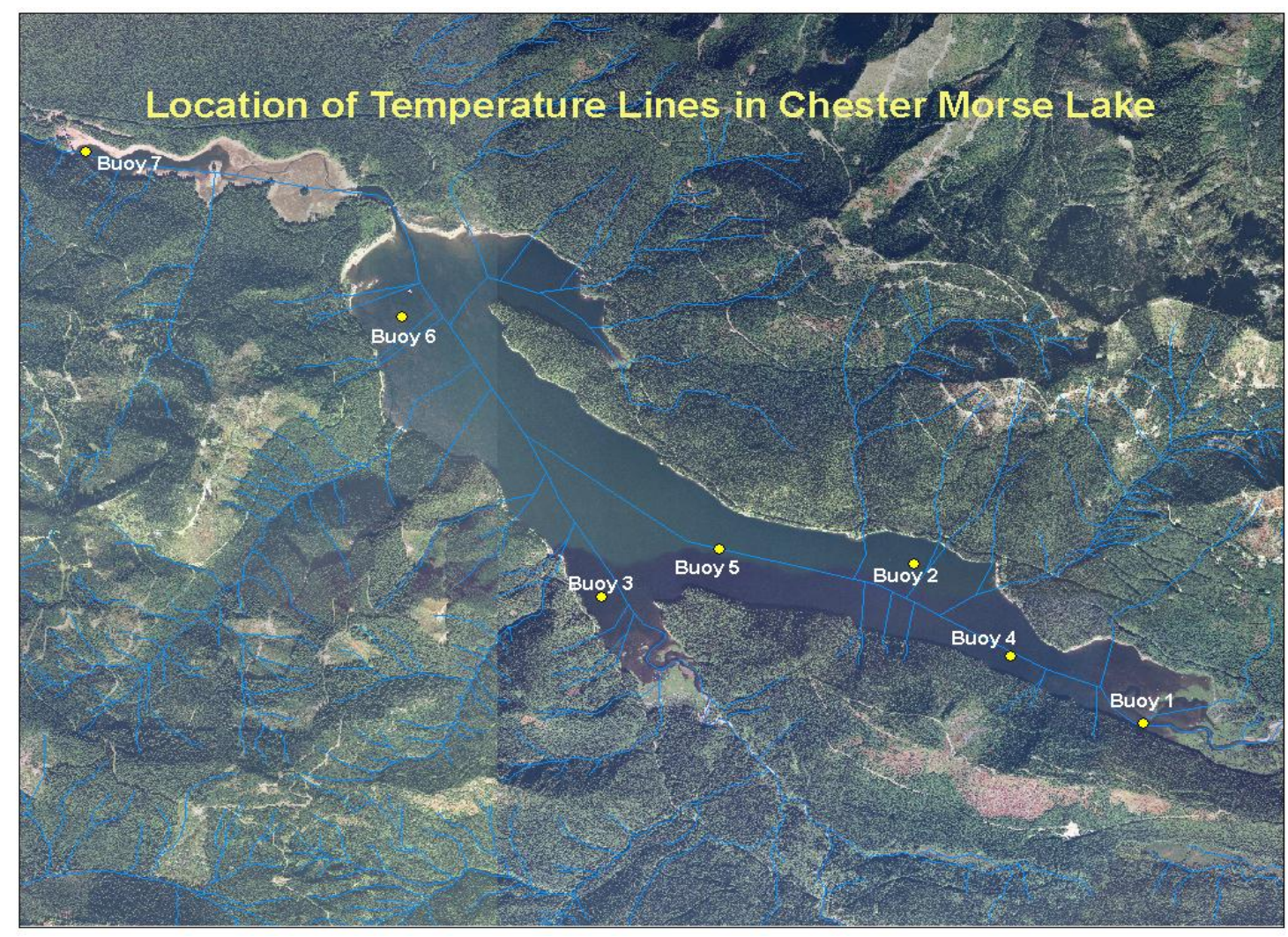

Figure 42. Location of temperature probes, buoys 1-7 (Paige, 2009)

Table 11. Temperature buoy details

\begin{tabular}{|c|l|c|c|}
\hline Buoy \# & \multicolumn{1}{|c|}{ Buoy Location } & $\begin{array}{c}\text { Maximum Depth, } \\
\text { m }\end{array}$ & Date Range \\
\hline $\mathbf{1}$ & Confluence with Cedar River & 4 & $12 / 19 / 2007-$ \\
& & & $5 / 29 / 2009$ \\
\hline $\mathbf{2}$ & Green Point/ McClellan & 25 & $12 / 19 / 2007-$ \\
& inflow & & $5 / 29 / 2009$ \\
\hline $\mathbf{3}$ & Rex Delta Drop-off & 25 & $12 / 19 / 2007-$ \\
& & & $5 / 29 / 2009$ \\
\hline $\mathbf{4}$ & Cedar Delta Drop-off & 35 & $12 / 19 / 2007-$ \\
& & & $5 / 29 / 2009$ \\
\hline $\mathbf{5}$ & Chester Morse Lake Deepest & 35 & $12 / 19 / 2007-$ \\
& & & $5 / 29 / 2009$ \\
\hline $\mathbf{6}$ & MLPP Intake & 25 & $12 / 19 / 2007-$ \\
& & & $5 / 29 / 2009$ \\
\hline $\mathbf{7}$ & Masonry Dam (in Masonry & 20 & $12 / 19 / 2007-$ \\
& Pool) & & $5 / 29 / 2009$ \\
\hline
\end{tabular}


The temperature data collected at these 7 buoys is shown in the following graphs.

Figure 43, Figure 44, Figure 45, Figure 46, Figure 47, Figure 48, and Figure 49 display data collected between $12 / 19 / 07$ and 5/28/09 at buoys 1 through 7 , respectively.

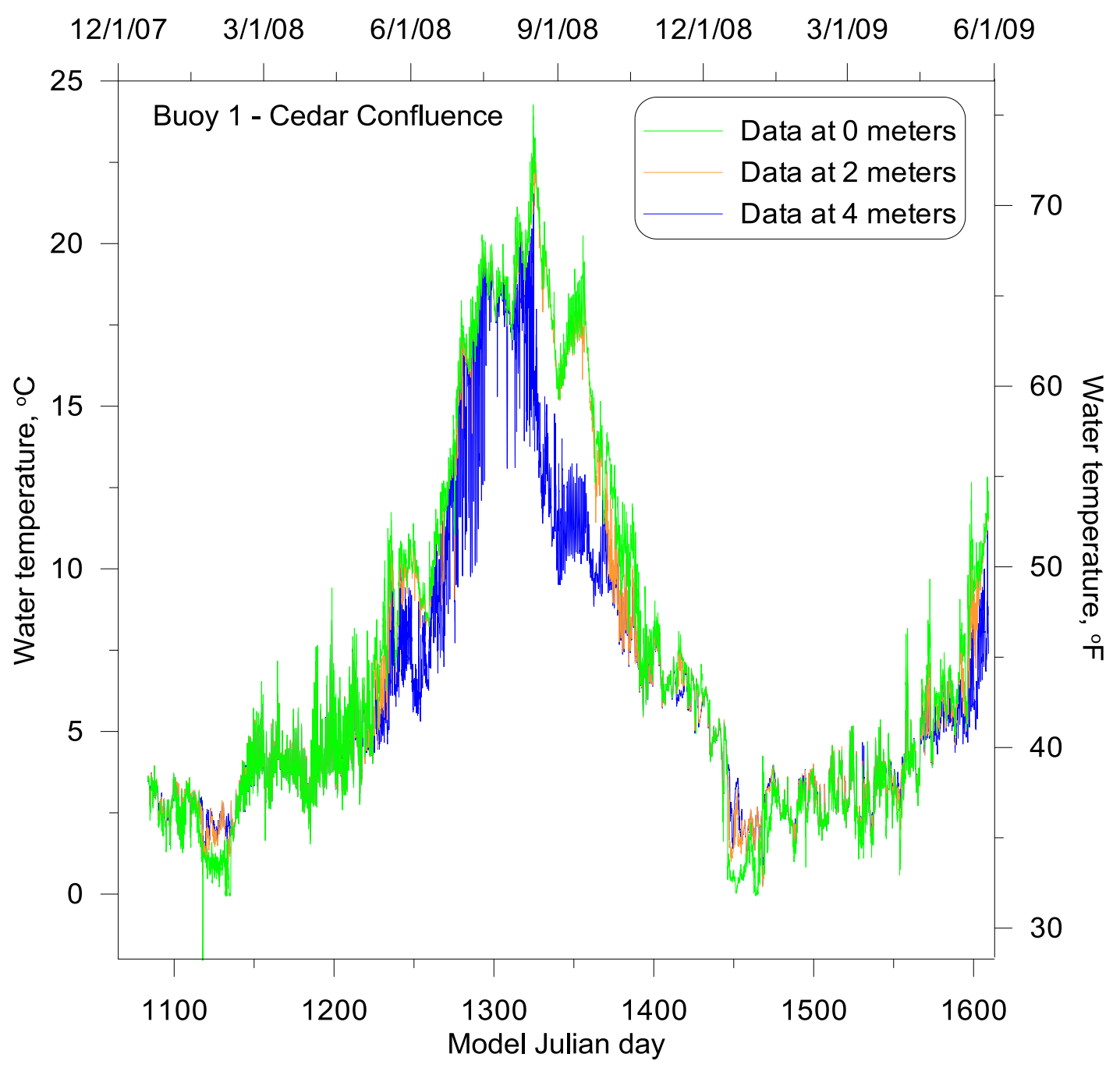

Figure 43. Time series temperature data collected at Buoy 1 (corresponding to model segment 9) 


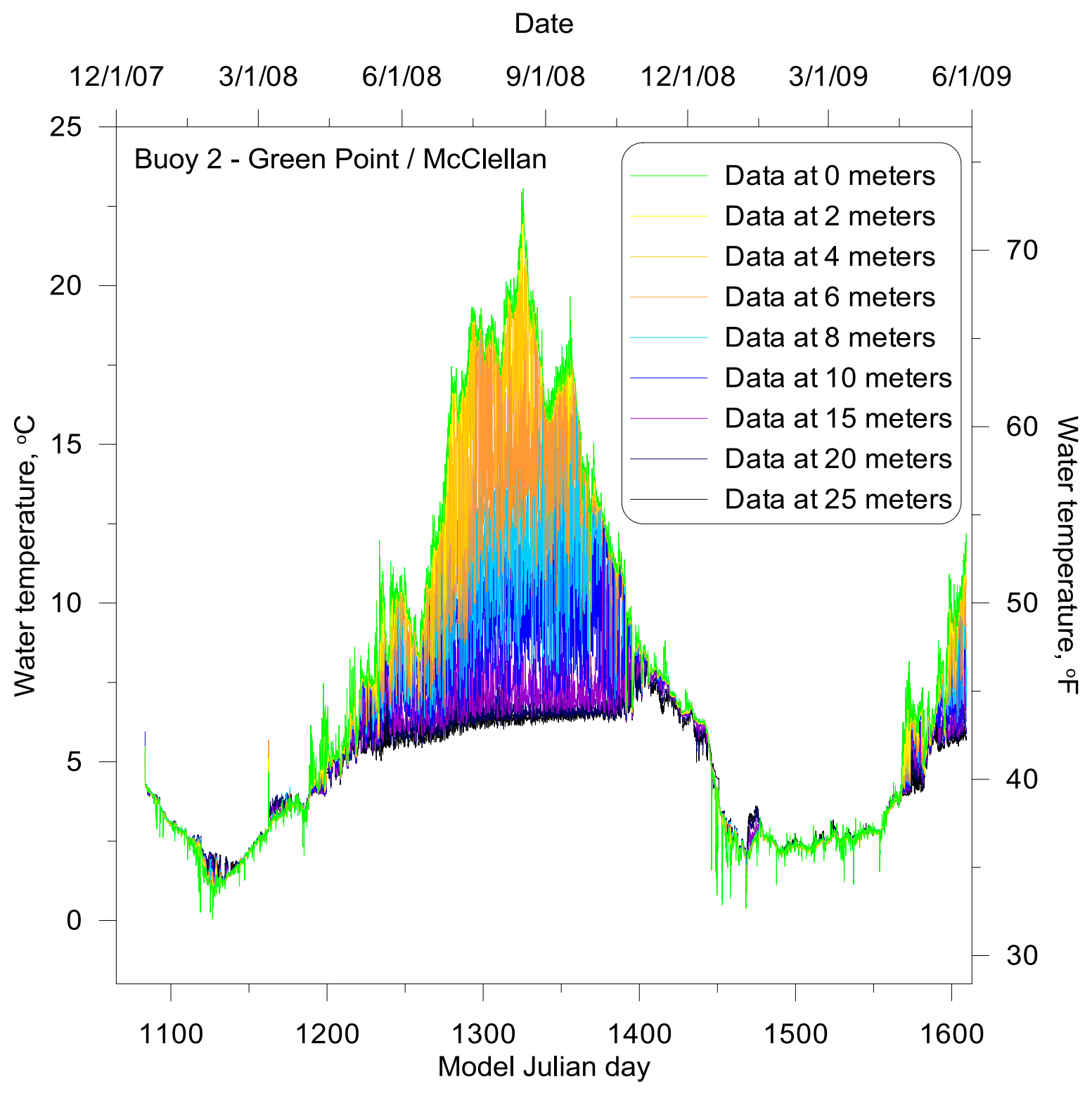

Figure 44. Time series temperature data collected at Buoy 2 (corresponding to model segment 17) 


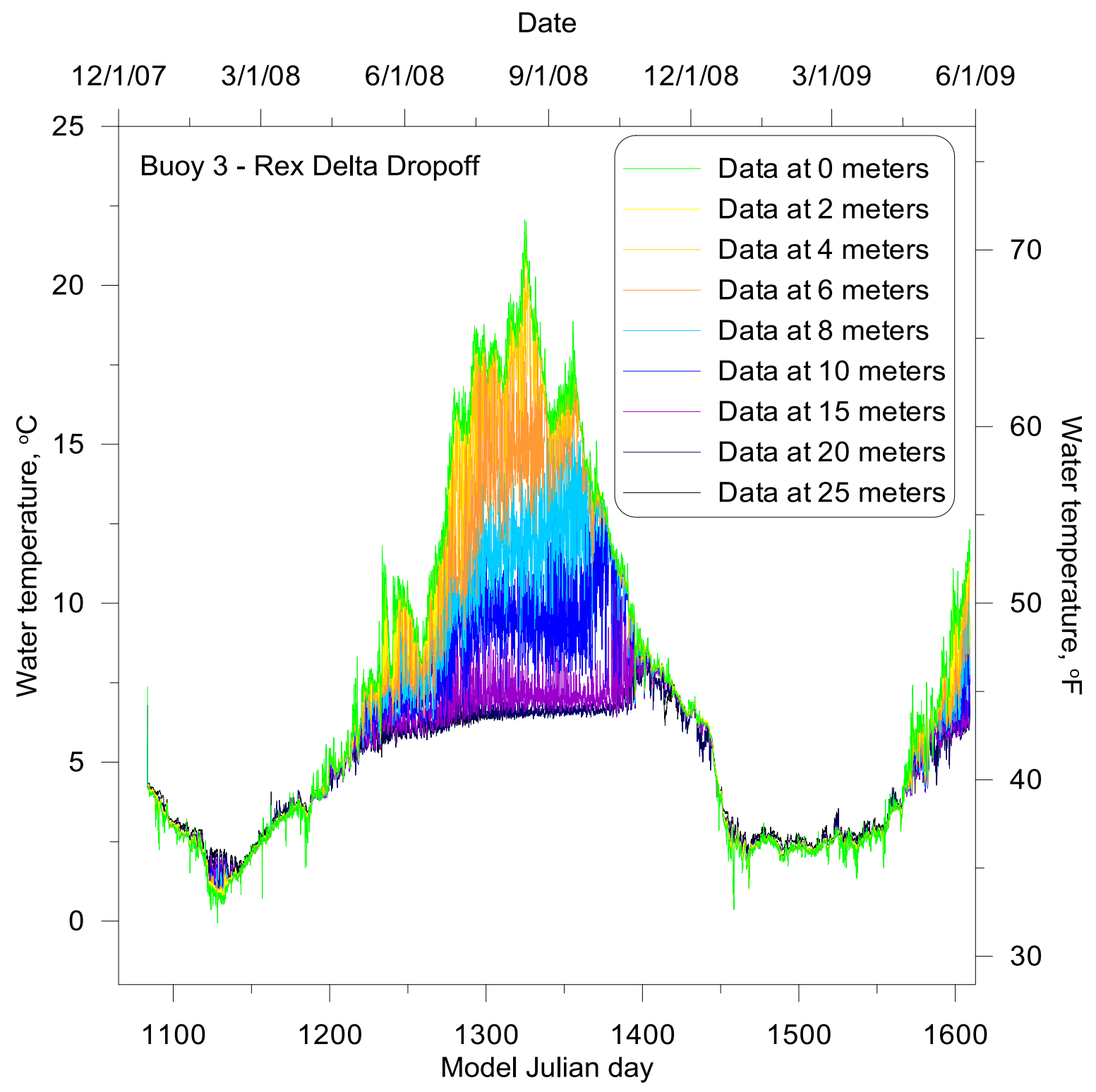

Figure 45. Time series temperature data collected at Buoy 3 (corresponding to model segment 47) 


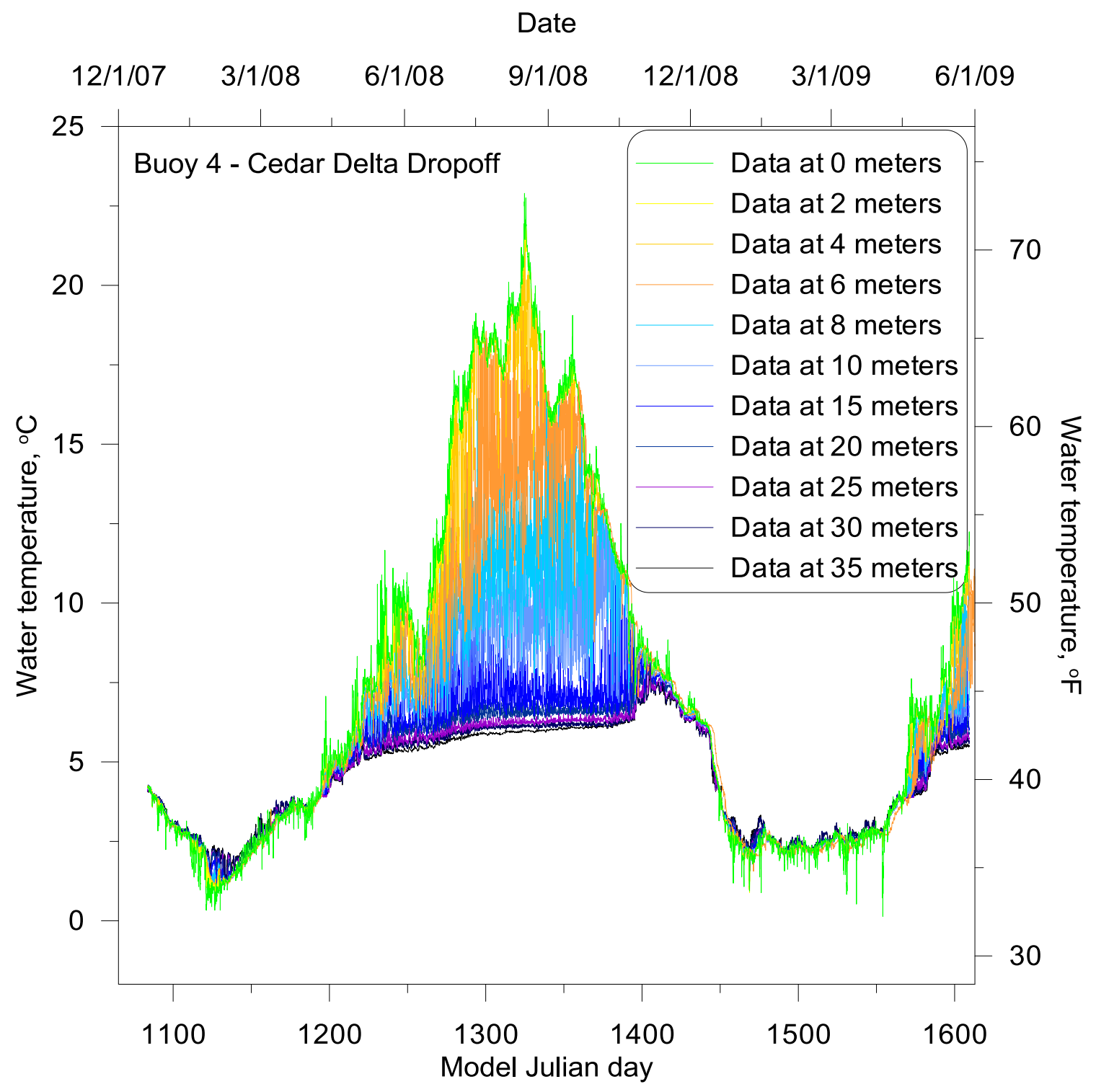

Figure 46. Time series temperature data collected at Buoy 4 (corresponding to model segment 13) 


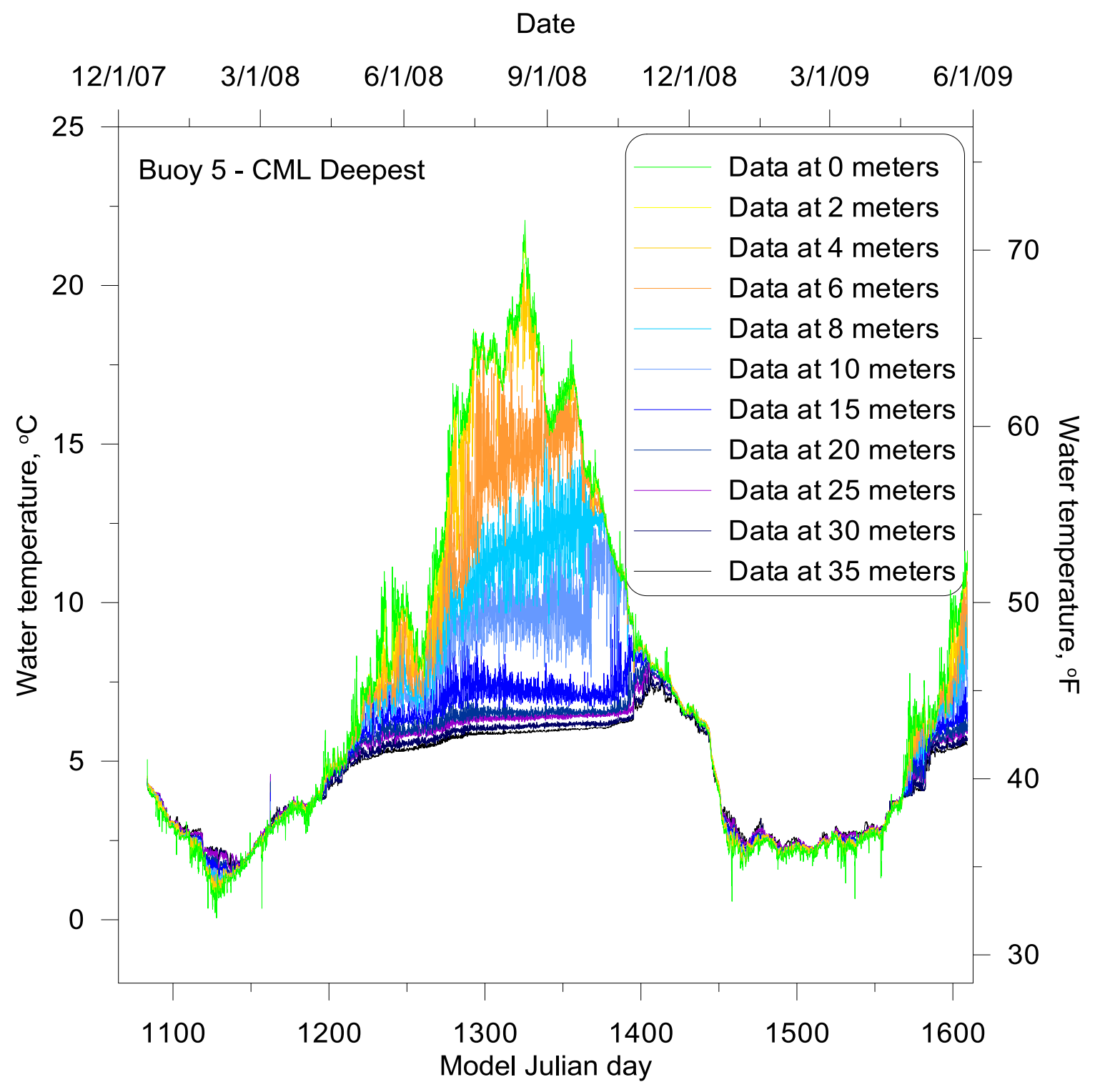

Figure 47. Time series temperature data collected at Buoy 5 (corresponding to model segment 23) 


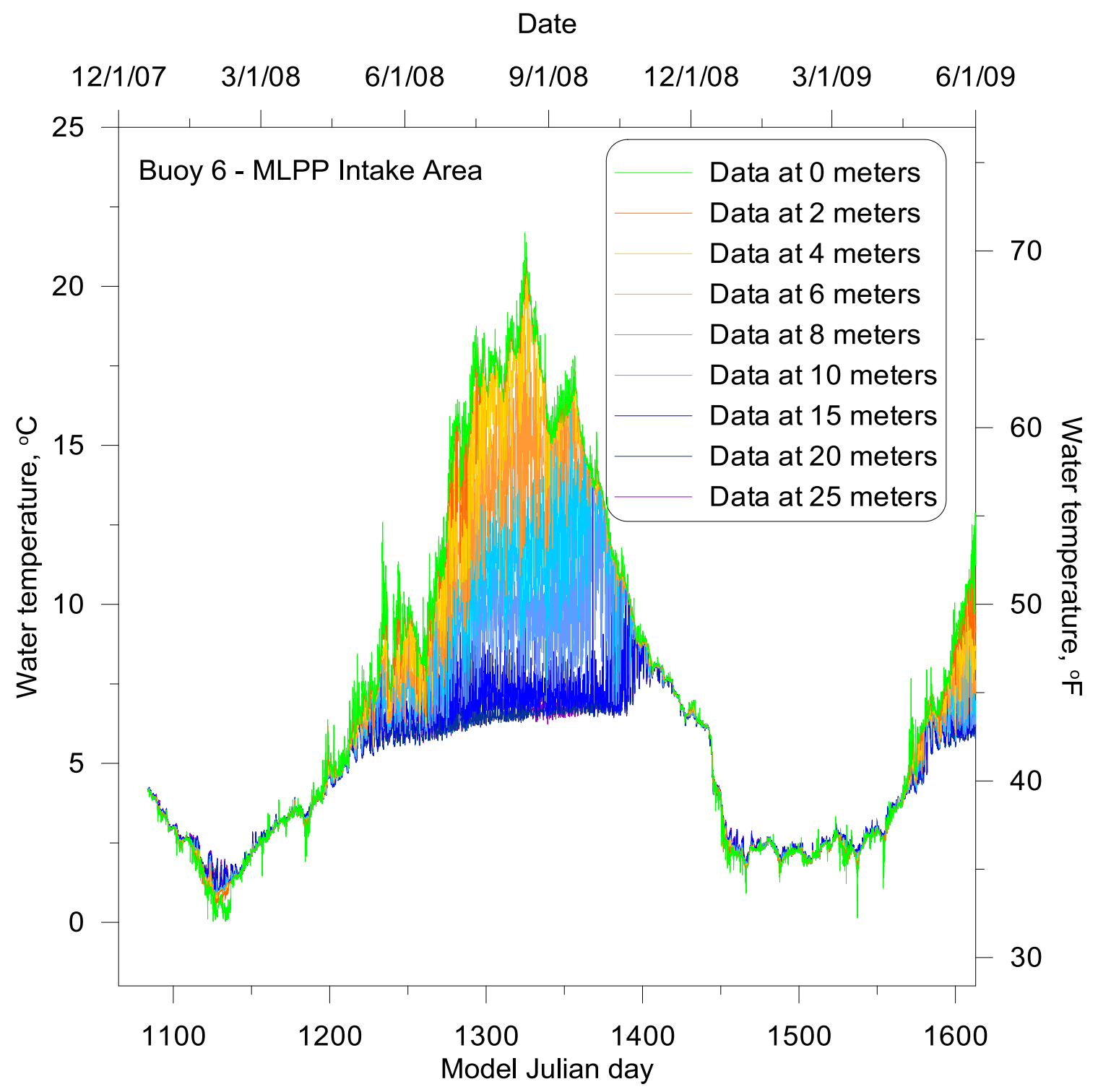

Figure 48. Time series temperature data collected at Buoy 6 (corresponding to model segment 34) 


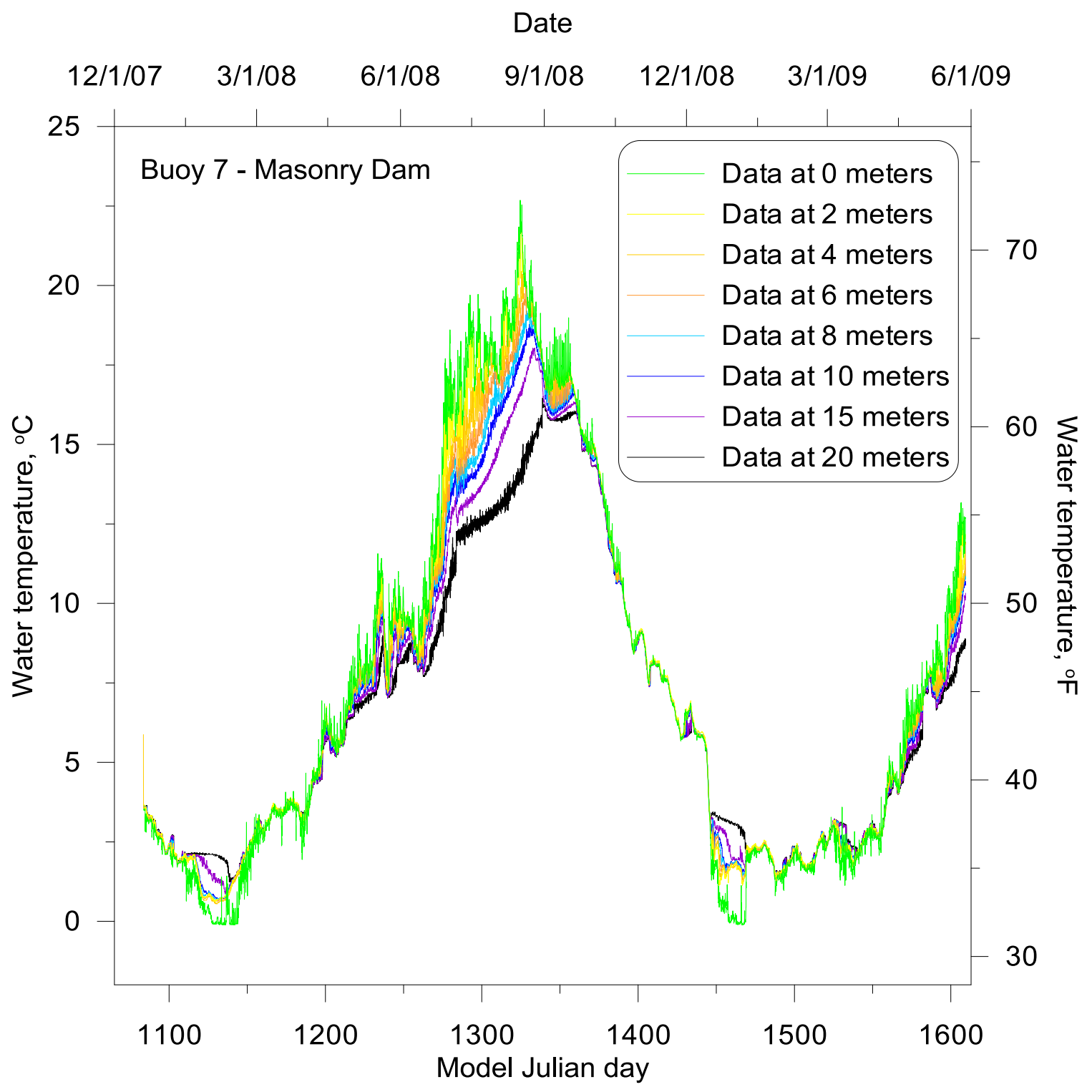

Figure 49. Time series temperature data collected at Buoy 7 (corresponding to model segment 64) Masonry Pool 


\section{Temperature Profiles}

Detailed temperature profile data was also collected at two sites during the 2005-2008 modeling period. The first sample location corresponds to segment 28 in the center of Chester Morse Lake. The temperature profiles for this location are displayed in Figure 50, Figure 51, Figure 52, and Figure 53 for sample years 2005, 2006, 2007, and 2008.

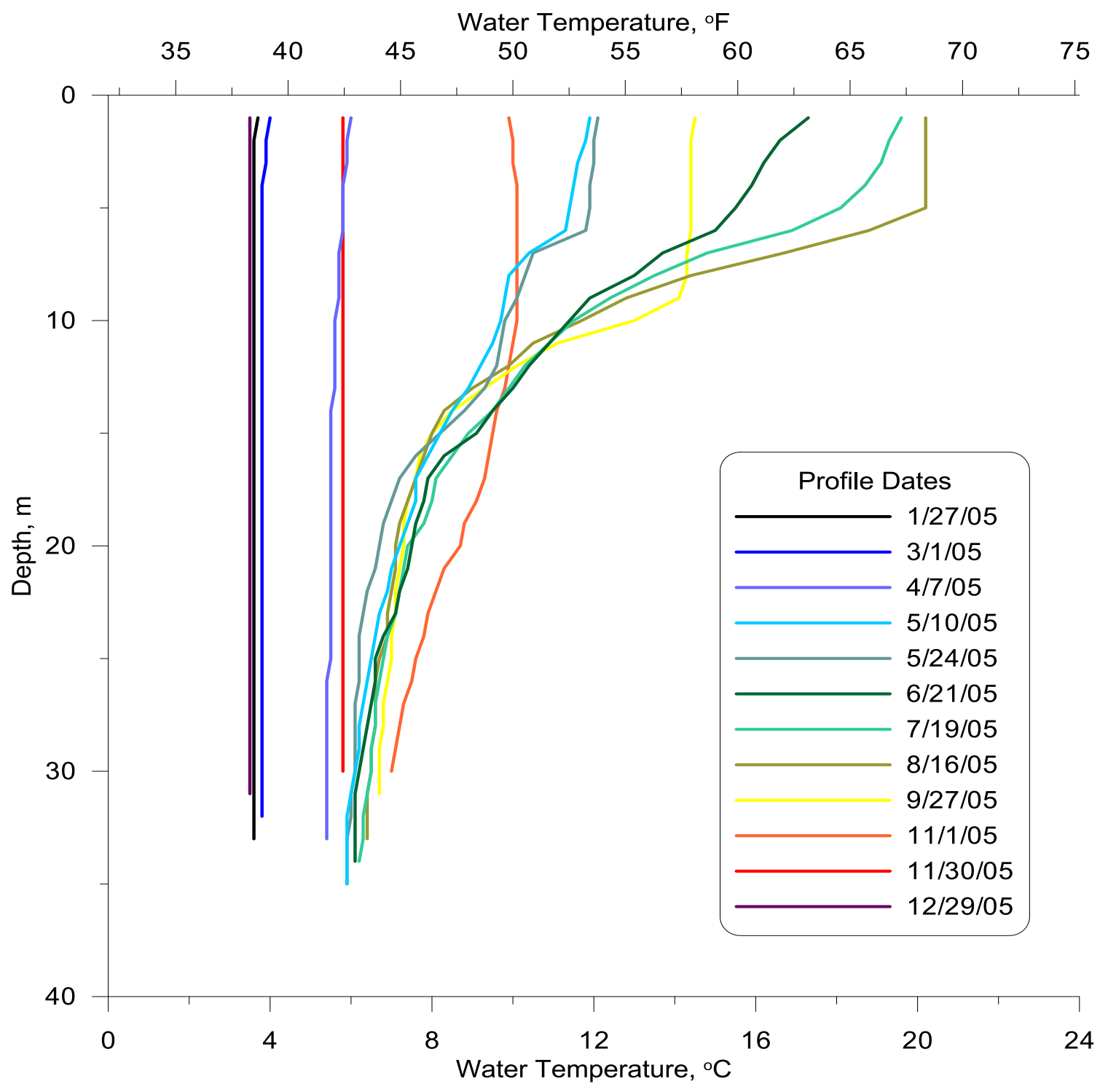

Figure 50. Temperature profiles collected at center of Chester Morse Lake, 2005 


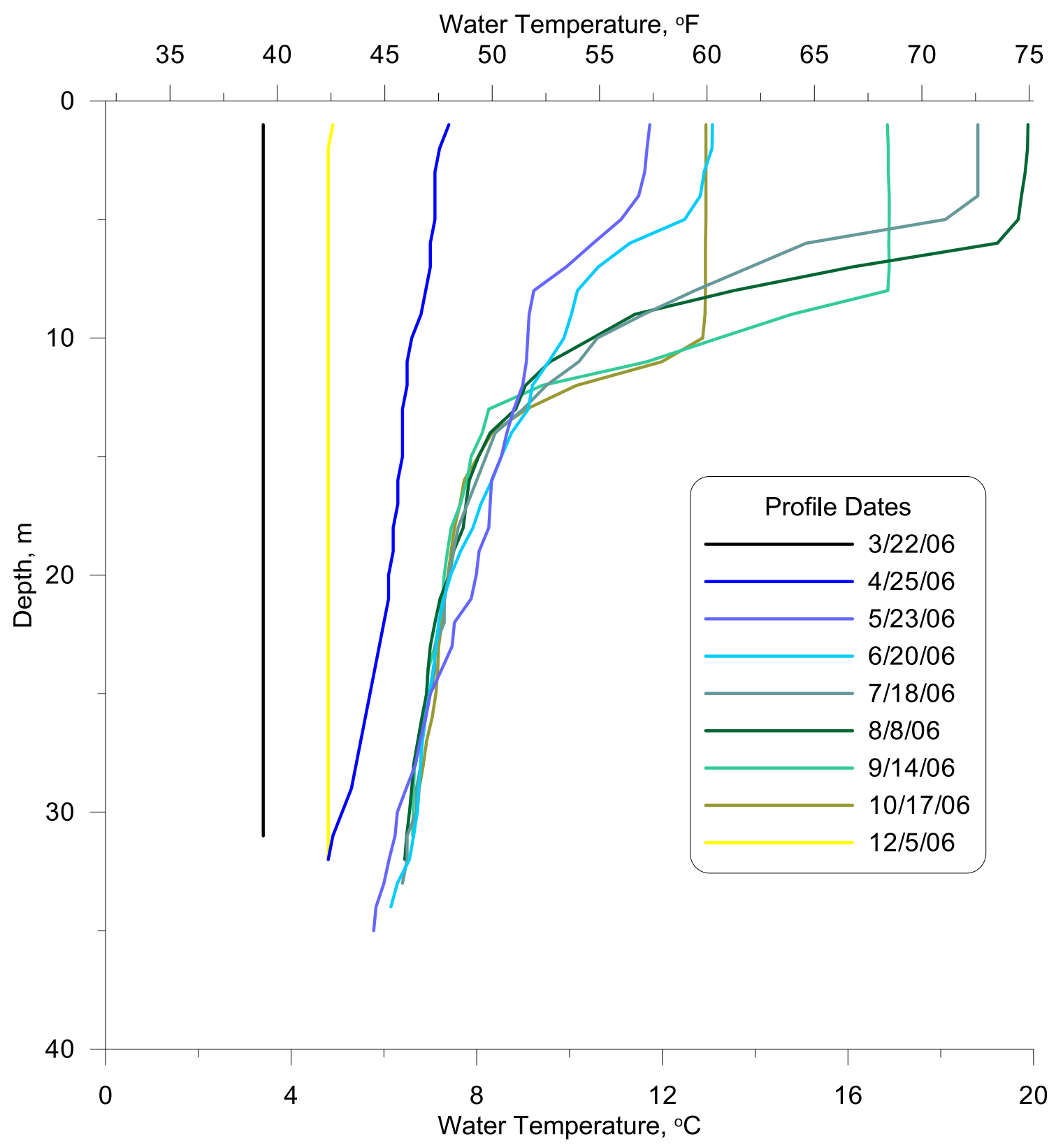

Figure 51. Temperature profiles collected at center of Chester Morse Lake, 2006 


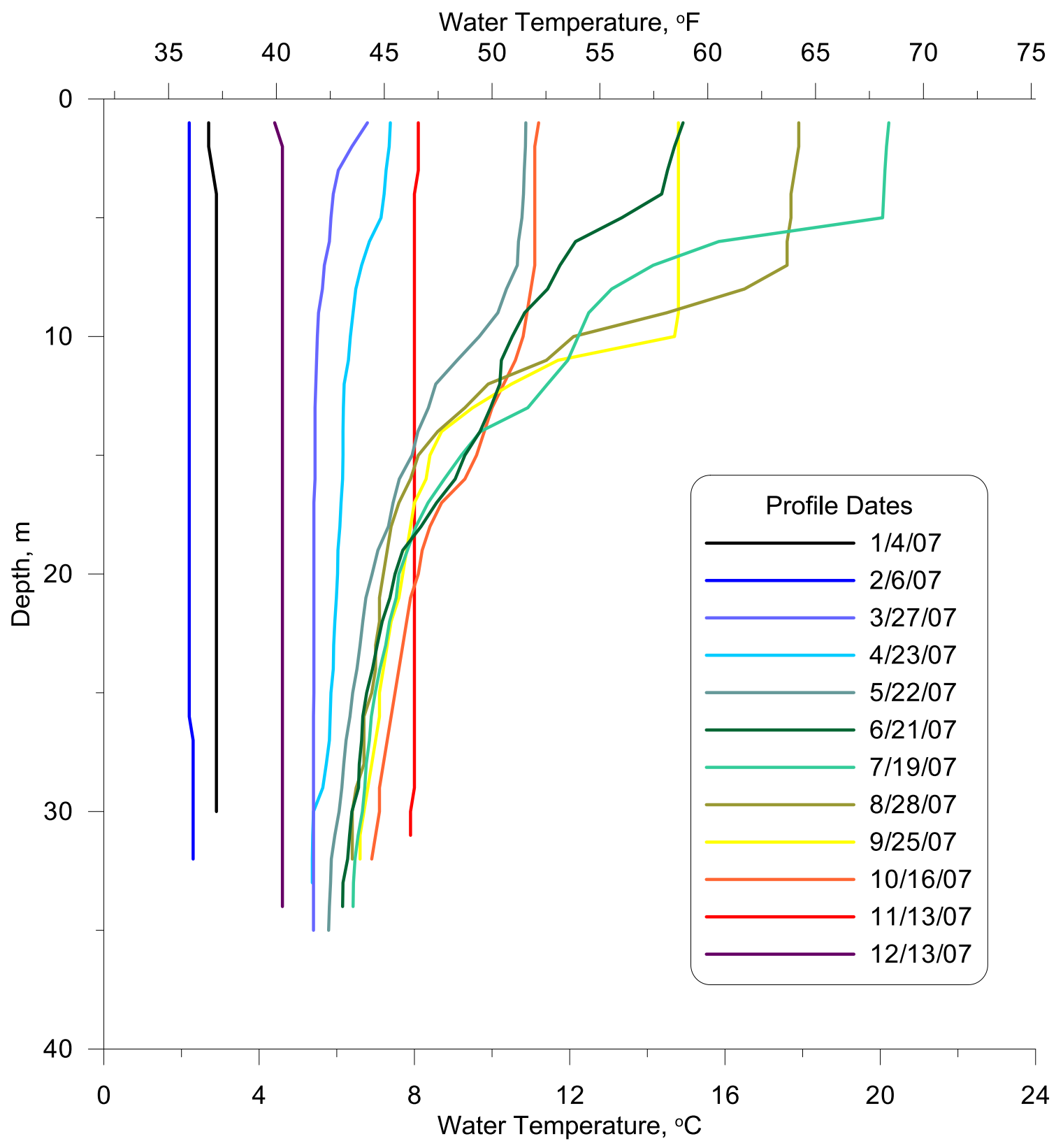

Figure 52. Temperature profiles collected at center of Chester Morse Lake, 2007 


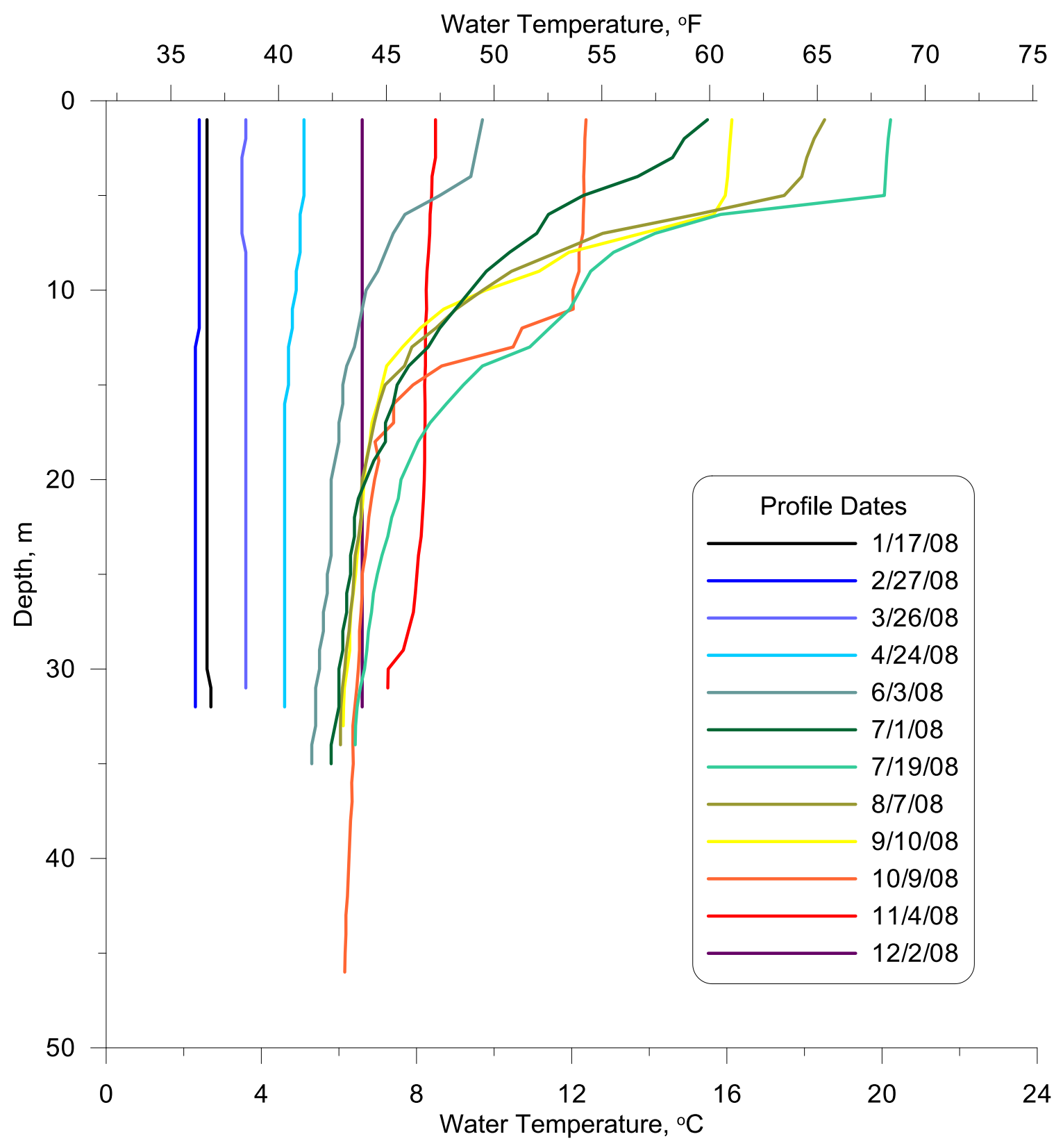

Figure 53. Temperature profiles collected at center of Chester Morse Lake, 2008 
The second sample location corresponds to model segment 64, at the Masonry Dam.

Figure 54 displays the 5 temperature profiles taken at that site for the period between 2005 and 2008.

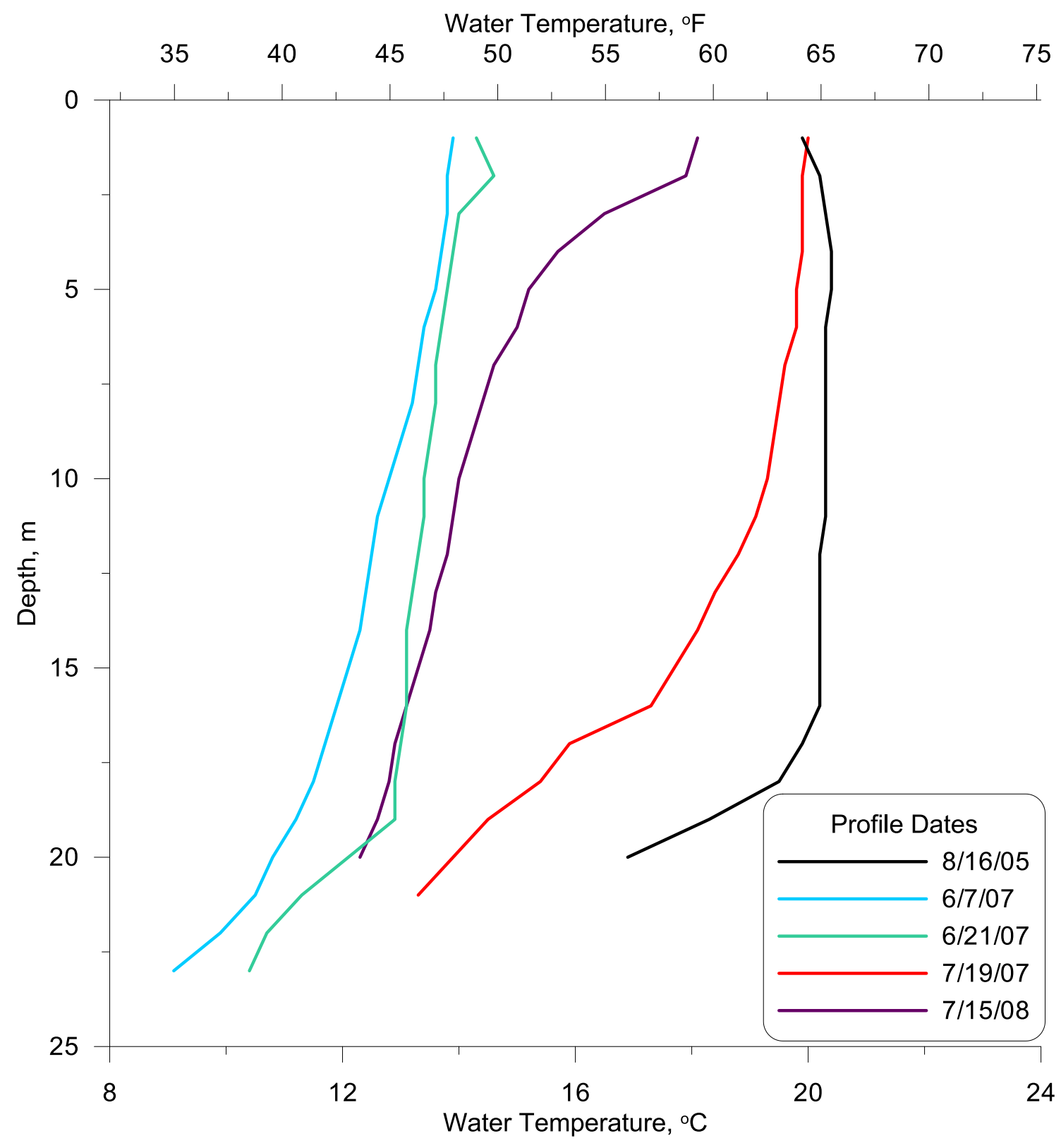

Figure 54. Temperature profiles collected in Masonry Pool near Masonry Dam, 2005-08 


\section{Cedar River Temperature Data}

River temperature data downstream of Chester Morse Lake was available at two USGS locations on the Cedar River: USGS 12116500 downstream of Cedar Falls and USGS 12117600 at Landsburg after the drinking water diversion. The river model extends to just upstream of the diversion, so the last model segment is used for comparison to this data. Data from these two sites for the duration of the calibration period is shown in Figure 55.

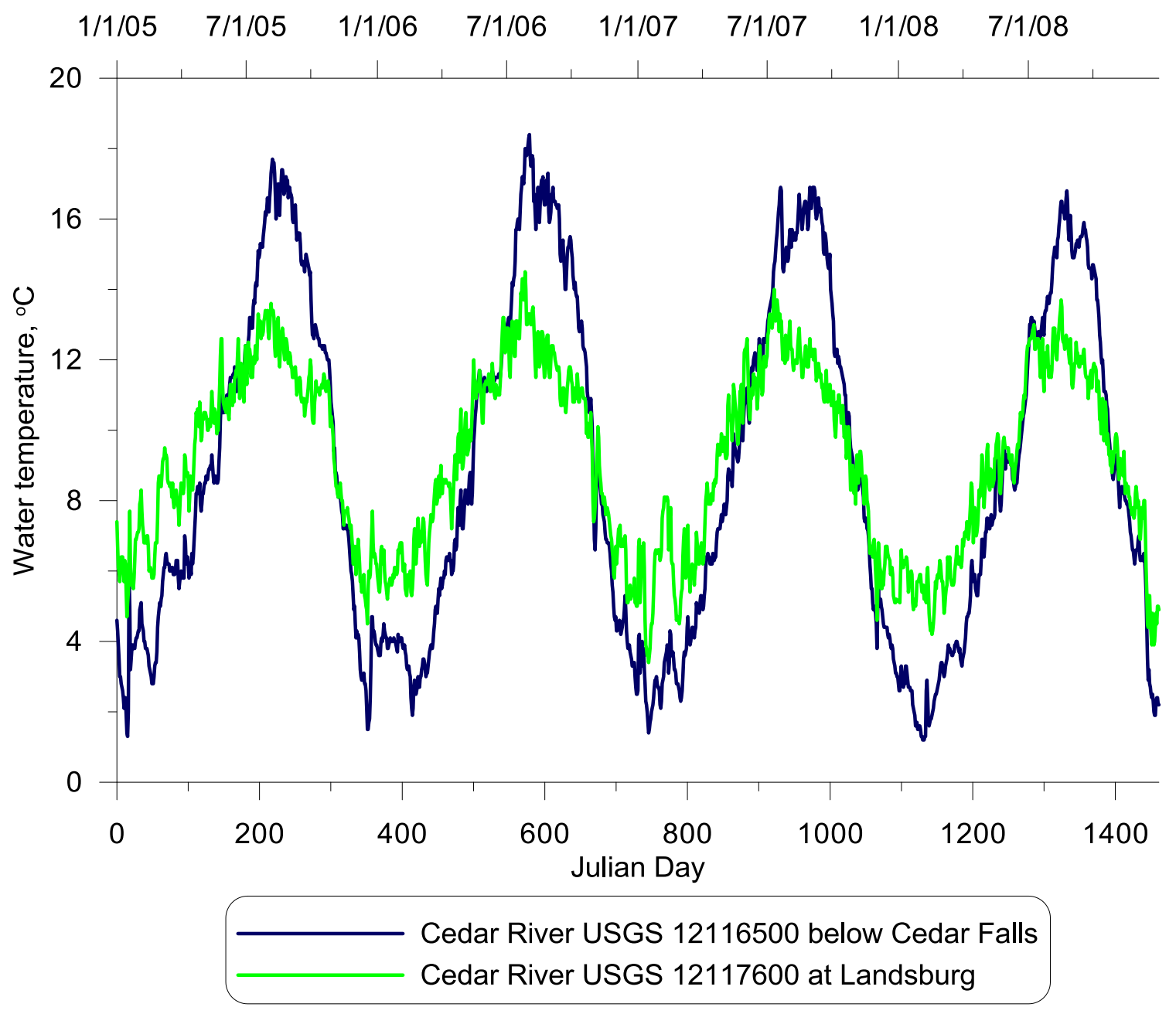

Figure 55. Cedar River USGS temperature data 


\section{Flow Calibration}

\section{Chester Morse Lake Flow Calibration}

The initial model calibration step was to match measured water level elevations over the full period of the model run. The initially quantified inflow and outflows do not account for seepage through the moraine (from the Masonry Pool) or direct precipitation onto the lake surface, and likely contain some inaccuracies due to errors in flow estimation for ungauged stream inflows as well as possible errors in gaged stream flow. In order to account for these, a water balance was carried out on the system to determine how much water needed to be either added or subtracted to match observed water elevations. This process, generally fairly simple and straightforward, was a long and labor intensive process for this system. The intermediate overflow dam, pipe systems, and high seepage rates considerably complicated the water balance process. All flows were added or subtracted from the Masonry Pool as a distributed flow based upon the assumption that water loss through the moraine was the most significant ungauged outflow from the system. The final flow calibration results are shown in Figure 56. The model water elevations in the Masonry Pool (red) and main lake (green) are plotted over observed water elevations. 


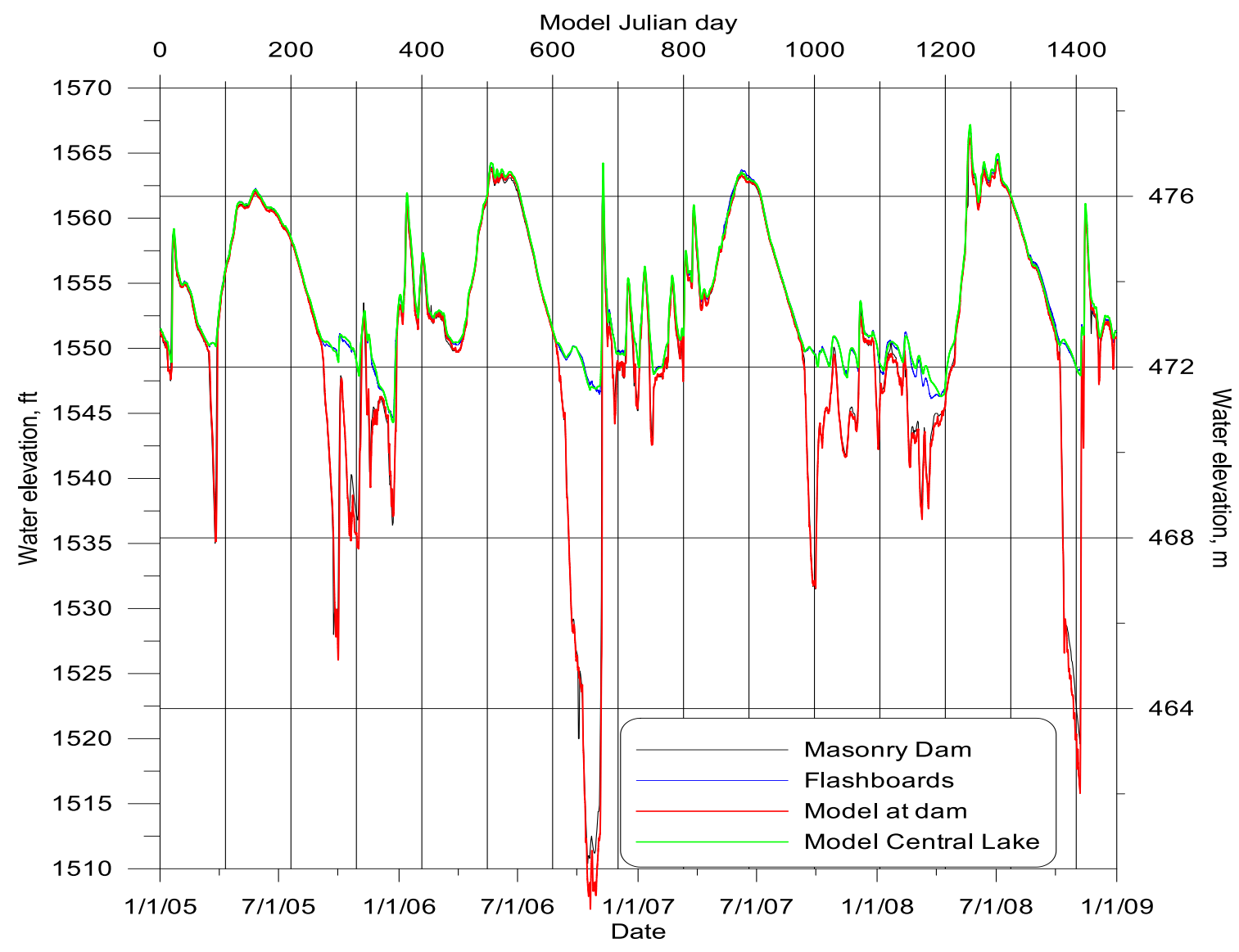

Figure 56. Water levels after flow calibration

The water balance flow rates at varying water surface elevations in the Masonry Pool are shown in Figure 57. These are compared to Equation 4 used by Water Management to estimate average daily seepage loss from the Masonry Pool. The water balance flow includes both seepage loss and the other uncertainties in flow mentioned earlier, so a direct comparison cannot be made. However, it is clear that both the seepage equation and the water balance flow generated by the model are generally of similar magnitudes.

Equation 4. Water Management Seepage equation (Paige, 2009)

Seepage Loss $(c f s)=\left((\text { Masonry Pool Elev }(f t)-1500)^{2.3035} * 0.023039\right)+35.47$ 


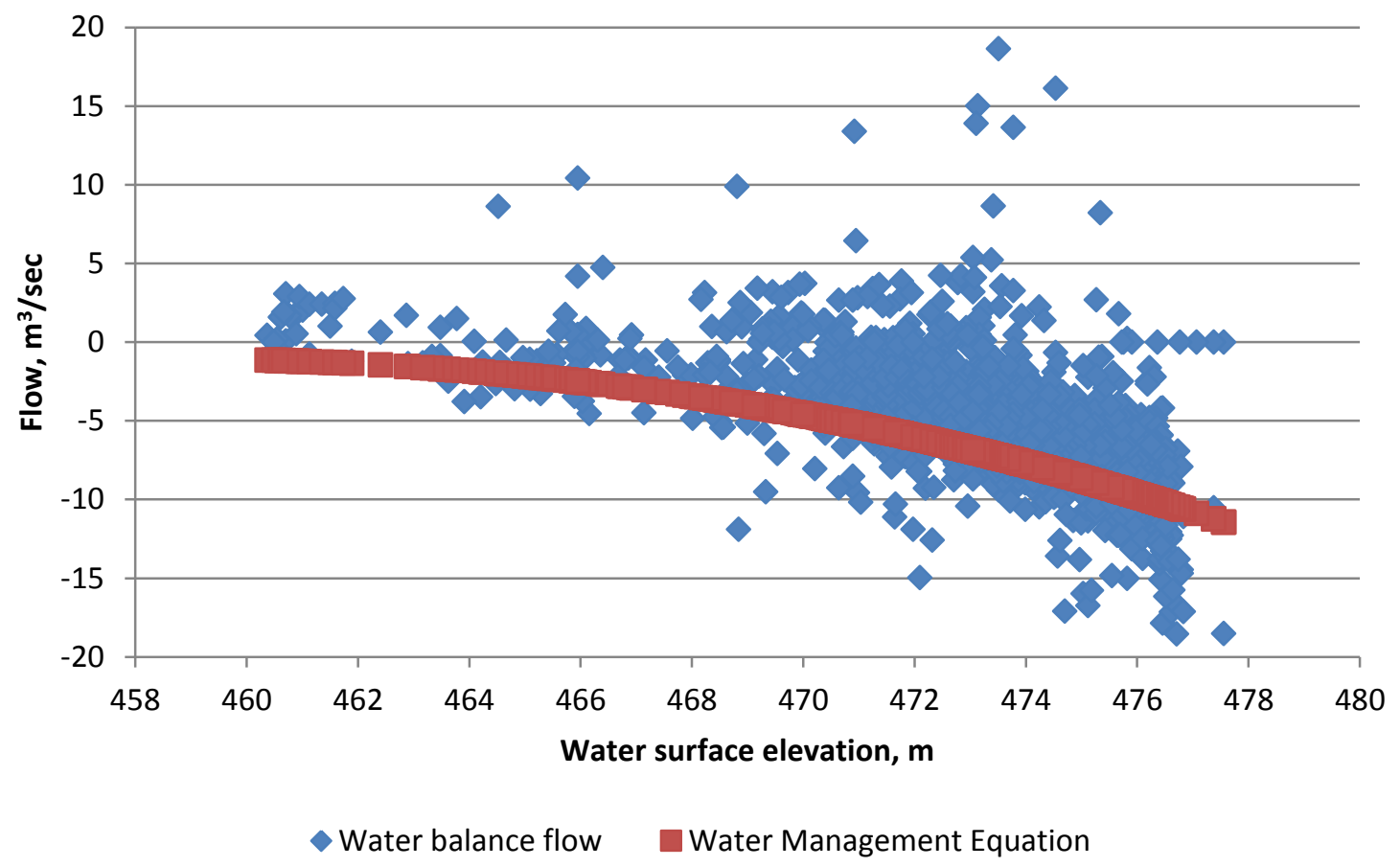

Figure 57. Comparison of water balance flows to seepage loss equation

\section{Cedar River Flow Calibration}

The Cedar River flow calibration was done by means of a simple mass balance approach. Known inflows were compared to the known flow in the river at Landsburg - at the end of the model grid. The difference in volume between the inflows and the actual downstream river flow was then calculated and the total was divided up between the various ungauged drainage basins that feed into the Cedar River, based upon drainage area (using the same method as illustrated in Equation 2.) Three of these drainage basins entered the model as tributaries, and two were modeled as distributed tributaries. Table 12 shows the each tributary or inflow name, the segment at which it entered the model and the percent of watershed drained by each sub basin. 
Table 12. Cedar River tributary summary

\begin{tabular}{|c|c|c|c|c|}
\hline $\begin{array}{c}\text { Tributary/Basin } \\
\text { Name }\end{array}$ & $\begin{array}{c}\text { Model } \\
\text { Designation }\end{array}$ & $\begin{array}{c}\text { Segment at } \\
\text { which enters } \\
\text { model }\end{array}$ & $\begin{array}{c}\text { Basin Area, } \\
\text { as \% of } \\
\text { total }\end{array}$ & $\begin{array}{c}\text { Measured } \\
\text { or } \\
\text { estimated? }\end{array}$ \\
\hline Canyon Creek & Tributary 2 & 9 & - & measured \\
\hline Taylor Creek & Tributary 6 & 45 & - & measured \\
\hline Steele Creek & Tributary 4 & 31 & 3.9 & estimated \\
\hline Williams Creek & Tributary 5 & 44 & 9.3 & estimated \\
\hline Rock Creek & Tributary 7 & 83 & 19.3 & estimated \\
\hline $\begin{array}{c}\text { Cedar River } \\
\text { Basin below } \\
\text { falls }\end{array}$ & $\begin{array}{c}\text { Distributed } \\
\text { Tributary branch } \\
4\end{array}$ & $19-65$ & 38.5 & estimated \\
\hline $\begin{array}{c}\text { Cedar River } \\
\text { Basin below } \\
\text { Taylor Creek }\end{array}$ & $\begin{array}{c}\text { Distributed } \\
\text { Tributary branch } \\
5\end{array}$ & $68-95$ & 28.9 & estimated \\
\hline
\end{tabular}

The final flow calibration results are shown in Figure 58.

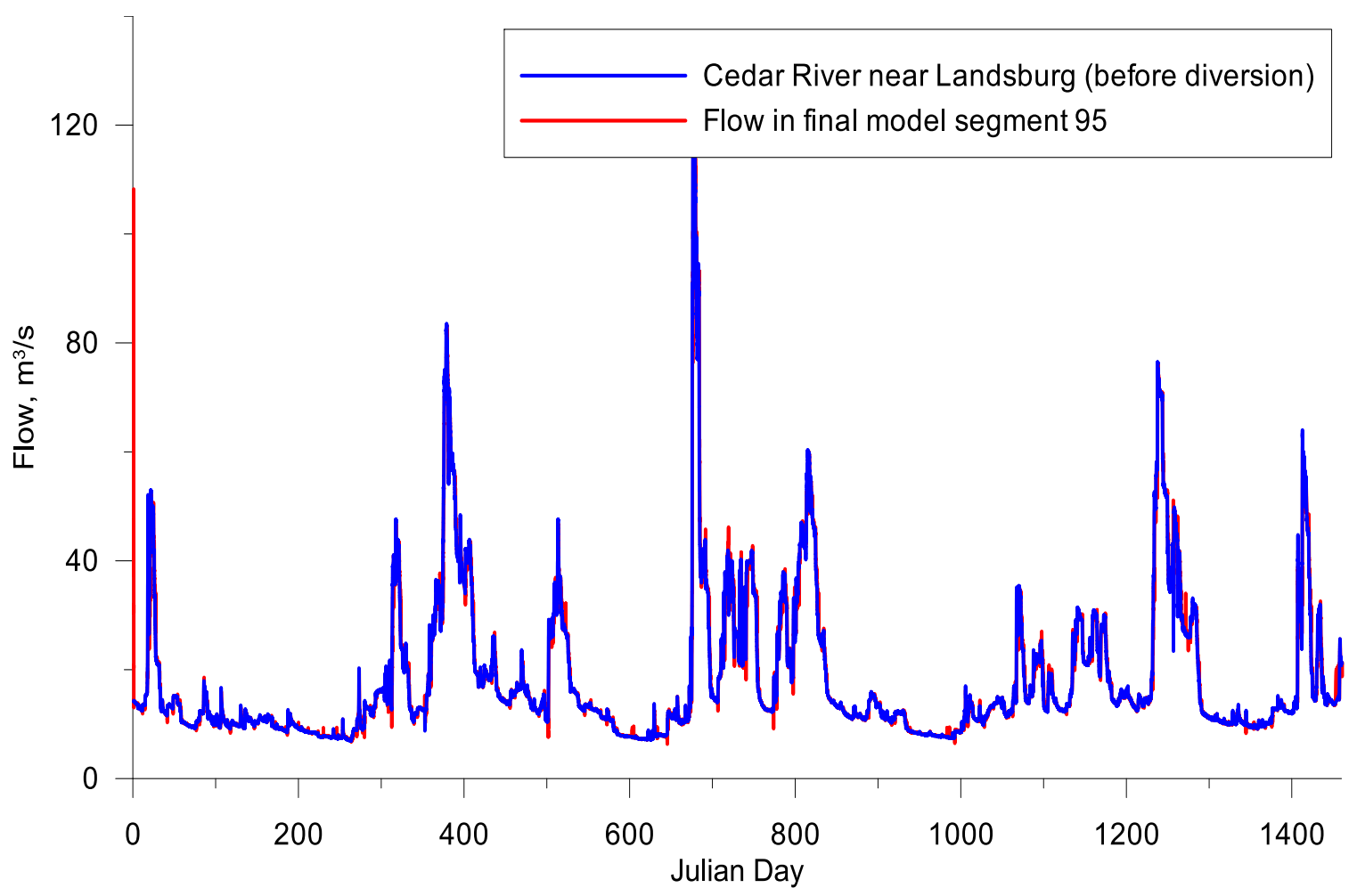

Figure 58. Cedar River flow calibration results 


\section{Temperature Calibration and Final Temperature Results}

\section{Chester Morse Lake Temperature Calibration}

The temperature calibration for Chester Morse Lake focused on matching two sets of available temperature data:

1. Time-series data collected at 7 locations throughout the lake

2. Static profiles collected at two locations, one in the main lake, and the other in the Masonry Pool

Calibration parameters for the Chester Morse Lake model included:

1. Wind sheltering coefficient (WSC) - a factor that is multiplied by wind speed to either increase or decrease wind velocity by segment and date

2. Light extinction coefficient (EXH2O)

3. B coefficient in wind-speed formulation for heat exchange (BFW)

\begin{tabular}{|c|c|}
\hline Coefficient Name & Final Calibration Coefficient Values \\
\hline $\begin{array}{c}\text { Wind sheltering coefficient } \\
\text { (WSC) }\end{array}$ & $0.2-1.3$ (varies spatially and temporally) \\
\hline $\begin{array}{c}\text { Light extinction coefficient } \\
\text { (EXH20) }\end{array}$ & 0.45 (ML) 0.60 (MP) \\
\hline $\begin{array}{c}\text { B heat exchange coefficient } \\
\text { (BFW) }\end{array}$ & $0.10(\mathrm{ML}) 0.46$ (MP) \\
\hline
\end{tabular}

Note: ML (Main Lake); MP (Masonry Pool)

The WSC was adjusted based upon observed mixing patters but remained between 0.7

and 1.3 for the majority of the model run. Figure 59 plots the WSC as a function of time for segments 2 and 20. Model segments 2-10 have identical WSC values and model 
segments 11-65 have identical WSC values.

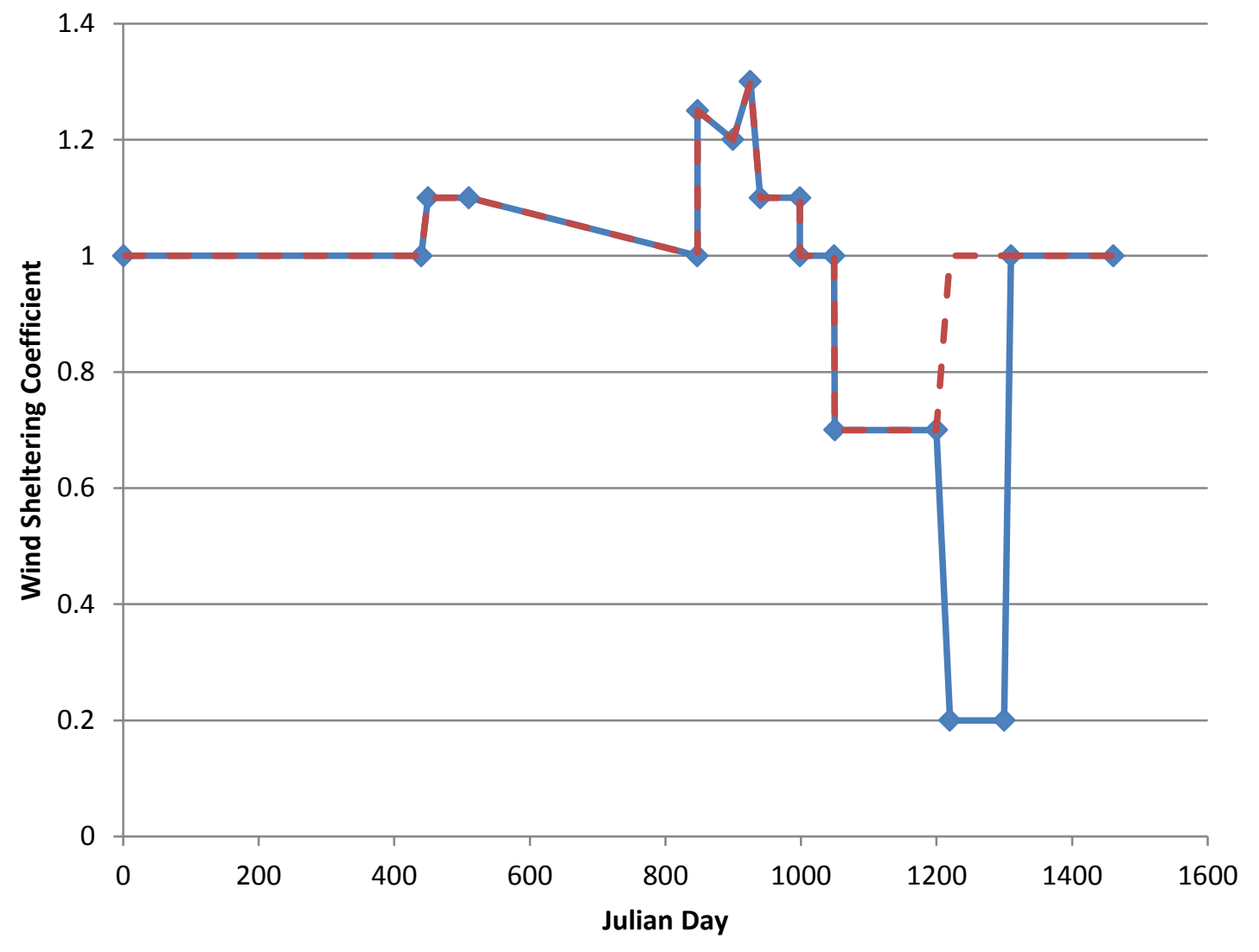

$\longrightarrow$ Segment $2-$ Segment 20

Figure 59. Wind sheltering coefficient for model segments 2 and 20

For a brief period in 2008 the WSC was reduced to 0.2 in the first 9 segments to account for unusual heating between the Cedar River inflow to Chester Morse Lake (USGS gage 12115000) and buoy 1. Cedar River inflow temperatures at this time were recorded at approximately $8^{\circ} \mathrm{C}$. At the same time surface temperatures at buoy 1 (only $2 \mathrm{~km}$ downstream) were registering $20^{\circ} \mathrm{C}$. Such extreme heating in section appeared to be unprecedented. After discussion with SPU, the conclusion was reached that this issue is 
likely due to an error in the USGS boundary condition temperature data. Figure 60 and Figure 61 show the period in question. The colored lines/symbols show measured data, the black line shows model results.

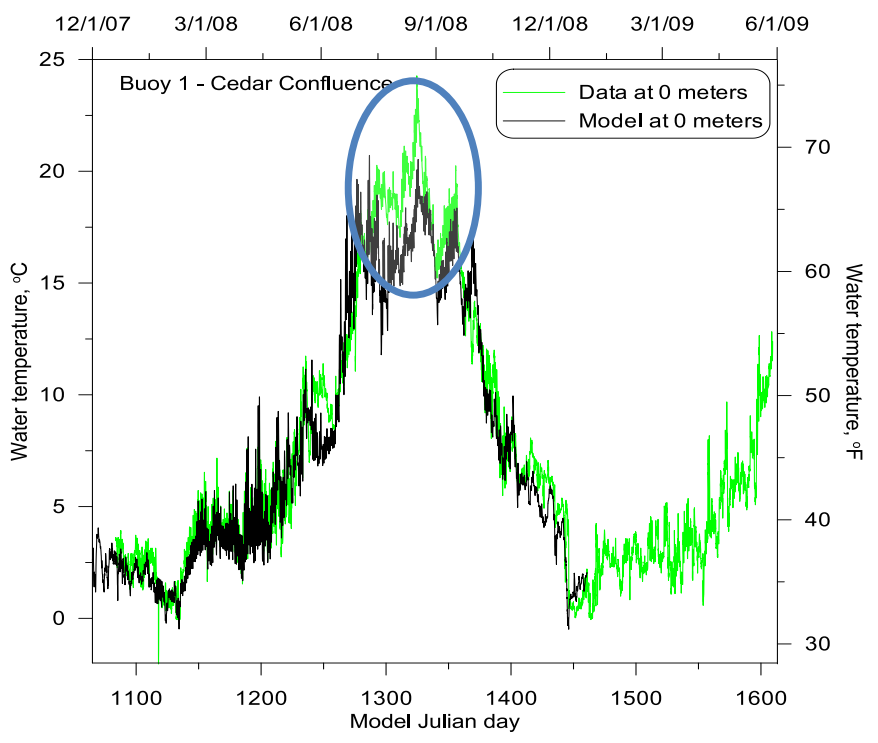

Figure 60. Cedar River confluence - highlighting Cedar River inflow temperature issue
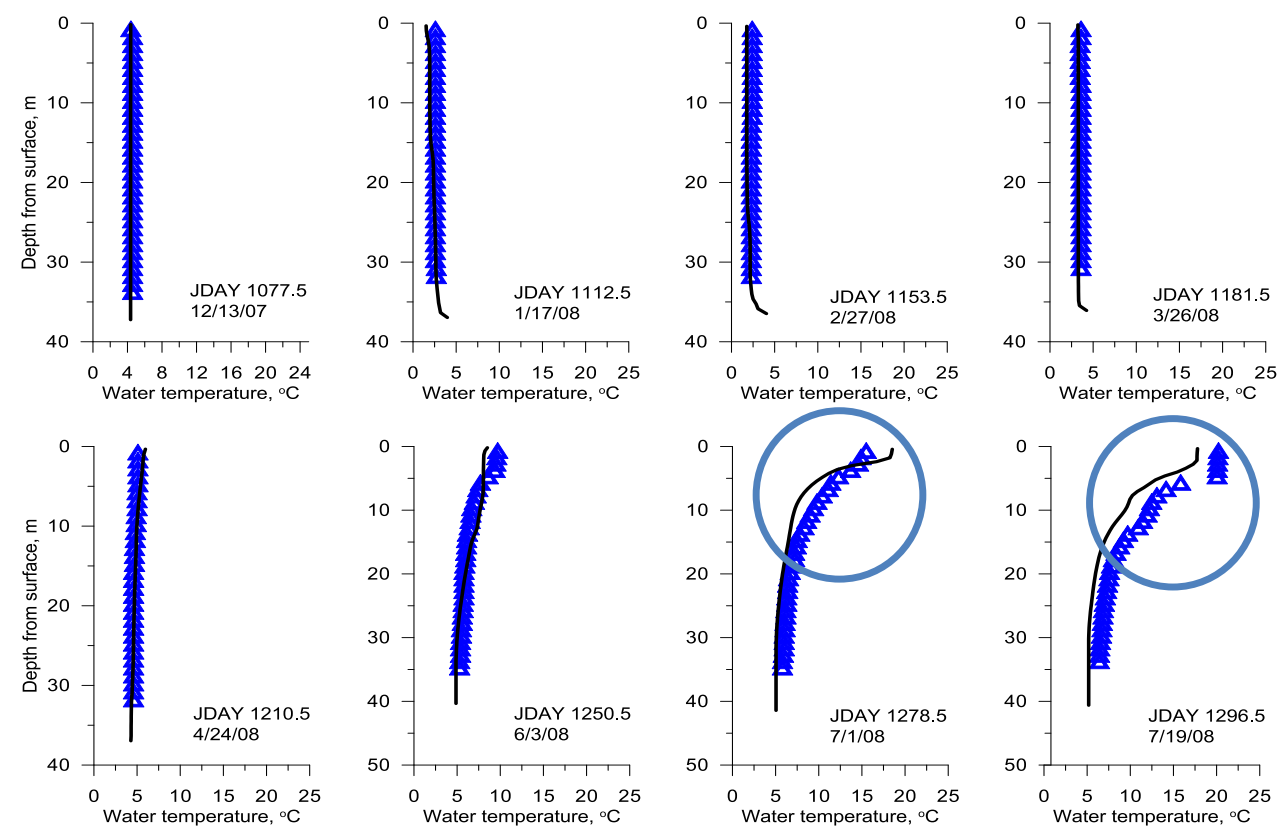

Figure 61. Mid-lake temperature profiles - highlighting Cedar River mid-summer 2008 inflow temperature issue 
The light extinction coefficient was increased in the Masonry pool in contrast to the main lake to account for cool water storage at depth. The origin of this problem is likely an unaccounted-for inflow of cold water into the Masonry pool during the spring snow melt. To illustrate this concept, a cold water inflow (estimated at $20 \%$ of the distributed inflow to the main lake) was added to the Masonry pool for 2008. Figure 62 and Figure 63 show the model vs. data comparison with and without the cold spring inflow. It is likely that similar inflow occurred in all years (although of lesser volume, since 2008 had an unusually fast and large snow melt); however there is no further data available for comparison.

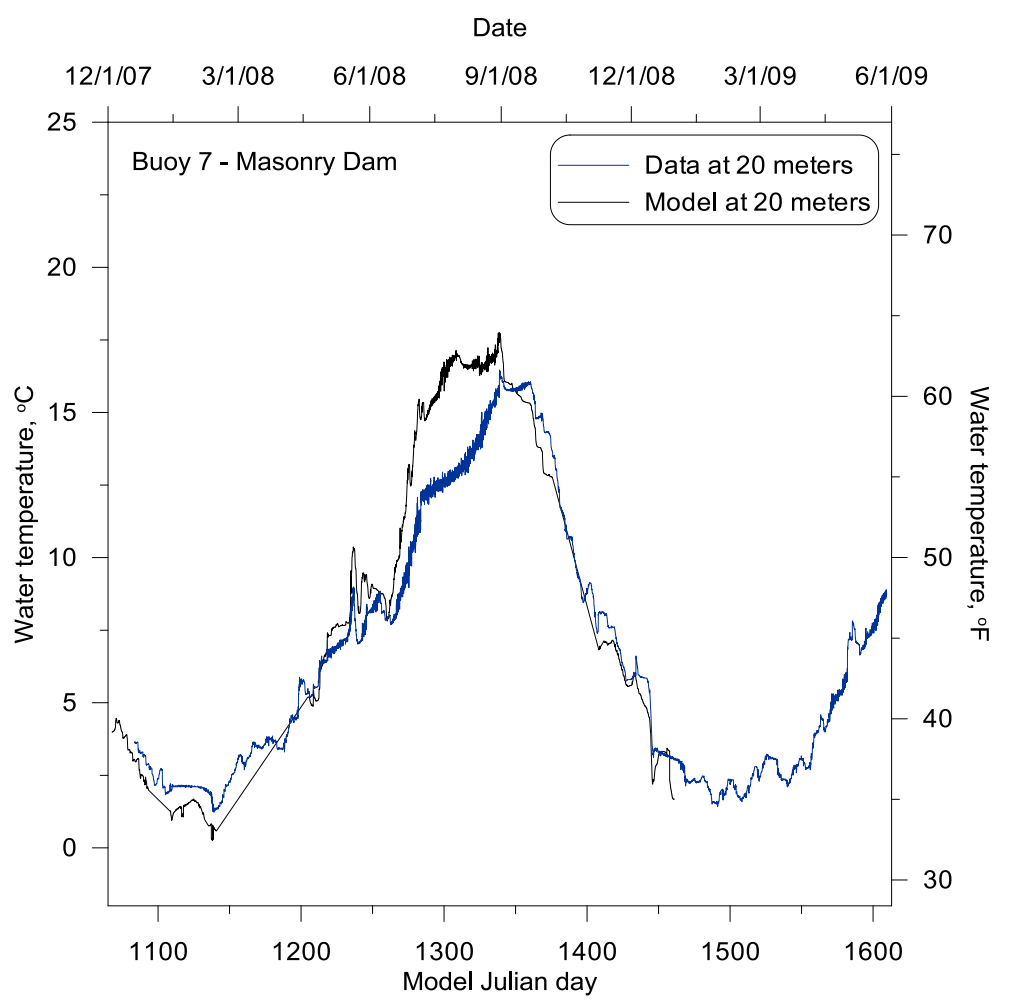

Figure 62. Model data comparison at buoy 7, depth 20 meters - no cold water spring inflow 


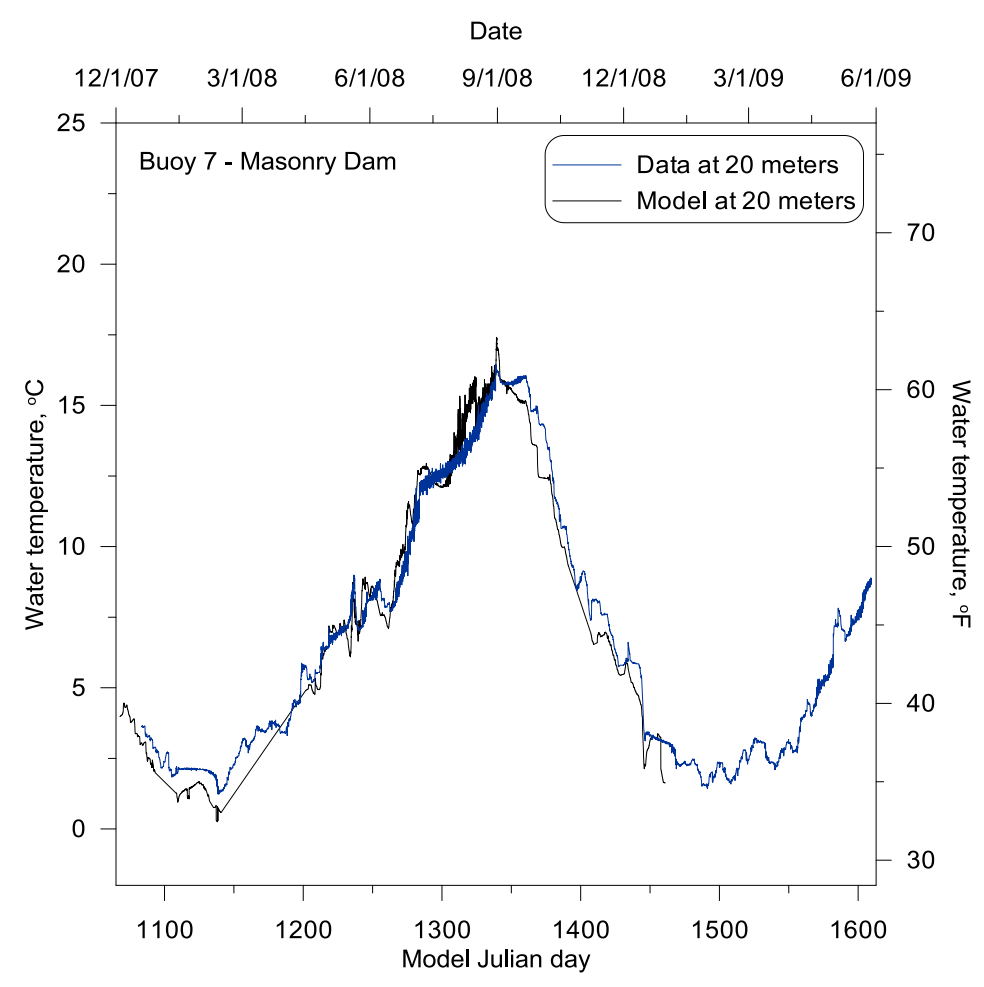

Figure 63. Model data comparison at buoy 7, depth 20 meters - cold water spring inflow

As a further test, a continual small inflow of cool water was added to determine the model's sensitivity, and it showed that the timing and volume of the inflow was critical. Constant cool water inflow to the Masonry pool adversely impacted the temperature profiles, cooling the whole temperature profile. The best solution would likely be to estimate spring drainage for each individual year based upon available flow records. Unfortunately continuous temperature data is not available for comparison for years other than 2008. This solution might then allow for the light extinction coefficient (EXH2O) to be uniform over the whole system. Currently for best temperature results the EXH2O is 0.6 in the Masonry Pool and 0.45 in the main lake. The higher coefficient causes more heat to be trapped in the upper layers, causing less heating to the cool 
water pool below. With additional spring cool water inflow, this coefficient adjustment might be unnecessary.

BFW was also adjusted to 0.1 (main lake) and 0.46 (Masonry Pool) to better match heatexchange patterns in the lake. Again, which more accurate spring runoff flows into the Masonry Pool, this non-uniform approach might be unnecessary. The result of tuning these parameters to match temperature data is illustrated in the following examples. 
Figure 64 and Figure 65 show pre- calibration (default model parameter values) and post-calibration (model parameter values changed to better match temperature data) model data comparisons at segment 64 (buoy 7).

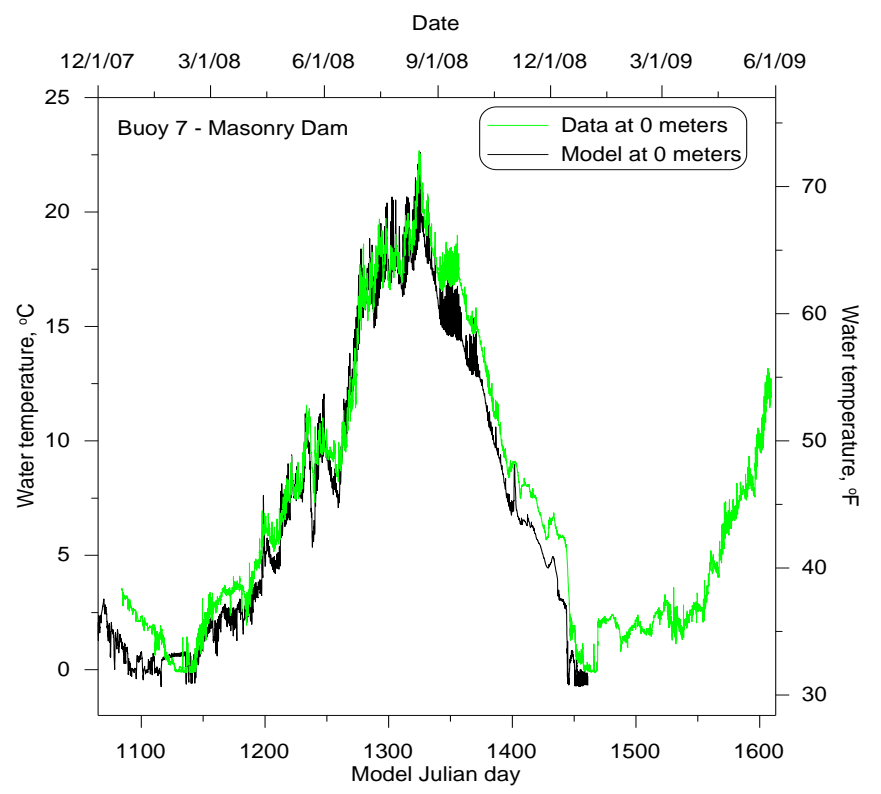

Figure 64. Model data comparison at buoy 7 - pre-calibration

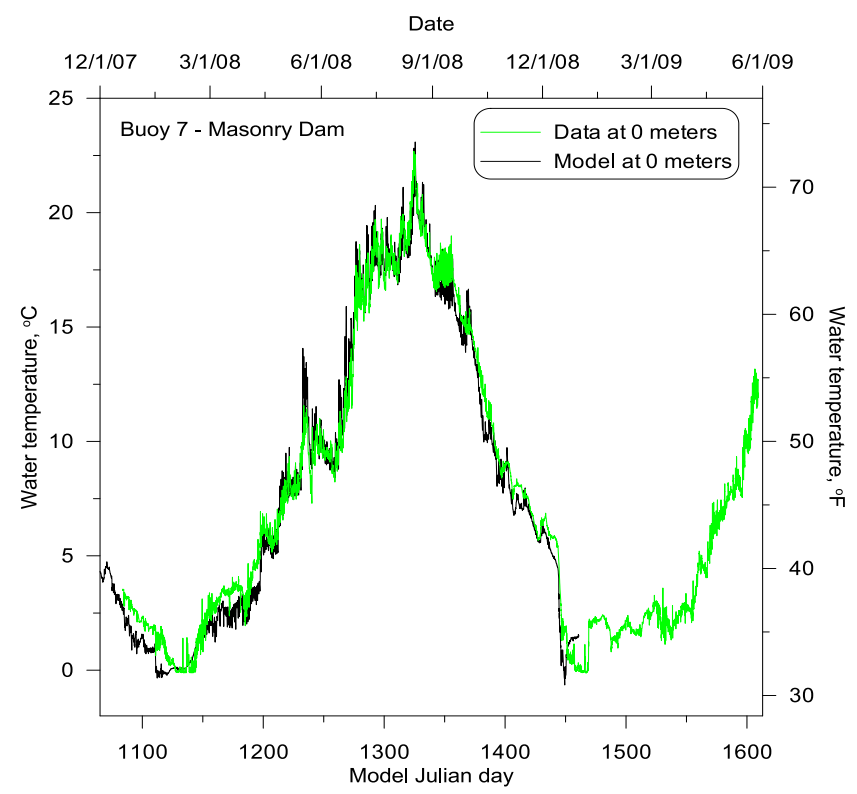

Figure 65. Model data comparison at buoy 7 - post-calibrationFigure 66 and Figure 67 show pre- and postcalibration model data comparisons at segment 47 (buoy 3). 


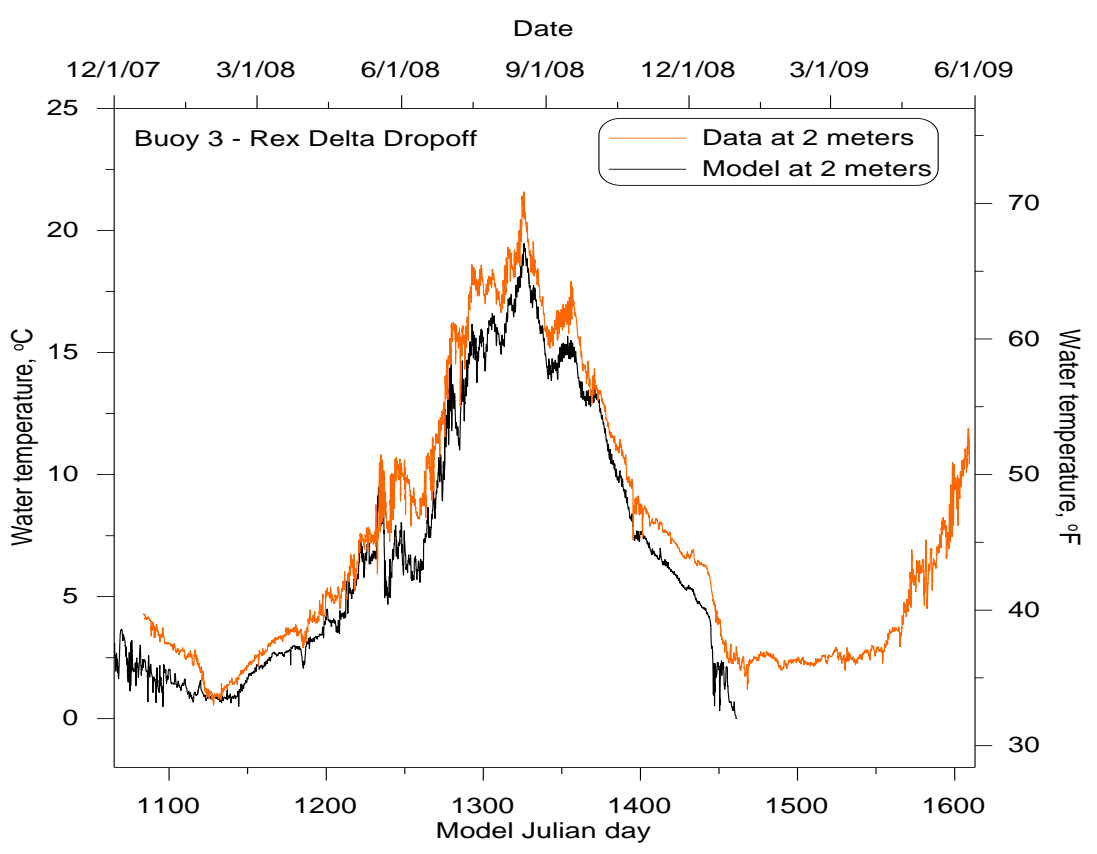

Figure 66. Model data comparison at buoy 3 - pre-calibration

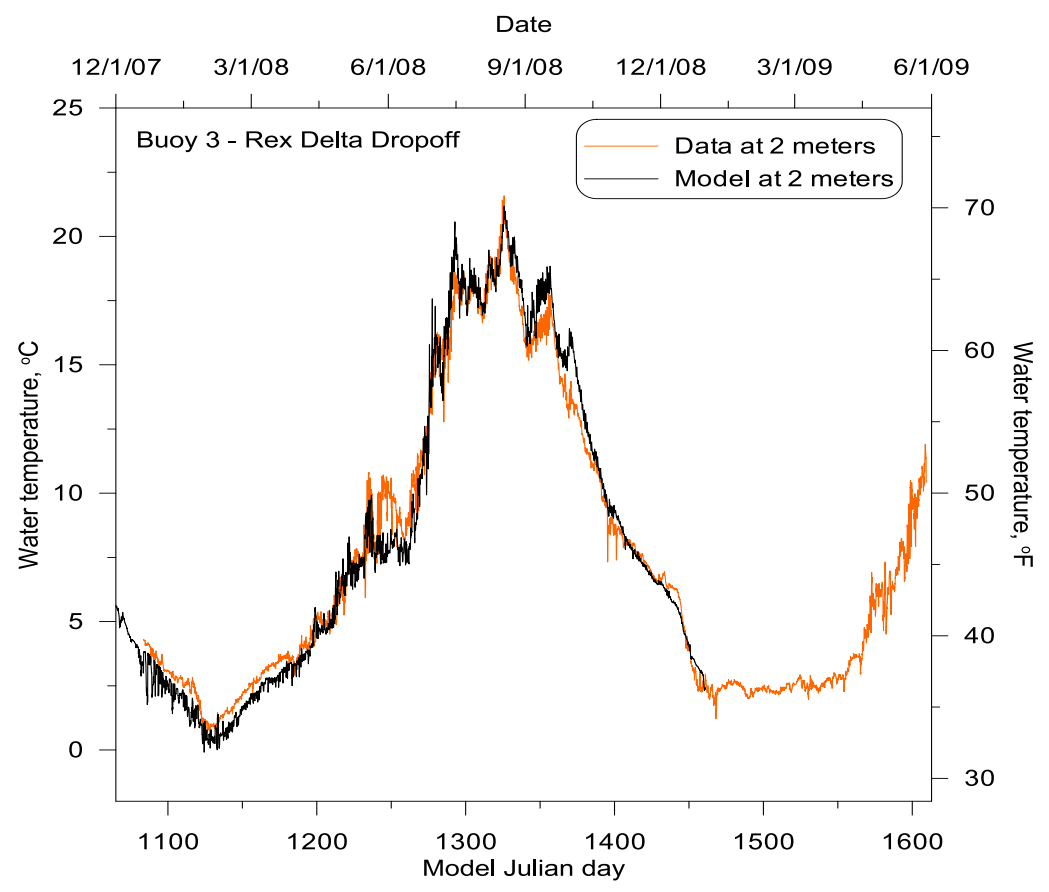

Figure 67. Model data comparison at buoy 3 - post-calibration 
Figure 68 and Figure 69 show pre- and post-calibration model data temperature profile comparisons at mid-lake (segment 27). Model is shown as a black line; data is shown as blue triangles.
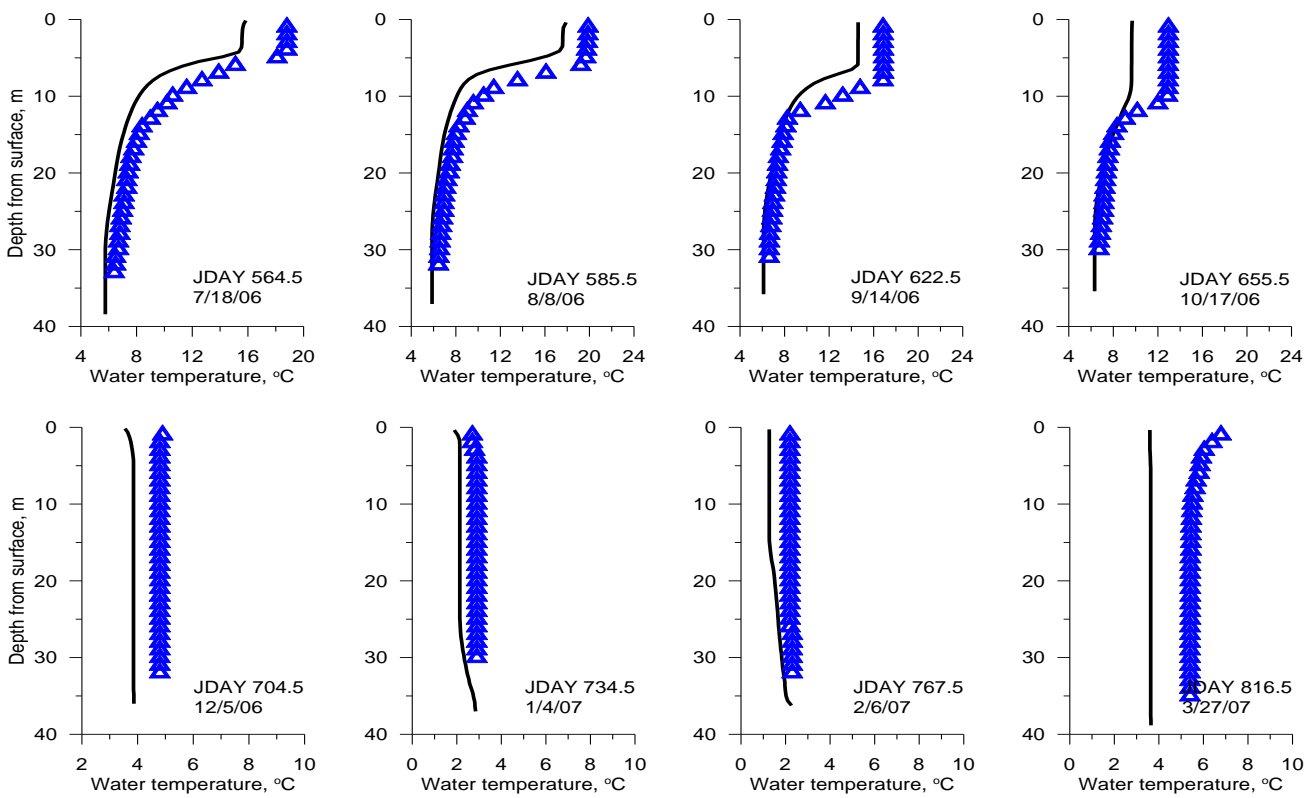

Figure 68. Model data temperature profile comparisons at mid-lake - pre-calibration
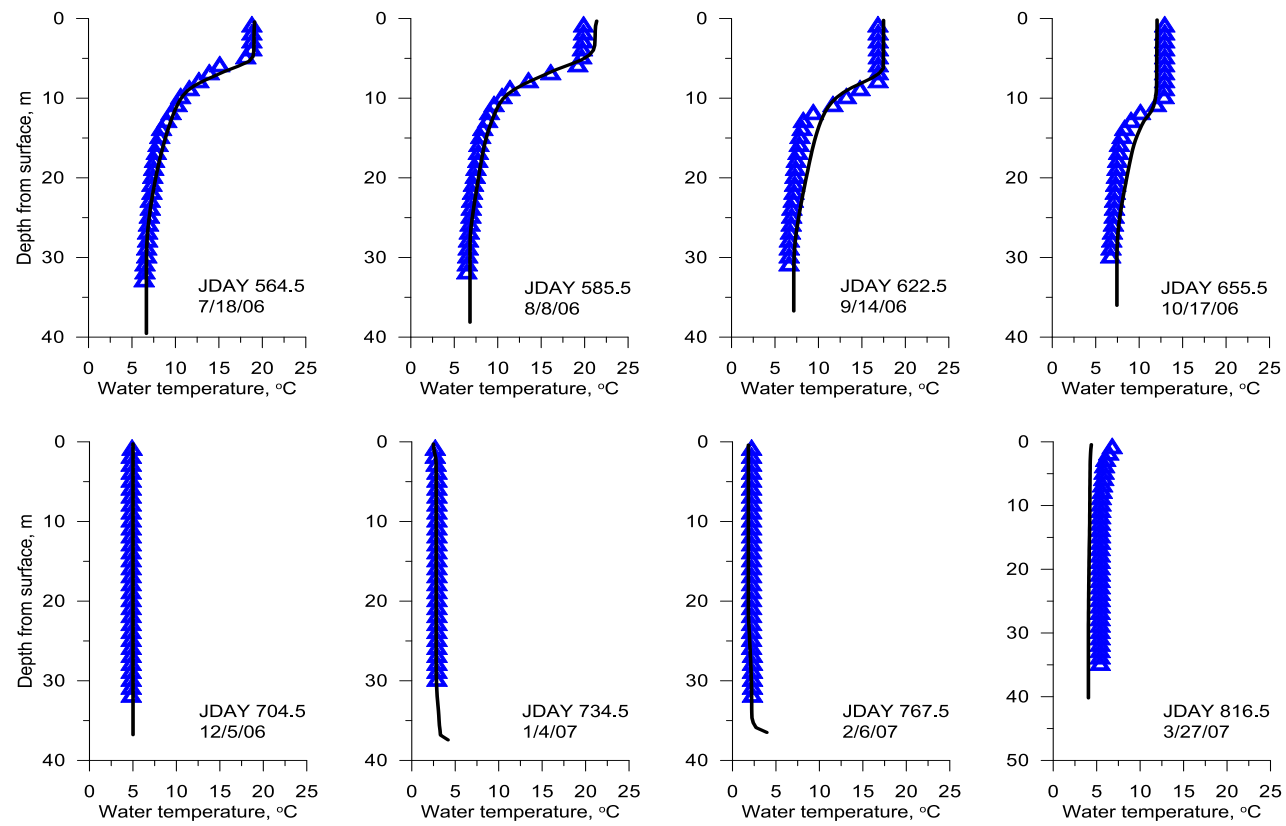

Figure 69. Model data temperature profile comparisons at mid-lake - post-calibration 


\section{Chester Morse Lake Final Temperature Results}

A summary of the final calibration temperature results is discussed in this section. For a complete graphical record of all temperature data comparisons for Chester Morse Lake please see Appendix. The post-calibration model data comparisons showed that the model was able to predict continuous water temperatures at 6 of the 7 sites to within an absolute mean error of between 0.49 and $0.92{ }^{\circ} \mathrm{C}$. The only site that did not meet this standard was at buoy 1. The likely cause of the model under predicting temperatures during this period was discussed in the previous section. A complete summary of the model vs. time-series data error statistics is shown in Table 13. The model showed no overall bias as mean errors at different stations ranged from $+0.28^{\circ} \mathrm{C}$ to $-0.36^{\circ} \mathrm{C}$.

Table 13. Chester Morse Lake model time-series temperature error statistics

\begin{tabular}{|c|c|c|c|c|c|}
\hline Buoy \# & $\begin{array}{c}\text { Segment } \\
\#\end{array}$ & $\begin{array}{c}\text { Mean } \\
\text { Error }\end{array}$ & $\begin{array}{c}\text { Absolute Mean } \\
\text { Error }\end{array}$ & $\begin{array}{c}\text { Root mean } \\
\text { squared } \\
\text { error }\end{array}$ & $\begin{array}{c}\text { Number of } \\
\text { comparisons }\end{array}$ \\
\hline 1 & 9 & -0.27 & 1.56 & 2.07 & 27,251 \\
\hline 2 & 13 & 0.28 & 0.92 & 1.38 & 99,909 \\
\hline 3 & 17 & -0.08 & 0.77 & 1.19 & 81,746 \\
\hline 4 & 23 & 0.10 & 0.49 & 0.70 & 99,902 \\
\hline 5 & 34 & 0.18 & 0.75 & 1.09 & 81,736 \\
\hline
\end{tabular}




\begin{tabular}{|c|c|c|c|c|c|}
\hline Buoy \# & $\begin{array}{c}\text { Segment } \\
\#\end{array}$ & $\begin{array}{c}\text { Mean } \\
\text { Error }\end{array}$ & $\begin{array}{c}\text { Absolute Mean } \\
\text { Error }\end{array}$ & $\begin{array}{c}\text { Root mean } \\
\text { squared } \\
\text { error }\end{array}$ & $\begin{array}{c}\text { Number of } \\
\text { comparisons }\end{array}$ \\
\hline 6 & 47 & 0.23 & 0.72 & 1.05 & 81,743 \\
\hline 7 & 64 & -0.36 & 0.71 & 0.85 & 72,647 \\
\hline All & Wt. Ave. & $\mathbf{0 . 0 5 7}$ & $\mathbf{0 . 7 7}$ & $\mathbf{1 . 0 9}$ & $\mathbf{5 4 4 , 9 3 4}$ \\
\hline
\end{tabular}

When compared to temperature profiles from two locations in Chester Morse Lake, the model also showed a high degree of accuracy. The absolute mean error of the profiles was between 0.49 and $0.83{ }^{\circ} \mathrm{C}$. The model showed almost no bias with a combined mean error of $-0.07^{\circ} \mathrm{C}$. A complete summary of the model vs. profile data error statistics is shown in Table 14.

Table 14. Chester Morse Lake model temperature profile error statistics

\begin{tabular}{|c|c|c|c|c|c|}
\hline Location & $\begin{array}{c}\text { Segment } \\
\#\end{array}$ & $\begin{array}{l}\text { Mean } \\
\text { Error }\end{array}$ & $\begin{array}{l}\text { Absolute } \\
\text { Mean } \\
\text { Error }\end{array}$ & $\begin{array}{c}\text { Root Mean } \\
\text { Squared } \\
\text { Error }\end{array}$ & $\begin{array}{l}\text { Number of } \\
\text { Comparisons }\end{array}$ \\
\hline Mid-lake & 28 & -0.11 & 0.49 & 0.72 & 1473 \\
\hline $\begin{array}{c}\text { Masonry } \\
\text { Dam }\end{array}$ & 64 & 0.44 & 0.83 & 1.11 & 107 \\
\hline Total & $28 \& 64$ & -0.07 & 0.51 & .076 & 1580 \\
\hline
\end{tabular}




\section{Cedar River Temperature Calibration}

The temperature calibration for the Cedar River model focused on matching time-series temperature data at two sites along the river. The fully calibrated Chester Morse Lake model was used to provide the upstream flow and temperature boundary conditions.

Very little was done to change the river model from its initial settings. The most important factor was correct inflow temperatures from the Chester Morse Lake model.

\section{Cedar River Final Temperature Results}

The model data comparison of the fully calibrated model at segment 16 is shown in

Figure 70.

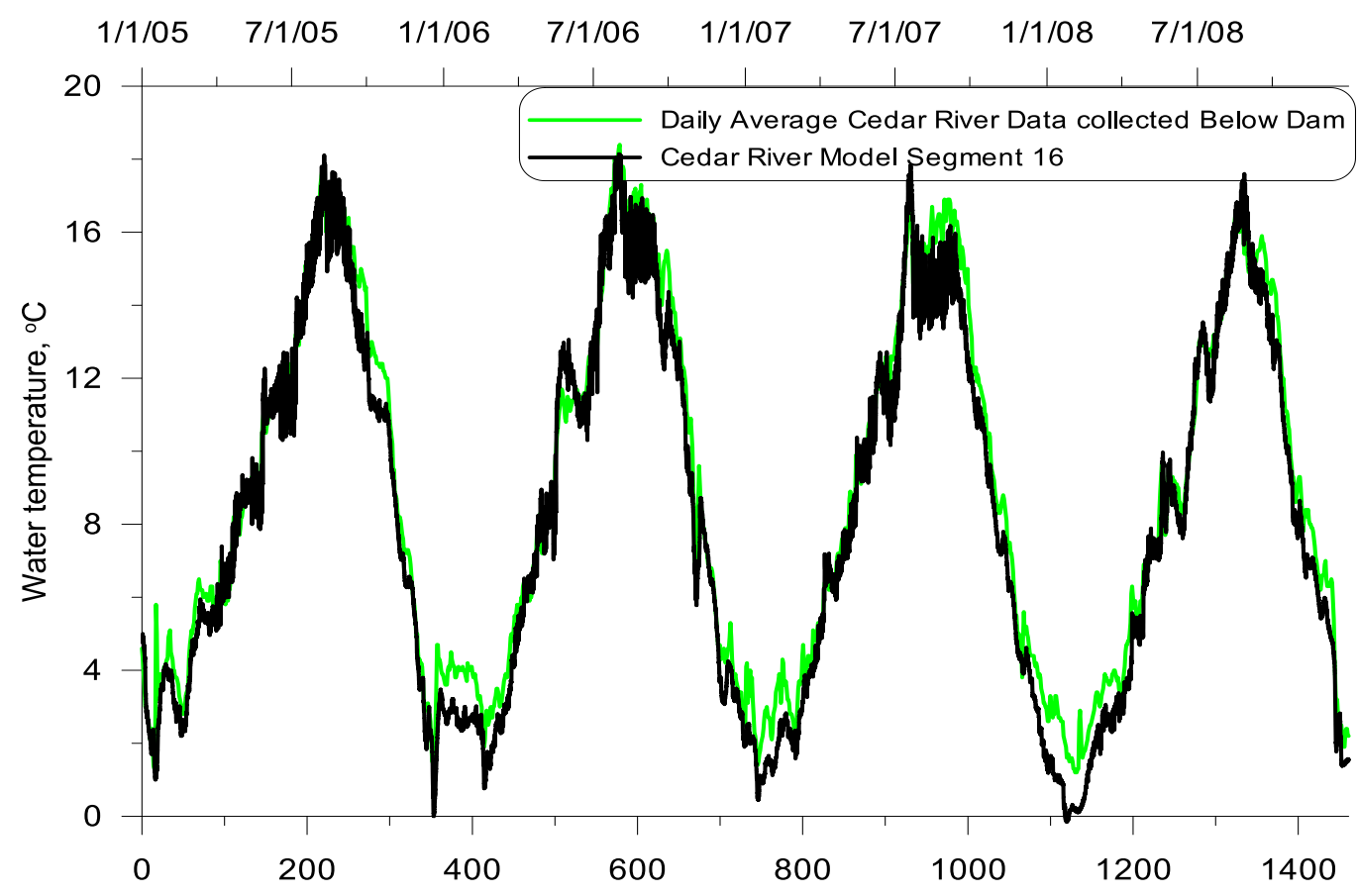

Figure 70. Cedar River model data comparison at location corresponding to model segment 16

The model data comparison of the fully calibrated model at segment 95 is shown in Figure 71. 


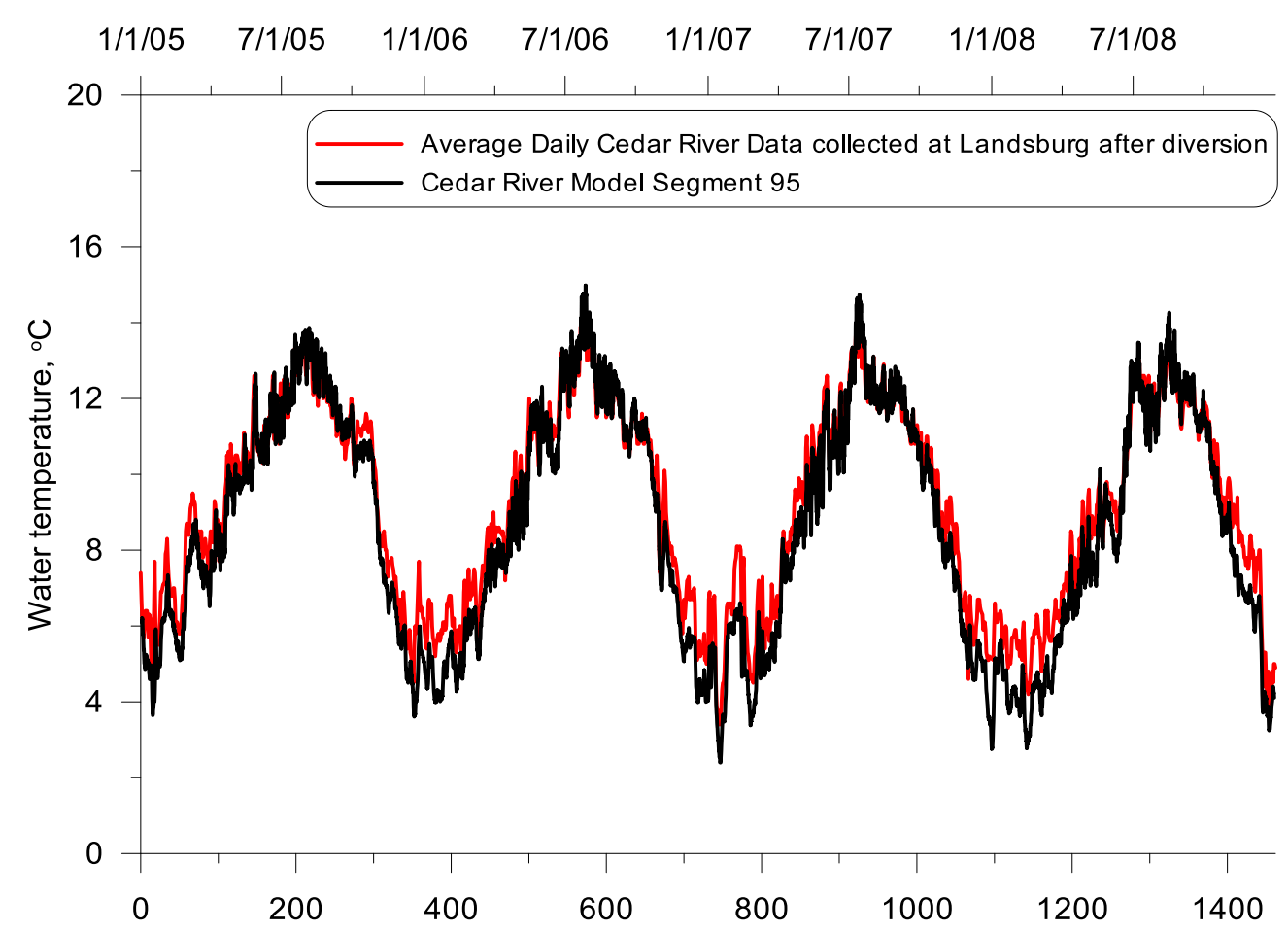

Figure 71. Cedar River model data comparison at location corresponding to model segment 95

The river model error statistics showed an absolute mean error of 0.77 and $0.65^{\circ} \mathrm{C}$ at the two data collections sites, well under the goal of $1.0^{\circ} \mathrm{C}$ or less absolute mean error. The mean error for both sites was negative, indicating a slight bias toward being too cold. The likely origin of these cold winter temperatures is the output from the Chester Morse Lake model, which has a cold bias during the winter. However since this tendency only appeared in the winter months (as can be seen from the above graphs), it is therefore not of too much concern since the period of interest is largely late spring to fall months. The summary of model vs. data error statistics is shown in Table 15. 
Table 15. Cedar River model vs. data error statistics

\begin{tabular}{|c|c|c|c|c|c|}
\hline Location & Segment & $\begin{array}{c}\text { Mean } \\
\text { Error }\end{array}$ & $\begin{array}{c}\text { Absolute } \\
\text { Mean Error }\end{array}$ & $\begin{array}{c}\text { Root Mean } \\
\text { Squared Error }\end{array}$ & $\begin{array}{c}\text { Number of } \\
\text { Comparisons }\end{array}$ \\
\hline $\begin{array}{c}\text { USGS } \\
12116500\end{array}$ & 16 & -0.65 & 0.77 & 0.93 & 1453 \\
\hline $\begin{array}{c}\text { USGS } \\
12117600\end{array}$ & 95 & -0.54 & 0.65 & 0.78 & 1453 \\
\hline
\end{tabular}




\section{Fish Habitat Model}

CE-QUAL-W2 is designed with the capability of calculating temperature-based fish

growth potential zones throughout the model domain. Fish habitat volume analyses were carried out for both Chester Morse Lake and the Cedar River.

\section{Chester Morse Lake Fish Habitat}

The primary species of interest in Chester Morse Lake is Bull Trout, a picture of which is shown in Figure 72.

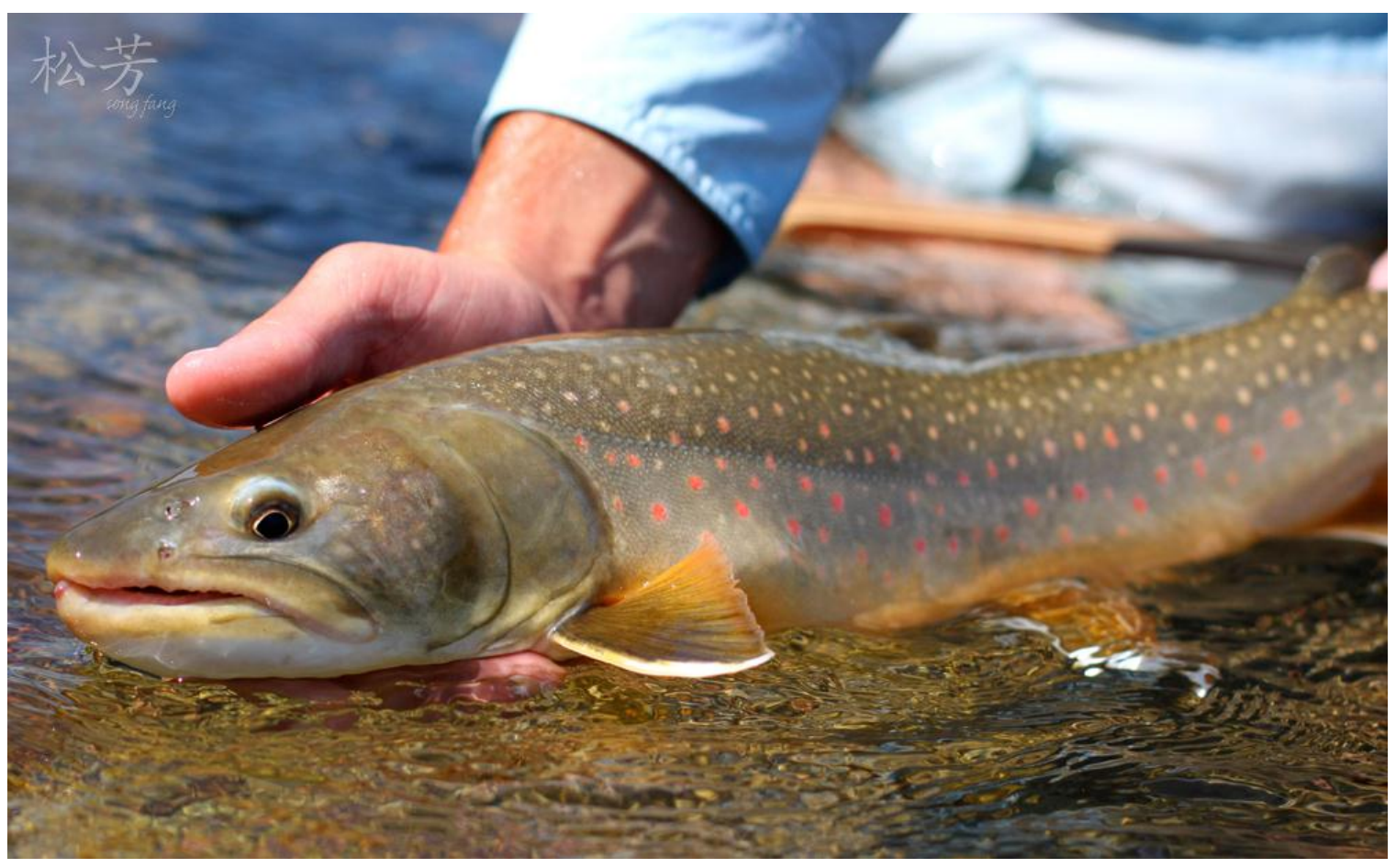

Figure 72. Photograph of bull trout (OutsmartingFish.com (2009))

This cold water species has temperature preferences lower than many other salmonoid species. A temperature versus growth rate curve for bull trout is shown in Figure 73 as calculated from experimental data by Selong et al. (2001). Using this temperature vs. 
growth potential relationship, temperature based growth potential zones were defined for modeling purposes. These zones are outlined in Table 16.

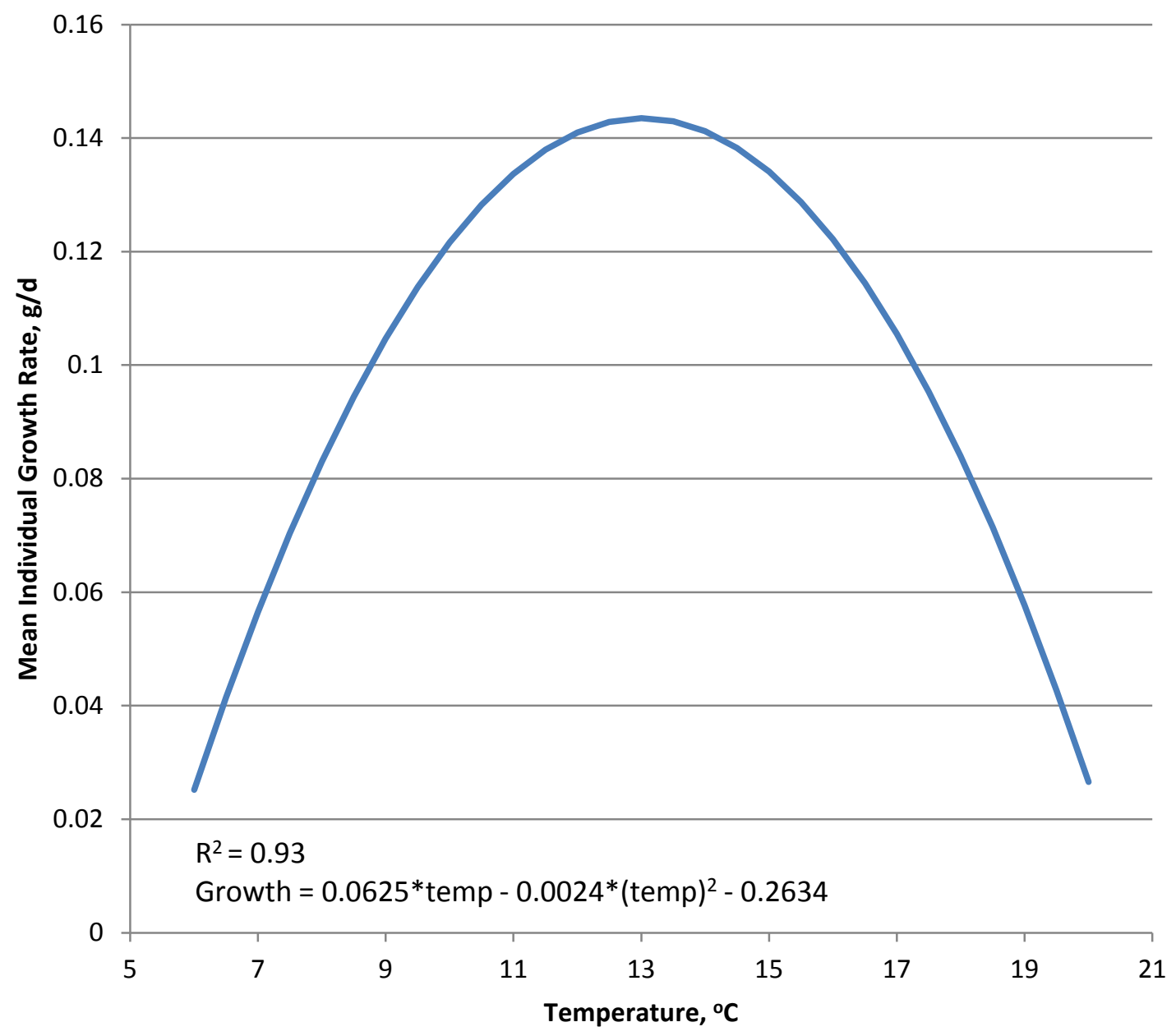

Figure 73. Bull trout growth potential curve from Selong et al. (2001)

Table 16. Bull Trout growth potential zones

Growth Potential Zones

\section{Optimal Growth (more than $0.14 \mathrm{~g} / \mathrm{d}$ )}

High Growth (0.12-0.14 g/d)

Medium Growth $(0.10-0.12 \mathrm{~g} / \mathrm{d})$

Low Growth (less than $0.10 \mathrm{~g} / \mathrm{d}$ )

Non-lethal (no growth)
Temperature Criteria

$11.4-15.2{ }^{\circ} \mathrm{C}$

9.8-17 ${ }^{\circ} \mathrm{C}$

$8.7-18^{\circ} \mathrm{C}$

$6-20^{\circ} \mathrm{C}$

$0-26.4^{\circ} \mathrm{C}$ 
Using these growth temperature criteria, the fully calibrated temperature model was run to output fish habitat zones for the main lake as well as the Masonry Pool separately. Figure 74 and Figure 75 show the fish habitat volumes for the main lake for the complete calibration period between 1/1/2005 and 12/31/2008. Figure 76 and Figure 77 show the fish habitat volumes for the Masonry pool between 1/1/2005 and $12 / 31 / 2008$. 

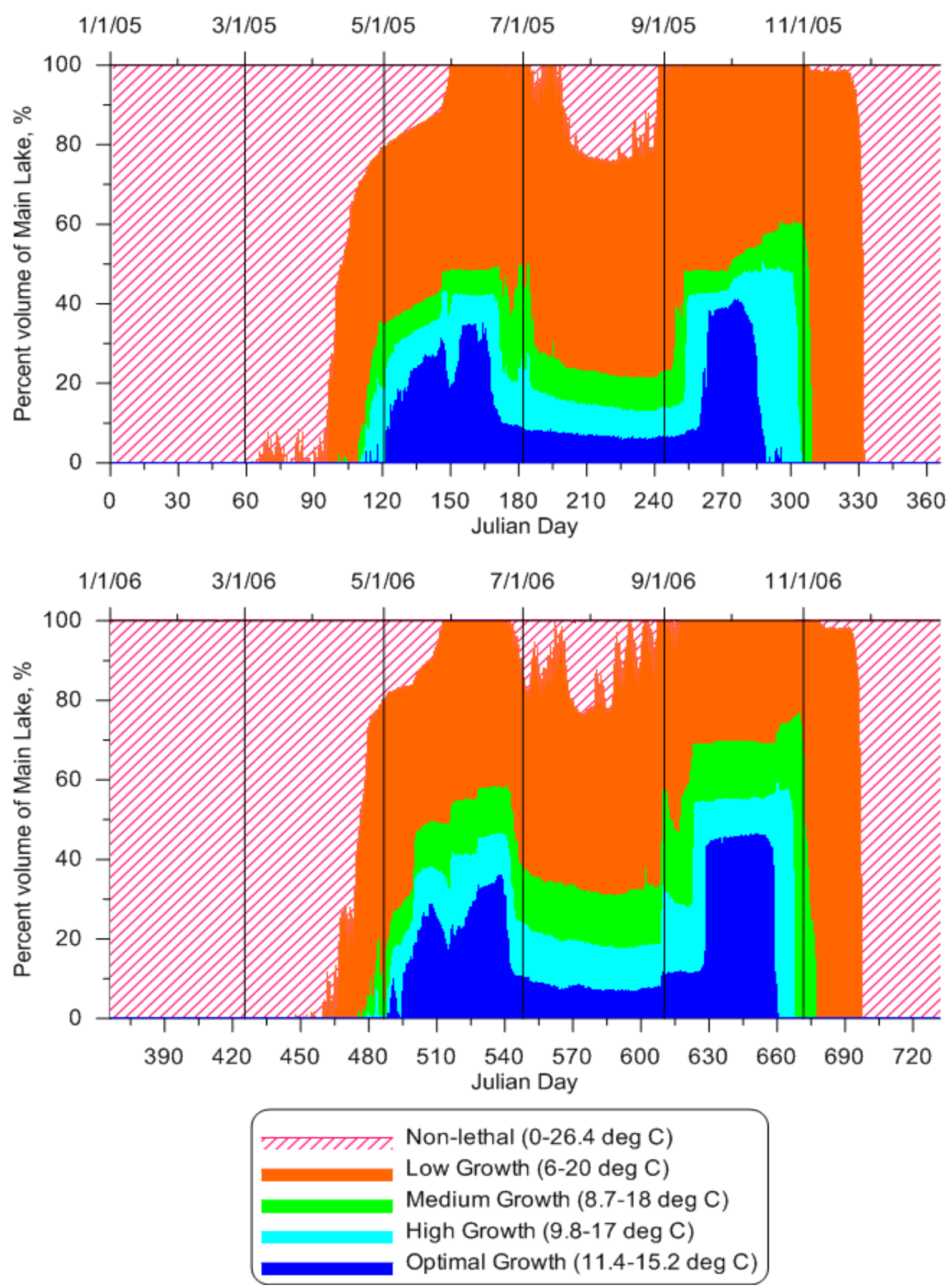

Figure 74. Fish Habitat volumes for Bull Trout in Chester Morse Main Lake - (2005-2006) 

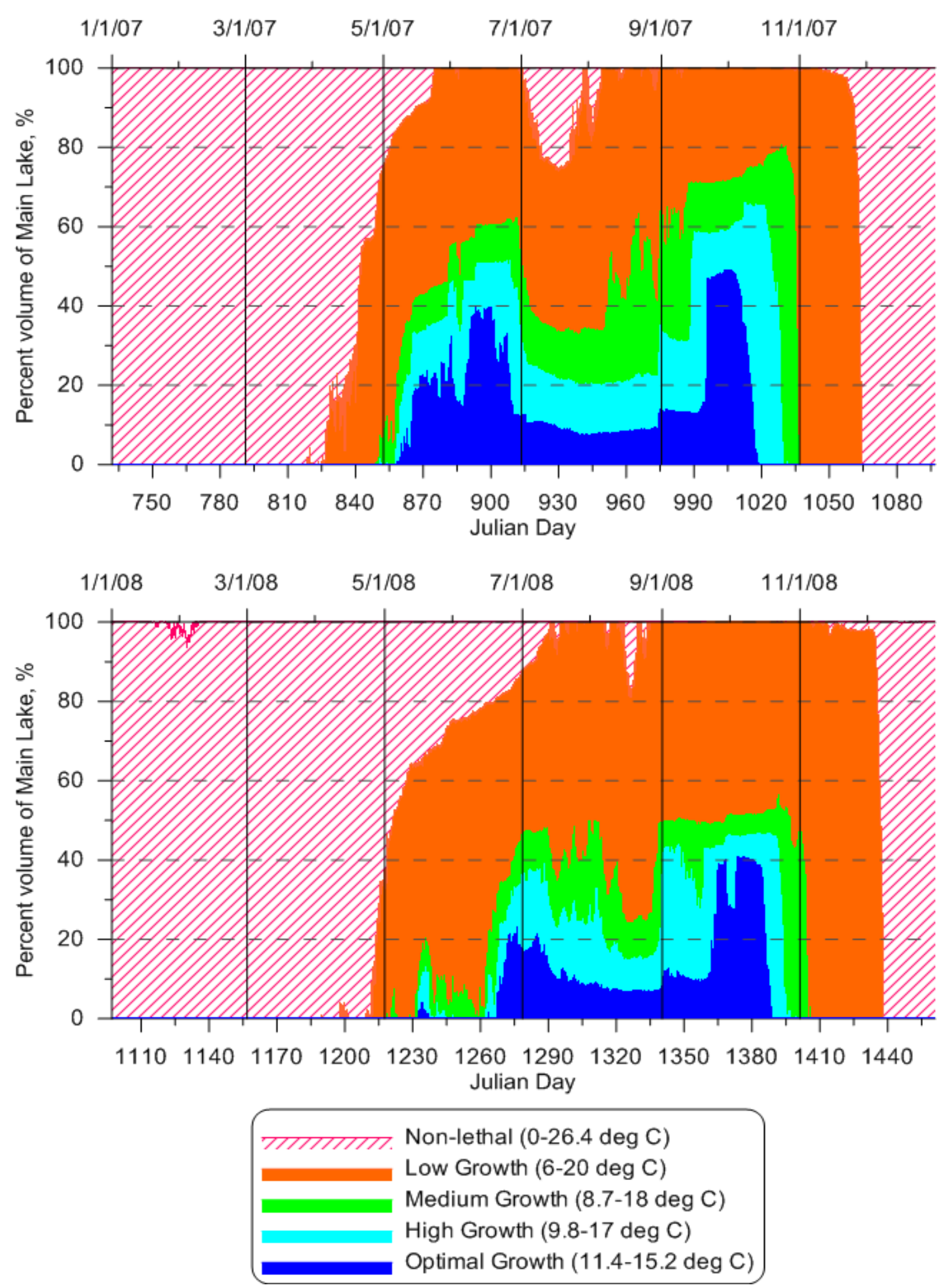

Figure 75. Fish Habitat volumes for Bull Trout in Chester Morse Main Lake - (2007-2008) 

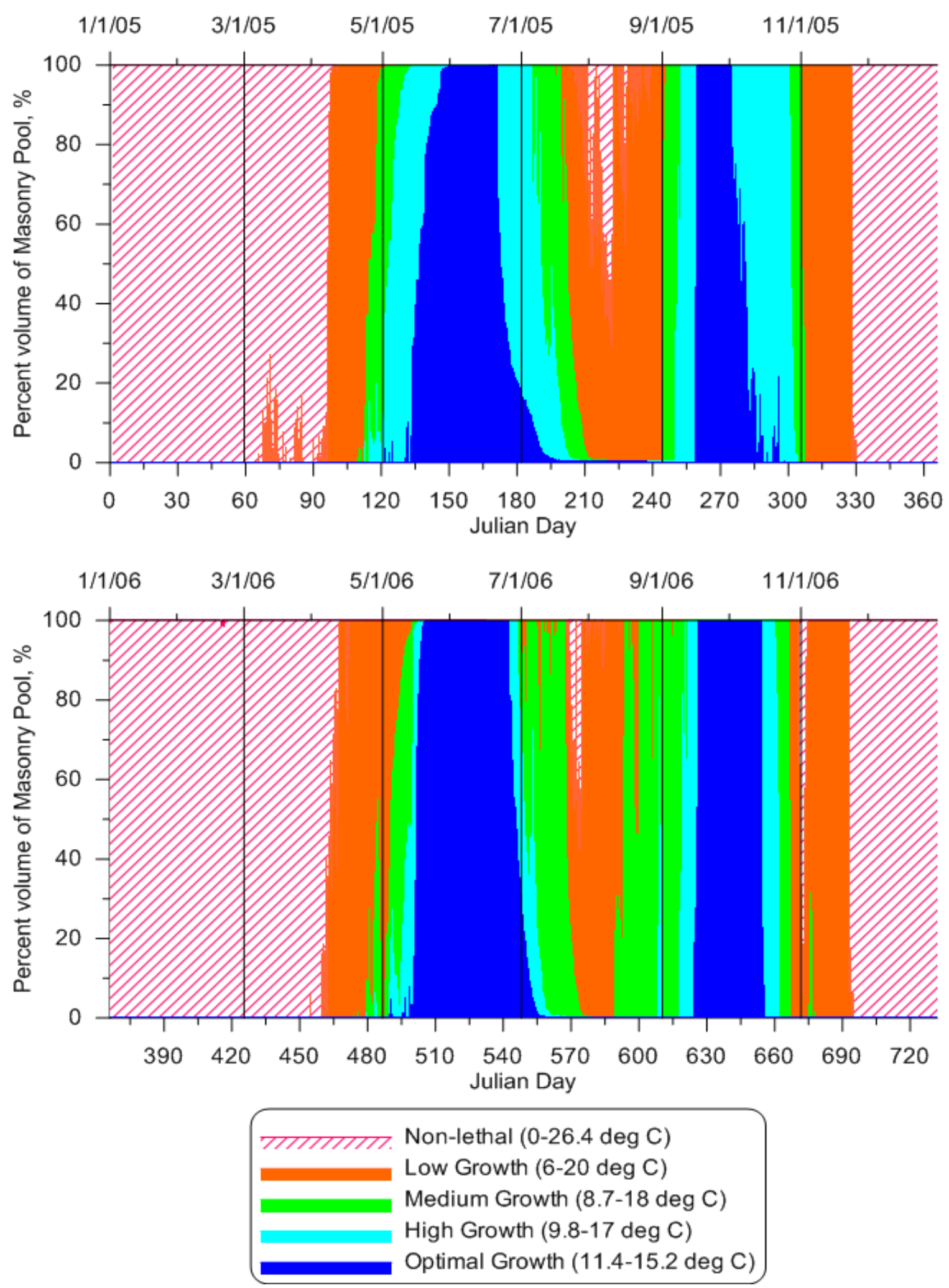

Figure 76. Fish Habitat volumes for Bull Trout in Chester Morse Masonry Pool - (2005-2006) 

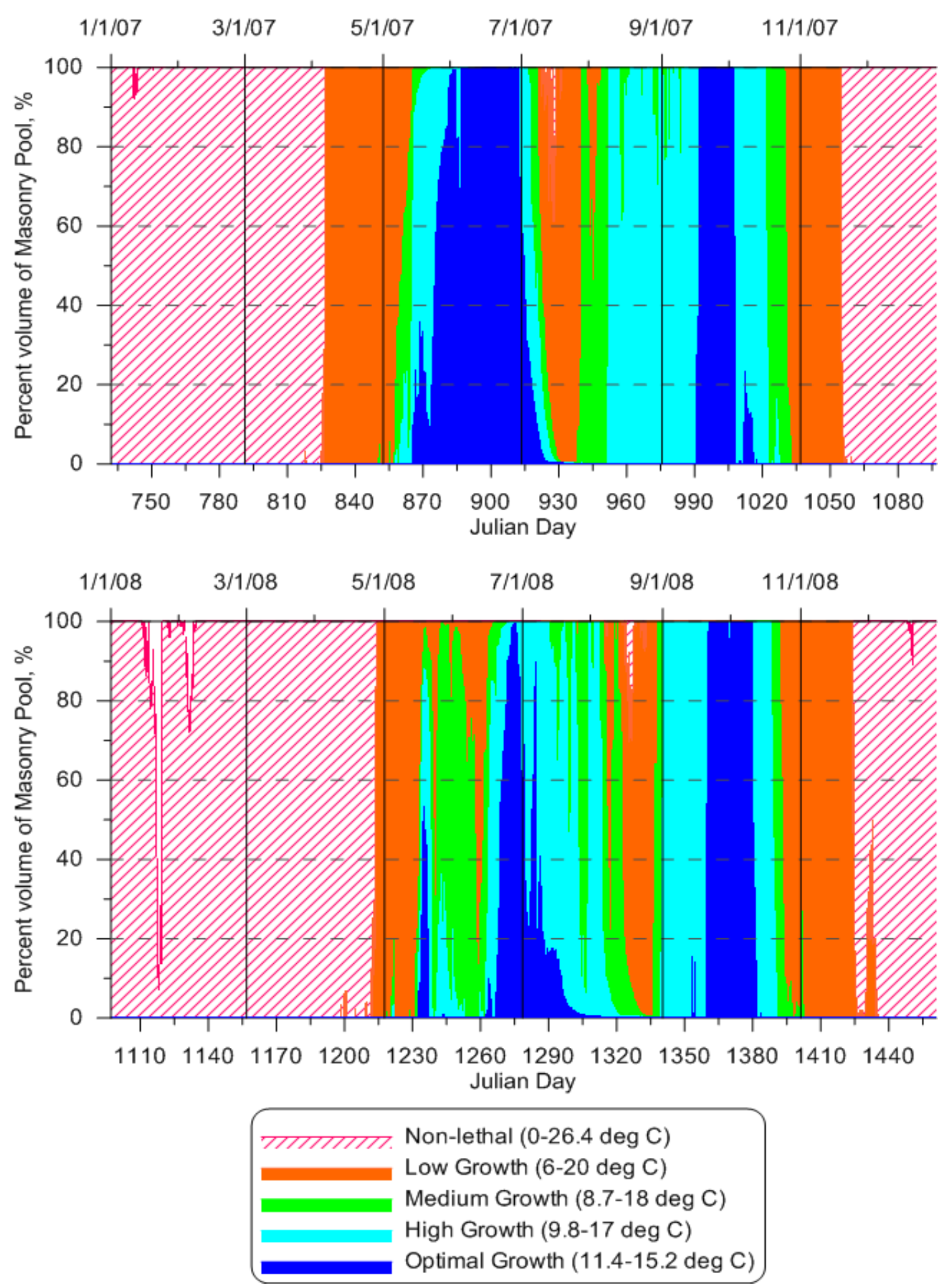

Figure 77. Fish Habitat volumes for Bull Trout in Chester Morse Masonry Pool - (2007-2008) 
As the preceding graphs clearly indicate, most of the volume of the Masonry pool has very favorable conditions for bull trout between the months of May and July. Bull trout migration into the Masonry Pool from the main lake has been observed by fish biologists during this late spring/early summer period. Further research will be done to link model output with actual fish behavior based upon data provided by SPU.

\section{Fish Bioenergetics}

\section{Background}

The fundamental principle of fish bioenergetics is summed up by the following equation by Winberg (1956):

Growth $($ Total growth $)=$ Consumption $($ Energy of consumed food $)-$

\section{Respiration (Total metabolic costs) \\ - Waste (Energy contained in waste products)}

Each of these individual components is impacted by the age, size and species of the fish, as well as by water temperature and food availability. Metabolic and waste energy costs are directly calculable with known fish species, size and water temperature. Total growth and consumption are generally either measured or derived, i.e. if food consumption is known, growth can be calculated and vice versa (McKillip and Wells, 2007). 


\section{Application to Chester Morse Lake Model}

Due to the constraints of the Chester Morse Lake model and the nature of bull trout feeding habits, it was not possible to directly model food availability for this species.

Pigmy whitefish form a considerable portion of the diet of the Chester Morse Lake bull trout. A future goal of this project is to create a fish bioenergetics model of pigmy whitefish to then be able to estimate the bull trout food supply. Until such a model is created, the consumption parameter in the bull trout fish bioenergetics equation must be estimated.

The fish bioenergetics code used in this study was first developed in 2007 by Dr. Michael L. McKillip, and used in conjunction with a CE-QUAL-W2 model of Lake Roosevelt in Washington State to estimate growth rates for various salmon species (McKillip and Wells, 2007). The code has been adapted to the temperature preferences of bull trout, and formulated to assume satiation rations. The bioenergetics parameters used by this model are summarized in Table 17.

Table 17. Bioenergetics parameters (McKillip and Wells, 2007)

\begin{tabular}{|c|c|c|}
\hline Parameter & Symbol & Units \\
\hline Consumption & $\mathrm{C}$ & \#/min (prey) \\
\hline Digestion & $\mathrm{D}$ & $\mathrm{J}$ (per timestep) \\
\hline Excretion & $\mathrm{U}$ & $\mathrm{J}$ (per timestep) \\
\hline Egestion & $\mathrm{F}$ & $\mathrm{J}$ (per timestep) \\
\hline Respiration & $\mathrm{R}$ & $\mathrm{J}$ (per timestep) \\
\hline SDA & $\mathrm{S}$ & $\mathrm{J}$ (per timestep) \\
\hline Growth & $\mathrm{G}$ & $\mathrm{g}$ (per day) \\
\hline
\end{tabular}


Daily fish growth is computed by taking the sum of the parameters shown in Equation 5.

Equation 5. Growth parameter (McKillip and Wells, 2007)

$$
\begin{gathered}
\mathrm{G}=\frac{1}{\mathrm{E}_{\text {fish }}} \sum_{\text {day }}(\mathrm{D}-\mathrm{U}-\mathrm{F}-\mathrm{R}-\mathrm{S}) \\
\mathrm{G}=\frac{[\mathrm{J}]}{\left[\mathrm{J} \cdot \mathrm{g}^{-1}\right]} \\
\mathrm{G}=\mathrm{g} \text { (per day) }
\end{gathered}
$$

The parameter $E_{\text {fish, }}$ fish energy density, is calculated using Equation 6.

Equation 6. Fish energy density (McKillip and Wells, 2007)

$$
\mathrm{E}_{\text {fish }}[\mathrm{J} / \mathrm{g}]=\left\{\begin{array}{lll}
4.1868 \cdot(1.8510 \cdot \mathrm{M}+1250) & \text { for } & \mathrm{M} \leq 196 \mathrm{~g} \\
4.1868 \cdot(1.1254 \cdot \mathrm{M}+1588) & \text { for } & \mathrm{M}>196 \mathrm{~g}
\end{array}\right.
$$

The first major component to fish growth is the digestion parameter. This parameter takes into account stomach contents at the beginning of a timestep, the prey consumed during that timestep, and the remaining energy content of the stomach contents at the end of the timestep. The digestion parameter calculation is shown in Equation 7. The variables are explained in

Table 18.

Equation 7. Digestion parameter (McKillip and Wells, 2007)

$$
\begin{aligned}
& \mathrm{D}=\left((\underbrace{\mathrm{M}_{\mathrm{o}}}_{\text {initialcontent }}+\underbrace{\left.\mathrm{C} \cdot \mathrm{m}_{\mathrm{z}} \cdot \mathrm{t}\right) \cdot \mathrm{TL}}_{\text {consumptian }})-(\underbrace{\mathrm{M}_{\mathrm{o}} \mathrm{e}^{-r \cdot t / 60}+\frac{\mathrm{C} \cdot \mathrm{m}_{\mathrm{z}} \cdot 60 \cdot \mathrm{TL}}{\mathrm{r}}\left(1-e^{-r \cdot t / 60}\right)}_{\text {undigestedcontents }})\right) \cdot E_{\text {prey }} \\
& \mathrm{D}=\left(\left(\mathrm{g}-\mathrm{wet}+\left(\frac{\#}{\mathrm{~min}} \cdot \mathrm{g}-\mathrm{wet} \cdot \mathrm{min}\right)\right)-\left(\mathrm{g}-\mathrm{wet}+\frac{\#}{\mathrm{~min}} \cdot \mathrm{g}-\mathrm{wet} \cdot \min \right)\right)\left(\frac{\mathrm{J}}{\mathrm{g}-\mathrm{wet}}\right)
\end{aligned}
$$




$$
\mathrm{D}=[\mathrm{J}] \text { (per timestep) }
$$

Table 18. Digestion parameter variables (McKillip and Wells, 2007)

\begin{tabular}{|l|l|l|}
\hline Variable & Units & Definition \\
\hline $\mathbf{M}_{\mathbf{0}}$ & g-wet & Initial stomach content \\
\hline $\mathbf{C}$ & $\begin{array}{l}\text { \#/min (e.g., } \\
\text { Daphnia) }\end{array}$ & Consumption \\
\hline $\mathbf{m}_{\mathbf{z}}$ & g-wet & $\begin{array}{l}\text { mass of a single prey } \\
\text { zooplankton }\end{array}$ \\
\hline $\mathbf{t}$ & (30) minutes & Timestep \\
\hline $\mathbf{T L}$ & dimensionless & Thornton-Lessem function \\
\hline $\mathbf{r}$ & dimensionless & digestion coefficient \\
\hline $\mathbf{E}_{\text {prev }}$ & J/g-wet & Prey energy content (density) \\
\hline $\mathbf{6 0}$ & minutes & unit conversion factor \\
\hline
\end{tabular}

One key parameter in the digestion equation is consumption. The approach used to estimate consumption by this model is shown in Equation 8. An explanation of the consumption parameter variables is shown in

Table 19.

Equation 8. Consumption parameter (McKillip and Wells, 2007)

$$
\begin{gathered}
\mathrm{C}=\frac{E \cdot z}{1+E \cdot z \cdot h} \cdot T L \cdot 60 \\
\mathrm{C}=\frac{\mathrm{m}^{3} / \mathrm{s} \cdot \frac{\#}{\mathrm{~m}^{3}}}{\mathrm{~m}^{3} / \mathrm{s} \cdot \frac{\#}{\mathrm{~m}^{3}} \cdot \frac{\mathrm{s}}{\#}} \cdot \frac{60 \mathrm{~s}}{\min } \\
\mathrm{C}=\left[\frac{\#}{\mathrm{~min}}\right] \text { ("prey" per timestep) }
\end{gathered}
$$


Table 19. Consumption parameter variables, (McKillip and Wells, 2007)

\begin{tabular}{|l|l|l|}
\hline Variable & Units & Definition \\
\hline $\mathbf{R}_{\mathbf{d}}$ & $\mathrm{m}$ & Predator reaction distance \\
\hline lux & lux & Ambient light intensity \\
\hline $\mathbf{E}$ & $\mathrm{m}^{3} / \mathrm{s}$ & Search rate \\
\hline $\mathbf{v}$ & $\mathrm{m} / \mathrm{s}$ & fish swimming speed \\
\hline $\mathbf{z}$ & $\# / \mathrm{m}^{3}$ & prey density \\
\hline $\mathbf{h}$ & $\# / \mathrm{s}$ & handling time \\
\hline $\mathbf{T L}$ & dimensionless & $\begin{array}{l}\text { Thornton-Lessem } \\
\text { function }\end{array}$ \\
\hline $\mathbf{6 0}$ & s / min & unit conversion factor \\
\hline
\end{tabular}

Equation 9 and Equation 10 show the methods used for calculating egestion and excretion parameters, respectively.

Equation 9. Egestion parameters (McKillip and Wells, 2007)

$$
\begin{gathered}
\mathrm{F}=0.455 \cdot \mathrm{T}^{-0.222} \cdot \mathrm{D} \\
\mathrm{F}=\left(\frac{1}{{ }^{\circ} \mathrm{C}}\right){ }^{\circ} \mathrm{C} \cdot \mathrm{J}=\mathrm{J} \\
\mathrm{F}=[\mathrm{J}] \text { (per timestep) }
\end{gathered}
$$

Equation 10. Excretion parameter (McKillip and Wells, 2007)

$$
\begin{gathered}
\mathrm{U}=0.0233 \cdot \mathrm{T}^{0.58} \cdot(\mathrm{D}-\mathrm{F}) \\
\mathrm{U}=\left(\frac{1}{{ }^{\circ} \mathrm{C}}\right){ }^{\circ} \mathrm{C} \cdot \mathrm{J}=\mathrm{J} \\
\mathrm{U}=[\mathrm{J}] \text { (per timestep) }
\end{gathered}
$$

The final major component of the bioenergetics equation, respiration, is calculated

using Equation 11. The respiration parameter variables are described in Table 20. 
Equation 11. Respiration parameter (McKillip and Wells, 2007)

$$
\begin{gathered}
\mathrm{R}=0.00143 \cdot \mathrm{M}^{-0.209} \cdot \mathrm{e}^{0.086 \mathrm{~T}} \cdot \mathrm{ACT} \cdot \mathrm{OXYCAL} \cdot \frac{\mathrm{t}}{\mathrm{t}_{\mathrm{day}}} \cdot \mathrm{M} \\
\mathrm{R}=\frac{\mathrm{g}-\mathrm{O}_{2}}{(\sim \mathrm{g}-\mathrm{fish}) \cdot(\sim \mathrm{g}-\text { fish })^{-0.209}}(\sim \mathrm{g}-\mathrm{fish})^{-0.209} \frac{\mathrm{J}}{\mathrm{g}-\mathrm{O}_{2}} \cdot \frac{\mathrm{min}}{\min } \cdot \mathrm{g}-\text { fish } \\
\mathrm{R}=\left[\frac{\mathrm{J}}{\mathrm{g}-\text { fish }} \cdot \mathrm{g}-\text { fish }\right]=[\mathrm{J}] \text { (per timestep) }
\end{gathered}
$$

Table 20. Respiration parameter variables (McKillip and Wells, 2007)

\begin{tabular}{|l|l|l|}
\hline Variable & Units & Definition \\
\hline $\mathbf{M}$ & g-wet & Fish mass \\
\hline $\mathbf{T}$ & deg. C & Temperature \\
\hline ACT & dimensionless & Activity \\
\hline OXYCAL & J / g-O 2 & Oxycaloric conversion factor \\
\hline $\mathbf{t}$ & $(30)$ minutes & Timestep \\
\hline $\mathbf{t}_{\text {day }}$ & $(1440)$ minutes & Duration of a day \\
\hline
\end{tabular}


The fish bioenergetics parameters for bull trout were provided by Dave Beauchamp from research work done by Matt Mesa at USGS Columbia River Lab in Cook, WA. These parameters are shown in Table 21.

Table 21. Bull trout consumption parameters (Matt Mesa et al., 2011)

Description of parameters (Bliesner, 2005)

\begin{tabular}{|c|c|c|}
\hline Parameter & $\begin{array}{c}\text { Bull Trout Parameter } \\
\text { Values }\end{array}$ & Description of Parameter \\
\hline $\mathrm{CA}$ & 0.1345 & $\begin{array}{l}\text { Intercept of allometric mass } \\
\text { function }\end{array}$ \\
\hline $\mathrm{CB}$ & -0.1396 & Slope of allometric mass function \\
\hline CK1 & 0.1 & Model parameter \\
\hline $\mathrm{CQ}$ & 3.4 & Approximation of $Q_{10}$ value \\
\hline СТO & 17 & $\begin{array}{c}\text { The water temperature at which } \\
\text { consumption if optimum }\end{array}$ \\
\hline CTM & 17 & $\begin{array}{l}\text { The maximum temperature at } \\
\text { which consumption occurs }\end{array}$ \\
\hline CTL & 24 & Model parameter \\
\hline CK4 & 0.26 & Model parameter \\
\hline
\end{tabular}

The bull trout growth results from segments 23 (mid-lake) and 64 (Masonry Pool) using the above parameters and a fixed fish mass of 75 grams are shown in Figure 78 . The model was run at various food availability levels $-100 \%$ indicating food availability at 
$100 \%$ of satiation rations, $50 \%$ indicating food availability at $50 \%$ of satiation rations,

etc.
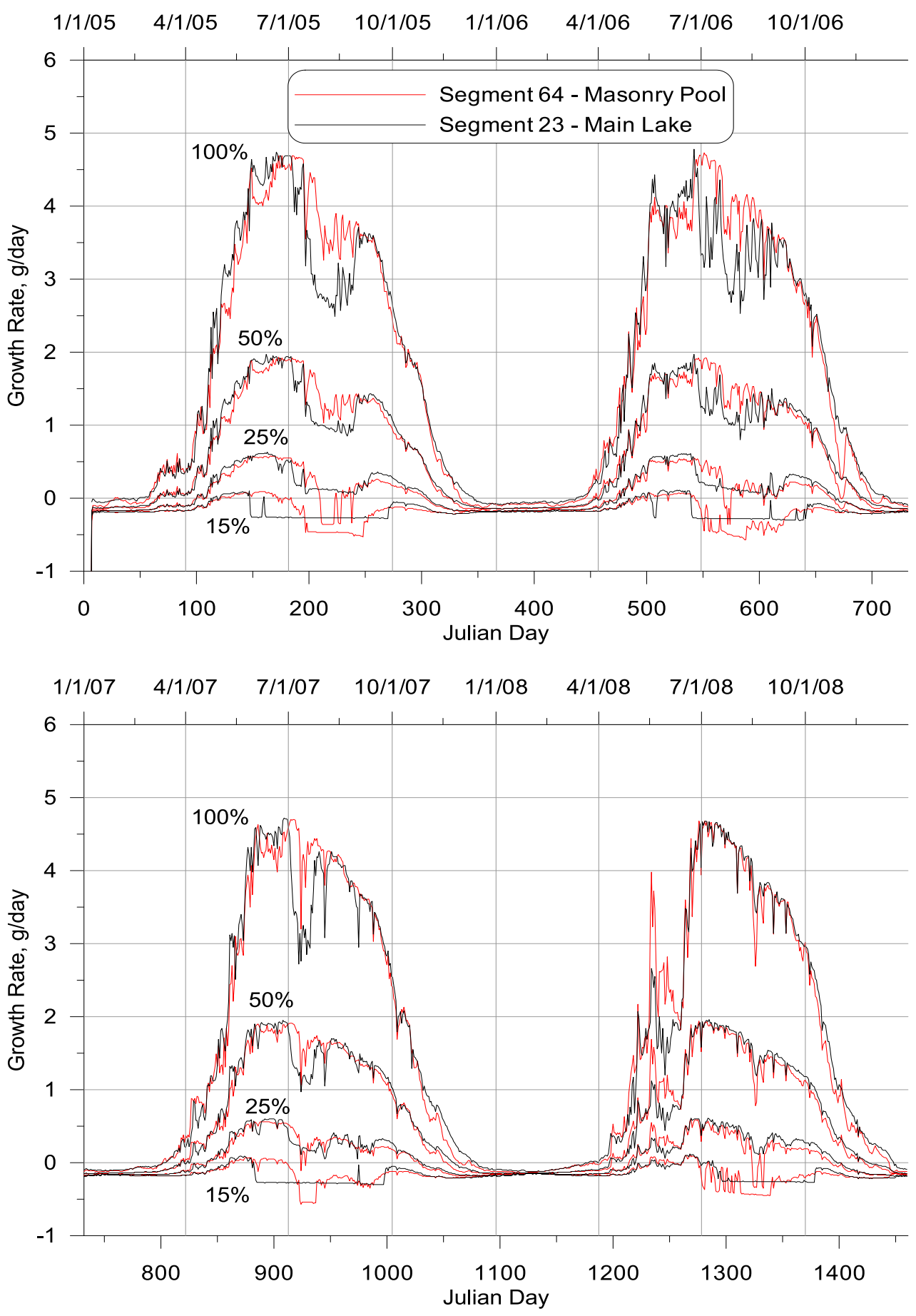

Figure 78. Fish bioenergetics growth results with fixed mass at model segments 23 and 64 
The bull trout growth results from segments 23 (mid-lake) and 64 (Masonry Pool) using the above parameters and a model calculated variable mass are shown in Figure 79.
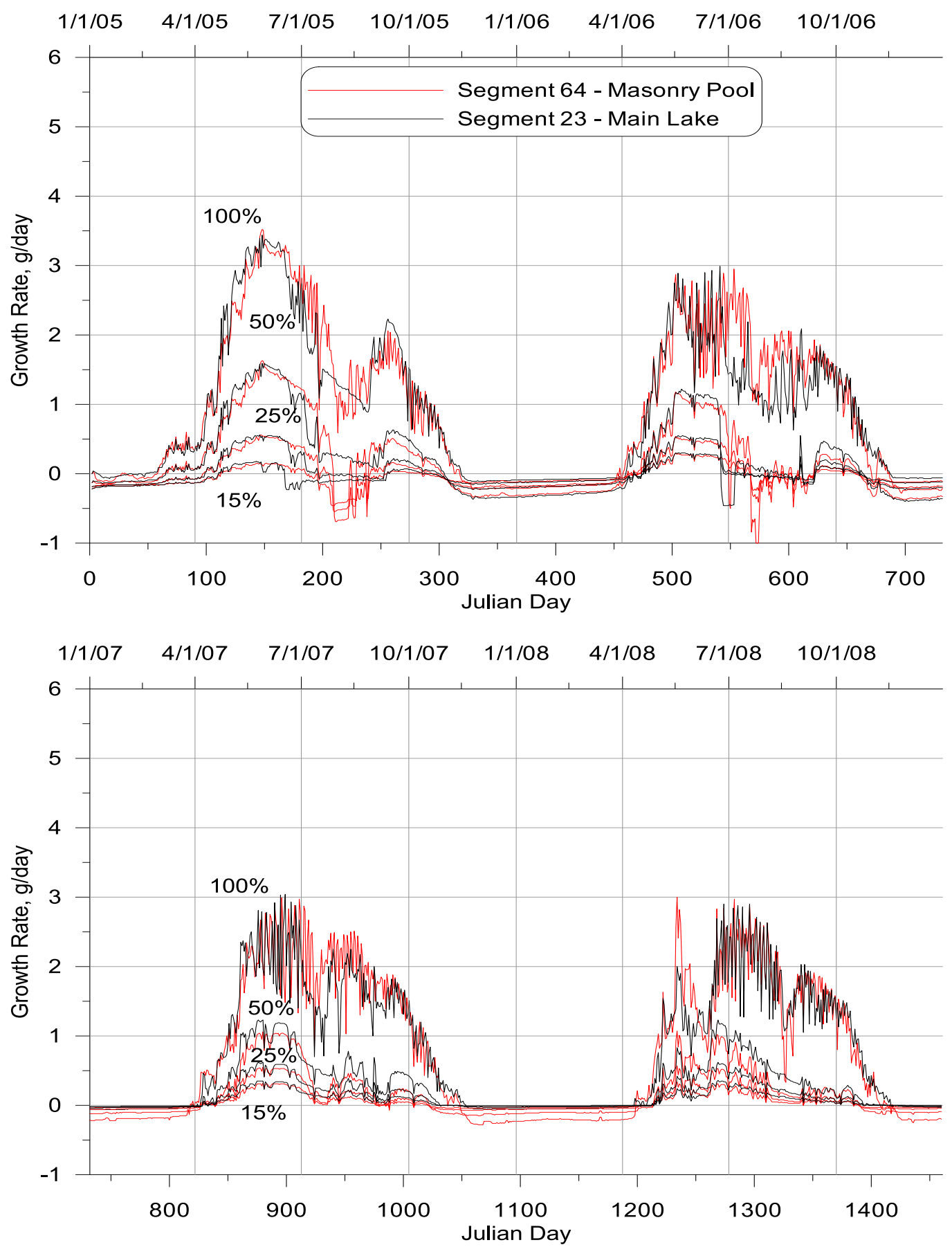

Figure 79. Fish bioenergetics growth results with model calculated mass at model segments 23 and 64 
Bull trout mass model results at segments 23 and 64 are shown in Figure 80.
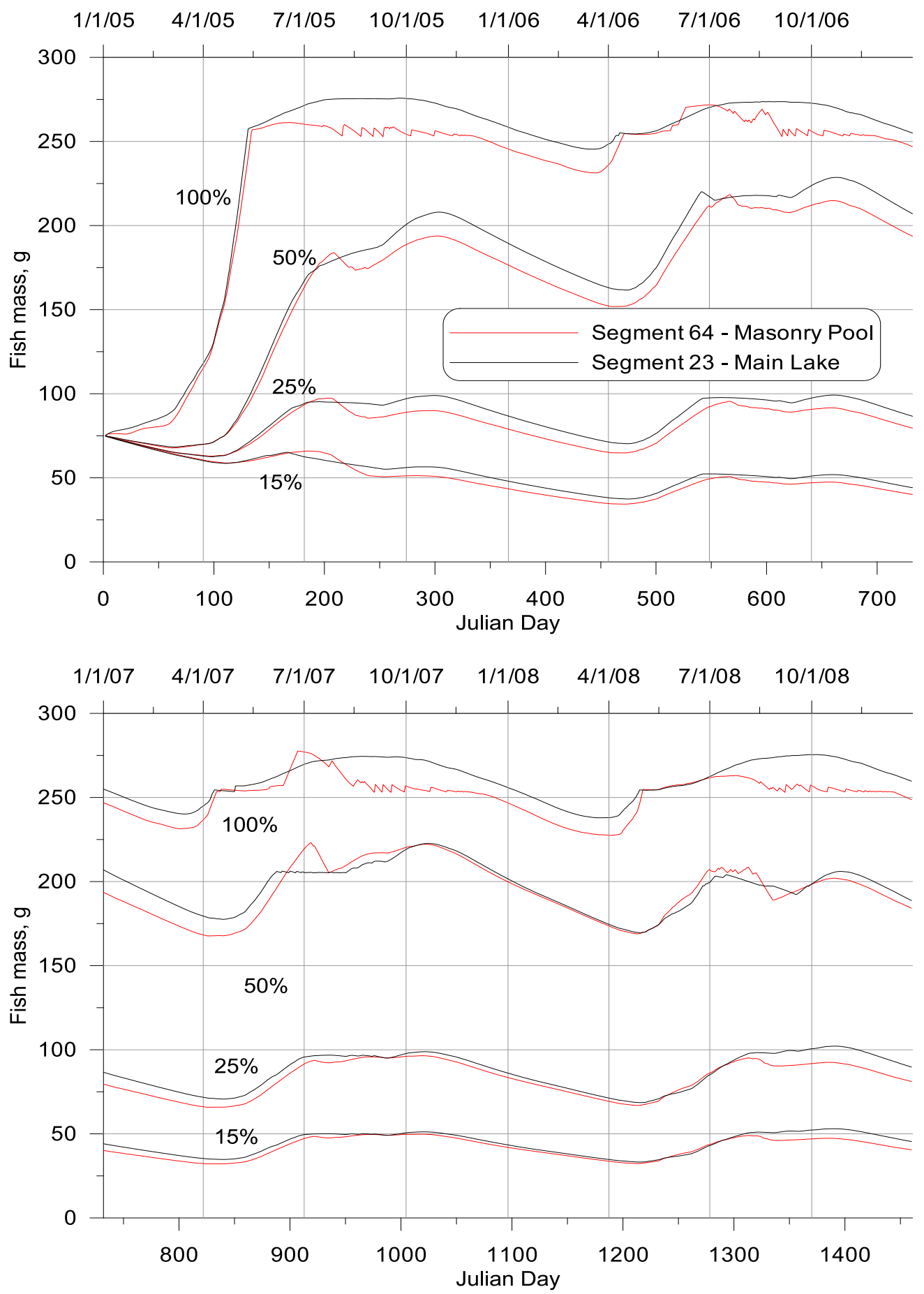

Figure 80. Fish bioenergetics mass results at model segments 23 and 64 


\section{Discussion of Bioenergetics Results}

The food availability conditions best representing actual conditions in Chester Morse Lake likely fall between the $15 \%$ to $25 \%$ ranges. According to the fish biologists studying the resident bull trout in Chester Morse Lake, they are subsisting on what are very close to starvation rations (Paige, 2011). This indicates that temperature, although also an important factor, is not the limiting factor in this system.

As illustrated in the three proceeding figures, however, temperature is certainly a key component in estimating fish growth during the year. Winter cold temperatures cause fish - regardless of food availability - to experience negative growth and lose weight. As the spring approaches, growth increases - generally starting in early April - with some variability between years depending on temperature conditions. How much they grow depends both on food availability and water temperature. An example of the impact of water temperature can be seen in the final year of the model, 2008. During this year Chester Morse Lake experienced very cold spring water temperatures, which considerably dampened growth rates all the way into June, when compared to the other three model years.

Some variability is also seen between locations. During different parts of the year growth potential conditions are either better in the Masonry Pool or the main lake. During most of the year, with the exception of late summer when the two pools separate, fish are able to travel back and forth between the Masonry Pool and main lake. Their location preference is likely most linked to the combination of both food 
availability and temperature conditions. In order to accurately capture this dynamic, it would be necessary to model the bull trout's food source as well, as was mentioned earlier. 


\section{Summary and Conclusions}

A CE-QUAL-W2 hydrodynamic and temperature model of Chester Morse Lake and the Cedar River were built using the following:

1. bathymetry data and river transects

2. local meteorological data

3. flow and temperature inflow data from USGS stations and SPU

These two models were run for a 4 year calibration period between 1/1/2005 and $12 / 31 / 2008$. They were calibrated using various calibration parameters such as wind sheltering coefficients, and heat exchange coefficients. The goal for temperature models of this sort is to maintain an absolute mean error of less than $1^{\circ} \mathrm{C}$ (Cole and Wells, 2000). The Chester Morse Lake model returned absolute mean error statistics of less than $1^{\circ} \mathrm{C}$ at all but one time-series temperature recording station. The anomalous station was very close to the Cedar River inflow, and was possible impacted by inaccurate temperature inflow readings. The lake model showed no significant bias as mean error temperatures were very close to zero. The Cedar River model was calibrated using the final calibration results of the Chester Morse Lake model. Very little calibration was necessary for the river model and final calibration absolute error statistics were below $0.8^{\circ} \mathrm{C}$. The river model did show some negative bias during the cold winter months, but showed very little in the critical spring through fall period. 
A habitat analysis focused on the temperature preferences of Bull Trout was evaluated using the Chester Morse Lake model. The resulting habitat volumes and locations corresponded well to anecdotal information from fish biologists about fish movements and preferences during the summer season in Chester Morse Lake. These model results helped explain why bull trout might find better habitat in the Masonry Pool during the summer months, than in the main pool. When SPU provides additional fish data, an explicit analysis and comparison between model predicted fish preferences and data will be carried out.

The results of the bull trout fish bioenergetics model show promising potential for quantifying the impact of various temperature conditions. This model will continue to be refined, and in the future additional pieces will be added to allow for modeling not only temperature, but also food-based growth dynamics.

With the current set of models in place, future tasks with the models could include:

1. Analyze fish habitat for the Cedar River with focus on salmon populations, contingent on addition information from SPU biologists

2. Compare model based fish habitat in Chester Morse Lake with observed fish behavior from tagged bull trout, waiting for data from SPU

3. Incorporate other water quality parameters into CE-QUAL-W2 including nutrient loadings, algae, turbidity, fish-bioenergetics model for pigmy whitefish (a major food source for bull trout) 
4. Develop various management model scenario alternatives for SPU - dependent on input from SPU 


\section{References}

Annear, Rob; and Wells, S. (2007) "A comparison of five models for estimating clear-sky solar radiation." Water Resources Research. Vol. 43, W10415.

Berger, C., and Wells, S. (2011)"Thermalito model development and calibration report." Technical Report. Portland State University.

Bing, Inc. (2009) Bing Maps. Accessed: 7/1/2009. http://www.bing.com/maps/.

Bliesner, K. L. (2005) "Trophic Ecology and Bioenergetics Modeling of Scramento Perch (Archoplites interruptus) in Abbots Lagoon, Point Reyes Nation Seashore." Master's Thesis. Humbolt State University.

Cole, T., and Wells S. (2000) CE-QUAL-W2: “A Two-Dimensional, Laterally Averaged, Hydrodynamic and Water Quality Model, Version 3.0." Instruction Report EL-OO1. Waterways Experiments Station, U.S. Army Corps of Eng., Vicksburg, MS.

Google Inc. (2009). Google Earth (Version 5.1.3533.1731) [Software]. Available from: http://www.google.com/earth/index.html.

Matt Mesa et al. (2011) "Bull trout bioenergetics model parameters for Wisconsin model framework." Manuscript still in preparation. USGS Columbia River Lab, WA.

McKillip, M. L.; and Wells, S. (2007) “Lake Roosevelt Water Quality and Hydrodynamic Model Calibration with Fish Bioenergetics." Technical Report EWR-03-06, Department of Civil and Environmental Engineering, Portland State University. Portland, Oregon.

Outsmarting Fish.com. (2009) "Up North: More Bull Trout." Accessed 9/1/2011. http://outsmartingfish.com/2009/07/up-north-more-bull-trout.

Paige, Dwayne (2009-2011) Personal Communications. Seattle Public Utilities.

Selong, J.H; McHahon, T.E.; Zale, A.; and Barrows, F.T. (2001) "Effect of Temperature on Growth and Survival of Bull Trout with Application of an Improved Method for Determining Thermal Tolerance in Fishes." Transactions of the American Fisheries Society 130:1026-1037. 
Stein, Alan J. (2000) "Cedar River Watershed (King County) - Environmental Overview" Rivers in Time Project. History Link File \#2486.

http://www.historylink.org/index.cfm?DisplayPage=output.cfm\&File Id=2486

United States Geologic Survey. Lake Washington Basin Map PDF. Accessed 4/1/2009 http://wa.water.usgs.gov/data/realtime/adr/interactive/maps/ LakeWashingtonSC basin.pdf.

United States Geologic Survey. Lake Washington Basin Schematic PDF. Accessed 4/1/2009 http://wa.water.usgs.gov/data/realtime/adr/interactive/schematics /LWashington.pdf. 


\section{Appendix}

Chester Morse Lake temperature data comparisons

\section{Time Series Buoy Data}

Figure 81 through Figure 137 show data model time series comparisons for all buoy locations at which temperature data were collected in Chester Morse Lake. They are shown in order of buoy number and increasing depth.

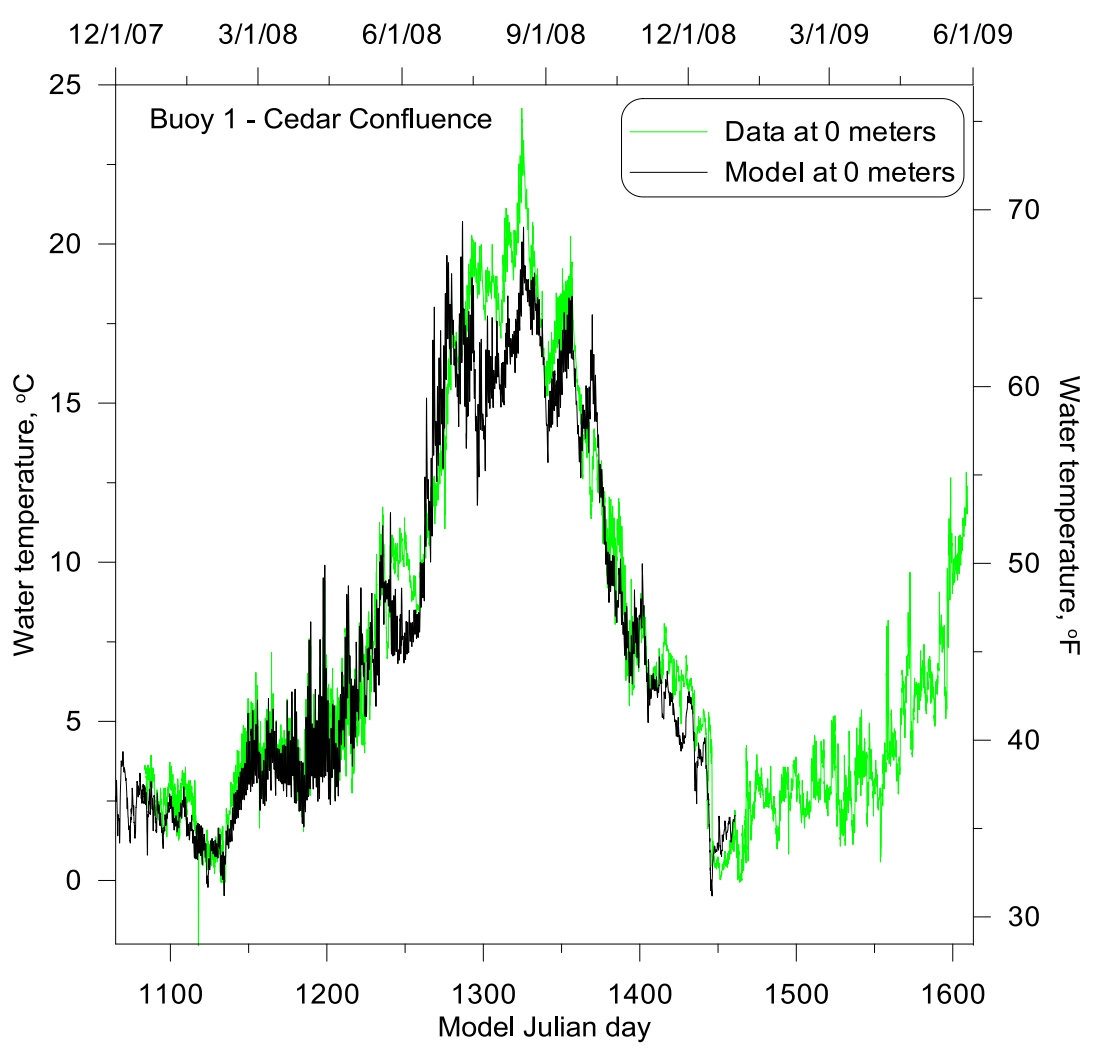

Figure 81. Model vs. data temperature comparison at Buoy 1 (corresponding to model segment 9) Cedar River Confluence - at water surface 


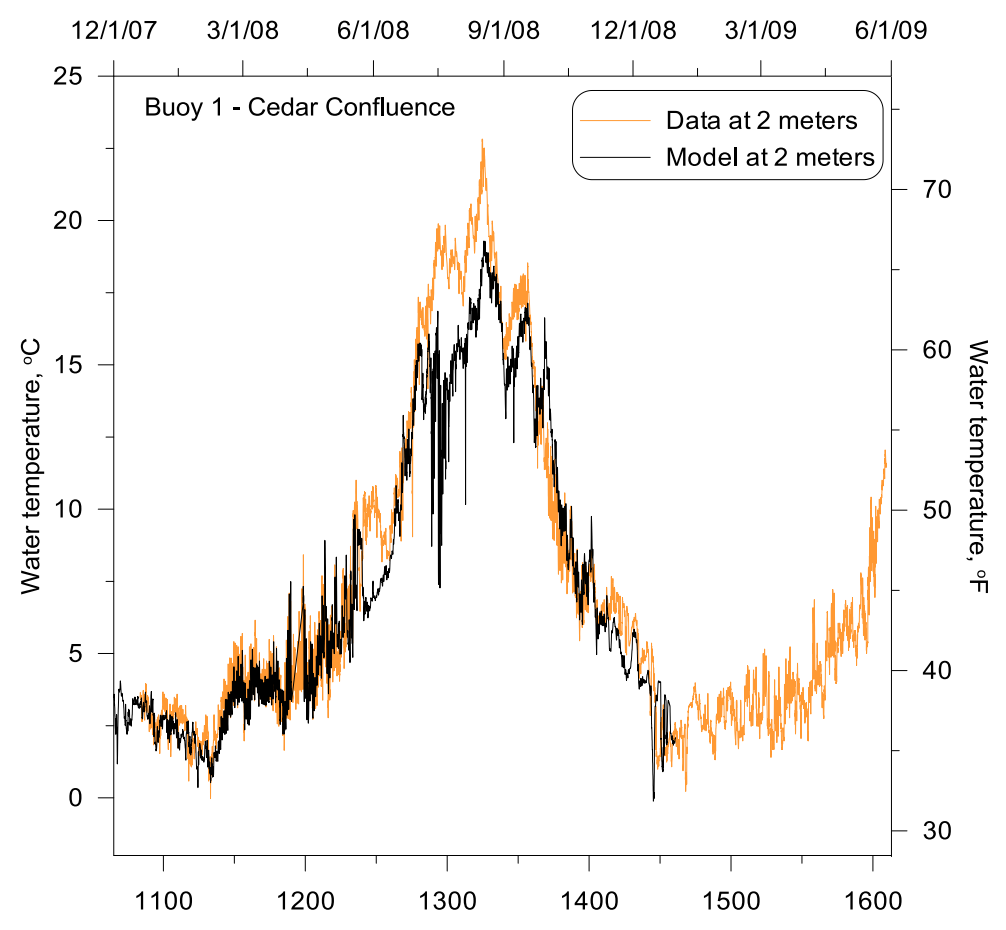

Figure 82. Model vs. data temperature comparison at Buoy 1 (corresponding to model segment 9) Cedar River Confluence - at 2 meter depth

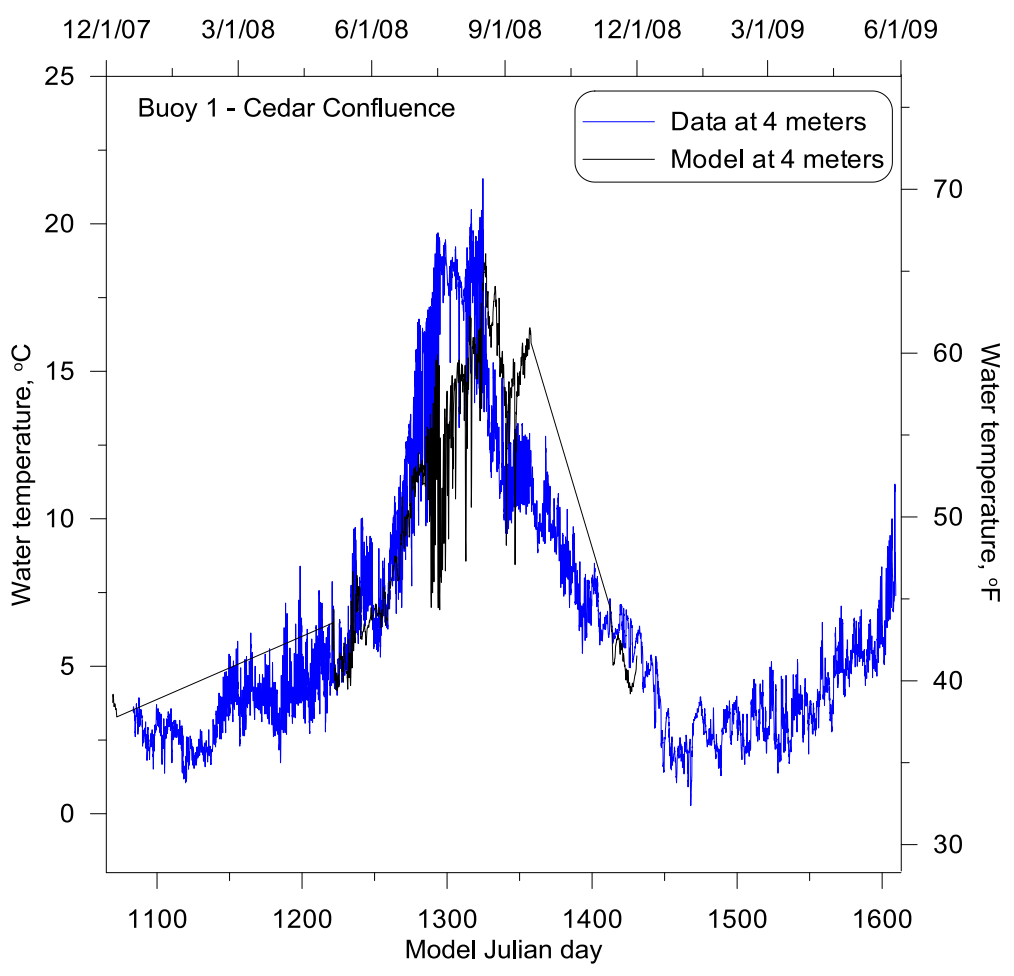

Figure 83. Model vs. data temperature comparison at Buoy 1 (corresponding to model segment 9) Cedar River Confluence - at 4 meter depth 


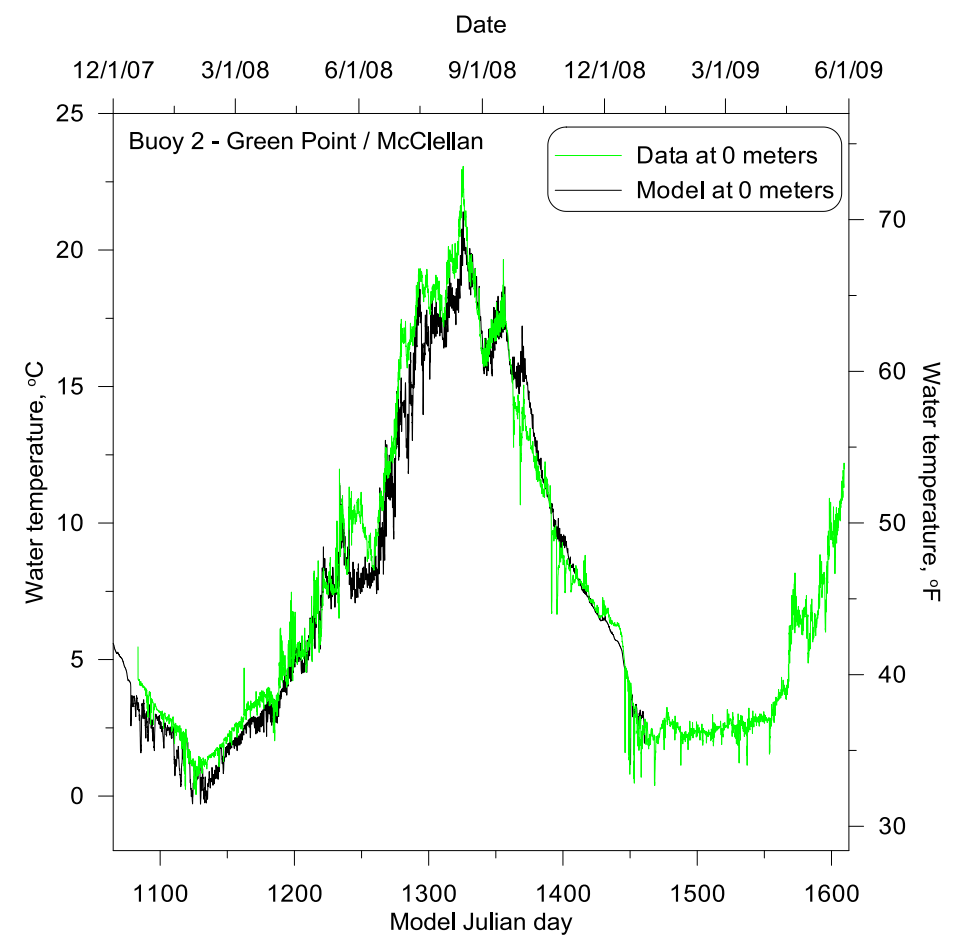

Figure 84. Model vs. data temperature comparison at Buoy 2 (corresponding to model segment 17) Green Point/McClellan - at water surface

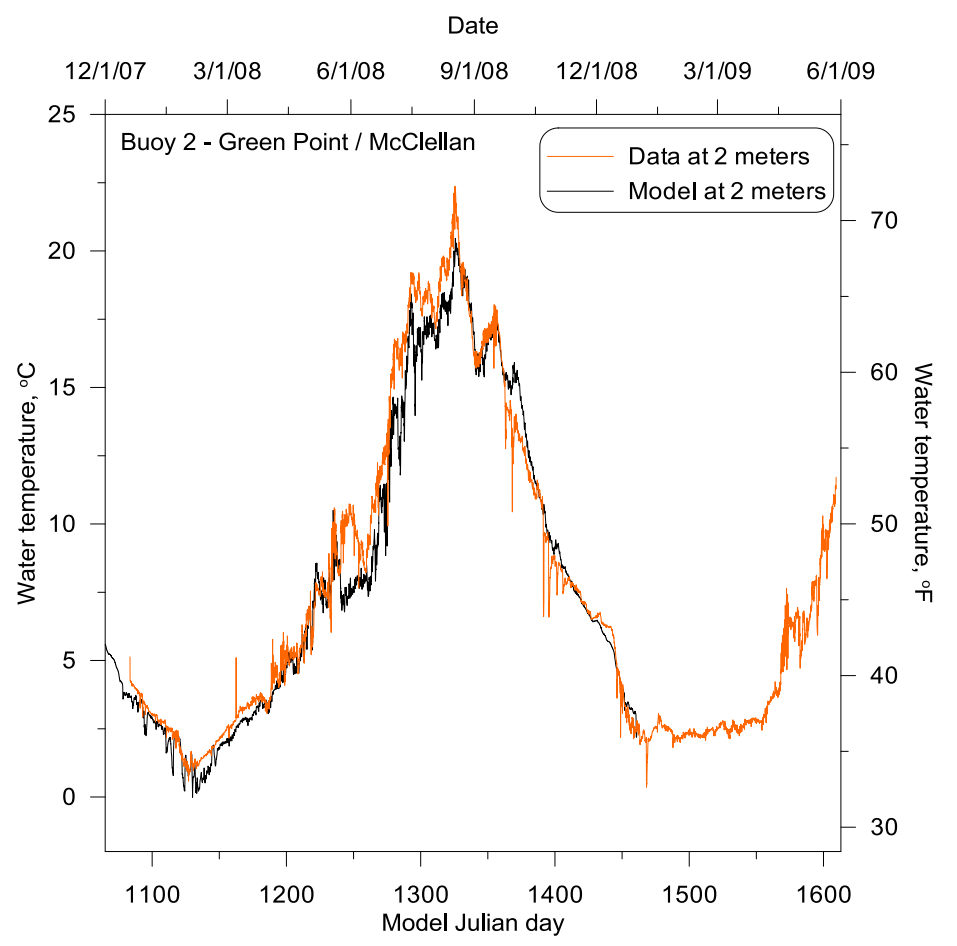

Figure 85. Model vs. data temperature comparison at Buoy 2 (corresponding to model segment 17) Green Point/McClellan - at 2 meter depth 


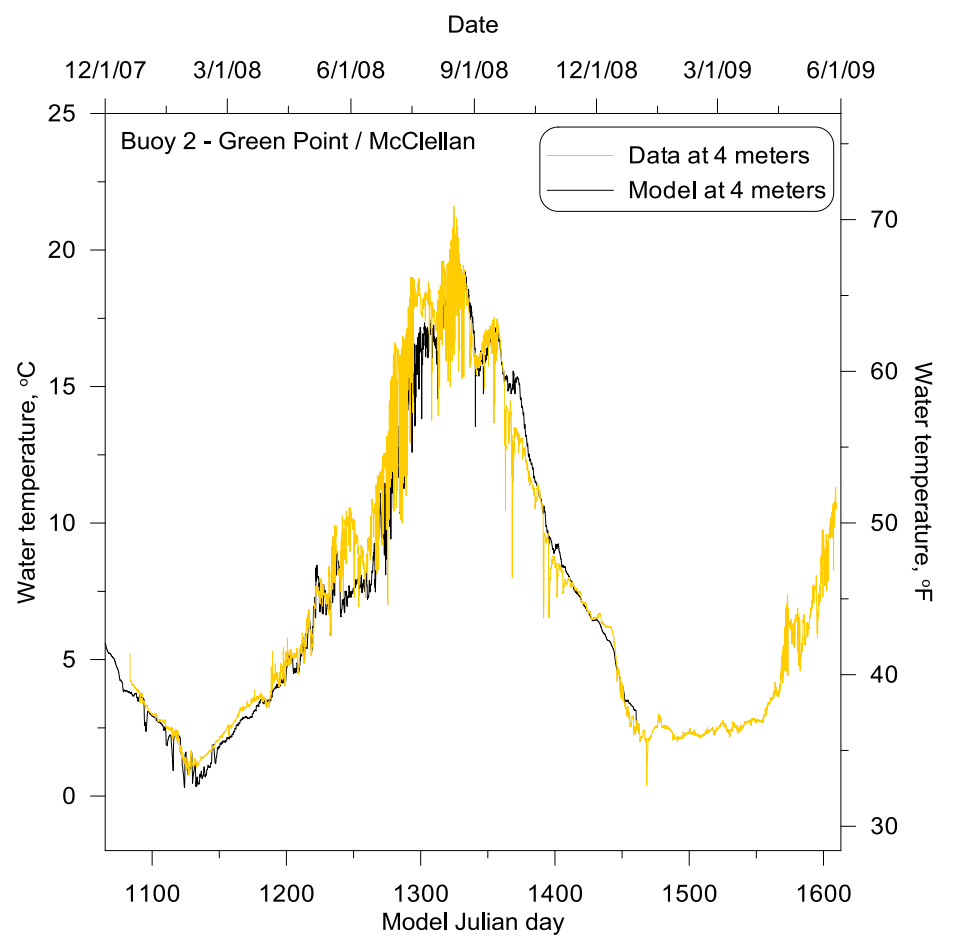

Figure 86. Model vs. data temperature comparison at Buoy 2 (corresponding to model segment 17) Green Point/McClellan - at 4 meter depth

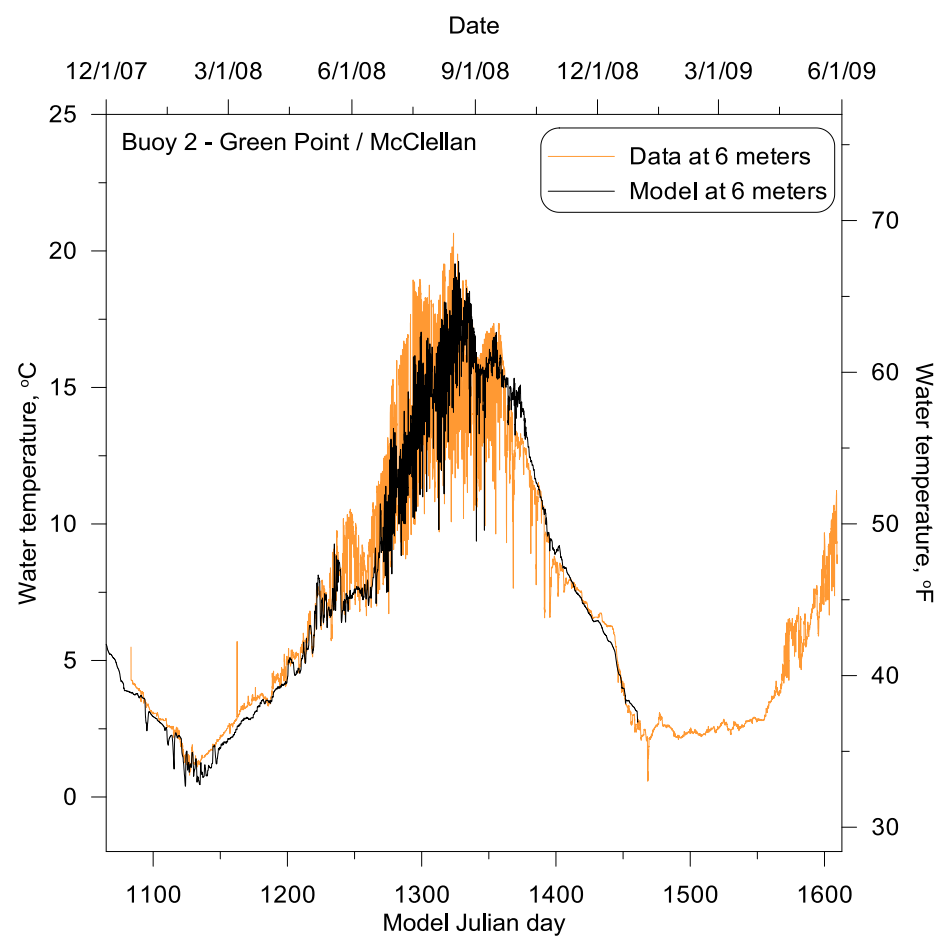

Figure 87. Model vs. data temperature comparison at Buoy 2 (corresponding to model segment 17) Green Point/McClellan - at 6 meter depth 


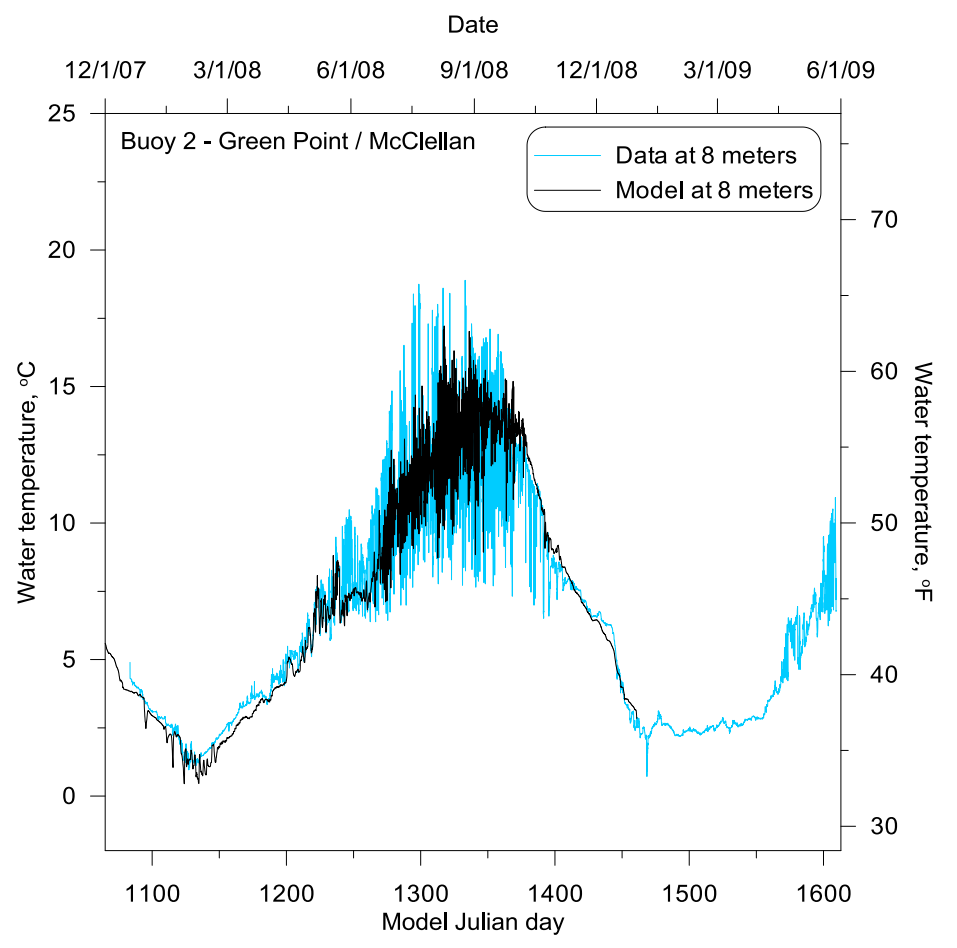

Figure 88. Model vs. data temperature comparison at Buoy 2 (corresponding to model segment 17) Green Point/McClellan - at 8 meter depth

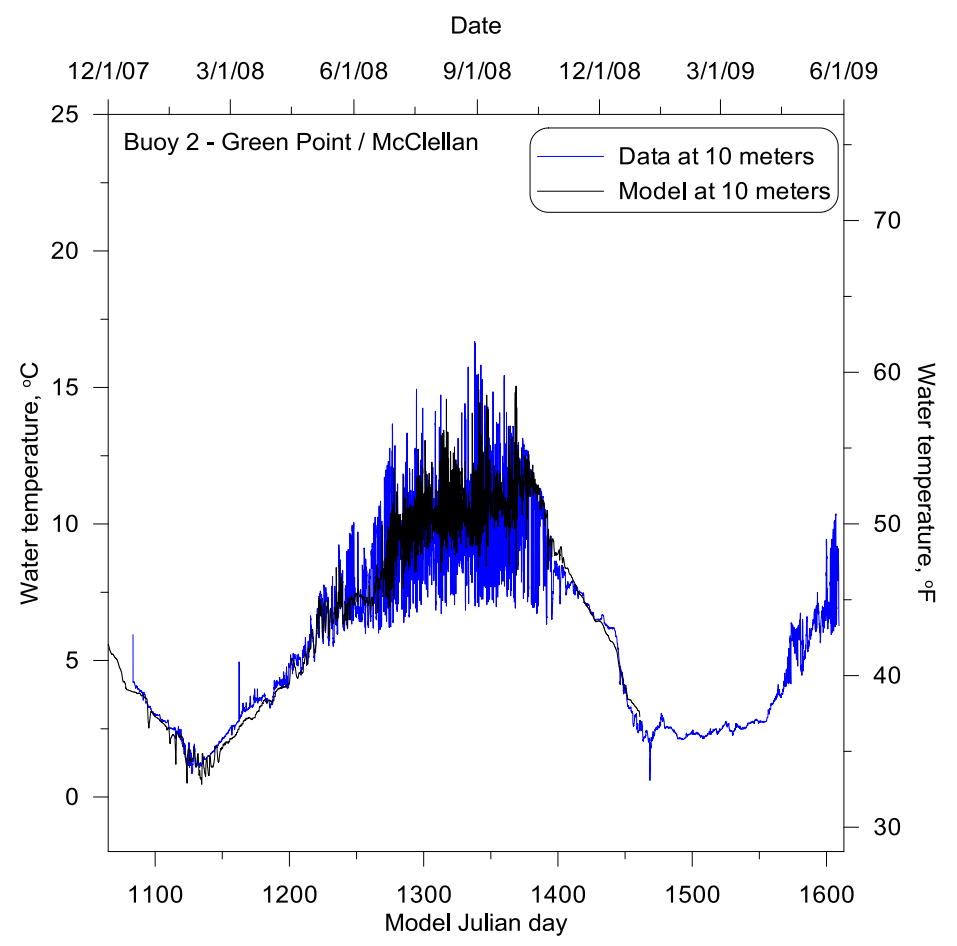

Figure 89. Model vs. data temperature comparison at Buoy 2 (corresponding to model segment 17) Green Point/McClellan - at 10 meter depth 


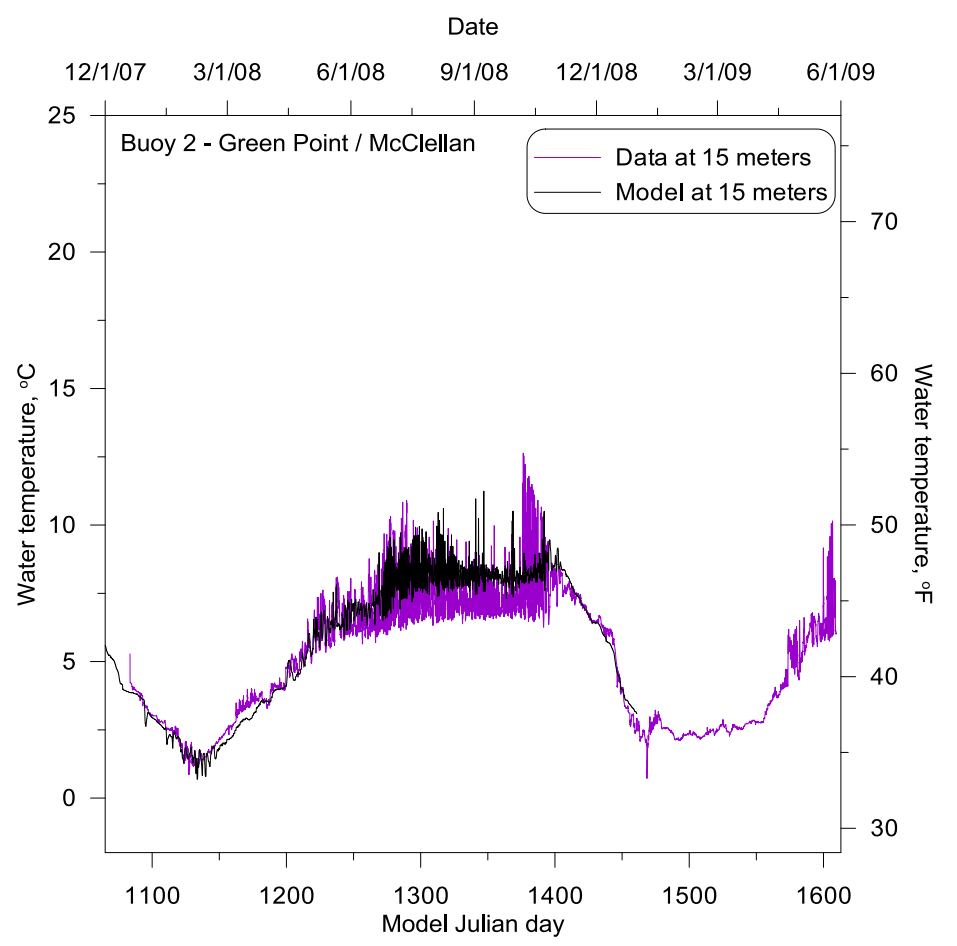

Figure 90. Model vs. data temperature comparison at Buoy 2 (corresponding to model segment 17) Green Point/McClellan - at 15 meter depth

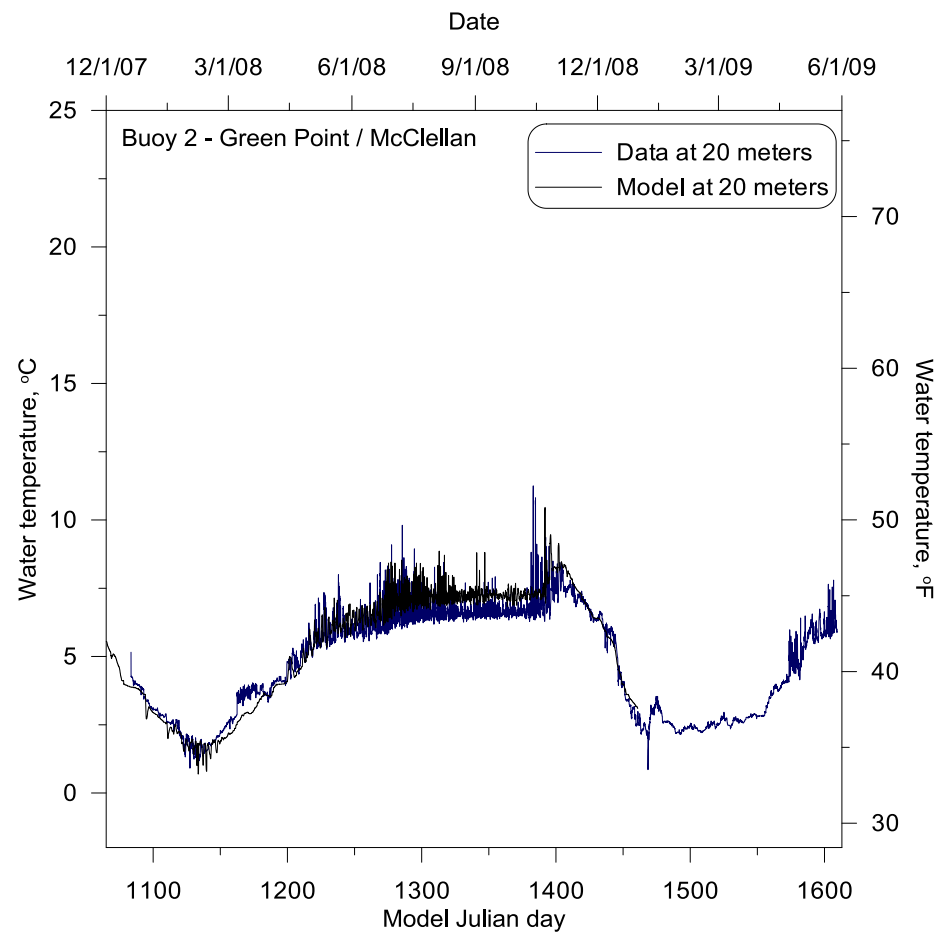

Figure 91. Model vs. data temperature comparison at Buoy 2 (corresponding to model segment 17) Green Point/McClellan - at 20 meter depth 


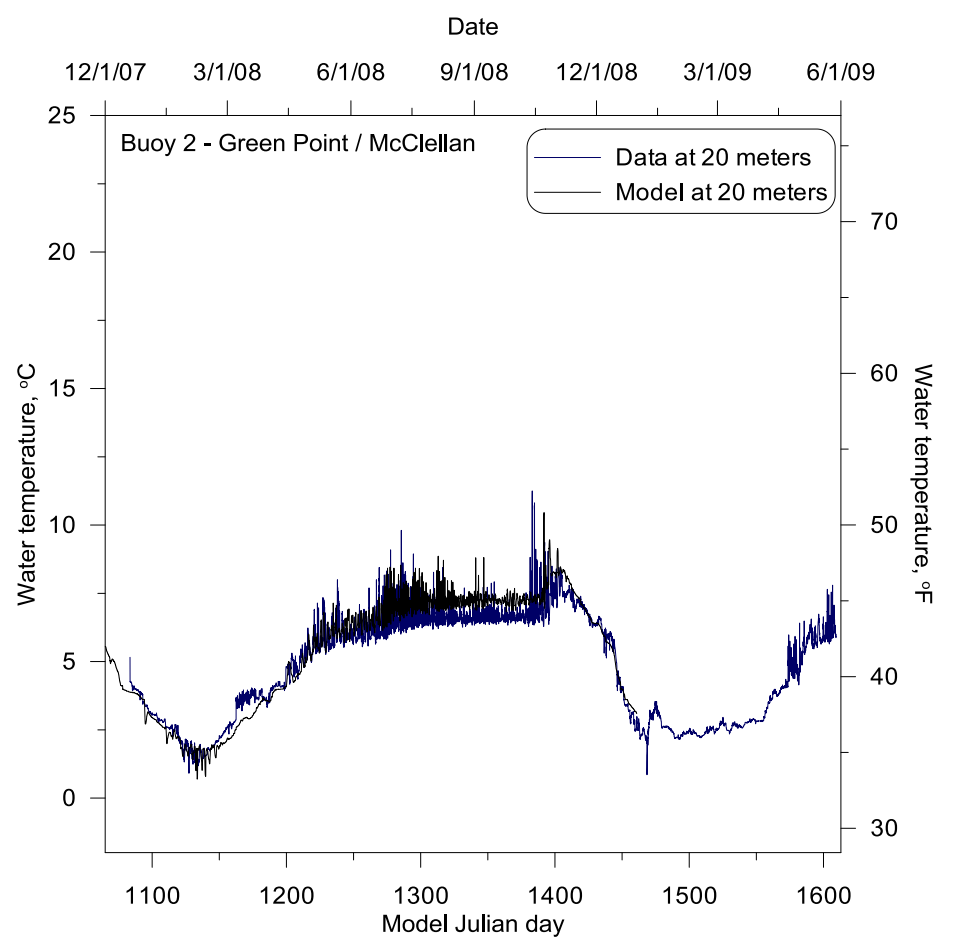

Figure 92. Model vs. data temperature comparison at Buoy 2 (corresponding to model segment 17) Green Point/McClellan - at 20 meter depth

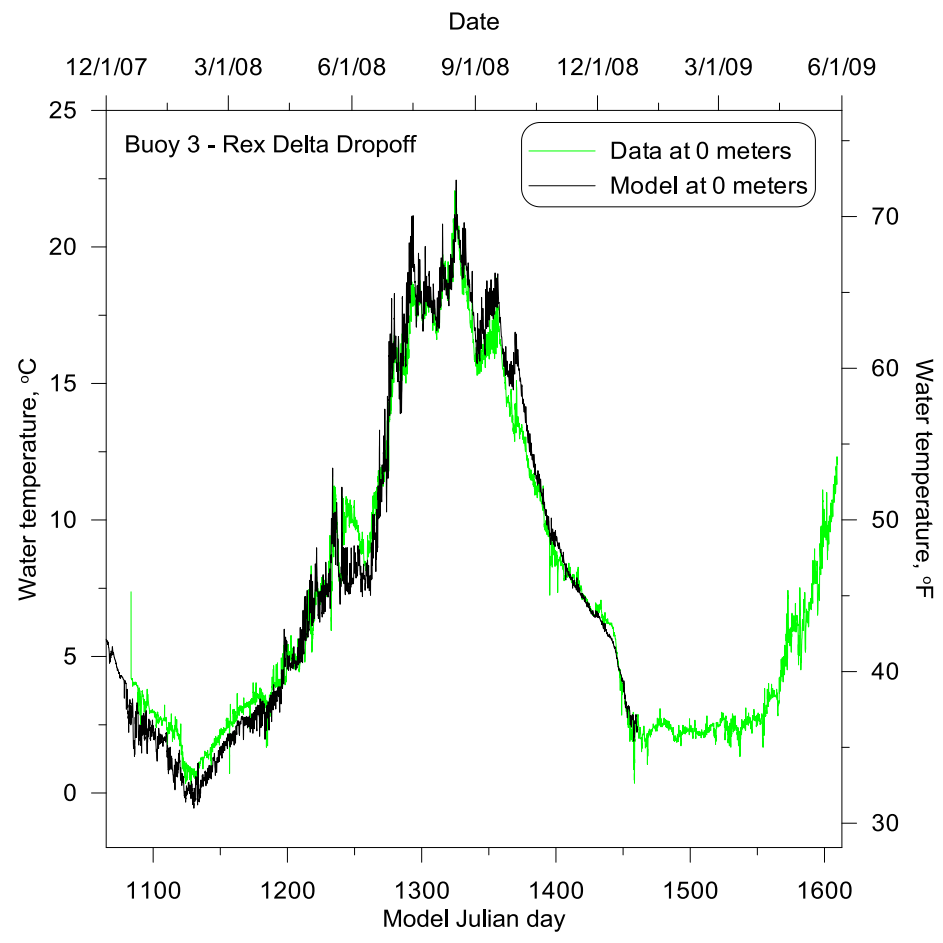

Figure 93. Model vs. data temperature comparison at Buoy 3 (corresponding to model segment 47) Rex Delta Drop-off - at water surface 


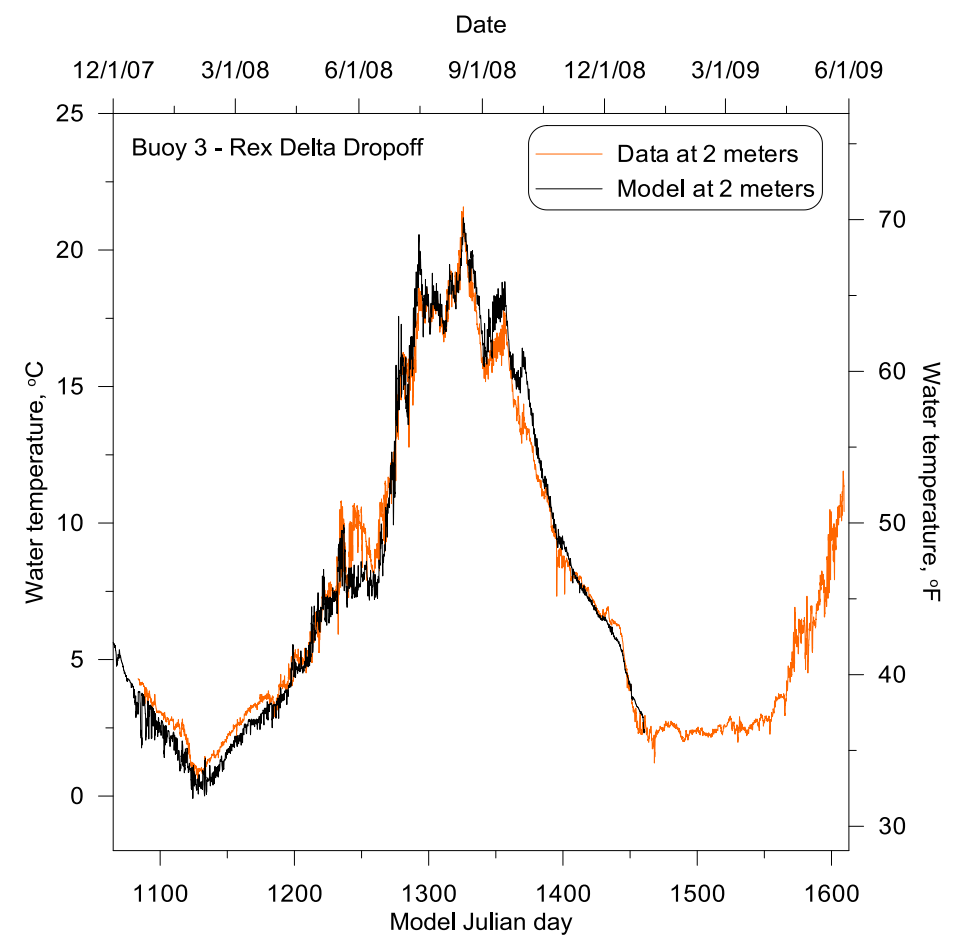

Figure 94. Model vs. data temperature comparison at Buoy 3 (corresponding to model segment 47) Rex Delta Drop-off - at 2 meter depth

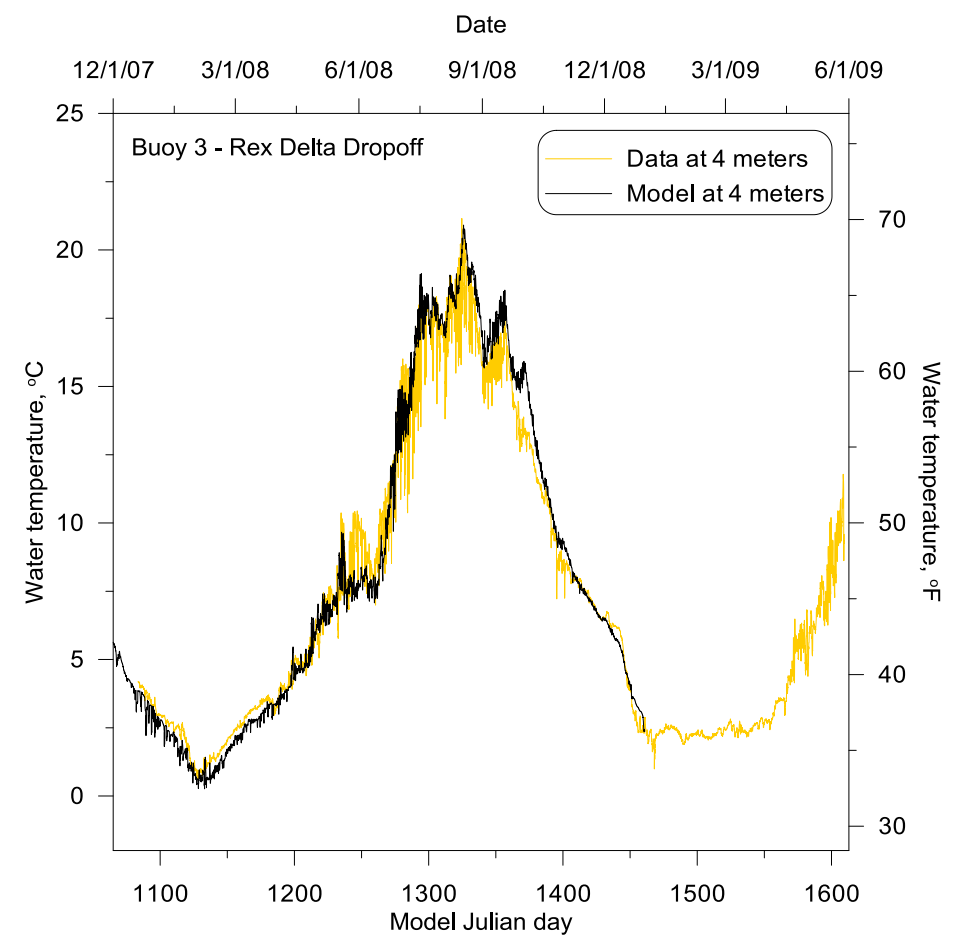

Figure 95. Model vs. data temperature comparison at Buoy 3 (corresponding to model segment 47) Rex Delta Drop-off - at 4 meter depth 


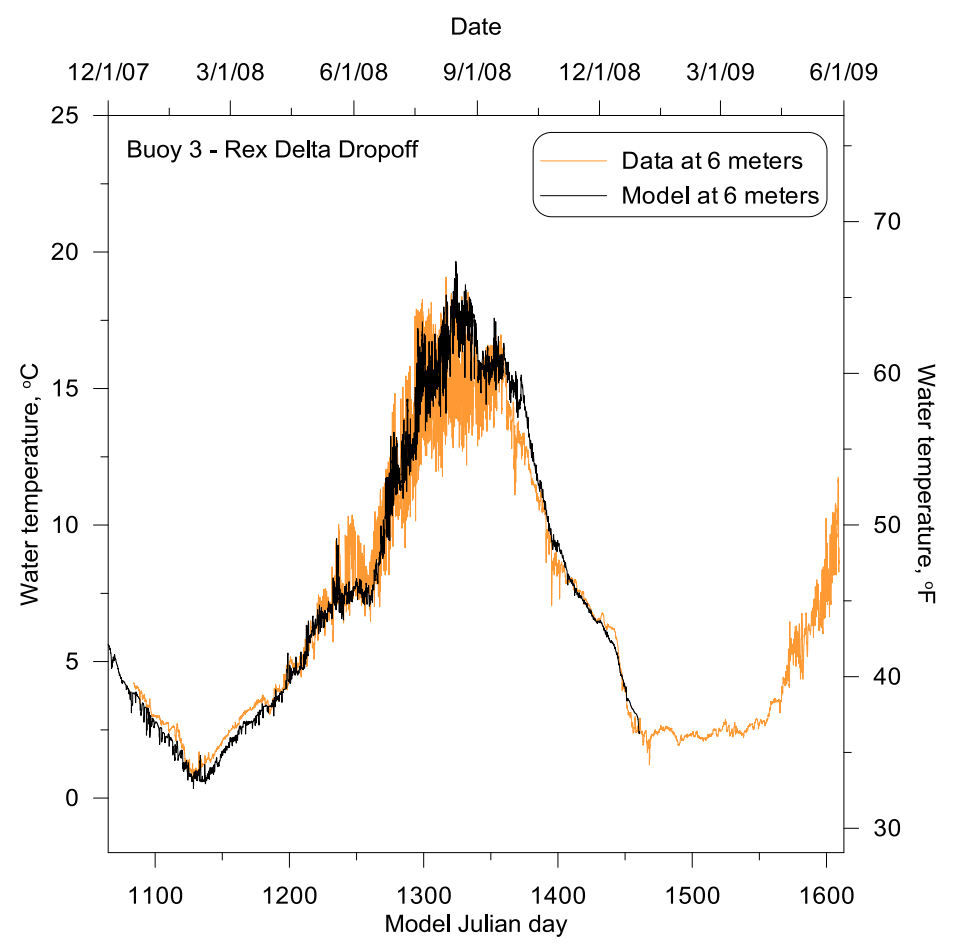

Figure 96. Model vs. data temperature comparison at Buoy 3 (corresponding to model segment 47) Rex Delta Drop-off - at 6 meter depth

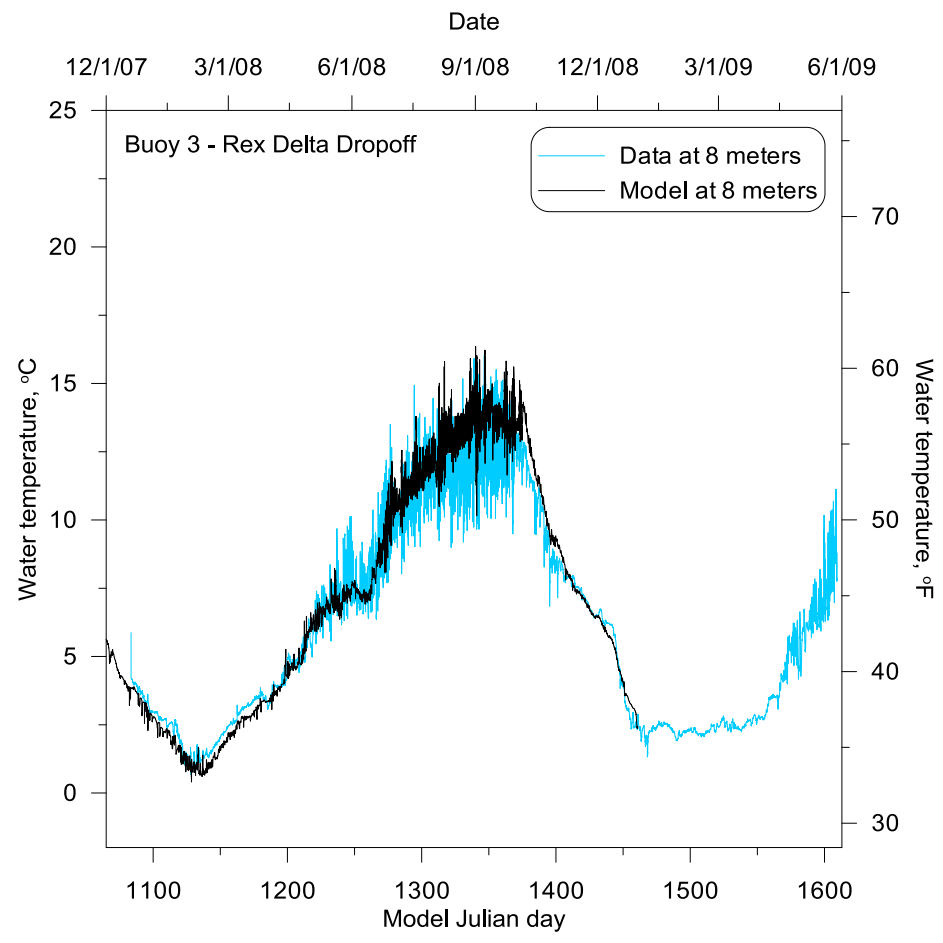

Figure 97. Model vs. data temperature comparison at Buoy 3 (corresponding to model segment 47) Rex Delta Drop-off - at 8 meter depth 


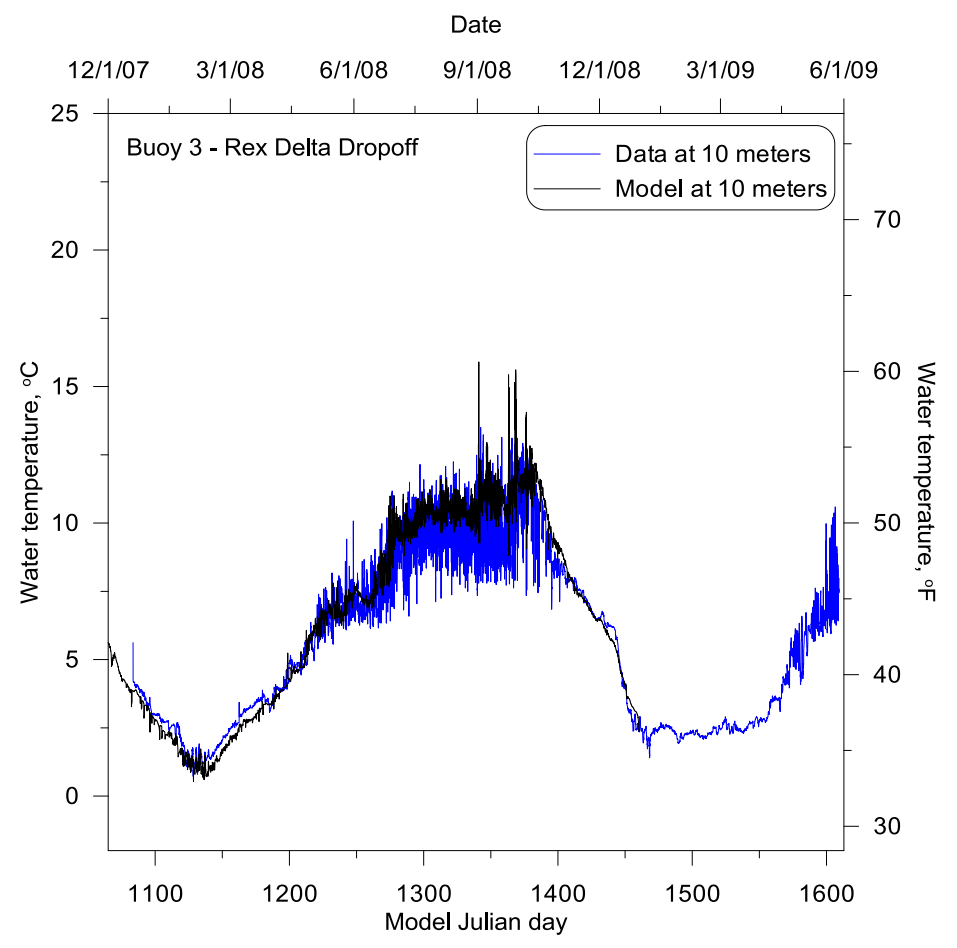

Figure 98. Model vs. data temperature comparison at Buoy 3 (corresponding to model segment 47) Rex Delta Drop-off - at 10 meter depth

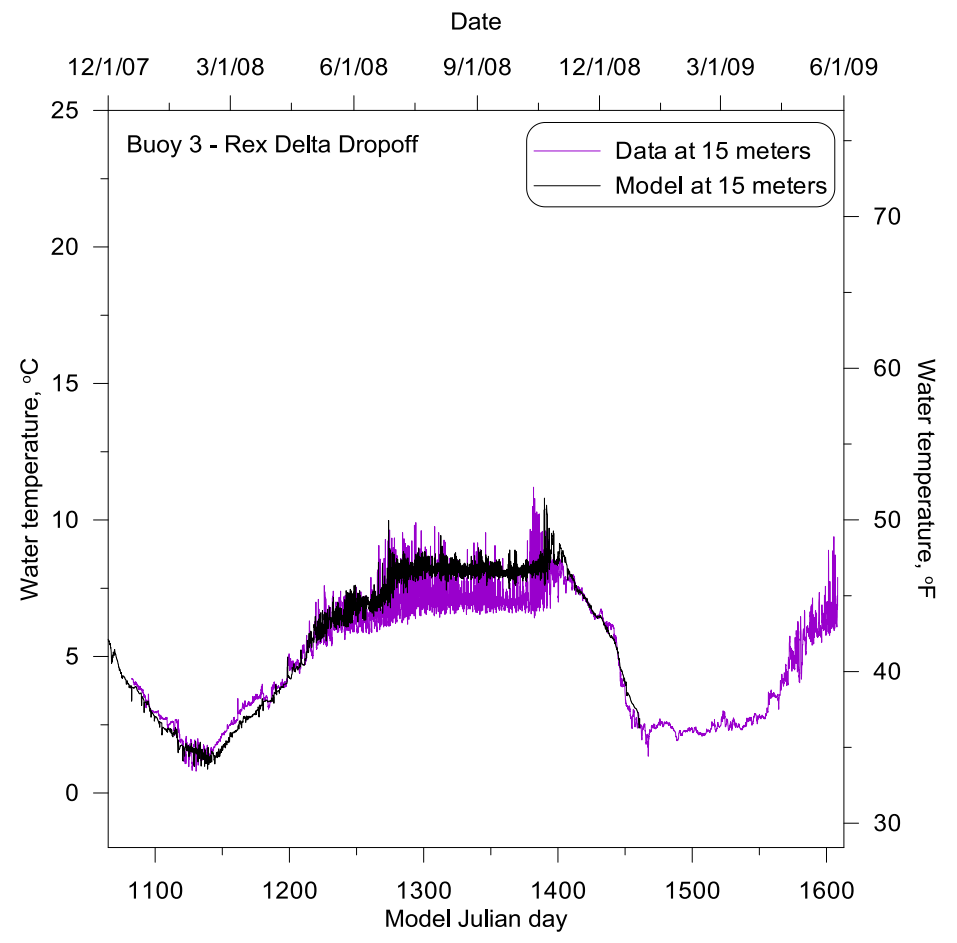

Figure 99. Model vs. data temperature comparison at Buoy 3 (corresponding to model segment 47) Rex Delta Drop-off - at 15 meter depth 


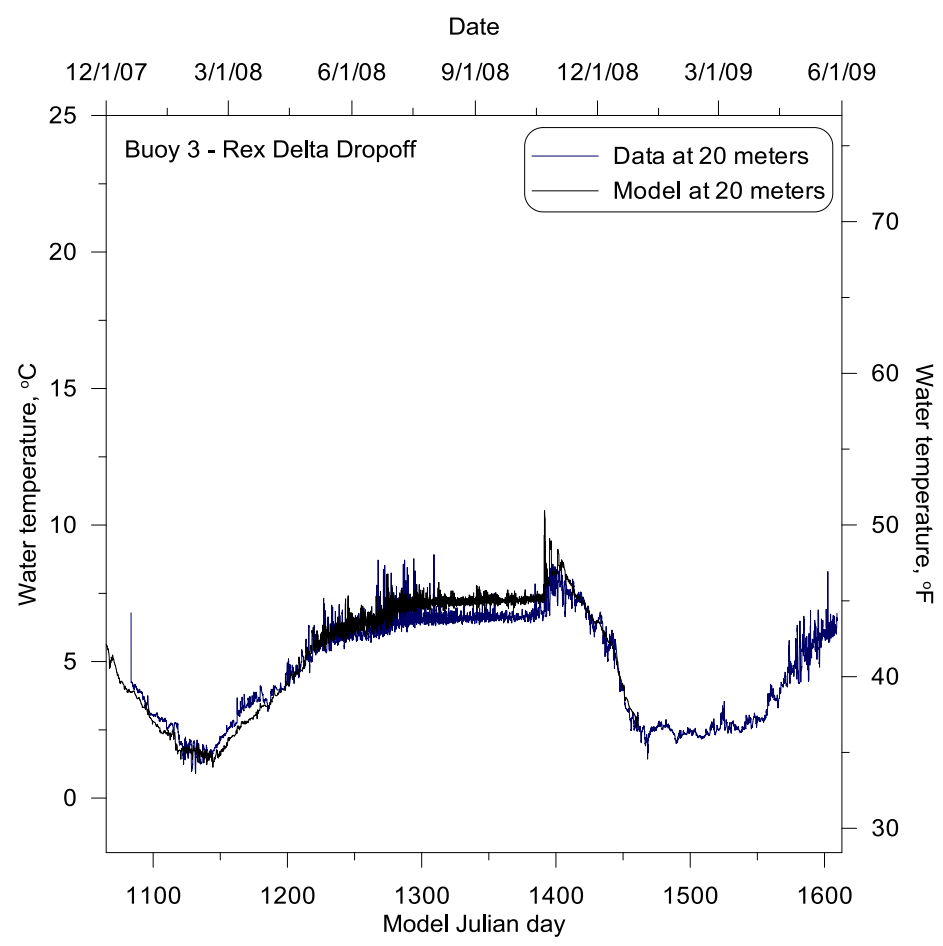

Figure 100. Model vs. data temperature comparison at Buoy 3 (corresponding to model segment 47) Rex Delta Drop-off - at 20 meter depth

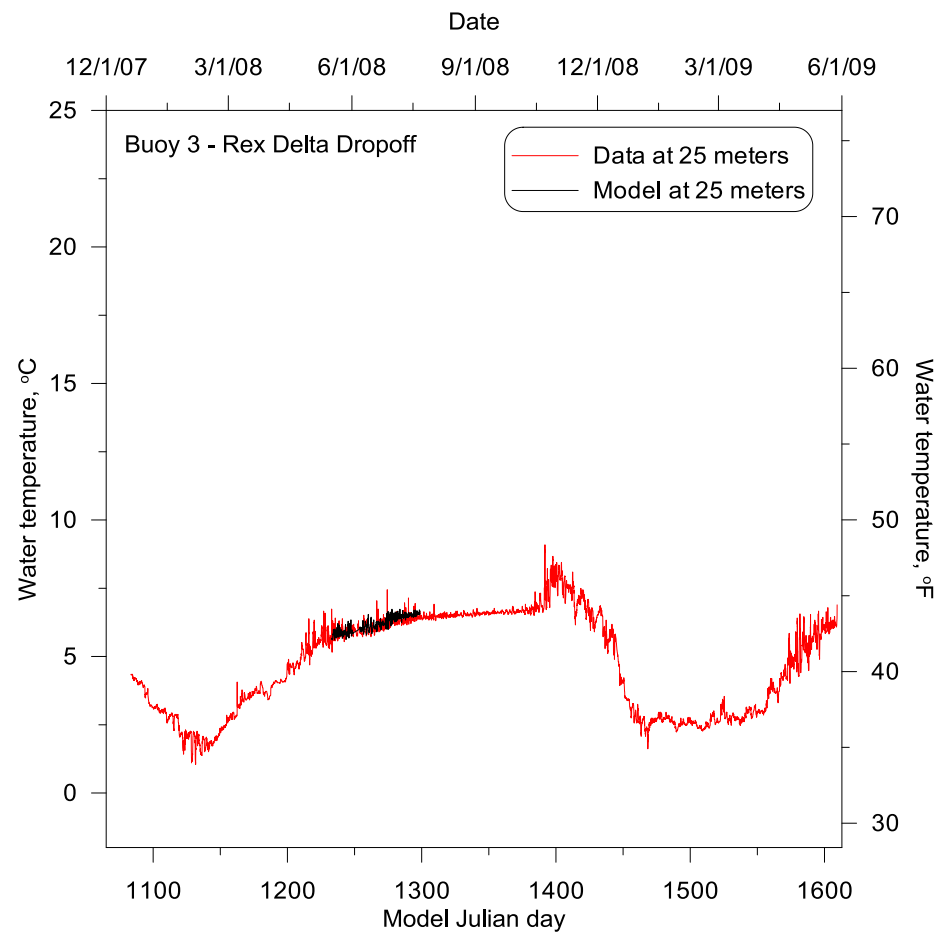

Figure 101. Model vs. data temperature comparison at Buoy 3 (corresponding to model segment 47) Rex Delta Drop-off - at 25 meter depth 


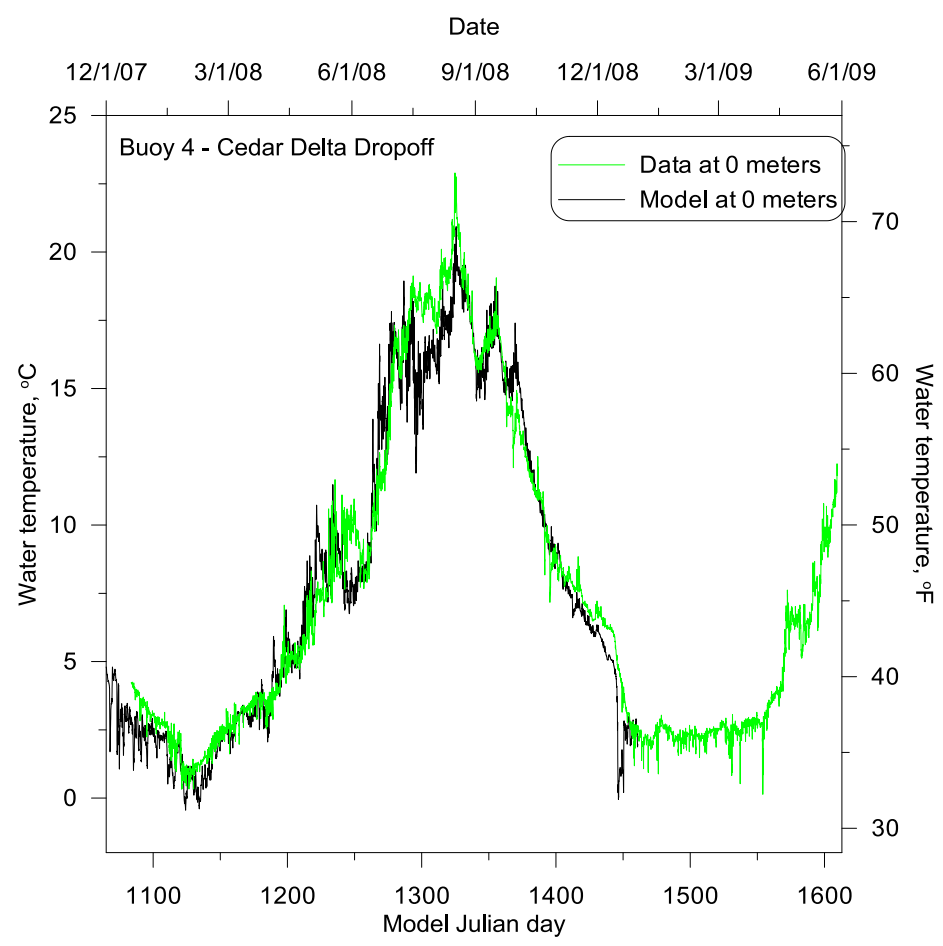

Figure 102. Model vs. data temperature comparison at Buoy 4 (corresponding to model segment 13) Cedar Delta Drop-off - at water surface

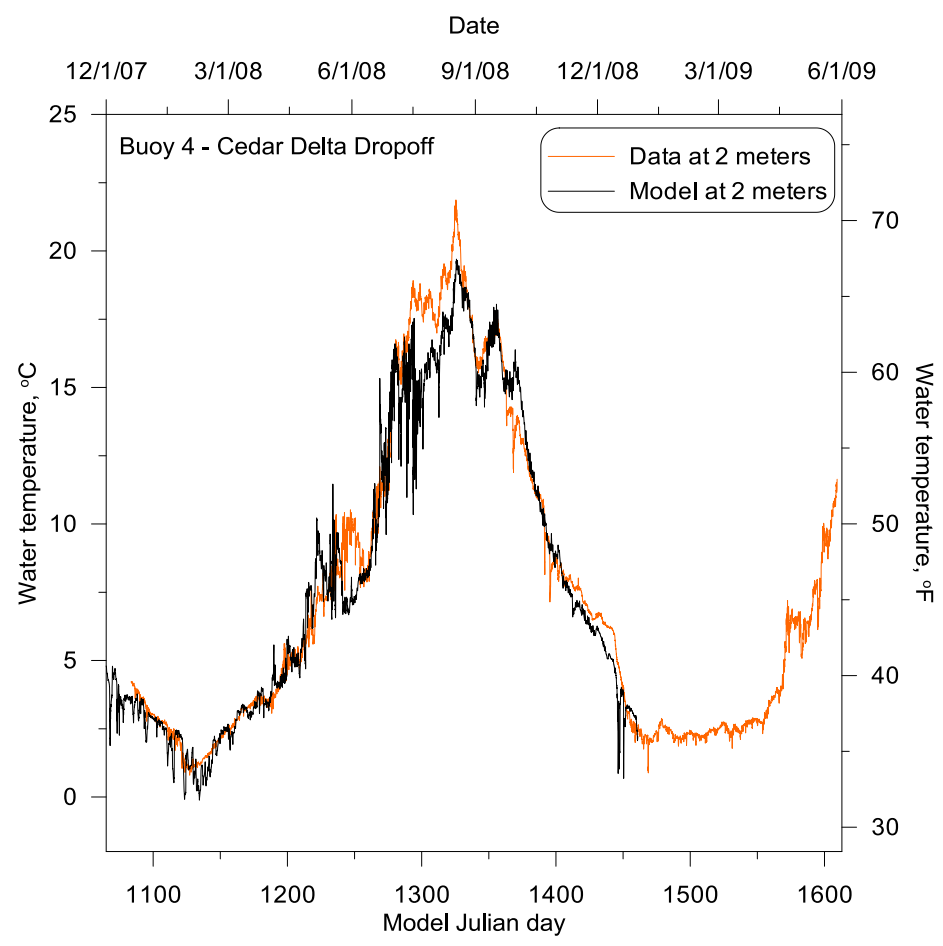

Figure 103. Model vs. data temperature comparison at Buoy 4 (corresponding to model segment 13) Cedar Delta Drop-off - at 2 meter depth 


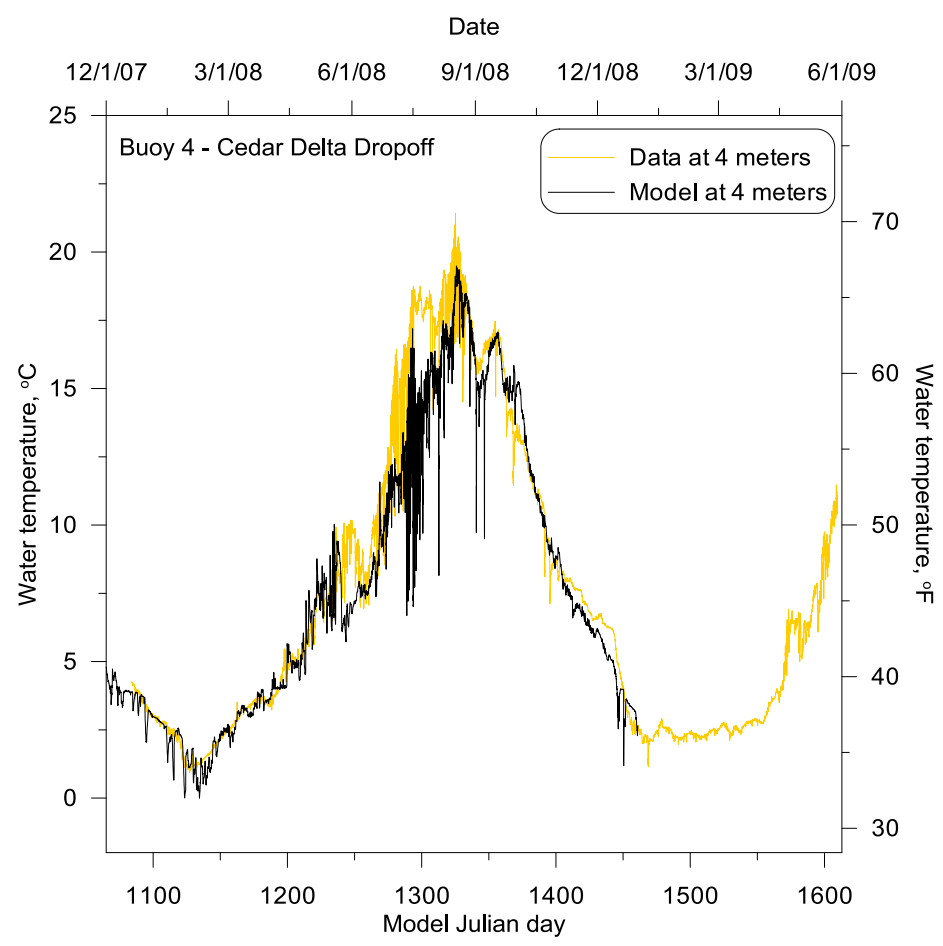

Figure 104. Model vs. data temperature comparison at Buoy 4 (corresponding to model segment 13) Cedar Delta Drop-off - at 4 meter depth

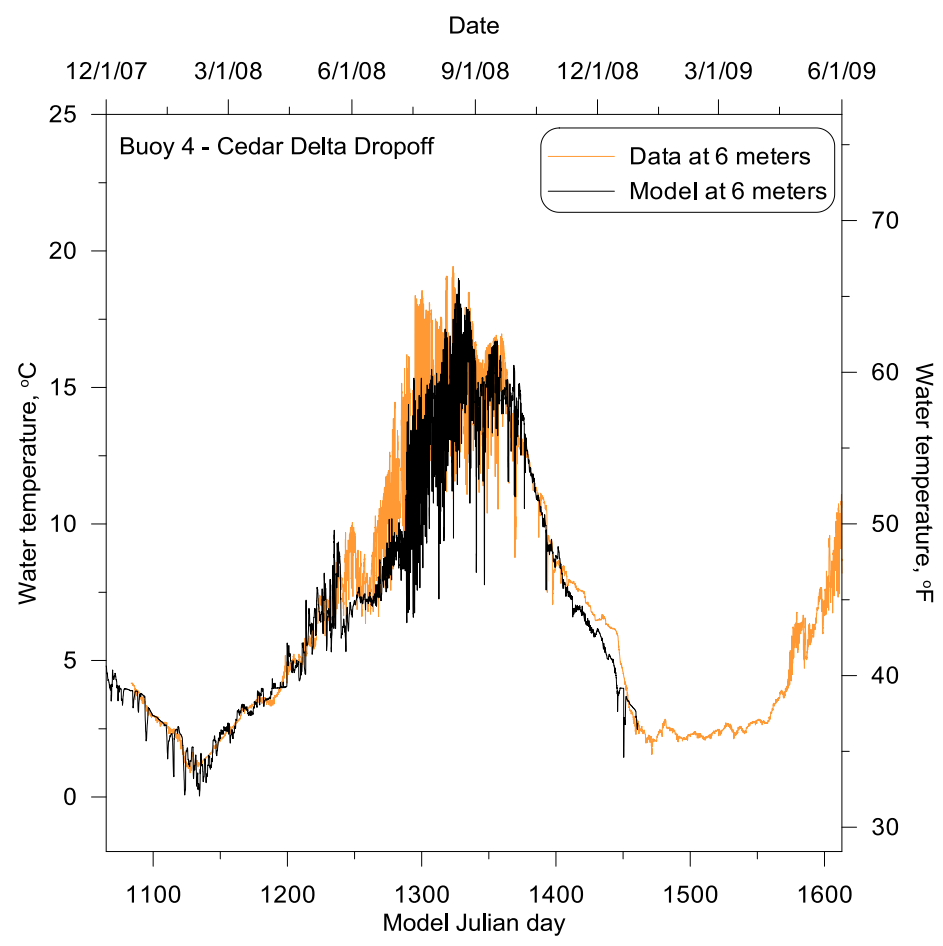

Figure 105. Model vs. data temperature comparison at Buoy 4 (corresponding to model segment 13) Cedar Delta Drop-off - at 6 meter depth 


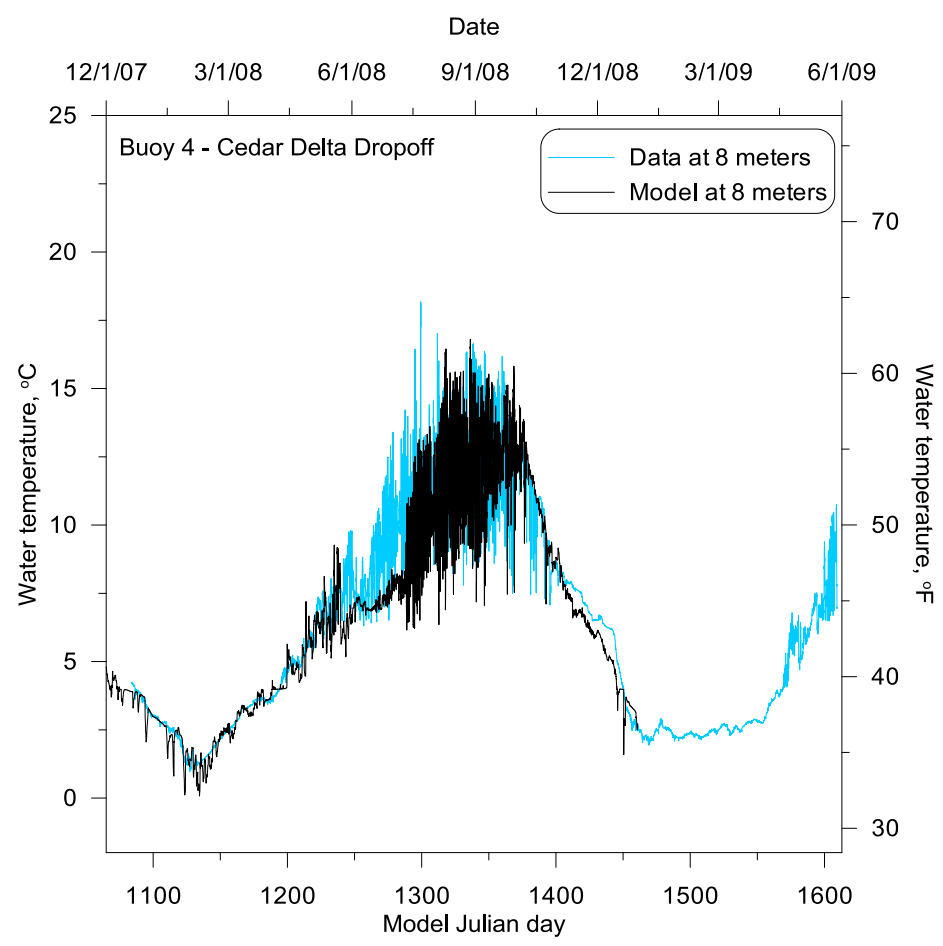

Figure 106. Model vs. data temperature comparison at Buoy 4 (corresponding to model segment 13) Cedar Delta Drop-off - at 8 meter depth

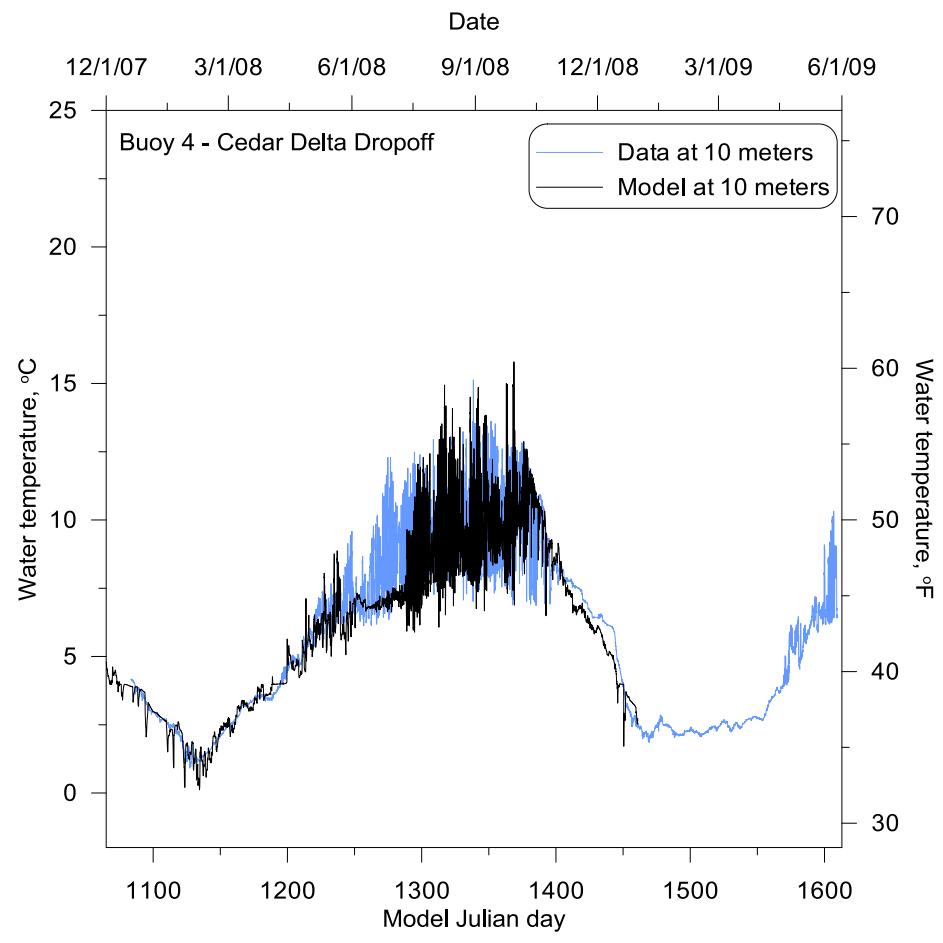

Figure 107. Model vs. data temperature comparison at Buoy 4 (corresponding to model segment 13) Cedar Delta Drop-off - at 10 meter depth 


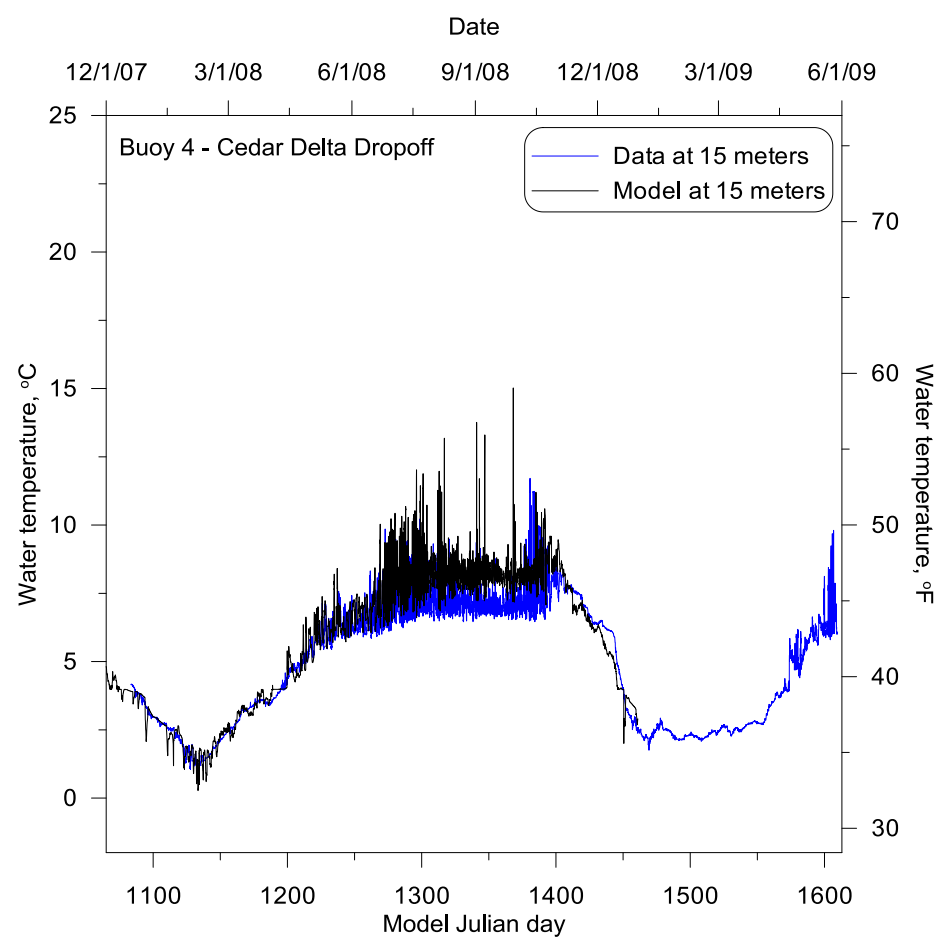

Figure 108. Model vs. data temperature comparison at Buoy 4 (corresponding to model segment 13) Cedar Delta Drop-off - at 15 meter depth

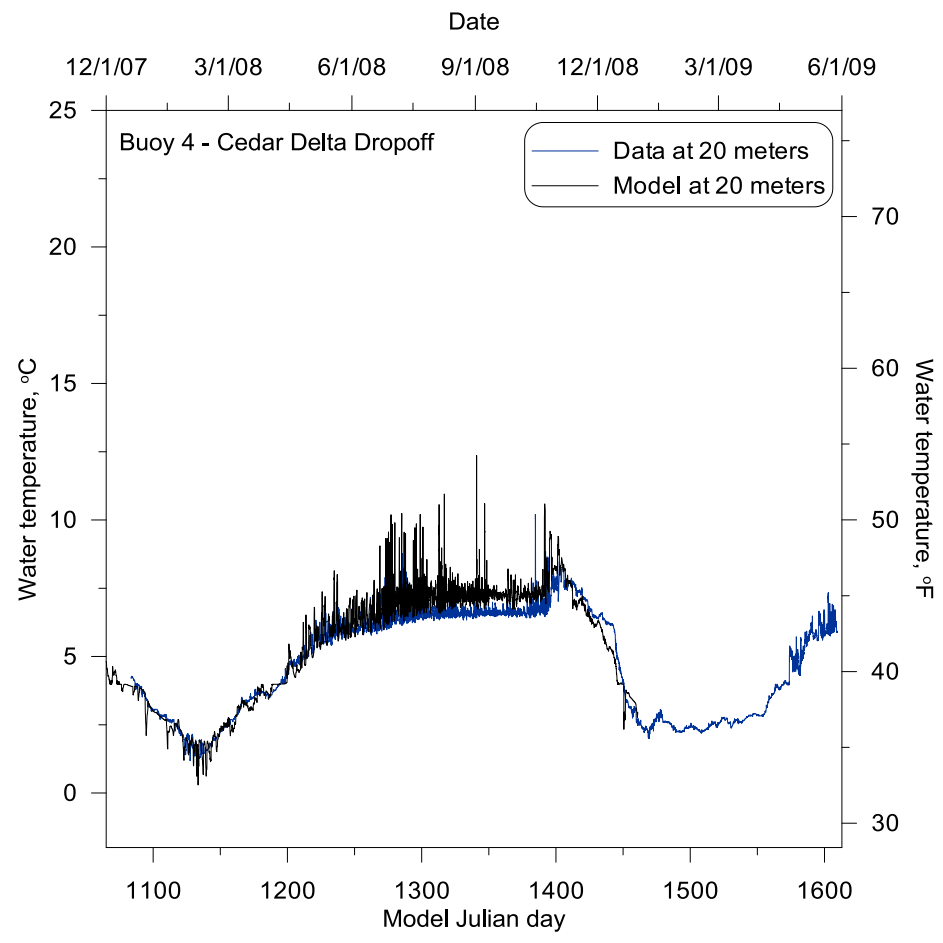

Figure 109. Model vs. data temperature comparison at Buoy 4 (corresponding to model segment 13) Cedar Delta Drop-off - at 20 meter depth 


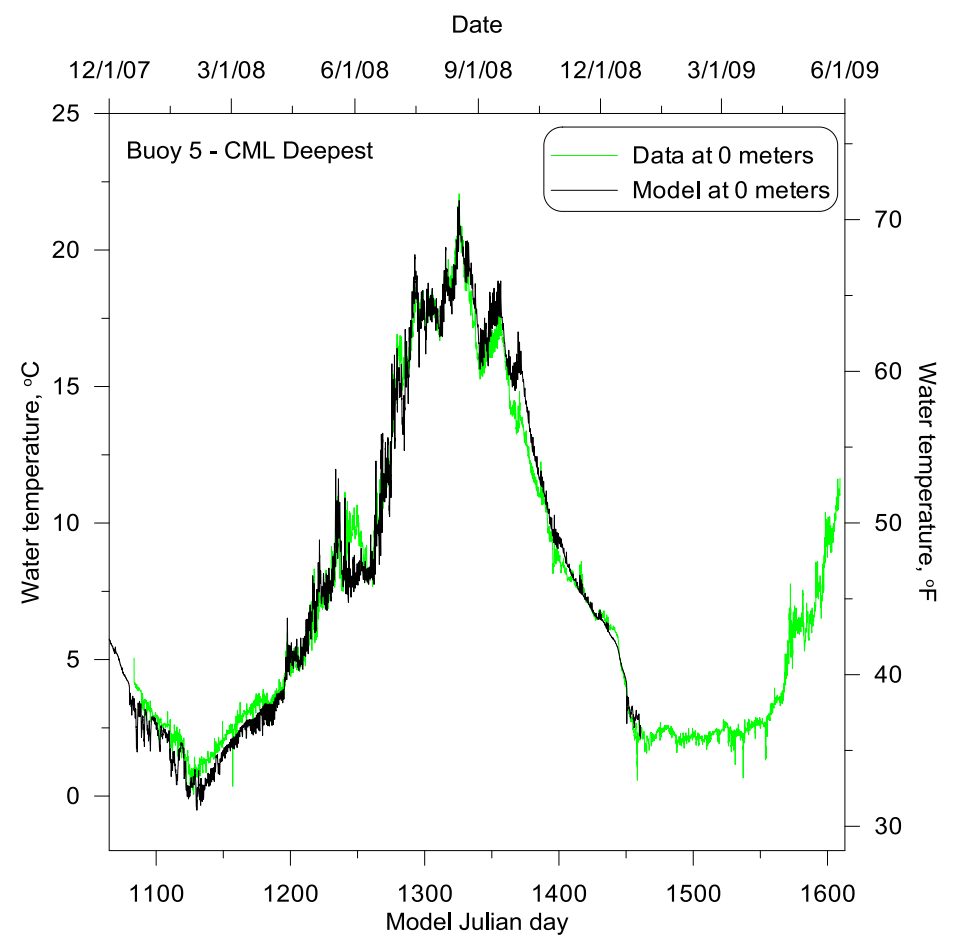

Figure 110. Model vs. data temperature comparison at Buoy 5 (corresponding to model segment 23) CML Deepest - at water surface

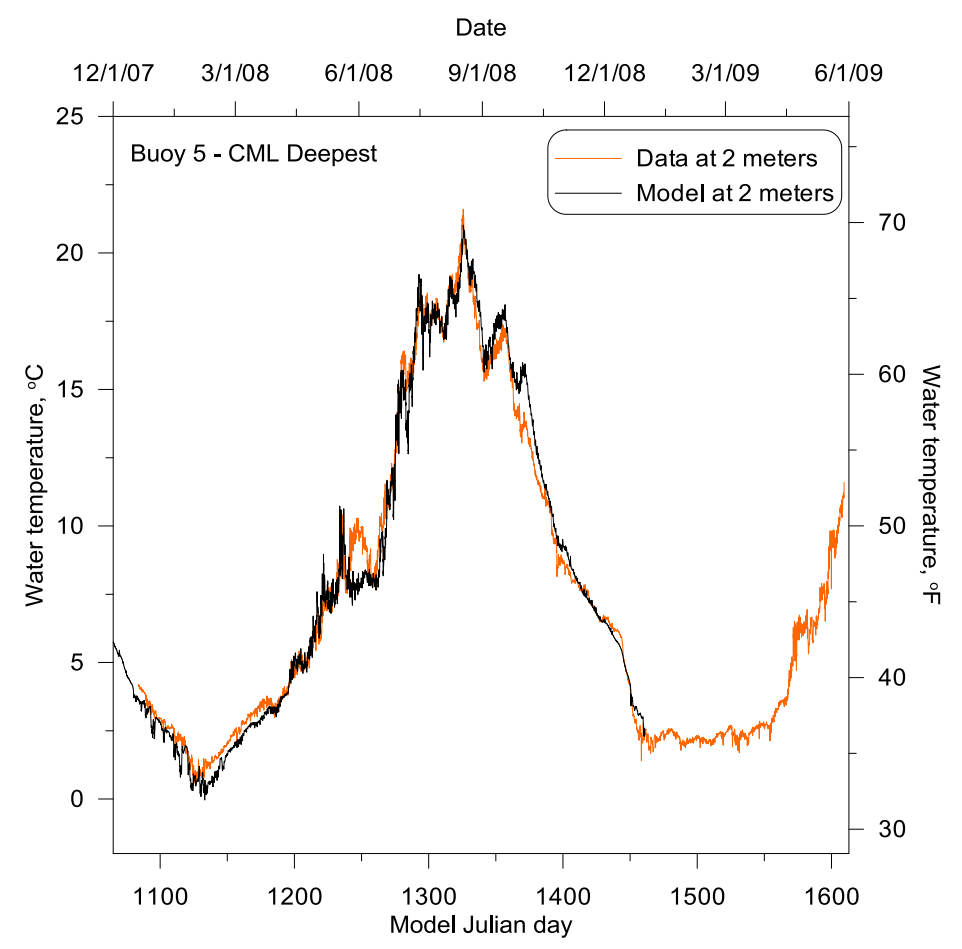

Figure 111. Model vs. data temperature comparison at Buoy 5 (corresponding to model segment 23) CML Deepest - at 2 meters 


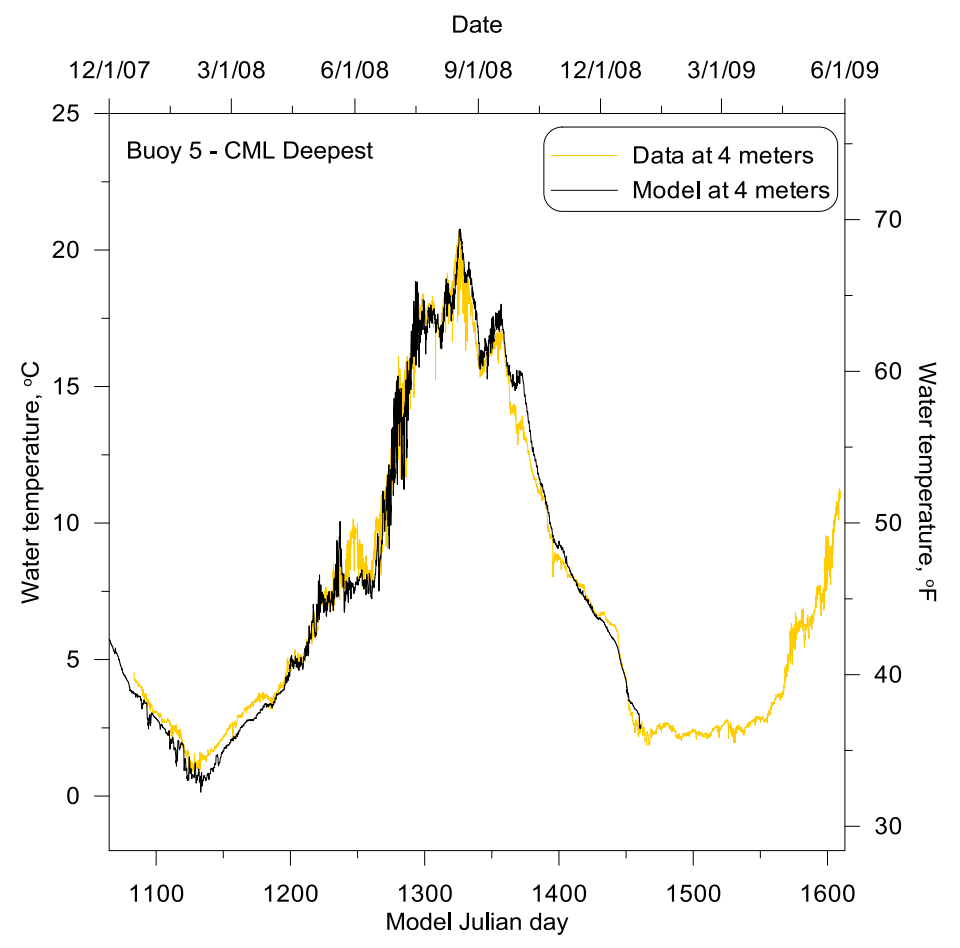

Figure 112. Model vs. data temperature comparison at Buoy 5 (corresponding to model segment 23) CML Deepest - at 4 meters

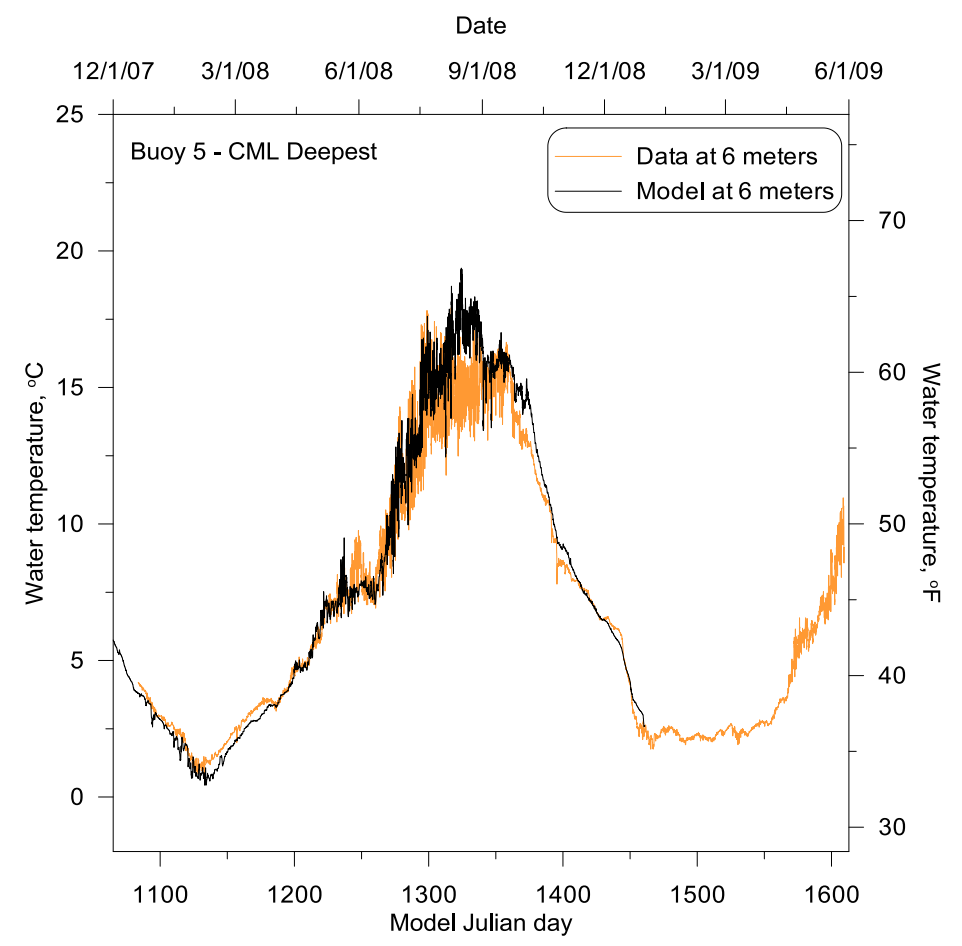

Figure 113. Model vs. data temperature comparison at Buoy 5 (corresponding to model segment 23) CML Deepest - at 6 meters 


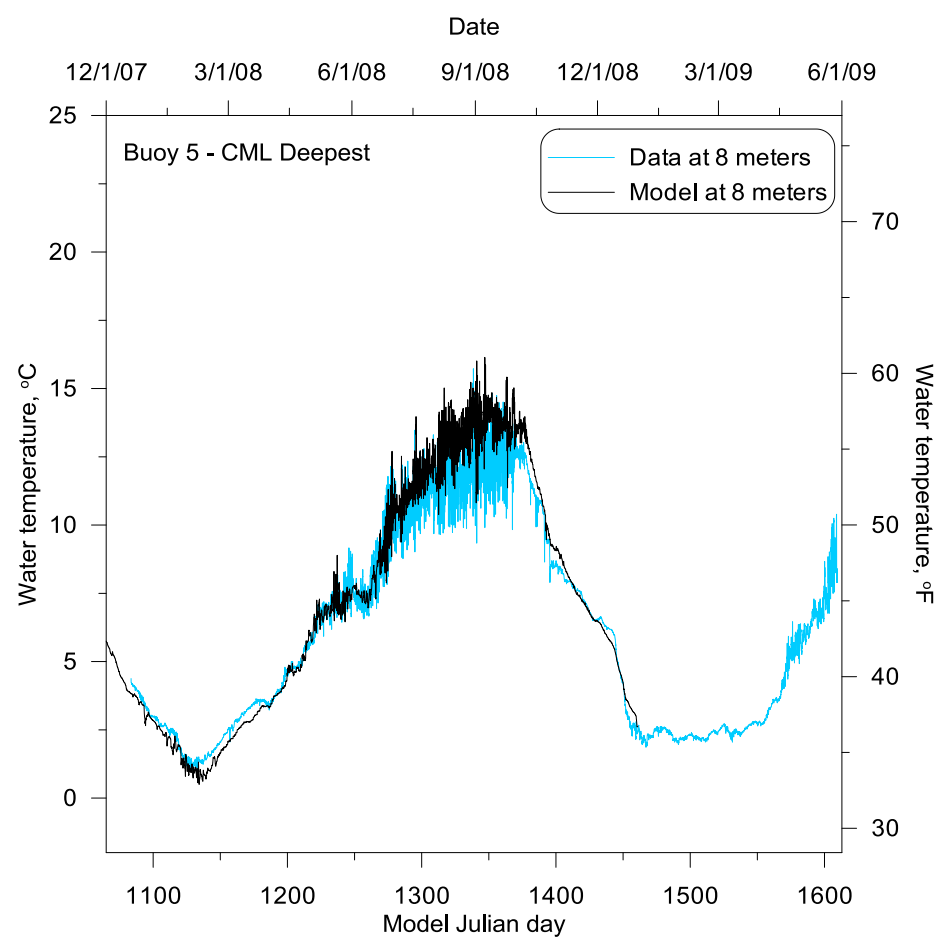

Figure 114. Model vs. data temperature comparison at Buoy 5 (corresponding to model segment 23) CML Deepest - at 8 meters

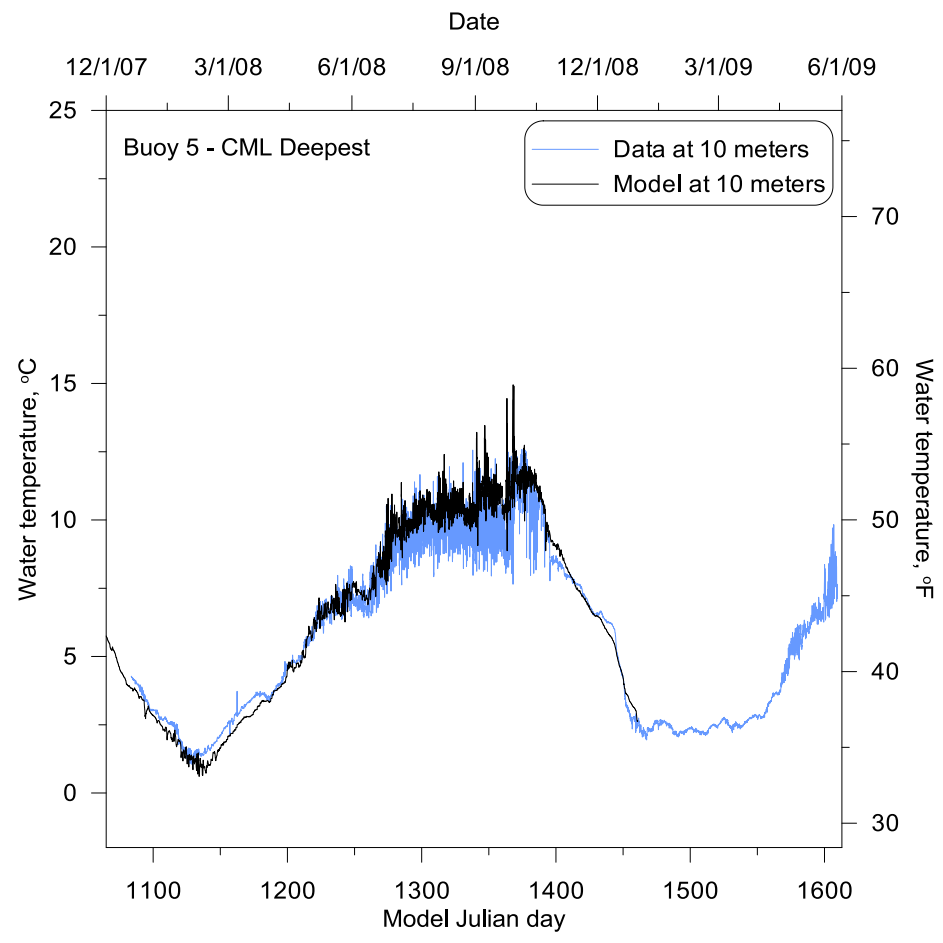

Figure 115. Model vs. data temperature comparison at Buoy 5 (corresponding to model segment 23) CML Deepest - at 10 meters 


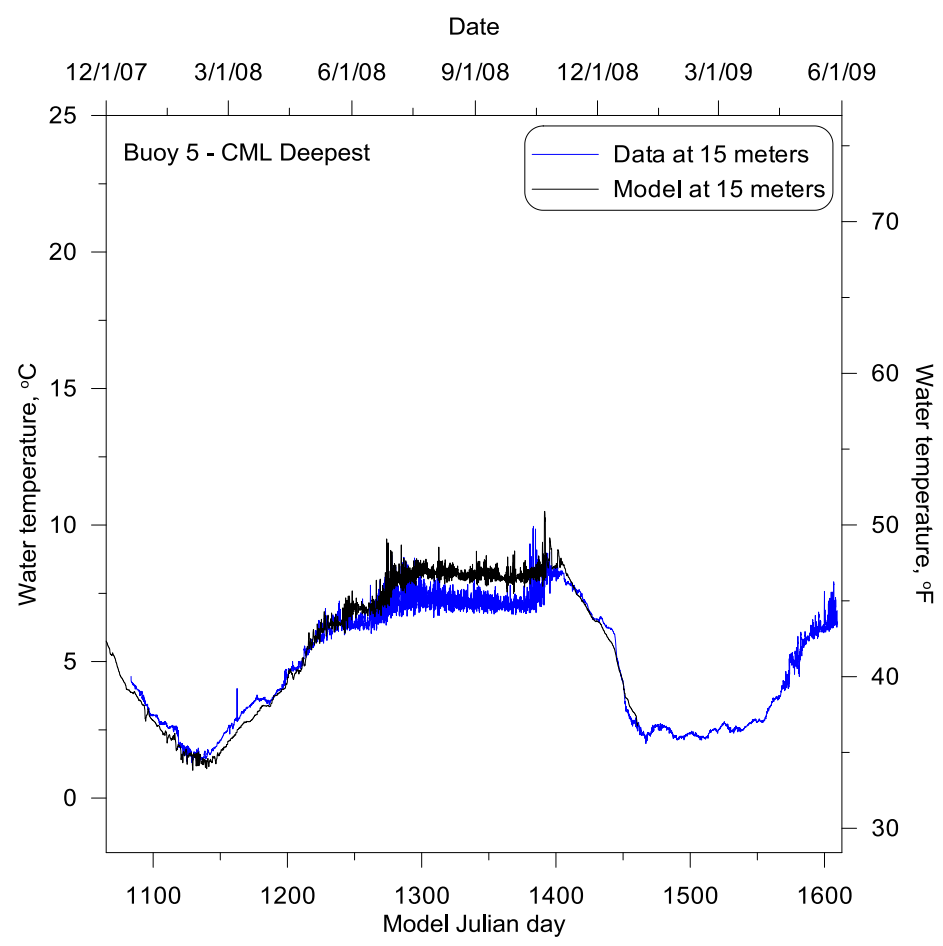

Figure 116. Model vs. data temperature comparison at Buoy 5 (corresponding to model segment 23) CML Deepest - at 15 meters

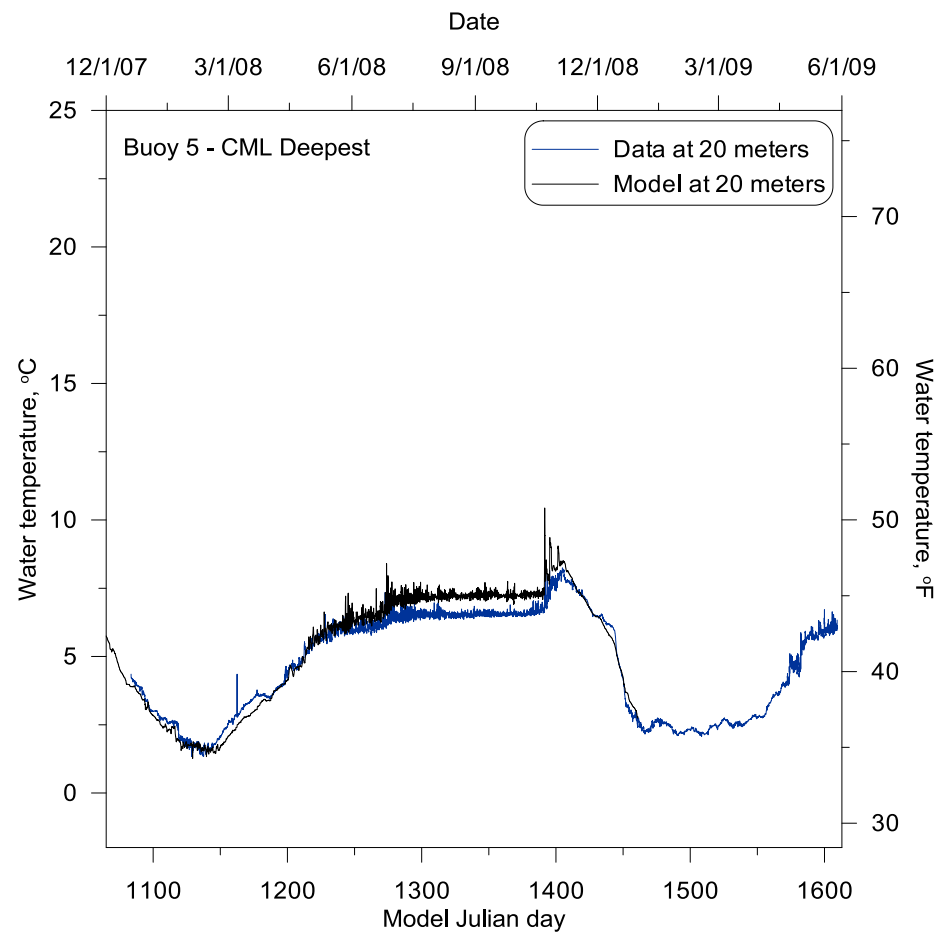

Figure 117. Model vs. data temperature comparison at Buoy 5 (corresponding to model segment 23) CML Deepest - at 20 meters 


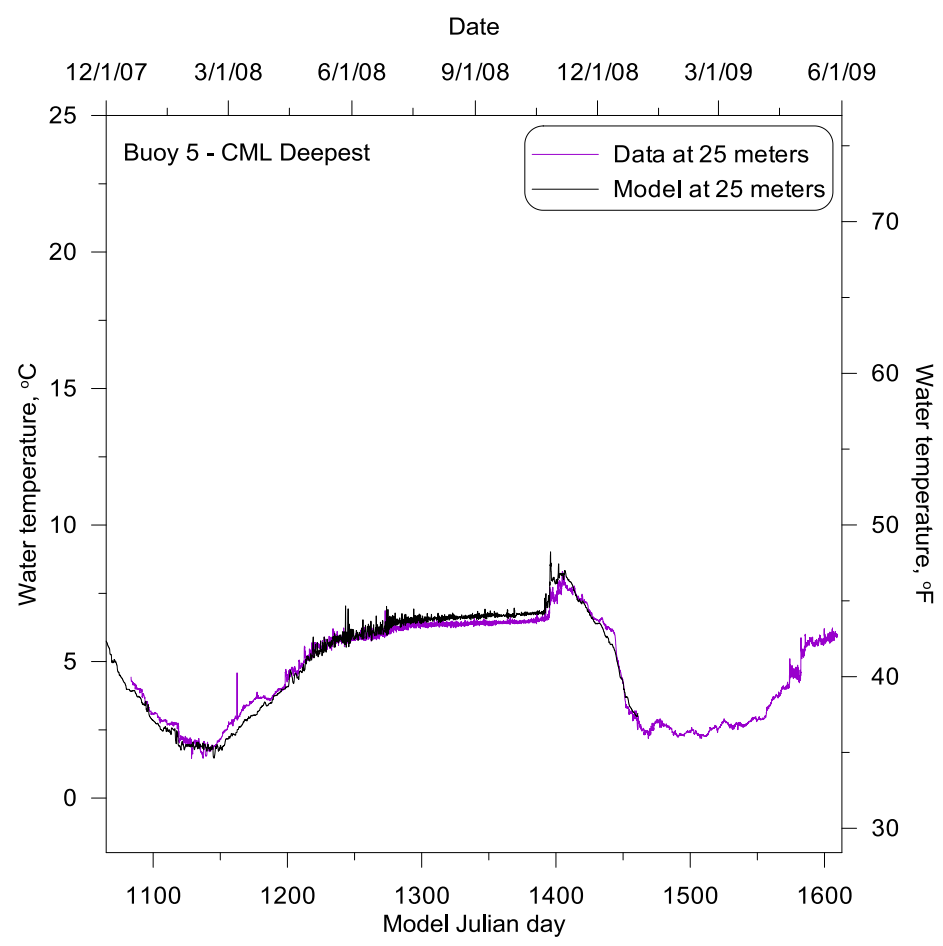

Figure 118. Model vs. data temperature comparison at Buoy 5 (corresponding to model segment 23) CML Deepest - at 25 meters

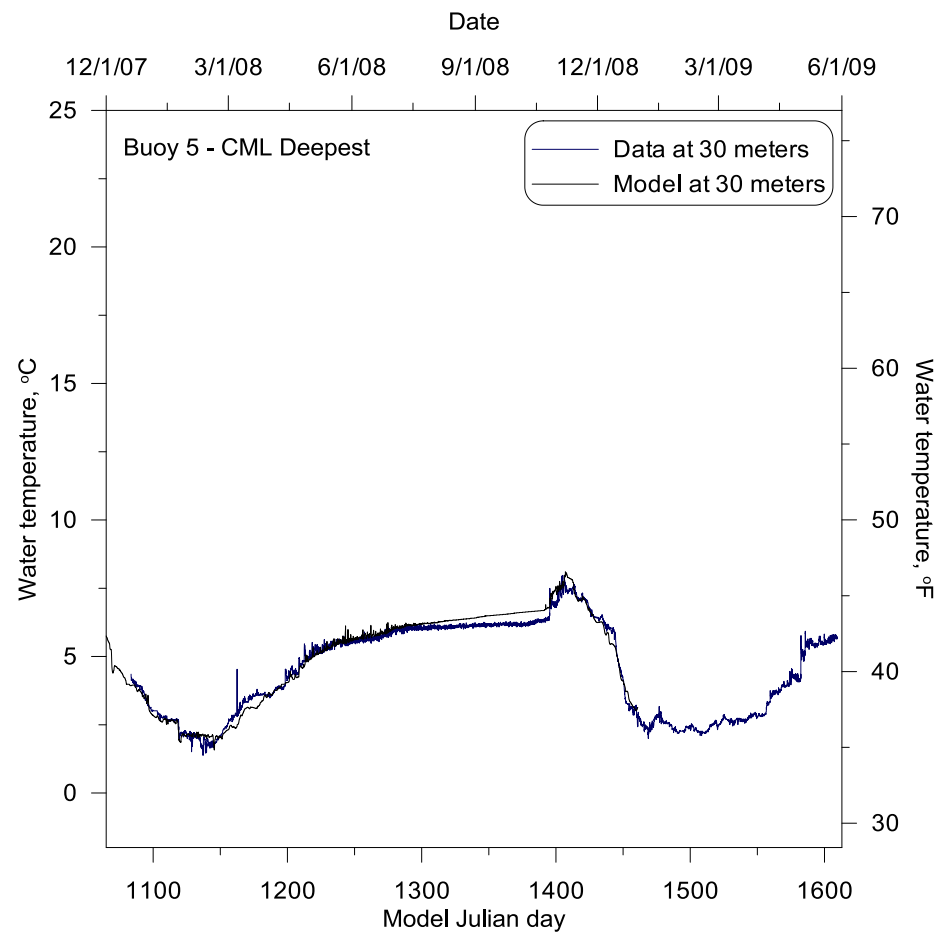

Figure 119. Model vs. data temperature comparison at Buoy 5 (corresponding to model segment 23) CML Deepest - at 30 meters 


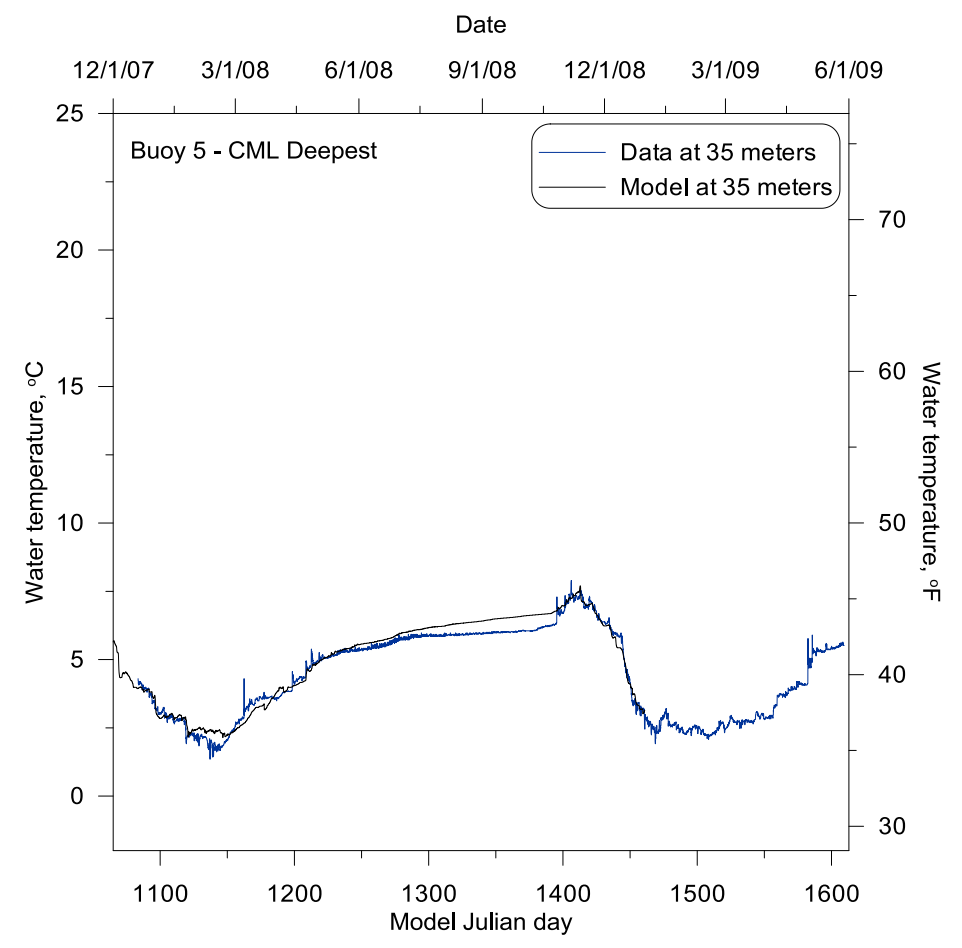

Figure 120. Model vs. data temperature comparison at Buoy 5 (corresponding to model segment 23) CML Deepest - at 35 meters

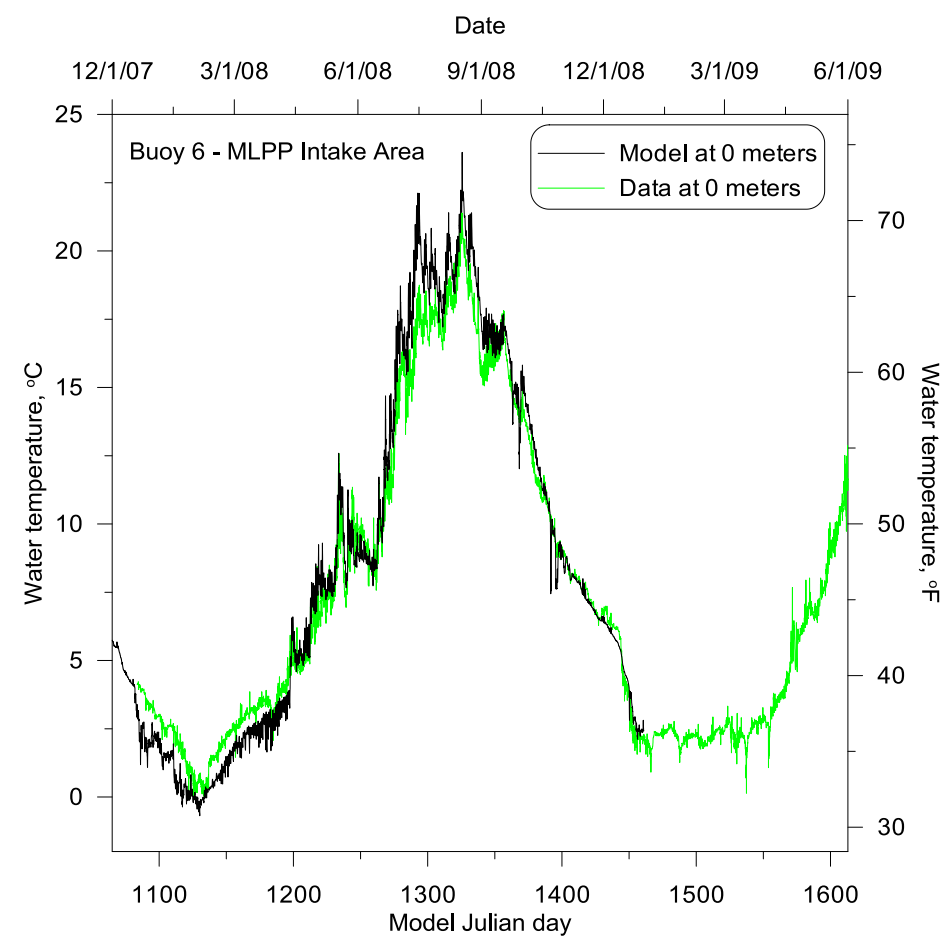

Figure 121. Model vs. data temperature comparison at Buoy 6 (corresponding to model segment 34) MLPP Intake Area - at water surface 


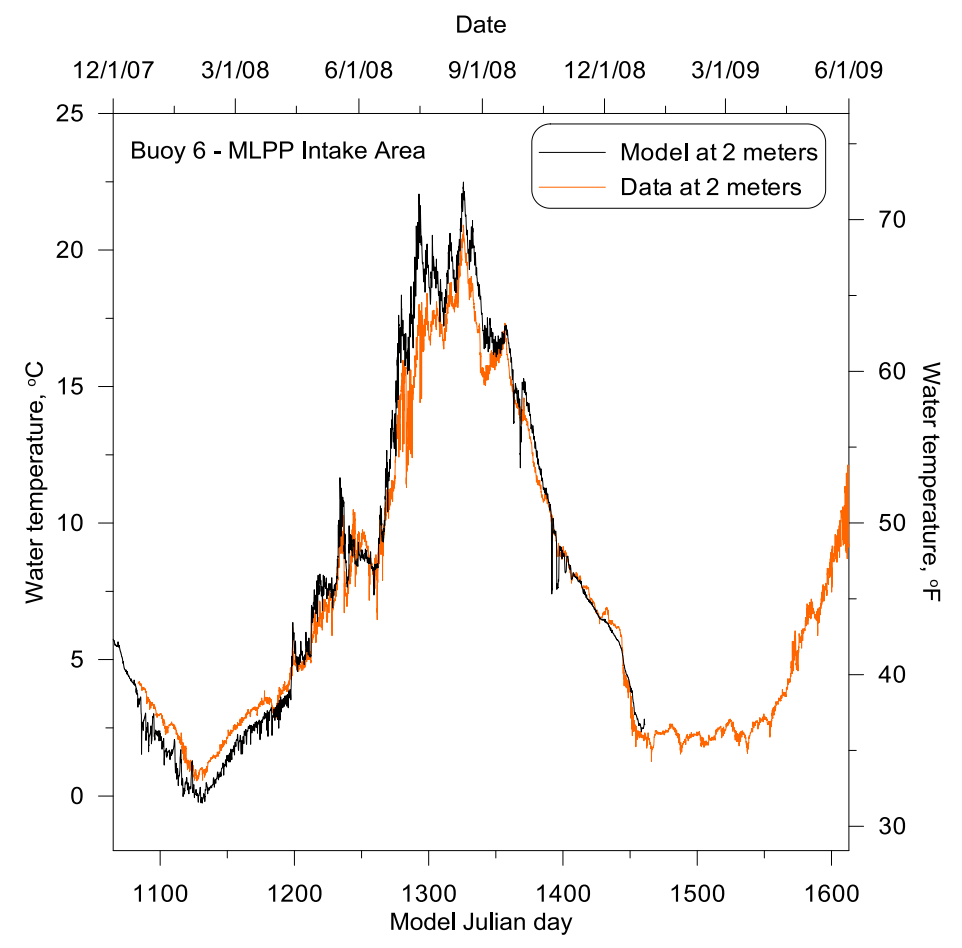

Figure 122. Model vs. data temperature comparison at Buoy 6 (corresponding to model segment 34) MLPP Intake Area - at 2 meter depth

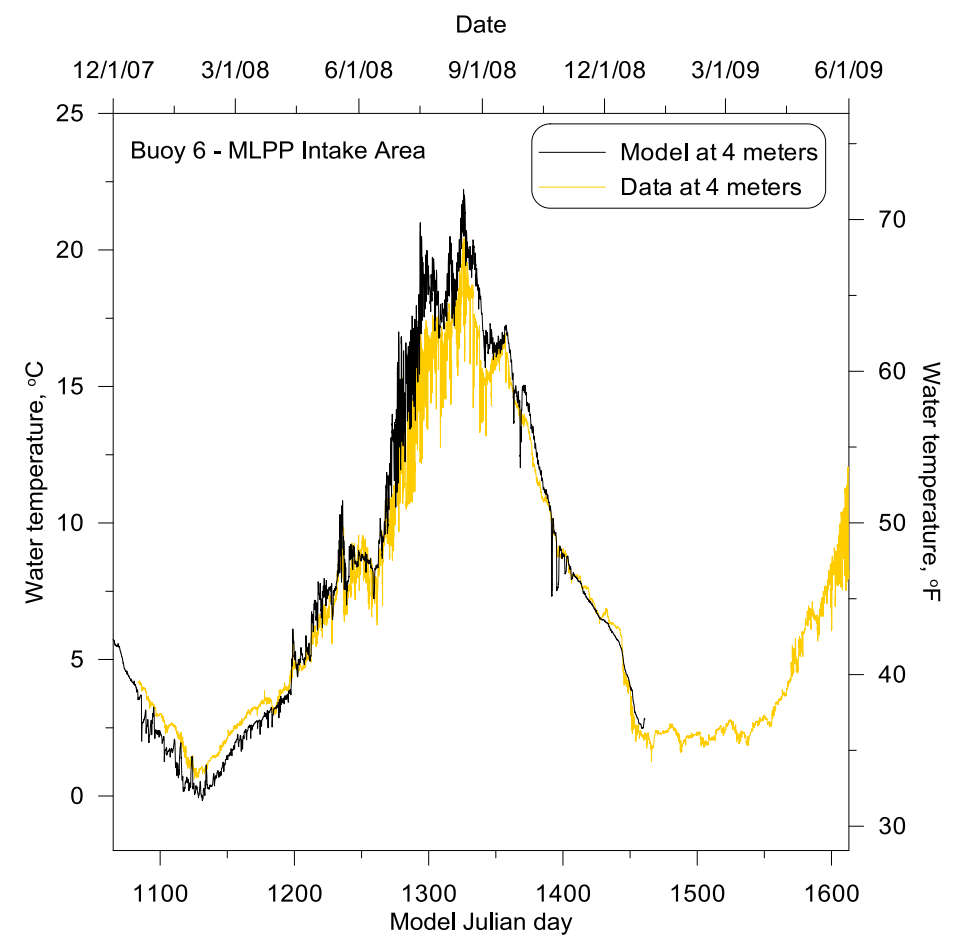

Figure 123. Model vs. data temperature comparison at Buoy 6 (corresponding to model segment 34) MLPP Intake Area - at 4 meter depth 


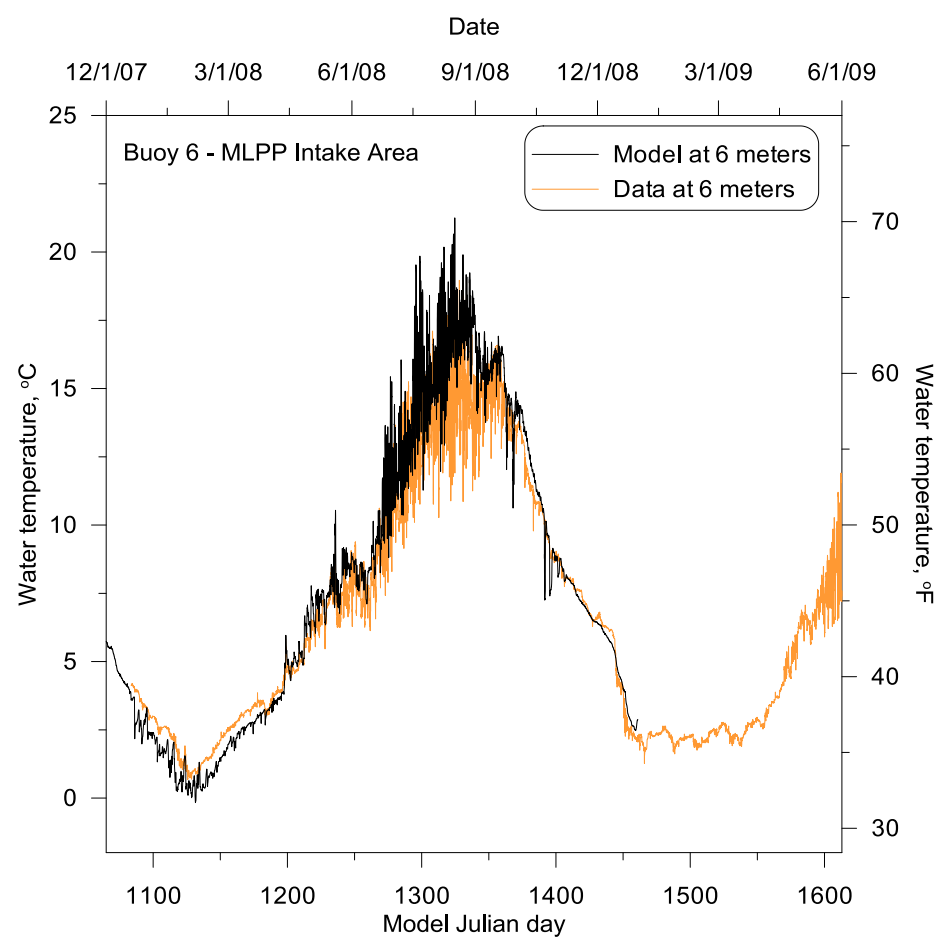

Figure 124. Model vs. data temperature comparison at Buoy 6 (corresponding to model segment 34) MLPP Intake Area - at 6 meter depth

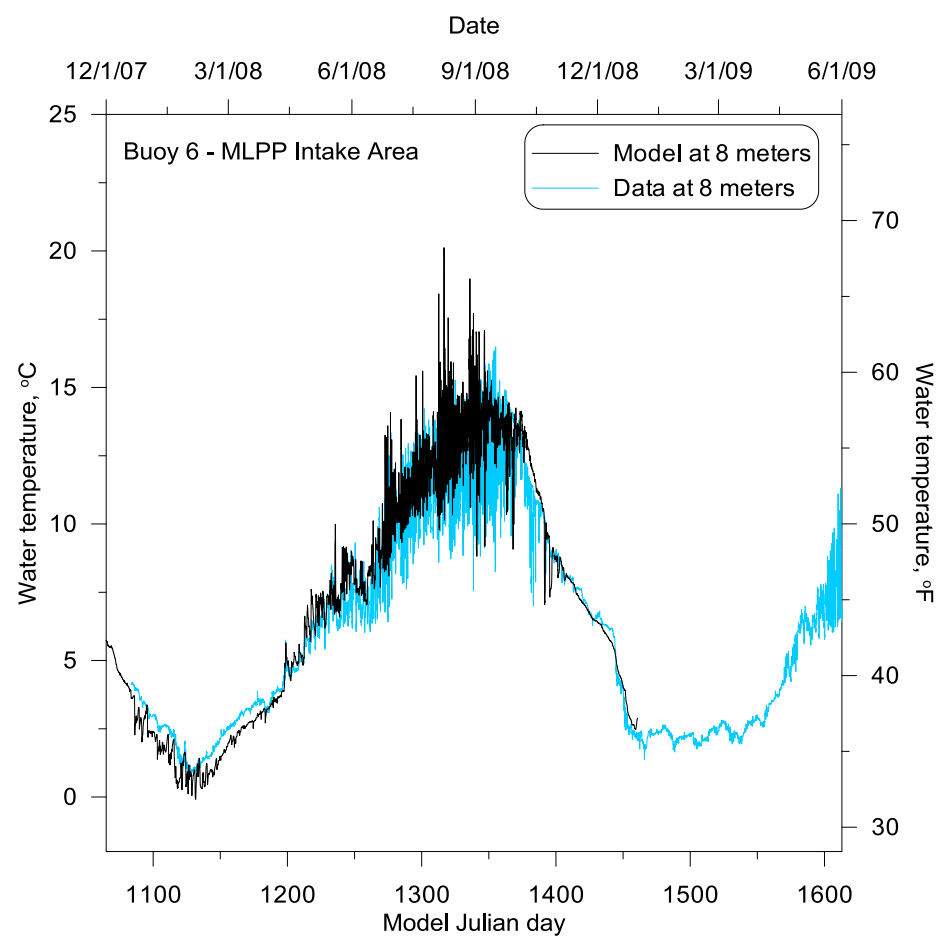

Figure 125. Model vs. data temperature comparison at Buoy 6 (corresponding to model segment 34) MLPP Intake Area - at 8 meter depth 


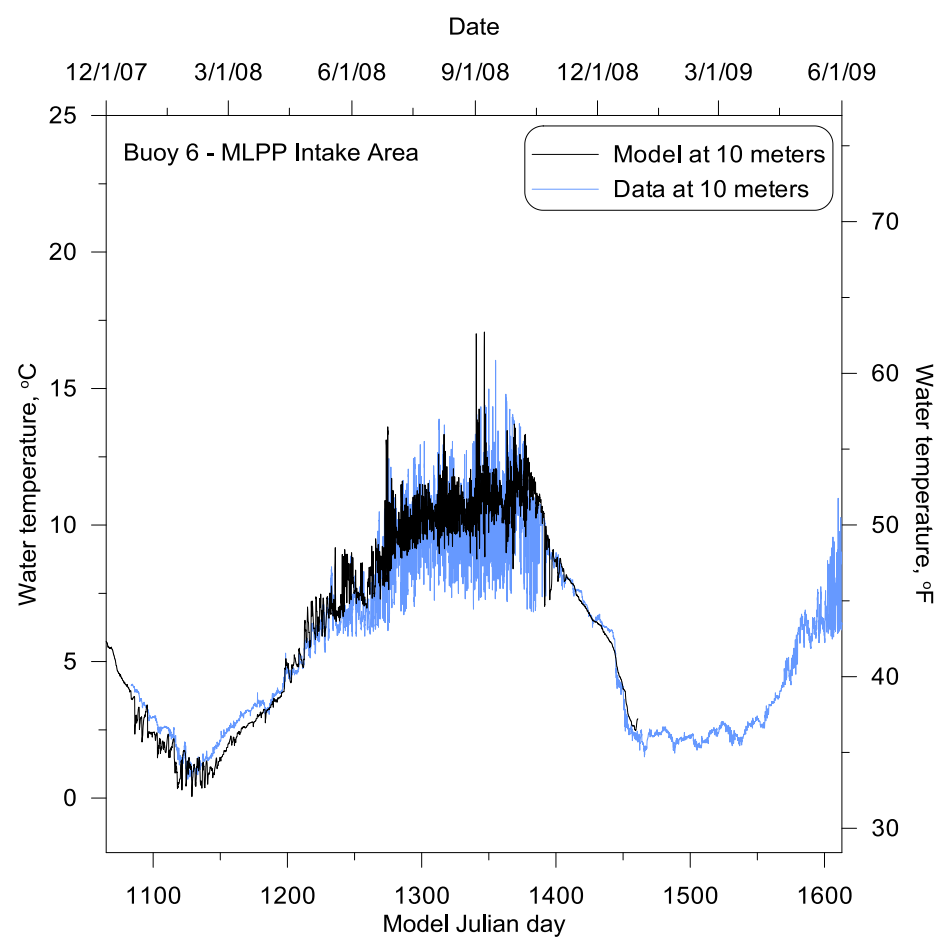

Figure 126. Model vs. data temperature comparison at Buoy 6 (corresponding to model segment 34) MLPP Intake Area - at 10 meter depth

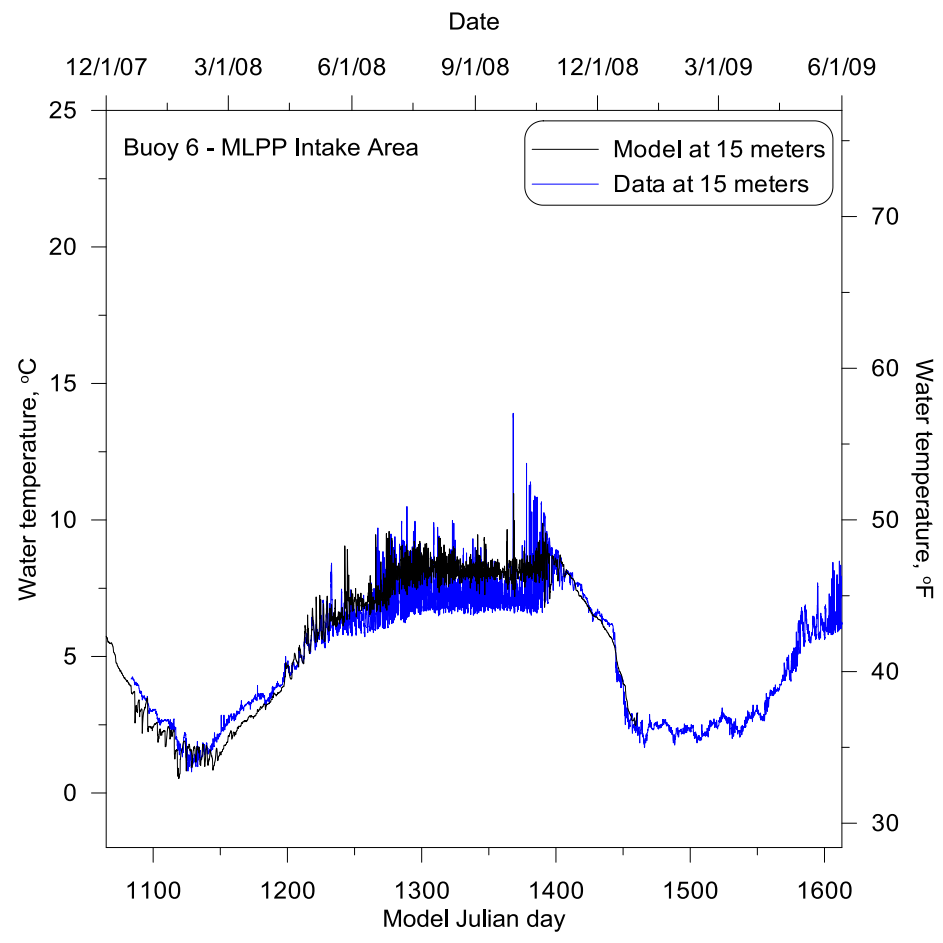

Figure 127. Model vs. data temperature comparison at Buoy 6 (corresponding to model segment 34) MLPP Intake Area - at 15 meter depth 


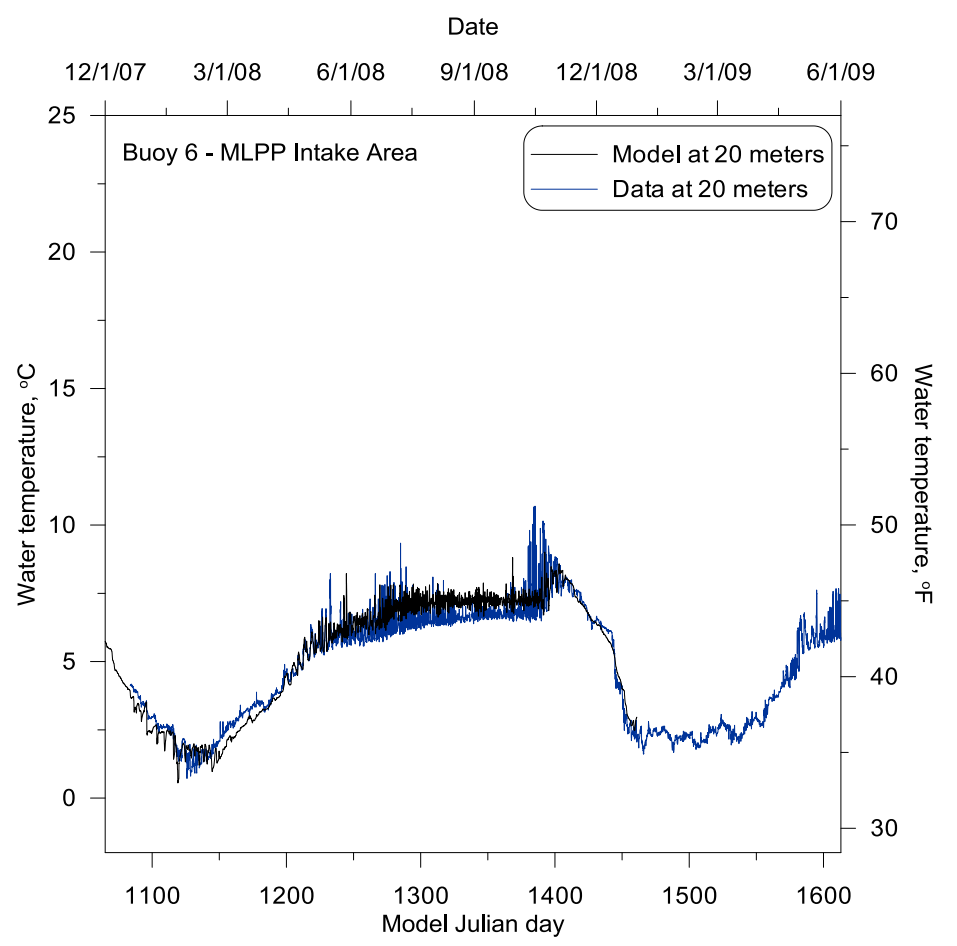

Figure 128. Model vs. data temperature comparison at Buoy 6 (corresponding to model segment 34) MLPP Intake Area - at 20 meter depth

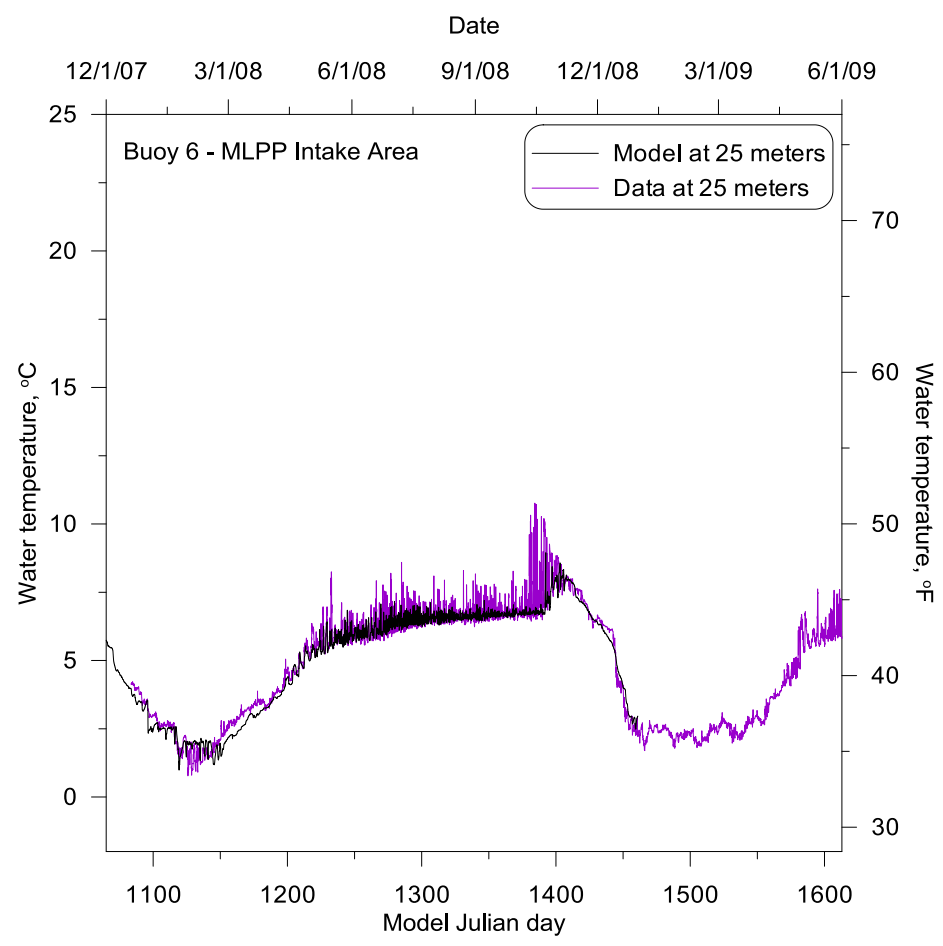

Figure 129. Model vs. data temperature comparison at Buoy 6 (corresponding to model segment 34) MLPP Intake Area - at 25 meter depth 


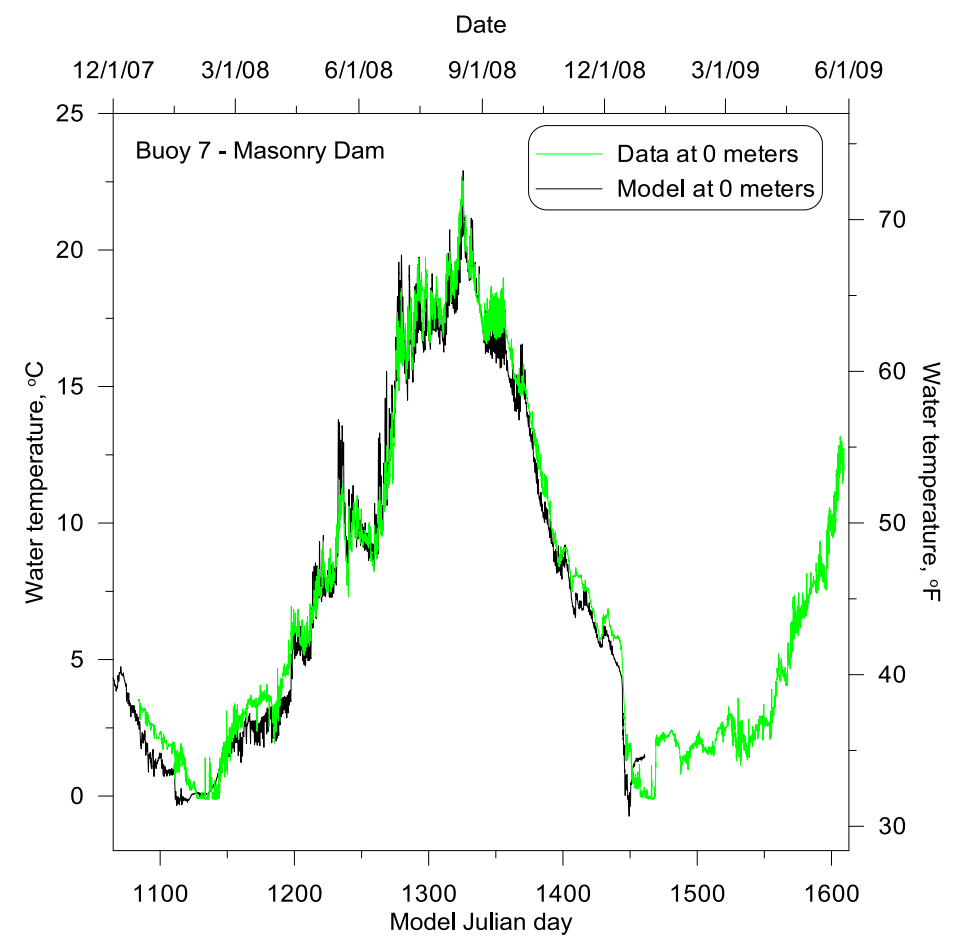

Figure 130. Model vs. data temperature comparison at Buoy 7 (corresponding to model segment 64) Masonry Dam - at water surface

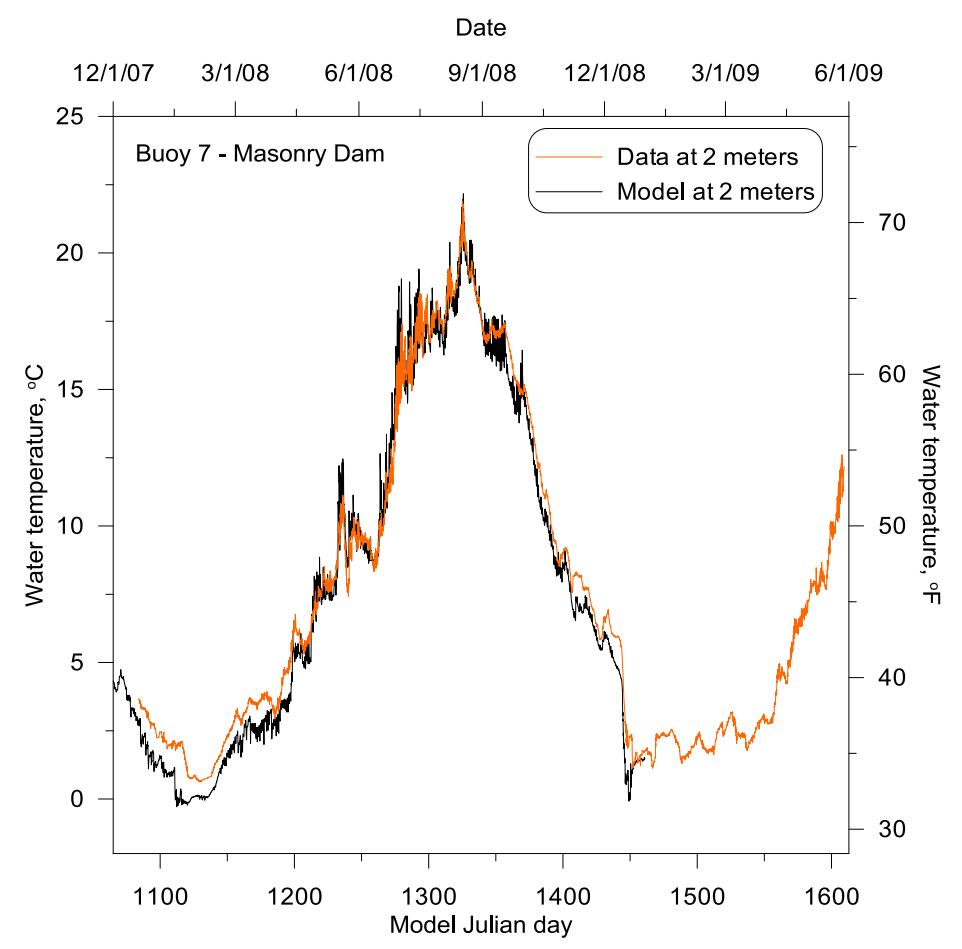

Figure 131. Model vs. data temperature comparison at Buoy 7 (corresponding to model segment 64) Masonry Dam - at 2 meter depth 


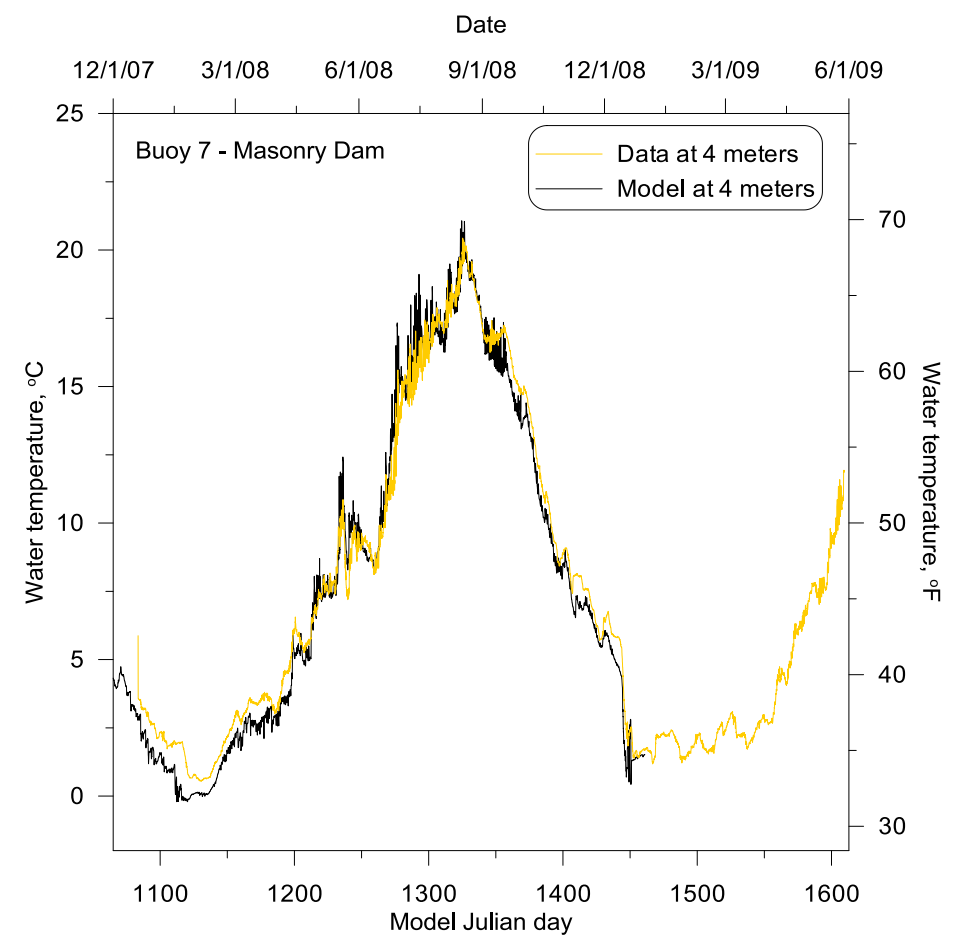

Figure 132. Model vs. data temperature comparison at Buoy 7 (corresponding to model segment 64) Masonry Dam - at 4 meter depth

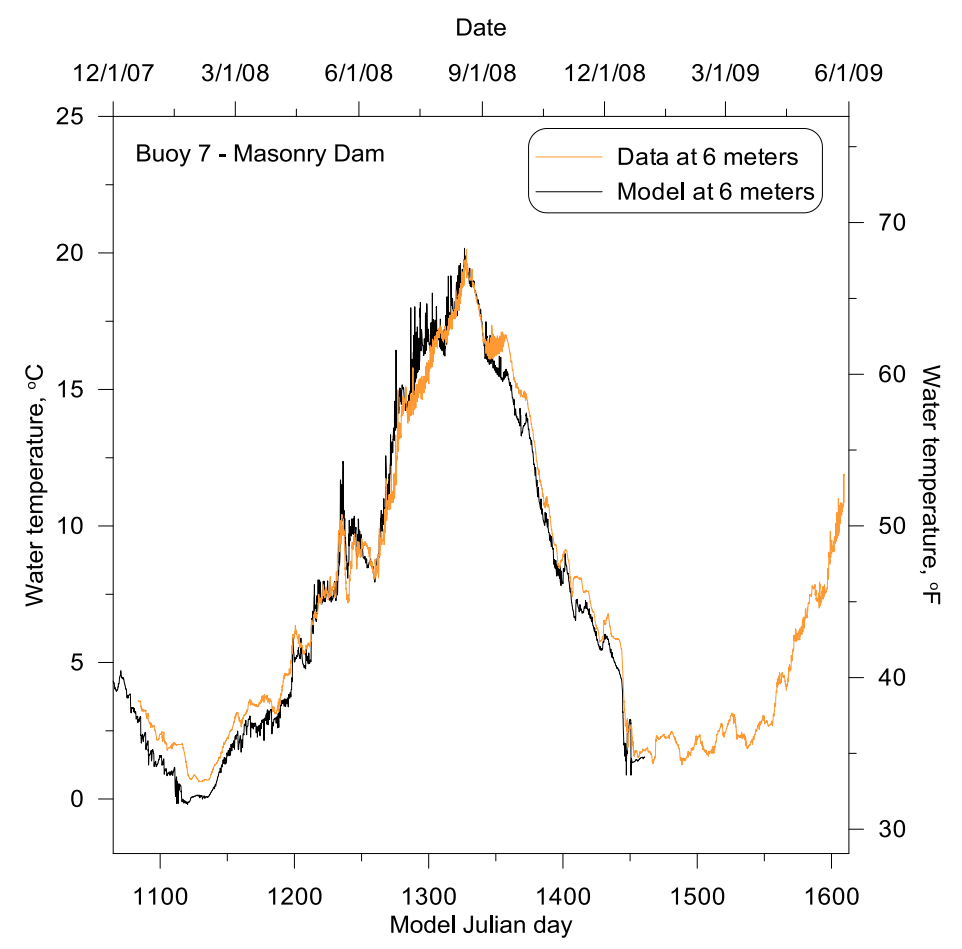

Figure 133. Model vs. data temperature comparison at Buoy 7 (corresponding to model segment 64) Masonry Dam - at 6 meter depth 


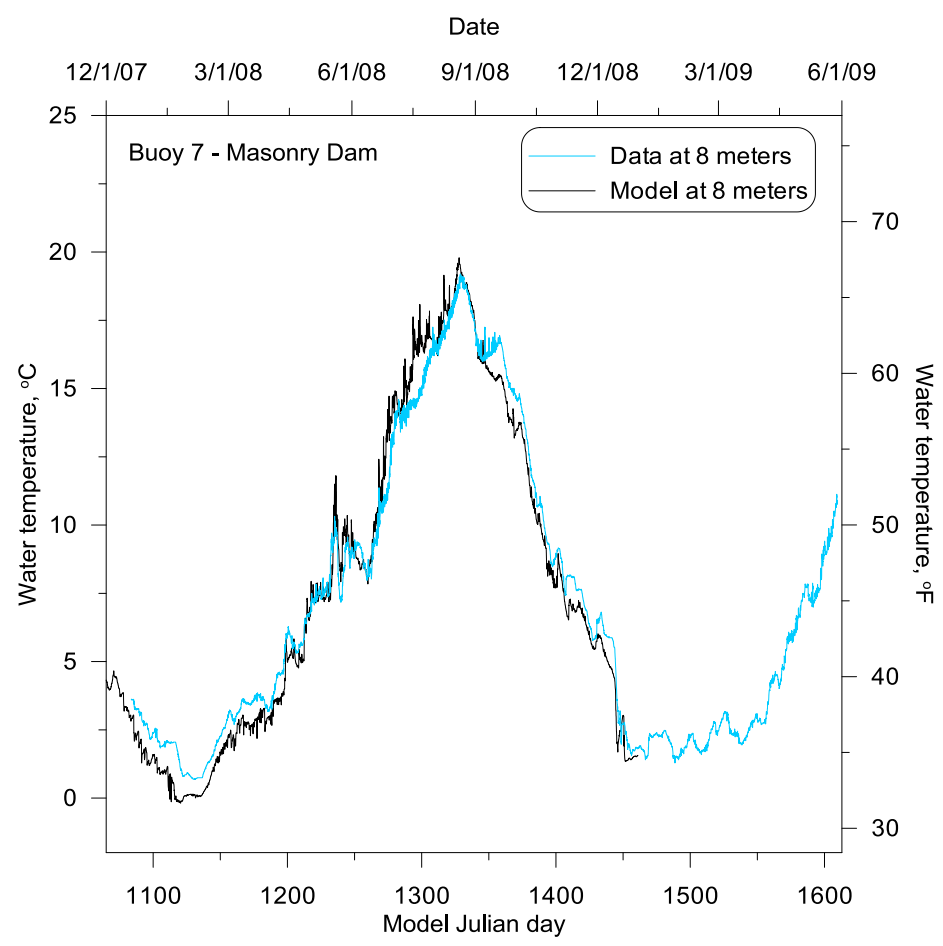

Figure 134. Model vs. data temperature comparison at Buoy 7 (corresponding to model segment 64) Masonry Dam - at 8 meter depth

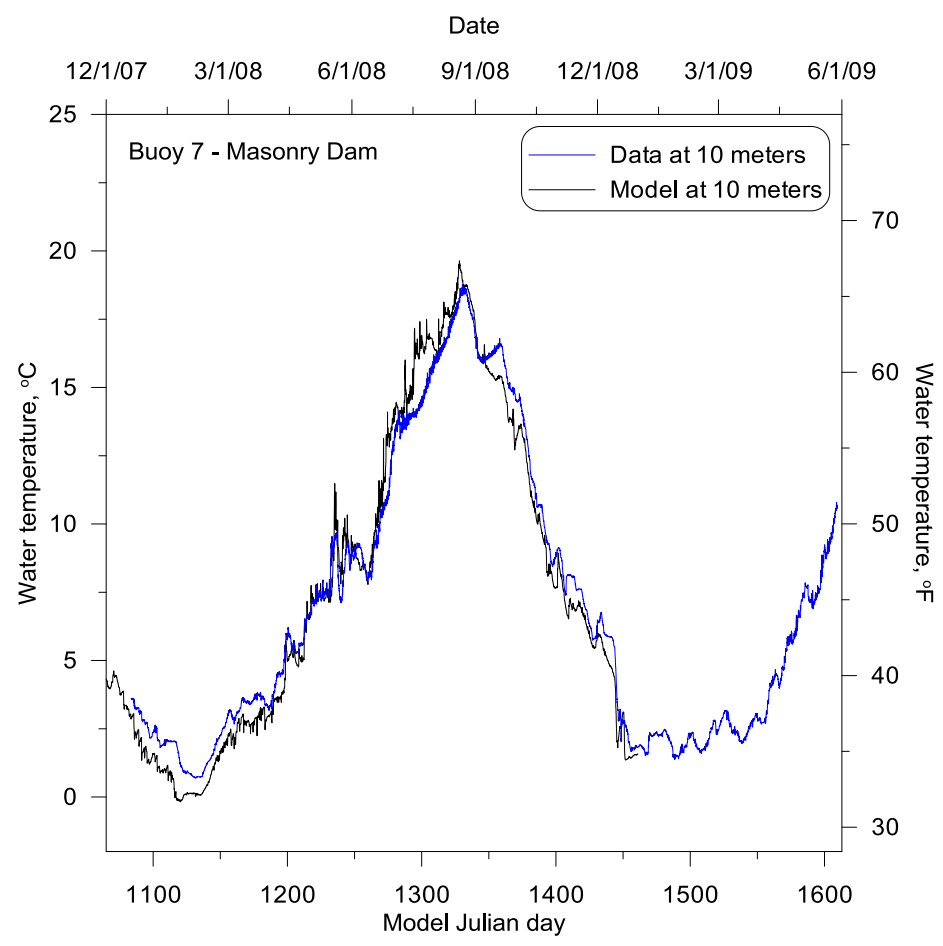

Figure 135. Model vs. data temperature comparison at Buoy 7 (corresponding to model segment 64) Masonry Dam - at 10 meter depth 


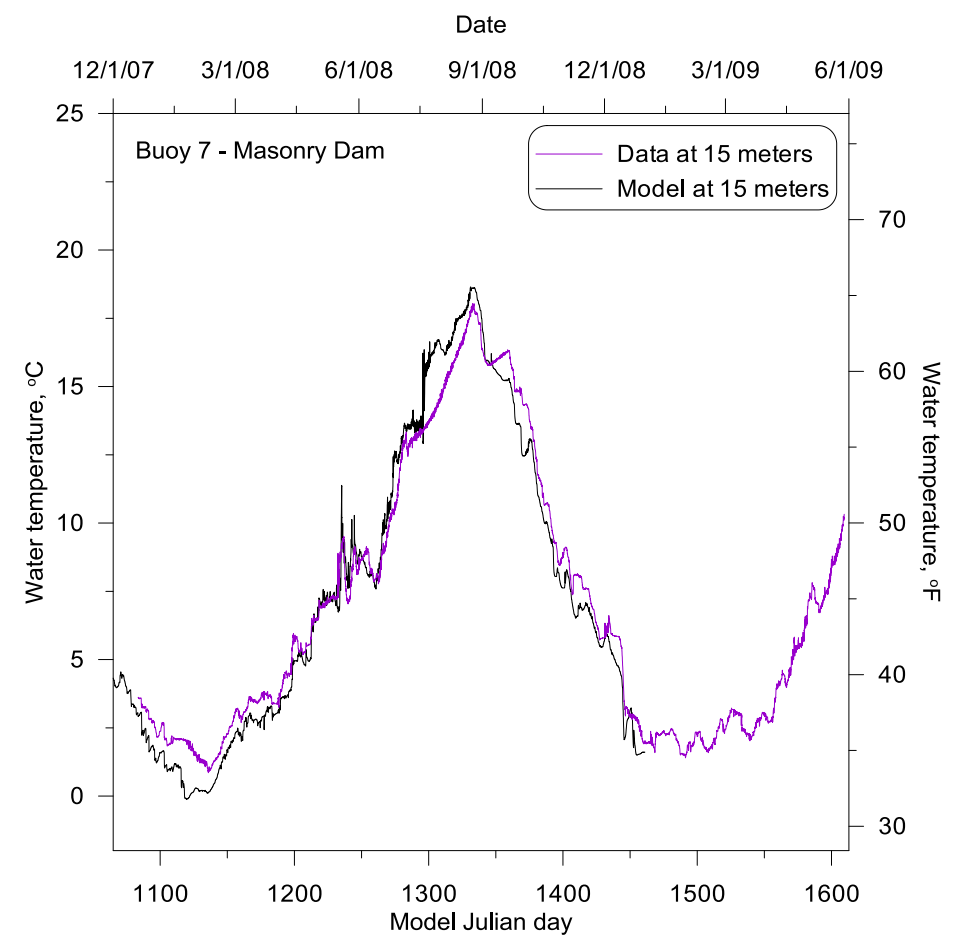

Figure 136. Model vs. data temperature comparison at Buoy 7 (corresponding to model segment 64) Masonry Dam - at 15 meter depth

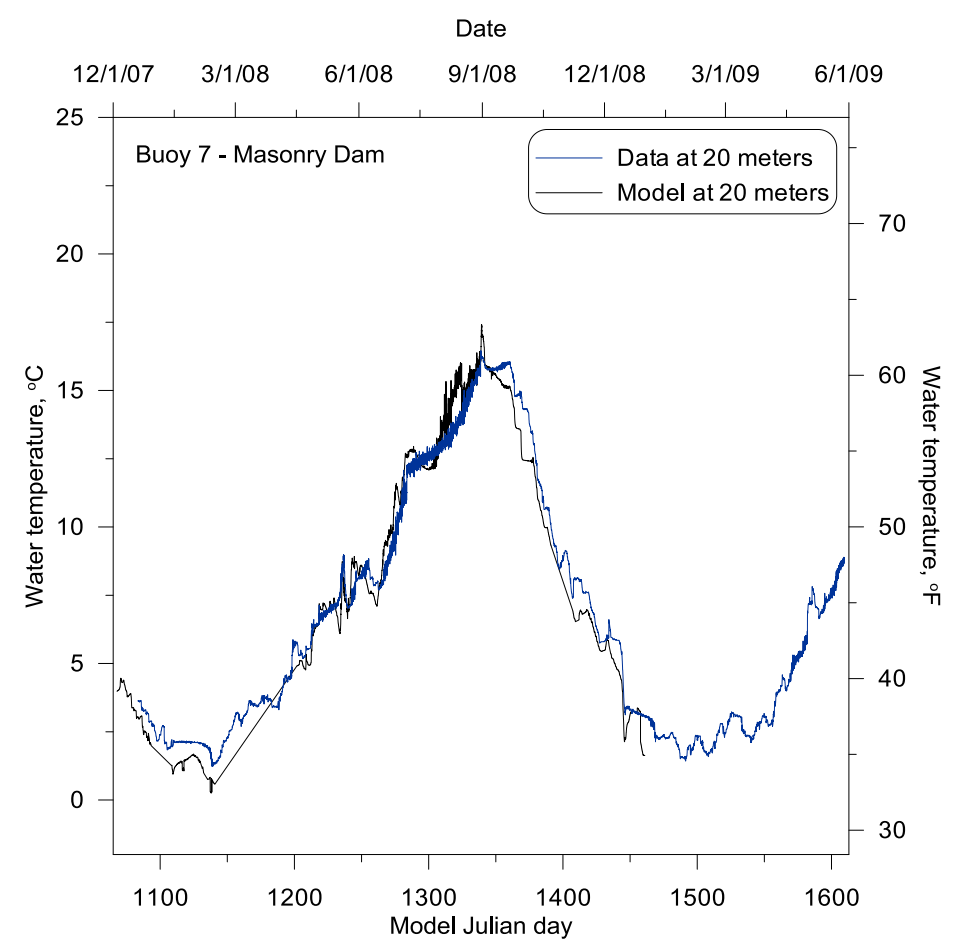

Figure 137. Model vs. data temperature comparison at Buoy 7 (corresponding to model segment 64) Masonry Dam - at 20 meter depth 


\section{Manually Collected Temperature Profile Data}

Temperature profiles were collected on a monthly basis during the calibration period at a set location at approximately the center of the main lake, corresponding with model segment 27. Figure 138 through Figure 143 show the model data comparisons at these locations. Model results are shown as a black line. Measured data at 1 meter intervals are shown as blue triangles.
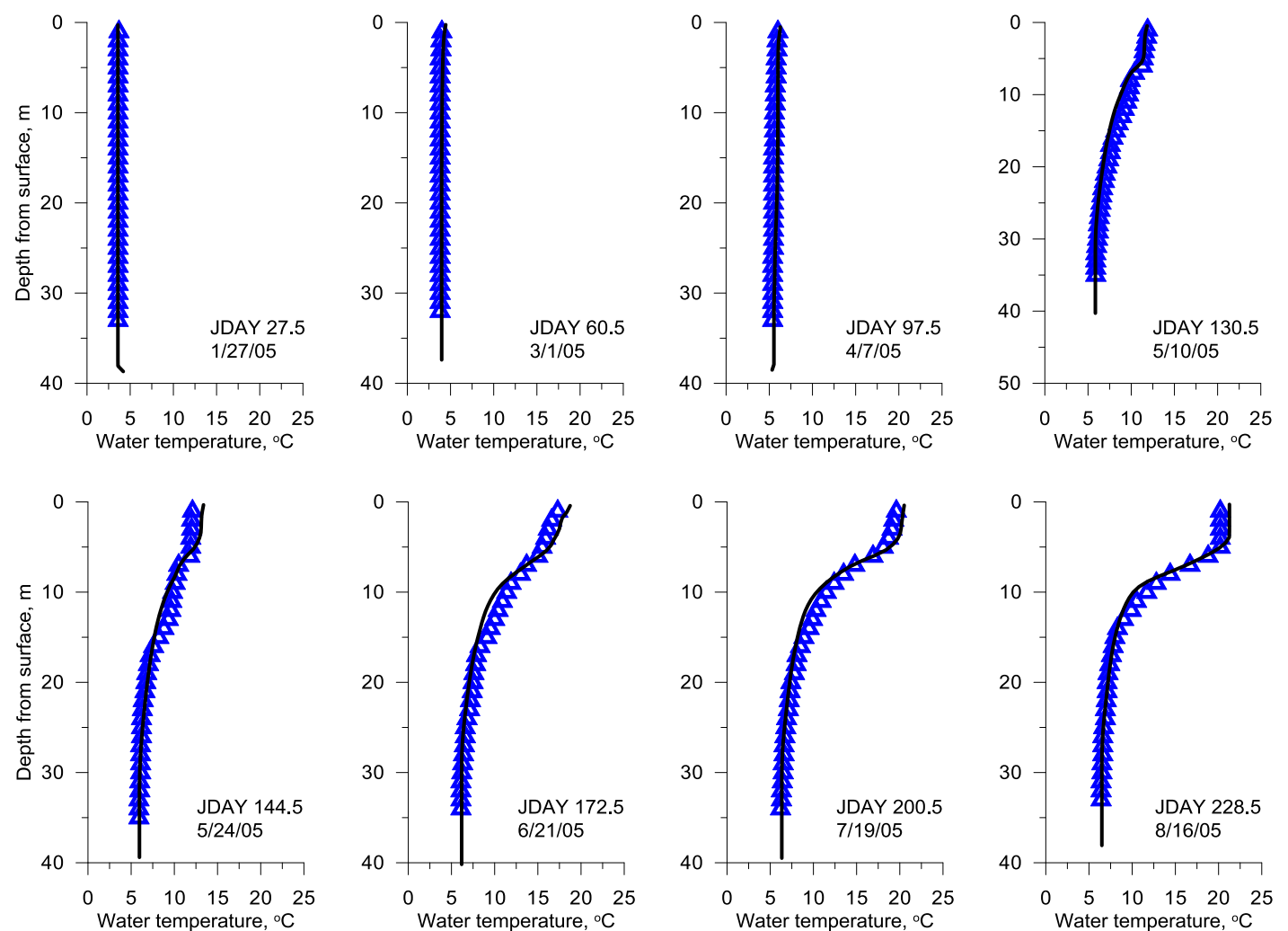

Figure 138. Model vs. data temperature comparison profiles at center of main lake (corresponding to model segment 27) - 1/27/05-8/16/05 

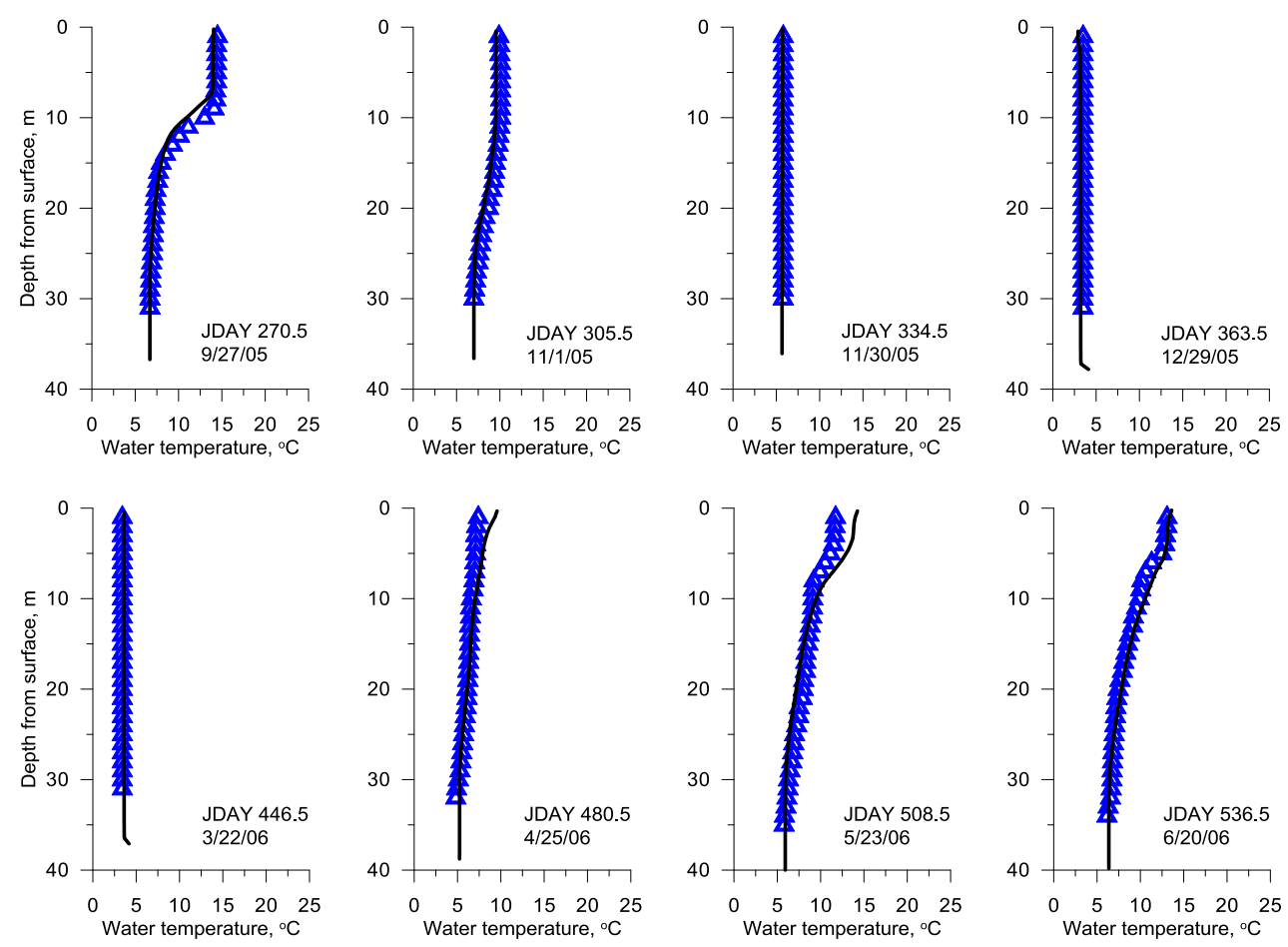

Figure 139. Model vs. data temperature comparison profiles at center of main lake (corresponding to model segment 27) - 9/27/05-6/20/06
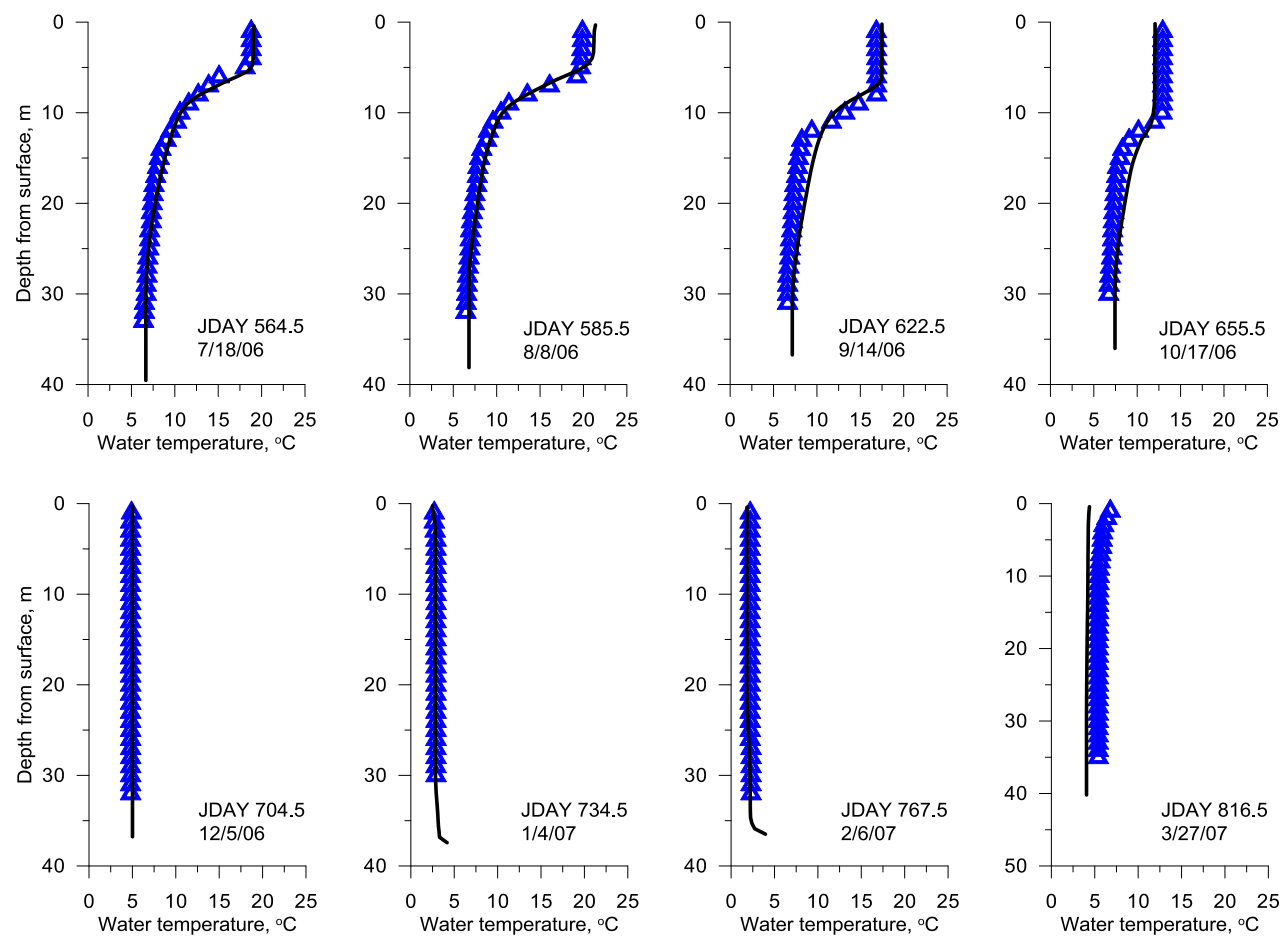

Figure 140. Model vs. data temperature comparison profiles at center of main lake (corresponding to model segment 27) - 7/18/06-3/27/07 

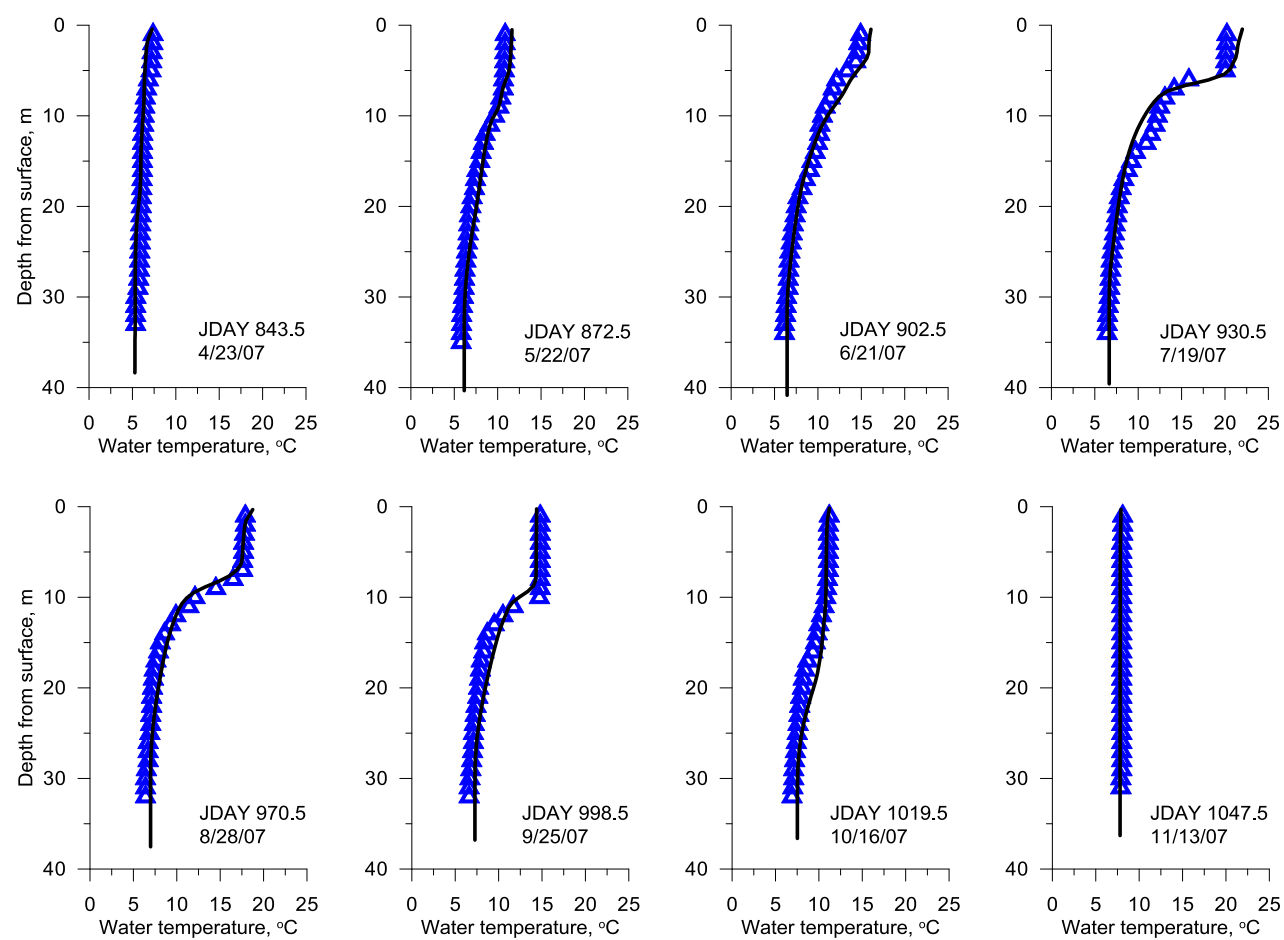

Figure 141. Model vs. data temperature comparison profiles at center of main lake (corresponding to model segment 27) - 4/23/07-11/13/07
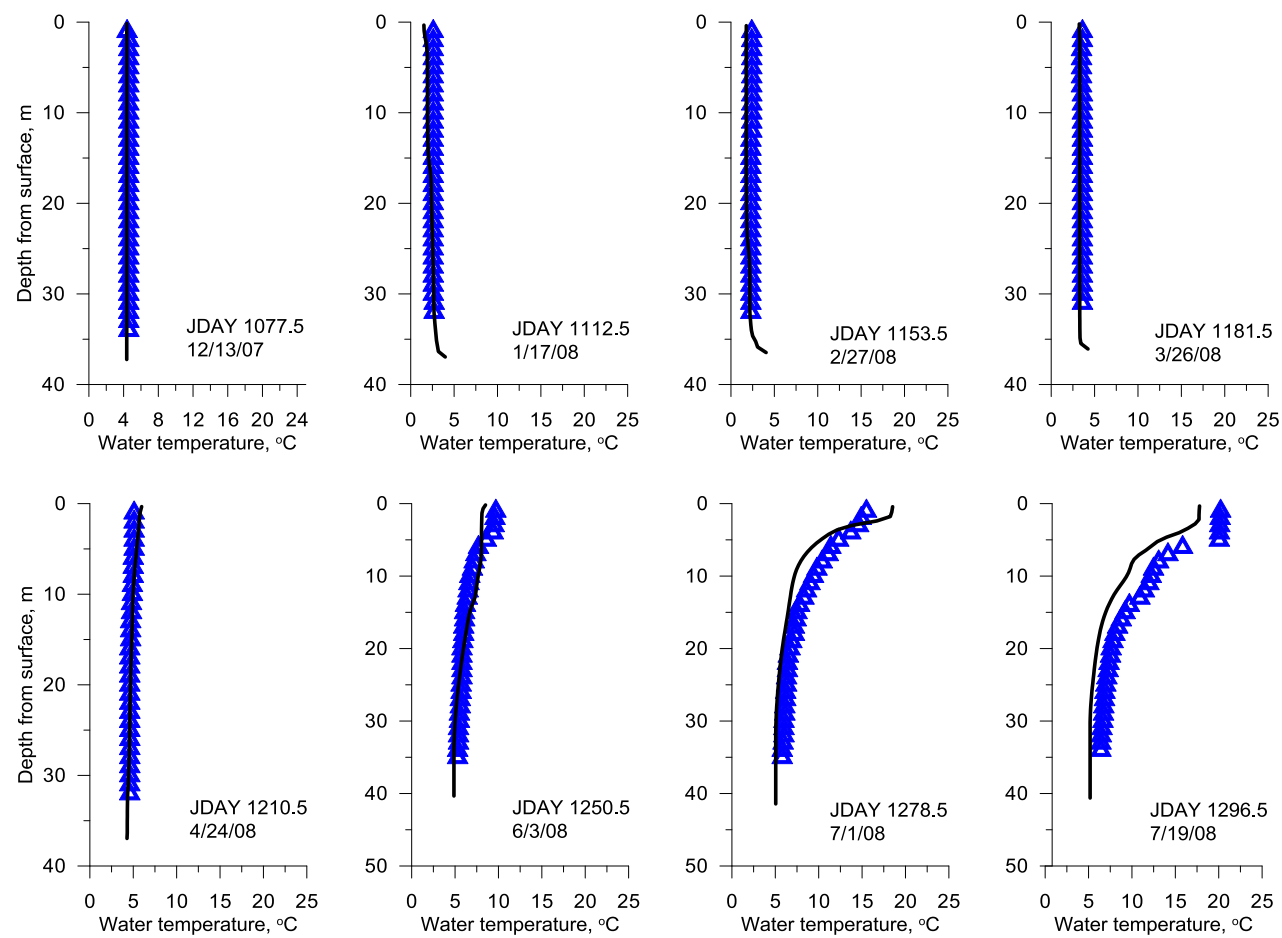

Figure 142. Model vs. data temperature comparison profiles at center of main lake (corresponding to model segment 27) - 12/13/07-7/19/08 

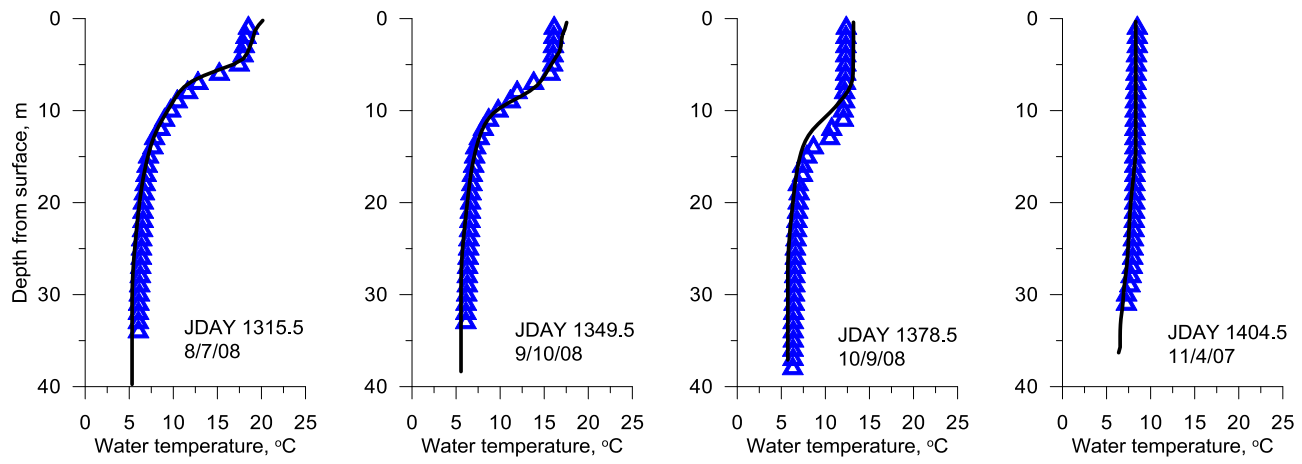

Figure 143. Model vs. data temperature comparison profiles at center of main lake (corresponding to model segment 27$)-8 / 7 / 08-11 / 4 / 08$

Limited temperature profiles were collected in the Masonry Pool near the Masonry dam

(model segment 64) during the calibration period. These profiles are shown in Figure

144.
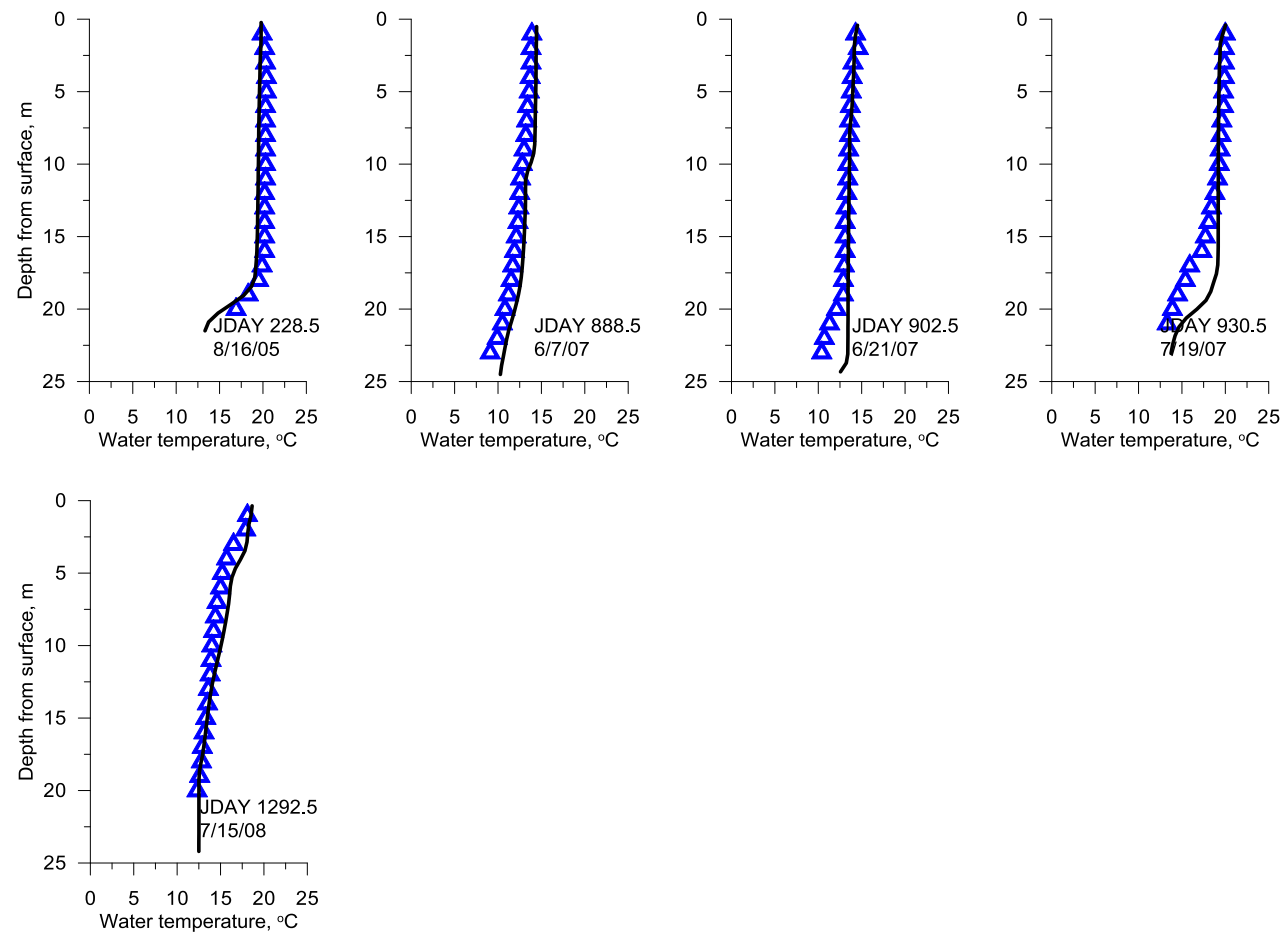

Figure 144. Model vs. data temperature comparison profiles at Masonry Dam (corresponding to model segment 64) - 8/16/05-7/15/08 